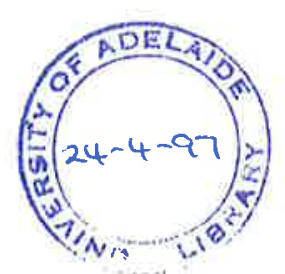

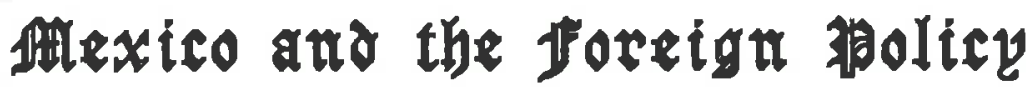 \\ of \\ IRapoleot IIJ
}

\section{Michele Cunningham}

Thesis presented as requirement for the degree of Doctor of Philosophy in the Department of History, University of Adelaide 


\section{Couteuts}

Abstract

iii

Statement

iv

Acknowledgements

$v$

Abbreviations

$v i$

Introduction

1

Chapter 1 Calls for Intervention

20

Chapter 2 Aims of the Intervention

51

Chapter 3 The Venture Underway

72

Chapter 4 A Life of its Own

96

Chapter 5 Our Honour Engaged

136

Chapter 6 Duplicity Revealed

163

Chapter 7 The Empire Does Mean Peace

190

Chapter 8 La Grande Pensée de la Règne?

Conclusion

257

Bibliography

268

Index of Names

277 


\section{abstraet}

The French intervention in Mexico between 1862 and 1867, undertaken initially in conjunction with England and Spain, has challenged historians, as it did contemporaries, who have sought to understand and explain why Napoleon became involved in what many saw as a hopeless cause. A number of conclusions have been reached, ranging from France's need to find resources such as silver and cotton, to Napoleon's determination to establish a Latin, Catholic, monarchical bloc to the further encroachment of the United States into Central and South America. While each of these theories contains an element of truth, they can be challenged because the analyses have not gone far enough. Many historians have seen the imposing of a Latin Catholic bloc as "the grand idea" (la grande pensée) of the Emperor, some claiming it failed because of the ineptitude of its author, and others because Napoleon was a Utopian dreamer out of touch with reality. But such an act would have been contrary to his policy.

No one previously has attempted to ascertain whether there is some thread of consistency between Napoleon's approach to the Mexican question and to other foreign issues during his reign. This thesis seeks to redress that gap in the historiography by analysing the basis of Napoleon's foreign policy, and by placing the Mexican venture within the context of that policy. Developed from the political writings of his youth, his policy will be seen to embrace a world view that few of his contemporaries were able to comprehend or appreciate until after his death. In the case of his foreign contemporaries, their views were always tinged with fear and suspicion that he intended to subjugate Europe as his uncle had done. Neither have historians accepted his world view in the spirit in which it was intended, which was to establish a basis for peace. Instead, many have dismissed it as the ruminations of a dreamer. Napoleon's policy towards Mexico was consistent with his policy in Europe, and the significance of this conclusion is that it shows, despite claims to the contrary, that he did have a foreign policy, and was not merely the naïve opportunist his critics saw him to be. 
This work contains no material which has been accepted for the award of any other degree or diploma in any university or other tertiary institution and, to the best of my knowledge and belief, contains no material previously published or written by another person, except where due reference has been made in the text.

I give consent to this copy of my thesis, when deposited in the University Library, being available for loan and photocopying. 


\section{Giknowlergemetrts}

I owe my love of French history to Austin Gough, who led me into the wonderful and fascinating world of research with his own enthusiasm and talent for making history come alive. I had no idea it would lead me very shortly into the archives of Paris and London in an endeavour to understand the world of the enigmatic Napoleon III. I thank him also for reading and offering valuable comments on the product of my research. Vesna Drapac has guided me unerringly through numerous drafts of this thesis, and her ability to keep me in touch with the wider picture has been invaluable, as has her talent for seeing the significance of material with which, on occasion, I had become too familiar to appreciate.

My fascination with the Second Empire was inspired by the writings of a contemporary journalist and former diplomat, Grenville Murray. His satirical writings on many aspects of the Empire encouraged me to determine whether or not there was any substance to Napoleon III and his Empire. I feel my studies have hardly begun. One of the interesting aspects of Murray's writings is that his later articles move from undisguised ridicule of the Emperor to a very warm acceptance of the man and his work for France. I cannot help but feel this change occurred after he went to live in France in 1868 and perhaps met the Emperor himself. A chance discovery in the Archives Nationales of a letter from Murray to the Empress Eugenie confirmed that view. Murray wrote a week before the defeat at Sedan expressing his admiration for the Emperor and all he had tried to achieve, and offered his assistance in enlighteneing the English public in the face of anti-French propaganda disseminated by the Prussians. His opinion of the Emperor was one of many that encouraged me to persist in the belief that Napoleon III was more honest in his intentions than his many critics have given him credit for, and that his memory has been sullied by the proliferation of history that was written by his opponents in the period of the Third Republic.

I am extremely grateful for the assistance I received from staff in the French archives particularly. In the Archives Nationales I was directed to sources of which I had been unaware, and the guidance afforded to me both in the archives and by correspondence is appreciated. Similarly, the staff in the Service Historique de l'Armée de Terre at Vincennes, and in the Archives du Ministère des Affaires Étrangères made my limited time there very productive. Most importantly, without the support of my husband, John, I would never have been able to do this. I will be forever grateful to him, Shane, Alison and David for allowing me to spend several weeks in Europe without them. 


\section{ltst of Ebbrevtations}

$\begin{array}{ll}\text { A.D. } & \text { Archives Diplomatiques } \\ \text { AMAE } & \text { Archives du Ministère des Affaires Étrangères } \\ \text { AMG } & \text { Archives du Ministre de la Guerre } \\ \text { AN } & \text { Archives Nationales } \\ \text { AP } & \text { Archives privées } \\ \text { CP } & \text { Correspondance politique } \\ \text { FO } & \text { Foreign Office } \\ \text { PA-AP } & \text { Papiers d'agents-archives privées } \\ \text { PRO } & \text { Public Record Office } \\ \text { R.D.M. } & \text { Revue des Deux Mondes } \\ \text { SHAT } & \text { Service Historique de l'Armée de Terre } \\ \text { State Papers } & \text { British and Foreign State Papers }\end{array}$




\section{yntroduction}

In 1861, after many years of unsatisfactory relations with Mexico, France, England and Spain became involved in Mexico with a view to achieving stability in that strife-torn country. This campaign was a failure. Behind that failure, however, lies a complex web of historical interests, international rivalries, vested interests, and conflicting ideological bases for the foreign policies of the nations concerned with the attainment of political stability in Mexico. These nations included, most importantly, France, England and the United States and, to a lesser degree, Spain. It is the interests and concerns of these nations that form the background to one of the most controversial episodes of the midnineteenth century. The turmoils that had wracked Europe in the early years of the century culminated in the overthrow of Napoleon I and the "settlement" of Europe by the Treaties of 1815 . These treaties were concluded primarily to prevent a recurrence of the domination of Europe by a single nation, notably France, but effectively weakened most of the Powers in Europe. The effects of both the years of war and the settlement were also felt in the Spanish American colonies, which began to revolt against their weakened Spanish masters and demand independence. Mexico, Spain's largest colony, gained its independence in 1821 , but this was only the beginning of a period of revolution and anarchy that was to devastate the country for more than forty years. In addition, an independent Mexico then began to assume a position of strategic and commercial importance to England, the United States and Europe, becoming a pawn, so to speak, in their challenges for supremacy in the region.

The British had shown interest in Mexico ever since Napoleon's Continental System had excluded them from European markets, and Mexico's independence from Spain had encouraged an aggressive commercial interest in the area. As England was still diplomatically isolated from Europe it wished to protect the newly independent Latin American markets from interference by European governments, and proposed to the United States that their two governments sign an agreement "to prevent any European 
intervention in the Western Hemisphere."l The United States, however, decided to issue an independent statement, which became known as the Monroe Doctrine, which had more far-reaching effects than the British proposal. It stated, in part:

(1) That the United States did not wish to take part in the politics or wars of Europe.

(2) That the United States would regard as manifestations of an unfriendly disposition to itself the effort of any European power to interfere with the political system of the American Continents, or to acquire any new territory on these continents. ${ }^{2}$

By this statement the United States were announcing: their determination to protect the republican American nations from conservative European influence; their refusal to allow Latin America to become a protectorate of Great Britain; and that the United States were becoming "a power among nations that had to be reckoned with". 3 So instead of improving its position in the Americas, England was made aware that even its own navigational rights and colonies in the American sphere were under threat, and the United States worked desperately in the following years to reduce England's influence.

The United States at this time were still in a period of great expansion, and determined to possess a large part of the Continent, particularly as far as the west coast, which to this point was controlled by England with its Canadian Provinces and the territory of Oregon, and by Mexico, which owned California. They were also anxious to possess Texas, which had been populated by settlers from the United States when Mexico became independent. Texas itself became independent in 1836, but in 1845 it was annexed by the United States under the expansionist policy of President James Polk. This policy also saw Polk threaten war with England over the territory of Oregon, but England acquiesced to his demands in order to protect its trading interests with the United States and reduce the burden of its colonies. By this step the United States had gained access to the Pacific seaboard, but did not yet possess the only reasonable port, San

\footnotetext{
${ }^{1}$ G.M. Poulton, Great Britain and the Intervention in Mexico 1861-1865. Ph.D. Dissertation, Miami University, 1976 (Michigan, 1982), pp. 12-13.

2William H. Goetzmann, When the Eagle Screamed: The Romantic Horizon in American Diplomacy $1800-1860$ (New York, 1966), pp. 19-20.

3 Ibid.
} 
Francisco. This could only be achieved by taking California from Mexico, and Mexico conveniently declared war on the United States in 1846 over the annexing of Texas. The war lasted two years and resulted in the defeat of Mexico and the ceding of California to the United States in 1848. In three years the area of the United States had been nearly doubled, and continental security almost achieved with possession of the west coast and a valuable port, and removal of a threat to their southern flank through Texas.

Despite England's acquiescence over the Oregon territories, the United States harboured an intense concern over Britain's possible strategic control of a Central American communication route. Britain possessed several islands in the Caribbean as well as having a protectorate along the Mosquito coast of the Honduras and Nicaragua, and if it acquired Cuba from Spain it would control the Caribbean and the approaches to Central America. Britain could, by "asserting its existing control of the high seas ... render California as useless as it had been under Mexico - forcing California and parts of the West to break off from the Union in their own best interests." 4 In a bid to prevent such an occurrence Polk offered Spain $\$ 100$ million in 1848 to purchase Cuba, but was unsuccessful. What Polk failed to realise was that Britain was no longer interested in extending its Empire but wanted only to develop its trading and commercial interests and protect them from competition with Europe.

In 1850 the Clayton-Bulwer Treaty was signed by the United States and England to prevent either government gaining control over a canal that might be constructed in the isthmus, or colonising or assuming "any dominion over Central America". ${ }^{5}$ From England's viewpoint it also provided some control over the expansion of the United States. But the prospect of a canal in the region encouraged private American adventurers, or filibusters as they became known, to try and gain control of Nicaragua and the passageway between the Indian and Pacific Oceans. Although not officially sanctioned their actions raised awareness in England that the United States considered the

\footnotetext{
${ }^{4}$ lbid, pp. 74-75.

5 Ibid., p. 82.
} 
Americas theirs, and the English public could see no reason why Britain should contest that fact. Public opinion on the situation was expressed in such newspapers as The Times and The Economist in June 1856. The Times believed they should not resist the expansion of the United States unless a British community was threatened or some real interest was at stake and added: "It must be for our interest to see North America under strong, civilized, uniform and prosperous government . . . . It does not become us to play the dog in the manger with our fast-growing progeny across the Atlantic." 6 The Economist went even further:

We could not hinder the ultimate absorption by the Anglo-Saxon republicans of the whole of Central America if we would.... We can have no interest in upholding the present wretched and feeble governments of Spanish America. Our interest lies all the other way. We wish ourselves for no extension of territory on that continent. . . . Desiring no territory, we desire only prosperous, industrious, civilized and wealthy customers. . . Central America peopled and exploited by Anglo-Saxons will be worth to us tenfold its present value. ${ }^{7}$

Guided by such opinions Palmerston, the British Prime Minister, recognised that Britain's commercial interests demanded a policy of maintaining peace with the United States, and that it would be impossible to contain the activities of the American filibusters without antagonising the United States. For this reason both parties agreed to abrogate the Clayton-Bulwer Treaty in 1858, and British opposition to expansion by the United States effectively ended.

France was not disinterested in the situation in Central America at this time either, and along with the United States and Britain had signed treaties in the 1850s "with the various Central American countries ... and all parties were insured territorial integrity and free rights of transit across the Isthmus." It should be realised that the idea of a canal to connect the two oceans, somewhere between Panama and the south of Mexico, had been seriously investigated and discussed for many years, having been originally suggested in the sixteenth century. With the independence of the Spanish American

\footnotetext{
${ }^{6}$ The Times, 3 June 1856. Quoted by Kenneth Boume, Britain and the Balance of Power in North America 1815 1908 (London, 1967), pp. 200-201.

${ }^{7}$ The Economist, 14 June 1856, ibid.

${ }^{8}$ William H. Goetzmann, When the Eagle Screamed, p. 82.
} 
colonies many nations were interested in ensuring freedom of access to such a communication route and also to trade with the surrounding countries, and individuals from various nations made proposals for the construction of a canal.

In the 1840 s approaches were made to foreign governments, including that of Louis-Philippe in France, to support the construction of a canal, and his government already had sent an engineer to determine the suitability of Panama. An approach from the States of Guatemala, Honduras and San Salvador was rejected by Louis-Philippe, however, so their representative asked to visit Prince Louis Napoleon, who was at that time imprisoned at Ham, and who had shown an interest in such a project after visiting the Americas sometime earlier. He was offered the opportunity to organise a company to construct a canal in Nicaragua, and while he awaited the results of a request to be released from prison to travel to America, he wrote a comprehensive brochure on the importance of a canal, with an analysis of a number of the proposed sites and details of the construction, the costs involved and the estimated revenue that could be generated by its use. As a prisoner with time to think Louis Napoleon was able to ruminate over such projects, and this one offered a feasible opportunity to obtain his release and to be assured of a worthwhile occupation while he awaited a favourable time to pursue his "destiny" in France. As approval for his release was not forthcoming, and he wished to see his dying father, he decided to escape from Ham and go to England where he waited some months for permission to visit his father in Tuscany. His father died, however, without seeing his son, and the changing political situation in France kept Louis Napoleon in England until the collapse of the Orleanist regime in 1848, and caused him to abandon the idea of going to America.

However, because of his writings on a canal in the 1840 s it was easy, in the aftermath of the Mexican intervention from 1862-1867, to accuse Napoleon of having intervened in Mexico because he had been obsessed with the strategic position of Central America and was merely awaiting an opportunity to become involved there. American historians particularly have used this reasoning. Alfred and Kathryn Hanna for example, 
suggest that "Louis Napoleon's serious reflections on an American canal to connect the Atlantic with the Pacific would appear to provide irrefutable evidence in tracing the origin of Napoleon III's Grand Design." "9 To a certain extent they were correct, for the genesis of "la grande pensée" of Napoleon III is revealed in his writings on a canal in Nicaragua, as it is in other political writings of his youth. At the conclusion of his pamphlet on the proposed canal Louis Napoleon wrote:

La prospérité de l'Amerique centrale se rattache aux intérêts de la civilisation en général, et le meilleur moyen de travailler au bien-être de l'humanité, c'est d'abattre les barrières qui séparent les hommes, les races et les nations. ... La religion chrétienne nous enseigne que nous sommes tous frères, et qu'aux yeux de Dieu, l'esclave est égal au maittre, - de même que l'Asiatique, l'Africain et l'Indien sont égaux à l'Européen. D'un autre côté, les grands hommes de la terre ont, par leurs guertes, mêlé ensemble les differents races, et laissé derrière eux quelques-uns de ces impérissables monuments, tels que l'aplanissement des montagnes, le percement des forêts, la canalisation des rivières, monuments qui, en facilitant les communications, tendent à rapprocher et à réunir les individus et les peuples. La guerre et le commerce ont civilisé le monde. La guerre a fait son temps; le commerce seul poursuit aujourd'hui ses conquêtes. Ouvrons-lui une nouvelle route. Rapprochons de l'Europe les peuplades de l'Océanie et de l'Australie, et faisons-les participer aux bienfaits du christianisme et de la civilisation. ${ }^{10}$

What these writings do show is not an obsession with Central America for narrowly strategic reasons, but rather an awareness of the advantages for world harmony of another avenue to facilitate communication between nations and the mixing of peoples of varied origins. The most important point in this passage is his comment that the only way to "civilise" the world was no longer through war but through commerce. This was the "grand idea" of Louis Napoleon, not the maintenance of conservative monarchical institutions in the Americas to oppose the growing number of republican governments, as suggested by many contemporaries and historians like $\mathrm{A}$. and $\mathrm{K}$. Hanna. Instead what is evident here is the core of the policy of Louis Napoleon as Emperor.

It is in this respect that the historiography of the Mexican intervention has been seriously lacking. There has been no attempt to place this campaign within the context of

\footnotetext{
${ }^{9}$ A.J. Hanna and K.A. Hanna, Napoleon III and Mexico: American Triumph Over Monarchy (Chapel Hill, 1971), pp. 66-67.

${ }^{10}$ Napoleon III, "Le Canal de Nicaragua", CEuvres de Napoléon III (Paris, 1869), Vol. 2, pp. 542-543.
} 
Napoleon's foreign policy, perhaps because so many people believed he did not in fact have a policy, but also because the available sources have not been taken seriously enough. This can be said especially of the writings of Louis Napoleon as well as of his correspondence, and of his repeated attempts to convene a European Congress. It will be remarked that the historiography of this expedition is dated, so for this reason also a fresh analysis not unwarranted. Given the fact that the Second Empire was the longest lasting period of government since the Revolution, it is significant that the entire period, not just the Mexican campaign, has been seriously neglected by historians.

The earliest works on Mexico were largely memoirs or observations of contemporaries, until the appearance in 1906 of Paul Gaulot's work based on the correspondence of General Bazaine with Napoleon, Marshal Randon the Minister of War, and others, collected by Ernest Louet, the chief paymaster of the French expeditionary forces in Mexico. ${ }^{11}$ This is one of the few historical works that have been sympathetic to Napoleon III, and it emphasised to what extent he was misinformed and badly served by his Minister in Mexico and his commanders. It was also the first time a large collection of personal correspondence was used in a study of the campaign, previous accounts being based solely on official and published documents and correspondence from members of the expeditionary forces. Little more appeared until 1928 when Egon Corti gained access to the archives of Maximilian which were held in Vienna. The result of his study was the large work, Maximilian and Charlotte of Mexico, which addresses the negotiations between Maximilian and Napoleon, and Maximilian and the Mexican emigrants in Europe, and follows the progress of the Mexican Empire until its collapse in 1867.12 While drawing on only the correspondence of Napoleon with Maximilian in the Viennese archives, published sources and secondary works, Corti concluded that Napoleon was determined to impose a monarchy on Mexico, and that he only ever intended a token gesture be made to universal suffrage to decide Mexico's

\footnotetext{
11 Paul Gaulot, L'Expédition du Mexique 1861-1867 d'après les documents et souvenirs de Ernest Louet Payeur en chef du Corps Expéditionnaire (Paris, 1906).

${ }^{12}$ Egon Cæsar Count Corti, Maximilian and Charlotte of Mexico. Translated from the German by Catherine Alison Phillips (Archon Books U.S.,1968 (C) 1928).
} 
destiny. His evidence to support this claim is far from conclusive, however, and while others have agreed with his assertion none has given anything other than anecdotal evidence or conjecture to support his arguments.

In 1935 Daniel Dawson added a study of the British Foreign Office papers from the Embassies of Paris, Madrid, Vienna and Washington, and of the legation in Mexico City, to the sources used by Corti, and he concluded that Napoleon's reasons for being involved in Mexico were to pose a threat to the expansion of the United States by imposing a Latin Catholic bloc in Central America. ${ }^{13}$ Napoleon's economic adviser, Michel Chevalier, wrote a large work on Mexico in which he justified intervention there on the basis that France needed to ensure its greatness by preventing the spread of Protestantism into the Americas by preserving the Latin Catholic culture there. ${ }^{14}$ While there is no evidence that Chevalier's views were shared by Napoleon - in fact there is much to deny it - Dawson, and later A. and K. Hanna, said that this was his prime motivation for intervention simply because of his close relationship with Chevalier. Christian Schefer, who mainly researched France's colonial exploits during earlier and later regimes, was the first to make use of the archives of the French Ministry of Foreign Affairs and he examined the origins of the expedition. He saw that the primary aim of Napoleon's foreign policy was to cement alliances with Britain and at least one European neighbour, and the Mexican venture, in conjunction with England and Spain, provided an ideal opportunity to do this. Such an expedition might also help ensure the Americas remained open to the commerce of Europe and the rest of the world, a more humanitarian motive than others had ascribed to Napoleon. Schefer, however, concluded that the Mexican venture failed to become "la plus grande pensée de la règne" because of the ineptitude of Napoleon. ${ }^{15}$ But again his archival support was limited because he did not, or was unable to, consult many of the private papers in the Archives Nationales, or the records of the Minister of War, and did not consult the British archives at all.

\footnotetext{
${ }^{13}$ Daniel Dawson, The Mexican Adventure (London, 1935).

${ }^{14}$ Michel Chevalier, Mexico Ancient and Modern 2 Vols. Translated under the author's superintendence by Thomas Alpass (London, 1864).

${ }^{15}$ Christian Schefer, La Grande Pensée de Napoléon III: Les Origines de l'Expédition du Mexique (1858-1862) (Paris, 1939).
} 
Carl Bock in the 1960s did an exhaustive study in the French and British Foreign Ministry archives for his analysis of the negotiation and breakdown of the Convention between England, France and Spain in 1861.16 Although he provided a valuable understanding of the forces acting on all sides in this period he commented that only a few letters written by Napoleon were on file in the Archives du Ministère des Affaires Étrangères. This meant that he did not read the many letters and instructions Napoleon did write, a large proportion of which are to be found in the Archives Nationales, and his conclusions were influenced by the opinions of others who had written before him. Like Corti he was convinced that Napoleon searched for an excuse to impose a monarchy in Mexico, and that he and Eugénie were obsessed with the idea, but he has little to support this argument other than the comments of contemporaries such as Lord Cowley, the British Minister in Paris.

As mentioned above, A. and K. Hanna reached similar conclusions to Dawson even though they consulted a wider range of documents. Their consultation in both the Archives Nationales in Paris and the Public Record Office in London was very sparing, however, and their main emphasis was on the Mexican and United States sources in an effort to show that Napoleon was forced to conclude the intervention because of pressure from the United States. Ralph Roeder provided some interesting information on the intervention in his work on Juarez, using the Bazaine archives kept in Texas, Juarez's private archives, and an exhaustive list of secondary sources. He was able to provide views from numerous Mexican sources to support or add to the European sources, particularly in relation to the activities of the Comte de Gabriac and Dubois de Saligny, the French Ministers in Mexico in the 1850s and 1860s. His portrayal of the Mexican political and social situation in this period provided valuable background for the study of the intervention. ${ }^{17}$ Later works, in the 1970 s, each focused on different aspects of this

\footnotetext{
${ }^{16}$ Carl H. Bock, Prelude to Tragedy: The Negotiation and Breakdown of the Tripartite Convention of London, October 311861 (Philadelphia, 1966).

${ }^{17}$ Ralph Roeder, Juarez and his Mexico (New York, 1947). Roeder's work was termed a biographical history, and was praised as one of the best books written in English on the history of Mexico. He has an enormous bibliography but has provided no citations whatsoever, which makes it difficult to confirm the validity of his sources. However, his opinions on Saligny, for example, are generally supported by other sources I have quoted. His archival sources included the private archives of Benito Juarez and the ten volume Bazaine archives
} 
interlude: on Maximilian and Charlotte; on the British involvement in the intervention; or on analysis of possible economic motives for Napoleon's intervention. ${ }^{18}$ Any other publications have been a revision of previous work without the authors consulting the archives themselves, except for the most recent work of Jean-François Lecaillon who has presented an analysis of the conduct of the campaign from the point of view of the soldiers who served in Mexico. To do this he has used journals, memoirs and collections of private letters of the soldiers to add to the studies already done on this campaign. ${ }^{19}$

In summary, then, it appears that there are very few analyses of the Mexican intervention that have been based on archival research, and each of those cited above has been selective because of unavailability of documents, at least in the 1930s, or because of a bias towards either the American, the British or the French point of view. Most significantly, no original archival research has been done since the 1970s. I have also been selective in that I have not consulted the American, Austrian, Spanish or Mexican archives and have relied on published sources for those viewpoints. I have, however, consulted as wide a range of sources as possible in the French and British archives. Apart from the British and French Foreign Ministry archives and those of the French Minister of War, I found valuable documents in the files of the Ministry of Marine and Colonies in the Archives Nationales, as well as among private papers, particularly those of the Bonaparte family. There were also two cartons of papers relating to the Mexican campaign amongst those found in the Tuileries in September 1870, and many other valuable documents in the same series. From these additional sources I was able to find many more original letters and instructions written by Napoleon which confirmed his intentions in Mexico.

Napoleon's intervention in Mexico attracted much criticism both at home and

kept in Texas which contain valuable material relating to the intervention. His secondary sources include Mexican, French and English published works.

${ }^{18}$ See Joan Haslip, Imperial Adventurer: Emperor Maximilian of Mexico and his Empress (London, 1974 (C) 1971); Shirley Black, Napoleon III and the French Intervention in Mexico: A Quest for Silver, Ph. D.

Dissertation, University of Oklahoma, 1974; Gary M. Poulton, Great Britain and the Intervention in Mexico $1861-1865$.

19 Jean-François Lecaillon, Napoléon IIt et le Mexique: Les illusions d'un grand dessein (Paris, 1994). 
abroad, much of which will be seen to have been unwarranted. But an understanding of this criticism can perhaps be gained by considering at what stage in the development of the Second Empire that this campaign took place. In November 1860 Napoleon had begun to introduce some liberal reforms which allowed for discussion of the annual address, the right to propose amendments to bills, and the publication of parliamentary debates. The following year parliament was given "the right to discuss the budget clause by clause", ${ }^{20}$ which gave it unprecedented control over government expenditure. This meant that for the first time opposition to the policy of the Emperor could have an impact on the carrying out of that policy, and Mexico was the first foreign involvement, apart from the Italian question, to be subjected to extensive debate and questioning in the Corps législatif. As Peter McPhee remarks, once liberalisation began Napoleon found that "political opposition simply moved to occupy the widening opportunities for dissent, a phenomenon common to authoritarian régimes ever since."21 Mexico was also to be the first lengthy military campaign of the Empire, and for this reason it attracted opposition from not only political opponents but also from the public, who were used to the short decisive campaigns of recent years. While there was concern expressed that France could not withdraw from Mexico without preserving its honour, the majority of people did not understand the reasons France was involved in Mexico, and its distance from France meant it was not as important to them as resolving the problems that were beginning to develop on their doorstep. ${ }^{22}$ While the influence of the pressure from his parliament and public opinion is difficult to determine, it is highly probable that the verbal and written opposition to this campaign has had an impact on how it has been regarded by historians.

The Mexican problems also arose shortly after Napoleon had concluded the Commercial Treaty with England, one of the major achievements of his reign for it not only boosted France's exports but was a profound indication of his intention to preserve peace with England. The idea of a campaign in conjunction with England and Spain was,

\footnotetext{
20 James E. McMillan, Napoleon III (London, 1991), p.65.

${ }^{21}$ Peter McPhee, A Social History of France, 1780-1880 (London, 1992), p. 212.

${ }^{22}$ Lynn M. Case (ed.), French Opinion in the United States and Mexico 1860-1867 (Archon Books U.S., 1969

(C) 1936), pp. $331 \mathrm{ff}$.
} 
to him, an ideal opportunity to further develop his relations with his neighbours and pursue his goal of a united Europe. That this campaign was to be in the Americas was an added bonus because achieving a world free of barriers to trade would be the final step towards a universal agreement to maintain peace. While many have concluded that Napoleon had a simplistic world view which entailed maintaining a Latin Catholic culture in the Americas, particularly as a barrier to the spread of republicanism and Protestantism, the sources suggest his policy was much more far-sighted. I have analysed this policy from its very early development in the writings of his youth, from his addresses and notes regarding foreign policy during his reign, and from his numerous proposals for the convening of a European Congress. This research has shown he had a consistent policy, in the context of which Mexico can be placed. From the evidence, it is possible to dismiss the claims of many analysts and contemporaries that his main aim was a determination to impose a Latin, Catholic, monarchical bloc to the expansion of the United States.

A further difference in my conclusions drawn from the sources is that while most have recognised others, such as the Minister in Mexico, Dubois de Saligny, and the Commanders, Admiral Jurien de la Gravière and General de Lorencez, misled Napoleon, they have treated this fact lightly and concluded that when they appeared to be acting in contradiction of their written instructions, they were in fact carrying out Napoleon's secret orders. The only support for such a claim appears to be a comment made by the Austrian Ambassador, Prince Richard de Mettemich that Jurien had been given secret instructions to ensure a monarchy was chosen as the form of government in Mexico. Napoleon's written avowals that he was happy for Mexico to choose the government it wanted, whether monarchical or republican, were said to be masking his real intentions, yet it can be shown that when reports from his commanders revealed they had misinterpreted their instructions he took great pains to clarify his intentions. The most significant example of this is in his instructions to General Forey when he was sent to take over command from Lorencez, but this letter has been wrongly used by historians to support their belief in Napoleon's anti-American policy. Perhaps it is assumed that, 
because his agents acted in opposition to their written instructions, there must have been secret ones. The correspondence of Jurien and Forey, however, shows that they consciously acted on their own initiative and either justified not following their instructions or took responsibility for their decisions. The true importance of their despatches has until now been overlooked or ignored.

It is possible that Napoleon's Mexican policy was misunderstood simply because his overall foreign policy has been, the most common interpretations being that Napoleon was inconsistent, impuisive, determined to extend France's borders and regain mastery of Europe, and that he did not know with whom to form a strong alliance. At various times he courted each of the major Powers but with limited success, and this has been interpreted as a lack of any real direction in his policy. However, in recent years William Echard has shown quite convincingly that there was indeed a consistent aim in Napoleon's foreign policy. By focusing on his repeated attempts to convene a European Congress, Echard shows that he was faithful to the ideas, revealed in the writings of his youth, that envisaged a united Europe free from internal struggles. His attempts at cementing alliances with different Powers are seen to be purposeful steps along the way to achieving his goal. ${ }^{23}$ My own ideas on Napoleon's foreign policy have developed along similar lines to those of Echard as a result of studying Des Idées napoléoniennes, Rêveries politiques, and other writings, and my research shows that Napoleon envisaged his ideas relating to Europe would one day be extended to encompass the world. The Mexican intervention can thus be seen as an illustration of how his world policy might have been achieved. This idea goes against the general survey of Napoleon's foreign policy, as the most recent work in English on Napoleon III would suggest. McMillan recognises the value of Echard's work, but concludes that

Napoleon III could be represented both as the champion of liberal and national causes and as a practitioner of a new style of congress diplomacy, which aimed at the resolution of conflicts without war. It makes more sense, however, to see them as occasions which the Emperor seized in order to give France the diplomatic initiative and to help prepare the way for the general reorganisation of the map of Europe that was his consuming

${ }^{23}$ William E. Echard, Napoleon III and the Concert of Europe (Baton Rouge, 1983). 
ambition. ${ }^{24}$

MacMillan's conclusions, however, are drawn from the work of others, and this shows, I believe, a need for much more intensive research into the foreign policy of Napoleon III.

Des Idées napoléoniennes were a reflection of Louis Napoleon's views of the intentions of his uncle, Napoelon I. His preface to this work described what he believed the Napoleonic Idea to be:

Planant au-dessus des coteries politiques, exempte de tout préjugé national, elle ne voit en France que des frères faciles à réconcilier, et dans les différentes nations de l'Europe que les membres d'une seule et grande famille. ${ }^{25}$

Later he added:

Répétons-le . . . l'idée napoléonienne n'est point une idée de guerre, mais une idée sociale, industrielle, commerciale, humanitaire. ${ }^{26}$

How correct he was in his assessment of the intentions of his uncle must be left to historians of the First Empire to decide, but Des Idées napoléoniennes and later writings and addresses reveal a view of the world that his contemporaries could not or would not accept. Louis Napoleon grew up in the Romantic era, and his writings of the 1830s and 1840 s reflect the idealism of the time. He did not lose that idealism and his later writings reveal that the beliefs of his youth were firmly embedded. Émile Ollivier recognised this and remarked that most people made the mistake of not understanding this fact. $\mathrm{He}$ wrote:

Le tort de ceux qui ont regretté ou condamné, suivant qu'ils étaient favorables ou contraires, la politique extérieure de Napoléon III, de ceux surtout qui l'ont déclarée énigmatique, est d'avoir en quelque sorte retiré ce souverain des idées générales au milieu desquelles son esprit s'est formée et dont il a été plus tard un reflet, et, au lieu de le raltacher au mouvement de son temps, de le considérer comme une individualité solitaire ne relevant que d'elle-même. ${ }^{27}$

\footnotetext{
24 James E McMillan, Napoleon III, p. 81.

25 Napoleon III, "L'Idée napoléonienne", Euvres de Napoléon III, Vol. I, pp .8-9.

26 Napoleon III, "Des Idées napoléoniennes", ibid., p. 172.

27Émile Ollivier, "Napoléon III: Son dessin international", Revue des Deux Mondes (R.D.M.), Vol. 146, 1

March 1898, p. 49.
} 
What has happened is that instead of seeing in his ideas the basis of his foreign policy, both contemporaries and historians have dismissed him as dangerous or as a Utopian dreamer.

When he spoke of the problems engendered by the Congress of Vienna his European counterparts feared he wanted to regain annexed territories, and extend France's borders even beyond those territories. Therefore they were constantly anticipating he would go to war to achieve those aims, and remained suspicious of all his proposals to discuss the problems of Europe in case he intended to force other nations to cede part of their lands. This misunderstanding of his policy was to influence England in particular in its attitude to France, and to be a bartier to an effective relationship between the two nations. According to the young Louis Napoleon, the Treaties of 1815 had not only left France weaker, but had based European equilibrium on the rivalries of the great Powers rather than on the interests of all nations. He believed that if his uncle's idea of a European association founded on complete nationalities and on satisfied general interests had been achieved, the problems caused by the Vienna "settlement" would never have happened, because communal interests would have taken priority over individual interests. He described the situation that would have existed with such an association:

Chaque pays, circonscrit dans ses limites naturelles, uni à son voisin par des rapports d'intérêt et d'amitié, aurait joui à l'intérieur des bienfaits de l'indépendance, de la paix et de la liberté. Les souverains, exempts de crainte et de soupçon, ne se seraient appliqués qu'à améliorer le sort de leurs peuples, et à faire pénétrer chez eux tous les avantages de la civilisation! ${ }^{28}$

It was this notion of sharing ideas and civilisation that was fundamental to the foreign policy of Napoleon III, and Echard concluded "that only within the context of a certain idea of Europe does the foreign policy of Louis Napoleon begin to make sense."29 He believed the reason others have been unable to find an explanation for Napoleon's apparent difficulty in deciding with whom he wanted an alliance was because they have tried to interpret his policy "in terms of the ends [sic] sought" when it was

${ }^{28}$ Napoleon III, "Des Idées napoléoniennes", p. 162.

${ }^{29}$ William E. Echard, Napoleon III, pp. 2-3. 
in fact developed in terms of the means [sic] by which those ends were to be achieved. The consistent purpose of the alliances and ententes entered into or sought by Napoleon between 1849 and 1863, then, would have been to make the concert of Europe function as he wished it to function, that is, to bring the powers together in general congresses that would reorganize Europe, solve its most urgent problems and thereafter regulate the new arrangements. ${ }^{30}$

There were many, though, who believed Napoleon did not in fact have a policy. This assumption could have been made because he had a philosophy of government based on a comment by Napoleon I: "Je n'avais pas la folie ... de vouloir tordre les événements à mon système; mais, au contraire, je pliais mon système sur la contexture des événements." 31 And this was what Napoleon III did, leading many to feel insecure or threatened by his seemingly unpredictable diplomacy, and others to see him as a political opportunist. What was consistent was his determination to cement a firm alliance with England and with at least one of his continental neighbours, but they always remained suspicious of him. The collusion that occurred between England and Austria on at least two of the occasions Napoleon suggested a European congress ensured the congresses never took place.

The main cause of the suspicion on the part of England was that its opinion on how best to maintain peace in Europe was almost diametrically opposed to that of Napoleon. Palmerston, as Prime Minister and Foreign Minister in the 1840s and 1850s, was convinced that the territorial settlements of 1815 were still the best guarantee of peace because they helped maintain the balance of power. By this he meant that no one State could assume a position of hegemony, in particular France or Russia, so any suggestion of an adjustment in territorial frontiers he saw as a threat to that balance of power. Prior to, and in the early years of the Second Empire Palmerston believed the conservative elements in France would cooperate in the maintenance of that balance so "he made friendship with France a prominent feature of his policy." 32 This changed to concern,

30Ibid., pp.182-183.

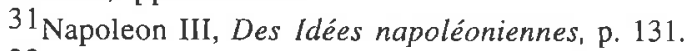

32 F.J.C. Hearnshaw, "The European Revolution and After, 1848-1854", The Cambridge History of British Foreign Policy 1783-1919, edited by Sir A.W. Ward and G.P. Gooch (Cambridge, 1923), pp. 335-336. 
however, after the Empire was proclaimed in 1852, and in the late 1850s Palmerston became almost paranoid about a possible invasion of England by France when it appeared that France's navy, employing the new iron clad ships, might rival Britain's own. Richard Cobden commented that Palmerston had come to office with the promise he would always keep on friendly terms with France and yet he wasted the country's resources building fortifications to withstand an invasion from that country. ${ }^{33}$ In 1859 and 1860 there had also been public demonstrations held around the country to establish rifle corps in the face of Palmerston's anxiety which was based on absolutely no factual evidence. 34

A turning point seems also to have been after the negotiations by Napoleon for the cession by Sardinia of Nice and Savoy to France, which followed his role in organising the ceding of Tuscany to Sardinia in January 1860. England was not affected at all by these changes, and the people of each of the provinces voted in favour of them, but Palmerston feared this move by Napoleon presaged further demands for expansion of France's frontiers and a threat to the balance of power. The only possible impact on British interests would be if Napoleon eventually insisted on the cession of Genoa and Sardinia in exchange for his consent to the annexation of Naples and Sicily to Italy, which might threaten Britain's Mediterranean possessions of Malta, Corfu and Gibralter. ${ }^{35}$ These concerns were totally unfounded but, combined with a perceived challenge to England's naval supremacy, they had considerable impact on relations between the two governments for several years. Even the conclusion of a Commercial Treaty between France and England in 1860, instigated by Napoleon and benefiting both nations, could not allay Palmerston's fears of an invasion by France. Yet to Napoleon and English politicians such as Richard Cobden, such a commercial relationship was a guarantee of peace.

\footnotetext{
33 Richard Cobden to the House of Commons, 1 August 1862. John Bright and James E. Thorold (eds.)), Speeches on Questions of Public Policy by Richard Cobden. M.P. (London, 1878), pp. 440-441.

34 Richard Cobden, Speech to his constituents at Rochdale, 26 June 1861. Ibid., p. 433.

${ }^{35}$ Rachel R. Reid, "The Franco-Italian War, Syria and Poland 1859-1863", ibid., pp. 445-446. ?
} 
There were some fundamental differences between the two countries which contributed to their lack of understanding of each other, not the least of these being their systems of government. Parliamentary democracy was a well established institution in England, whereas in France it was barely in its infancy at the time negotiations took place to prepare for the tri-partite intervention in Mexico. The significance of this difference has not really been highlighted enough in the studies of the Mexican campaign, but the development of foreign policy in each country varied considerably because of it. In France foreign policy was developed almost solely by Napoelon, with even the opportunity for the Senate and Corps législatif to propose amendments being introduced only in late 1860. In England, on the other hand, the Blue Books, the publication containing diplomatic correspondence, had been readily available since early in the century and provided the opportunity for widespread criticism of government foreign policy. Although correspondence was not available until an incident was concluded, and could of course be heavily edited, the Blue Books still provided a wealth of information that could be analysed and criticised. No other country had its policy so exposed to public scrutiny, and this exposure increased with the availability of transcripts of parliamentary debates and the use of newspapers and journals for politicians to espouse or defend their views. ${ }^{36}$ Concern over parliamentary and public opinion on intervention in Mexico created noteworthy problems during negotiations between France and England, the English Ministers agreeing verbally with many of Napoleon's ideas but not committing themselves to the same views in writing or before the Parliament. The result was that when Napoleon's ideas regarding Mexico became public Palmerston and Russell, the Foreign Minister, were able to deny prior knowledge of them and distance themselves from the acrimony that was directed at Napoleon.

With the progress of events in Europe in the last decade it is timely to reconsider the man who envisaged a path to peace in Europe over a century ago, and the Mexican. campaign provides the opportunity to see how Napoleon's vision could have extended

\footnotetext{
${ }^{36}$ Kenneth Bournc, The Foreign Policy of Victorian England 1830-1902 (London, 1970).
} 
beyond Europe to encompass the world. This thesis examines briefly the history of Mexico that led to the decision of the governments of France, England and Spain to intervene to seek redress for wrongs and to see a more stable regime continued thereafter. It then examines the negotiations for a convention between the three governments, which took place against the political backgrounds described above. A significant aspect of the campaign was the role played by the representatives in Mexico of each of the governments, especially the French Minister and commanders. An analysis of their correspondence will show that they misinterpreted the intentions of the Emperor and should share the responsibility for the course that the intervention finally took. Understanding their roles is essential in determining to what extent Napoleon should be blamed for the disaster of the Mexican intervention, and for this reason it is a major focus of this thesis. In undertaking this analysis I have consulted all letters and reports, both open and private, as well as the addresses and writings of Napoleon III, with an open mind. I have discounted the secret, verbal instructions referred to by various contemporaries and analysts because they are impossible to verify, and the source of such information seldom identified. In most instances there is a wealth of written information which refutes the anecdotal evidence, and Napoleon's correspondence consistently reveals his motives were faithful to l'idée napoléonienne. Echard shows similarly how Napoleon's idea of a European Congress is faithful to that idea and his work supports the view that Napoleon's statements can be taken seriously. 


\section{Uthapter 1}

\section{Calls for Jatervention}

Mexico gained its independence from Spain in 1821 in a move prompted by the clergy's fear of losing its privileges, but this independence heralded a lengthy and bloody quest for stability. For forty years a struggle continued between the Conservatives, supporting the Church, and the Liberals who wished to reduce its power and influence in the country. Those years saw as many governments and even more Presidents, each taking the place of the previous one by use of a Mexican system, in the Spanish tradition, called a pronunciamento. This was the act of changing the government and assuming authority simply by making a proclamation, which meant the country was doomed to continual anarchy and instability unless this system was changed. The most dominant element in the search for power was the Church, which had managed, with the help of Fernand Cortez and numerous bequests from wealthy Mexicans, to accumulate almost a third of the wealth of the country. It was in reaction to this that the Liberals struggled to wrest control from the Conservatives and reduce the political influence of the Church. Although the Liberals gained control for a time in 1823, it was not until 1833 that any serious attempt was made to address this issue, and that was under the direction of Antonio Lopez de Santa Anna, who served various periods as President over the years. He tried to repress the political influence of the clergy; secularised public education; determined that the clergy should be allowed to renounce their vows; and began the secularisation of Church property. But when the government moved to reduce the size of the army, which was firmly under the influence of the Church, both the army and the Church united against the government, and eventually Santa Anna decided to side with the Church and the Conservatives.

In the following twenty years three new constitutions were drawn up, and while each addressed the issue of providing a franchise, the limitations of that franchise differed in each of them, as did the attitudes to the Church. In 1836, under the 
Conservatives, the rights and duties of Mexican citizens were defined, and the franchise given to adult males with an income of 100 pesos, but in 1843 these same Conservatives raised the income threshold for voters to 200 pesos which automatically excluded the Indians who worked mainly as farm hands or labourers. This latest constitution also declared that the Roman Catholic religion was the only one allowed in Mexico, which dealt another blow to the Liberals. ${ }^{1}$ The struggle for freedom from this oppression continued, resulting in a constant state of anarchy, which led some Mexicans to entertain the idea of approaching European governments to provide Mexico with a sovereign, in the hope he might bring some stability. In 1855 Santa Anna commissioned José Miguel Gutierriz Estrada, a Mexican exiled in Europe since 1840, to find a European sovereign, but his approaches were rejected everywhere and Santa Anna himself was soon ousted from power by the Liberals.

The Liberals, led firstly by Diego Alvarez and then Ignacio Comonfort, immediately began introducing reforms which seriously attacked the position of the Conservatives. Some Church property was confiscated, and on 5 June 1856 an order was issued suppressing the Jesuits and allowing the forswearing of vows by members of religious orders and the clergy. This was followed by the abolition of the right of civil and ecclesiastical corporations to hold real property, except that directly used for worship. The idea was "to force all large property holders to disgorge and sell their enormous holdings, so as to get the land into the hands of the middle and poorer classes and give them the incentive which comes from private ownership". ${ }^{2}$ As this mainly affected the Church, however, the issue was really between the Church and the State. In pursuance of these laws a Constituent Congress drafted a new constitution that was presented in February 1857 and accepted by Congress in September that year. It was a radical document and not to be accepted by the Conservatives who proposed an alternative constitution in a crisis which erupted in January 1858. The Liberal Constitution gave the franchise to males aged eighteen if they were married, and twenty

\footnotetext{
${ }^{1}$ Wilfred Hardy Callcott, Church and State in Mexico, $1822-1857$ (New York, 1965), pp. 88ff. and 132ff. 2Ibid., p. 249.
} 
one if not; provided for a constitutional federal government; provided freedom and protection of slaves; freedom of religion; freedom of the press; encouraged immigration from all countries, and enterprise in industry, especially mining and international imports; the military was to be under civil powers and military and ecclesiastical privileges were abolished; and Church property worth $\$ 200,000,000$, the income from which was worth $\$ 20,000,000$, was to be nationalised. ${ }^{3}$

After the constitution was presented, however, President Comonfort found he was unable to support it because of its impact on the Church and he made a pact with the Conservatives, accepting a counter proposal by them and breaking with the Liberals. The Conservative plan proposed: the inviolability of Church property and revenues, and re-establishment of former exactions: re-establishment of privileges for the army and clergy; the Roman Catholic religion as sole and exclusive religion in Mexico; censorship of the press; immigrants to come only from Catholic countries; overthrow of the Constitution of 1857 and use of a central dictatorship subservient to the Church only; a monarchy to be established if possible, but if not, a European protectorate. ${ }^{4}$ It was in effect the complete antithesis of the Liberal Constitution and became effective because of Comonfort's defection to the Conservatives. Comonfort, however, was then ousted by General Felix Zuloaga, who declared himself President of a now Conservative government, in January 1858. But this was to be the beginning of a civil war which raged for three years, and it was in this time that calls for intervention by European governments became stronger and were to lead to even greater upheaval within the country. In reaction to Comonfort's coup d'état, Benito Juarez, a senior minister in his cabinet, declared an alternative government in February 1858, which eventually took up residence in Vera Cruz. This government was considered the legal and constitutional government, because it was supported by the majority of State governors and by public opinion in sixteen out of twenty two States. ${ }^{5}$ While turmoil reigned in Mexico, the foreign governments dealing with the country were faced with the dilemma of deciding

\footnotetext{
${ }^{3}$ Ibid., p. 315.

${ }^{4}$ Ibid.

${ }^{5}$ Ralph Roeder, Juarez and his Mexico, p. 193.
} 
which of the two Mexican governments they should recognise, and whether they should heed the calls from both Mexicans and their own representatives to become involved in the crisis.

Although there were several informal approaches to the European governments by Mexican emigrants over the years, the first official one was made by Zuloaga in 1858, in accordance with the alternative proposal to the Constitution of 1857. It met with varied, but cautious reactions, however, from France and England. He requested the French and English representatives in Mexico, de Gabriac and Otway, to ask assistance from their governments for the re-establishment of order and security in the country, as well as the complete reorganisation of its administration. The French Minister of Foreign Affairs, Count Walewski, commented to his Minister in London that it was evident that, left to itself, no Mexican Government would be able to prevent a dissolution "which was incontestably imminent." He felt that Zuloaga's request was made in the fear that one day Mexico would be absorbed by the United States, and the situation was therefore worthy of close examination by England and France, in view of the prospect of interoceanic communication being controlled by the United States. ${ }^{6}$

The view of the British Foreign Minister, Lord Malmesbury was that he did not think that Mexico had reached a state where it would be prepared to submit itself to somebody else's protection and, besides which, England was not prepared to undertake such a mission. He also thought it highly likely that Mexico would one day be absorbed by the United States and he believed that this solution would be most advantageous for Europe because it would open up better trading opportunities with the Southern States of America and probably lead to a division, and later the dissolution of the United States. He thought this was probably why the United States had not already tried to annexe Mexico. ${ }^{7}$

\footnotetext{
${ }^{6}$ Walewski to Pelissier, French Minister in London, 18 September 1858. Archives du Ministère des Affaires Étrangères (AMAE): Correspondance Politique (CP) Angleterre, Vol. 711.

${ }^{7}$ In a dispatch from Pelissier to Walewski, 27 September 1858. AMAE: CP Angleterre, Vol. 711.
} 
In the meantime reports reached Paris in October 1858 that the Spanish were preparing the departure from Cadiz of an expedition to Mexico to press their claims against the government, thus pre-empting any joint venture, as they were to do again in 1861. General Almonte, the Mexican Minister in Paris for Zuloaga, asked England and France to mediate between Spain and Mexico but Spain rejected such an offer. In early November Marshal O'Donnell, the Spanish Prime Minister, told M. Fournier, now the French Minister, and Sir G. Buchanan, the English Minister in Madrid, that if Mexico did not accept its forthcoming ultimatum, Spain was prepared to go to war - with the United States as well if necessary. Buchanan was convinced Spain wanted to drag France and England into a war with her against Mexico and the United States, purely to prove her strength. ${ }^{8}$ Buchanan advised Lord Russell, now Foreign Minister, of this, adding that Marshal O'Donnell was determined to be firm and Spain had plenty of ships in the vicinity of its possessions in the area. ${ }^{9}$

These moves for some kind of intervention in Mexico did not come to fruition for various reasons which will be discussed shortly, but it is valuable to consider the aims and actions that were proposed in this earlier situation. Buchanan wrote to Russell that both Calderon Collantes, the Minister of State for Foreign Affairs, and O'Donnell had more than once suggested "that it will be the interest and duty of England and France to adopt measures in concert with Spain for encouraging the re-establishment of some legitimate authority in Mexico and for restraining the aggressive policy of the United States towards their southern neighbours."10 At this time they suggested that "moral influence" alone would probably be sufficient to achieve this end if the European powers adopted a firm policy. Although these motives expressed by Spain will be seen to be integral to Napoleon's policy in 1861, at this time Buchanan believed Spain's motives were really more base than these. He thought Spain was looking to renew its prestige and interests in the West Indies and South America, and that the Spanish government

\footnotetext{
${ }^{8}$ Foumier to Walewski, 7 November 1858. AMAE: CP Espagne, Vol 852.

${ }^{9}$ Buchanan to Russell, 7 November 1858. Public Record Office (PRO): Foreign Office (FO) 72/940.

${ }^{10}$ Buchanan to Russell, 8 November 1858. PRO: FO 72/940.
} 
was convinced that if problems arose with the United States, England and France would eventually become involved. He informed O'Donnell and Collantes, however, that if Spain did engage in a war to further this end, it was most unlikely that England and France would wish to become involved. It seemed that the United States were occupied with difficulties in Paraguay at the time and Spain was hoping to take advantage of this opportunity. The United States had also been making suggestions about buying Cuba from Spain, and according to Fournier, it was Spain's fear of losing Cuba if it went to war with the United States that made it decide to maintain peace with Mexico and gain satisfaction through other means. Fournier also thought the Spanish Government was making lots of noise about foreign affairs in an effort to gain some glory for Spain and take the focus off internal affairs. ${ }^{11}$

Spain's apparent determination to use force against Mexico seemed to dissipate over the following weeks, however, but Collantes began discussions with France on the advantages of seeing a stable government re-established in Mexico. The Spanish Minister in the United States had reported that the United States had little confidence that they could either establish a government in Mexico or find a party they could support, and he seemed to be suggesting that it was therefore up to the European nations to do something in the interests of Christianity and European culture. Collantes wrote to Alesandro Mon, his Minister in Paris, that he thought France, England and Spain should adopt a firm attitude regarding the integrity of the territory of the Mexican Republic and the conservation of her nationality, and guarantee to Mexico that none of them wished to make it a protectorate. By doing this they could encourage the formation of a stable government without actually interfering in the country's politics. ${ }^{12} \mathrm{He}$ later said that Spain only wished to re-establish good relations with her former colony and to see Mexico happy and prosperous because of the factors, such as religion and language, that

\footnotetext{
11 Fournier to Walewski, (n.d.) AMAE: CP Espagne, Vol. 852. The 1850s had seen much instability in Spain with a revolution in 1854 and constant battles between the various factions in succeeding years. O'Donnell had taken control of the ministry in June 1858 and maintained his position until March 1863. Although it was remarked that his was "the most stable ministry constitutional Spain had seen", O'Donnell was constantly faced with revolt by political notabilities against his administration, and was finally forced to resign on 27 February 1863. Raymond Carr, Spain 1808-1939 (Oxford, 1975, (C) 1966), p. 260.

${ }^{12}$ Collantes to Mon, 9 December 1858. Archives Diplomatiques (A.D.), pp.207-208.
} 
bound the two nations together. All that Spain wanted for Mexico was to see it grow by being at peace with other countries and achieving internal order. ${ }^{13}$ In July 1859 Collantes again suggested to Britain that action should be taken by the three nations to help resolve the internal problems of Mexico, and help prevent it being annexed one day by the United States. Russell did not think that interference by the European Powers was likely to settle Mexican affairs permanently so was not inclined to be involved, and nor was he moved by Collantes's concerns about the United States. ${ }^{14}$ British residents had also appealed to their government to protect British commerce and prevent Mexico being exploited by the United States, who "would soon acquire a most undue - nay, dangerous preponderance, and would have it in their power to wield a formidable weapon against the mercantile interests of other nations", but this did not stir the British government either. ${ }^{15}$

Despite all these discussions no action was taken against Mexico in 1859, one of the reasons being Spain's involvement in a dispute with Morocco which was not resolved until April 1860. It has been suggested that this engagement satisfied Spain's need to enhance its prestige in the world, for the time being at least, and this is perhaps why the government decided to settle its differences with Mexico. This was achieved through negotiations in Paris between the Spanish Minister, Alesandro Mon and Almonte, the Mexican Minister for the Conservative government, which resulted in the Mon-Almonte Treaty signed on 26 December 1859 and ratified on 25 January 1860. It provided for the prosecution of those responsible for the assassination of Spanish nationals in two separate incidents in 1856 , and for the payment of compensation to others who suffered damages at the same time. It was agreed that other claims, outside of these incidents would also be finalised in discussions between the two governments.

The political situation in Mexico had not improved, however, for the divisions in Mexico were fundamental and deep, and unlikely to be resolved easily. In January 1859

\footnotetext{
13 Ibid.

${ }^{14}$ Buchanan to Russell, 20 July 1859 and 24 August 1859. Quoted by Daniel Dawson, The Mexican Adventure, p.39.

${ }^{15}$ Letter from Mexico, printed in The Times (London), 3 January 1859.
} 
Zuloaga, the Conservative President in Mexico City, was ousted by his colleague, Miguel Miramon, who increased the pressure on the Juarez administration in Vera Cruz with strong military offensives against Liberal strongholds throughout the country. In July Juarez introduced a number of reform laws which included: nationalising Church property; separation of Church and State; exclaustration of monks; establishment of a civil registry for certificates of births, marriages and deaths; secularisation of cemeteries; and secularisation of public holidays. In reply Miramon pledged to champion "the interests of the Church, vigorously sustaining the prerogatives and independence of that institution."16 Against this background, early in 1860 England and France thought it would be appropriate to mediate between the two leaders to help establish a government that would be accepted by the entire nation. Edouard Thouvenel, successor to Walewski as French Foreign Minister, had suggested the formation of a Constituent Assembly to determine what form the new government should take, and to resolve all the difficulties facing the country. Capitalising on these ideas Collantes instructed his ministers in London and Paris to discuss with the respective Foreign Ministers how the three Powers and the United States, if they wished to be involved, could intervene in Mexico to achieve a stable government. He believed that just the news that such an intervention was to take place would be enough to give courage "to the honourable people" in Mexico to work towards establishing a government which would end forever "the spirit of rebellion that had caused so much damage in this unfortunate country."17

Russell's response to Collantes's proposal was that he would be prepared to consider any suggestions as long as the employment of material force was not considered in their execution, and this was to remain the policy of England throughout the negotiations. ${ }^{18}$ Thouvenel said that no decision could be made about action until the American Senate had voted on whether to ratify a proposed treaty between the United States and the Juarez Government in Vera Cruz, as this would naturally have an effect on

\footnotetext{
${ }^{16}$ Ralph Roeder, Juarez and His Mexico, p. 205.

17 Collantes to Mon and Isturiz, 18 April 1860. A.D., Vol. 7, pp. 211-213.

18 Isturiz to Collantes, 27 April 1860. Ibid., p. 213.
} 
what the European Powers decided to do. ${ }^{19}$ This point was expanded on by Collantes when he suggested to Russell that if England, France and Spain all adopted a strong policy it would show the United States that they were not prepared to tolerate their attitude of exclusion of European nations from the New World. He did not elaborate on what he meant by "strong policy", but a treaty between Juarez and the United States would be to the detriment of Europe, giving the United States more strength in its determination to exclude Europe from the Americas. Apart from these reasons, Collantes said that Spain was acting from humanitarian motives which would not let her see Mexico continue to be weakened by the prevailing anarchy in the country. ${ }^{20}$

The three governments finally agreed to act in concert to mediate between the two Mexican leaders, but circumstances did not admit of this being successful. One of the reasons was the continued outrages being committed against European nationals, which included murders and physical abuse, thefts and forced loans, and another was the change of each of their representatives in Mexico. Between March 1860 and May 1861 all three governments had to replace their Ministers for various reasons, and it was the observations of these new Ministers, based on very limited time to assess the situation, that led their governments to agree to intervene in Mexico in October 1861. In June 1860 the Spanish ambassador, Joaquin Francisco Pacheco arrived in Mexico to replace the consul who had been managing Spain's affairs. The British minister, Otway, had left Mexico in late 1859, and pending the arrival of the new minister, Sir Charles Wyke, British representation was maintained by George Mathew, Secretary of the British Legation in Mexico City. The Comte de Gabriac, the French Minister, had demanded leave from Mexico for some months for personal reasons, so a replacement had to be found for him also. De Gabriac's replacement, Dubois de Saligny, did not arrive until November 1860, and Wyke until May 1861.

\footnotetext{
${ }^{19}$ Mon to Collantes, 4 May 1860 . Ibid., p. 214.

${ }^{20}$ Collantes to Isturiz, 11 May 1860 . Ibid., p. 215.
} 
However, by August 1860 the British Government had lost patience with the two parties in Mexico and Russell wrote to Mathew that Her Majesty's Government could no longer tolerate the outrages committed against British subjects and the continual forced loans imposed by the Miramon Government. He was therefore to withdraw the legation from Mexico City and break off relations with Miramon. He was not to go to Vera Cruz, though, as Britain did not wish to show any partiality towards the Juarez Government even though they had not been as "utterly regardless ... of the representations of Her Majesty's Government". This may only have been due to the presence of a British squadron off Vera Cruz, but Russell stressed that Britain would stay "aloof from both parties" until a government with some chance of stability was established. ${ }^{21}$ This action was applauded on behalf of British residents in Mexico by a correspondent from Mexico City on 15 October 1860 , confirming the deeds of the Miramon Government and adding that the Constitutional Party of Juarez was the only one with whom British nationals could feel secure. ${ }^{22}$ Pacheco on the other hand, had gone to Mexico City on his arrival in Mexico and decided that Miramon was more worthy of support than Juarez. In August he had presented his letter of credence to Miramon.

In November Russell wrote again to Mathew saying that both Britain and France had assured President Buchanan that they did not intend interfering by force in Mexico, although he appeared to be wiping his hands of the whole question when he went on to say that if the United States did not act with Europe they could handle the problem themselves. "Let the Americans interfere by force if they will, and put up President Juarez if they like and let our merchants have freedom of trade and passage."23 This was, however, consistent with the developing policy of the British Government towards the United States at that time. As seen above, by the late 1850s the opposition of the British Government to the expansion of the United States in the Americas had begun to decline. Proposals for the abrogation of the Clayton-Bulwer Treaty of 1850, which

\footnotetext{
${ }^{21}$ Russell to Mathew, 24 August 1860. British and Foreign State Papers (State Papers). Vol. 51, 1860-1861 (London,1868), pp. 548-549.

${ }^{22}$ The Times, 13 November, 1860.

${ }^{23}$ Russell to Mathew (private), 1 November 1860 (copy). PRO: PRO 30/22/95 Russell Papers.
} 
represented a formal barrier to the expansion of the United States, were put forward by Foreign Secretary Clarendon in 1857. It was felt that public opinion in Britain would no longer support antagonism to the United States as this might affect commercial interests in the Americas. Any pressure to contain the expansion of North America could lead to war and pose a threat to commerce and to future interoceanic communication when a canal was built. ${ }^{24}$ This changing attitude was to be reflected in the negotiations that continued throughout 1860 and 1861 and culminated in the tri-partite intervention in Mexico.

There was, however, a contrast between the attitudes of the British government and Napoleon towards the expansion of the United States, and to European involvement in the Americas, the exclusion of which had been formalised in the Monroe Doctrine of 1823. While British ministers were afraid of antagonising the commercial interests of Britons, they also saw as inevitable the United States controlling the whole of the Americas. Malmesbury had stated this in 1858 , but Palmerston had made a similar comment late in 1857:

I have long felt inwardly convinced that the Anglo-Saxon Race will in Process of Time become Masters of the whole American Continent North and South, by Reason of their superior Qualities as compared with the degenerate Spanish and Portuguese Americans. $[\text { sic }]^{25}$

Napoleon was later to be accused of wanting to prevent this supremacy of the AngloSaxon race by forming a strong Latin Catholic barrier to the expansion of the United States. However, as we shall see he was more concerned with resolving the isolationist policy maintained by North America since as early as 1780 , which he saw as one of the most significant barriers to world peace.

Both the French and British governments, however, hoped their new envoys would be able to assist in resolving their difficulties with Mexico, but it was to be their actions and recommendations that led to the decision of the three governments to

\footnotetext{
${ }^{24}$ Kenneth Boume, "The Clayton-Bulwer Treaty and the decline of British opposition to the territorial Expansion of the United States, 1857-60", The Journal of Modern History, Vol. 33, 1961, pp.287-291. ${ }^{25}$ Palmerston to Clarendon (private), 31 December 1857. Quoted by Kenneth Bourne, ibid., p. 290.
} 
undertake an expedition to Mexico late in 1861. Saligny's orders on his departure from France had been to work with his English and Spanish colleagues to impose a truce and bring about a meeting of a Constituent Assembly, but Saligny decided on his arrival that he had no faith in anybody being able to regenerate Mexico, and he believed the country was doomed to perpetual civil war. ${ }^{26}$ In any case his instructions were out of date shortly after his arrival in Mexico because Juarez's army defeated that of Miramon, and took over the capital on 25 December 1860. The day after Juarez's arrival in Mexico City Pacheco and several other foreign representatives, including the Apostolic Delegate and all the bishops, were expelled from the country for having supported Miramon. Saligny then took over responsibility for Spanish affairs.

In the months ahead Saligny was to play a crucial role in determining the course of events and influencing the policy of his government towards Mexico, and he was perhaps the most significant of those others who, I will show, must be held responsible for the controversy that has persisted regarding Napoleon's intentions in Mexico. For this reason, it is valuable to appreciate the situation he was inheriting from his predecessor, de Gabriac, and the character and background of Saligny himself. All these issues raise questions about the attitude to Mexico in that era, and Saligny's choice may also reflect the fact that Mexico in 1860 was not seen as a major problem, or one that was likely to involve armed forces and prolonged occupation. According to Christian Schefer his posting was originally to be for a few months to allow de Gabriac to take leave, and as the position was only to be temporary not many candidates would have been attracted. ${ }^{27}$

De Gabriac himself had made an unfavourable impression on all his colleagues in Mexico and, according to the American minister, Forsyth, was an "open and active partisan of the Zuloaga party", spending "a large part of his time daily [sic] in the

\footnotetext{
${ }^{26}$ Saligny to Serrano, 1 December 1860. A.D., Vol. 7, 1862, pp. 243-245.

${ }^{27}$ Christian Schefer, La Grande Pensée, p.64. Schefer was professeur à l'école des Sciences Politiques and wrote on French colonialism, this being his only work on the Second Empire. Others were related to colonial policies and activities of the July Monarchy and the Third Republic.
} 
Palace", and dreaming of a "European protectorate" and monarchy for Mexico. ${ }^{28} \mathrm{He}$ was also described as a "restless and irresponsible intriguer" who "provided a conspicuous example of the latitude that diplomats of his stripe allowed themselves in out-of-the-way comers of the service like Mexico."29 This observation would seem to be supported by reports of the actions and attitude taken by de Gabriac, and the subsequent actions of Saligny and Wyke will be seen in a similar light. In 1863 a French resident of Mexico for fourteen years, a M. Schlœsing, condemned the behaviour and personalities of de Gabriac and Saligny to General Bazaine who had just taken command of the French expeditionary forces. He wrote of de Gabriac:

Pendant que M. de Gabriac se faisait partisan [sic] contre les intérêts de ses nationaux, ces derniers protestaient énergiquement contre ses actes auprès du gouvernement français. À la coupable condescendance de ce ministre ... sont dues les exactions répétées qui se sont produites sous la forme de contributions extraordinaires sur le capital des étrangers, et contre lesquelles la France proteste si justement aujourd'hui. M. de Gabriac a été le principal agent de la chute du gouvernement modéré de M. Comonfort: sur lui retombe la responsabilité des trois années de révolutions du commencement de 1858 à la fin de 1860 , celle des excès commis par la réaction et celle des représailles dont peuvent avoir usé les partisans de la Constitution après leur triomphe. ${ }^{30}$

This last accusation seems rather incredible, but it serves to illustrate that de Gabriac was not following the politics of his own government, as the retrograde policies espoused by the Zuloaga government, particularly in relation to freedom of religions, were in opposition to those being introduced in France by Napoleon III.

Dubois de Saligny was to prove an even more controversial diplomat than de Gabriac, and his choice as Minister is both interesting and puzzling. Roeder sheds some light, however, when he describes Saligny as "an even more portentous specimen of the partisan and irresponsible diplomat that flourished so freely in Mexico, and as a consummate example of the license that the genus had come to enjoy with time and

\footnotetext{
${ }^{28}$ Report of the retiring American Minister in Mexico in 1859. Ralph Roeder, Juarez and His Mexico, p. 190. ${ }^{29}$ Ralph Roeder, ibid., p. 191. Although Roeder does not elaborate on this observation it is possible to conjecture that Ministers at such a distance from their governments with extreme delays in communication, were either hesitant in their actions from insecurity, or alternatively acted with supreme confidence, as Roeder implies, and were prepared to make momentous decisions without reference to their governments first.

$30 \mathrm{~J}-\mathrm{E}$. Schlosing to Bazaine, 14 October 1863. Paul Gaulot, L'Expédition du Mexique, Vol. 2, pp.425-426.
} 
impunity." 31 His observation presents an intriguing picture of how Mexico might have been regarded by foreign governments, for its long history of instability would have made relations with the country difficult and inconsistent, at the very least. This would then perhaps explain a certain lack of interest in how their agents operated there, and the comparative freedom they may have had in handling affairs. It might also explain the otherwise inexplicable appointment of someone like Saligny for his career in the diplomatic service did not make him an obvious choice. From 1831-1839 he had been in Hanover, Athens and Washington and was then Chargé in the independent Republic of Texas until its annexation by the United States in 1845. After this he had no post until sent to the Hague during the Second Republic. In 1851 he was recalled, possibly because of his Orleanist connections, and remained without assignment until called on to go to Mexico. He is reputed to have sought out influential people to help him get another position in the diplomatic service, but was obviously unsuccessful, for whatever reason. He had befriended the Duc de Morny, a half brother of Napoleon III who was very influential, and it is possible that he may have been recommended by him. ${ }^{32}$ Apart from apparently also being supported by de Gabriac there seems to be no other reason for his selection.

Before leaving France, Saligny had requested that because of the distance of Mexico from Europe, and the delay in communications, both he and the new British Minister be authorised to take, in concert, initiatives prompted by unforeseen circumstances $^{33}$. This was to prove a portent of his controversial behaviour in the months and years ahead, when he took many initiatives claiming they were in accordance with the Emperor's wishes. The role played by Saligny in the Mexican campaign presents some problems, because the influence he exercised on the Emperor to accept his view of the situation in Mexico over those of the military commanders is out of proportion with his background and earlier career. It will be seen, however, that the

\footnotetext{
${ }^{31}$ Ralph Roeder, Juarez and His Mexico, pp. 276-277. Roeder made use of countless Mexican sources, as well as many European ones, in his study.

32 Christian Schefer, La Grande Pensée, p. 64.

${ }^{33}$ Ibid., p. 67.
} 
campaign proved to be far more complicated than Napoleon anticipated, and it was perhaps because Saligny had been longer in Mexico than his commanders that Napoleon decided his opinions had more validity. Napoleon eventually realised he had been badly served by Saligny, but not until the expedition was late into its second year.

It was not long, however, before the Mexicans at least had cause to complain of the behaviour of Saligny, although it would appear that little regard was to be paid to those complaints in Paris. In April 1861 Andrés Oseguera, the First Secretary of the Mexican Legation in Paris, wrote to the Duc de Persigny, now Minister of the Interior, to gain support for the new government in Mexico. The Mexican people, he said, felt they had nothing to fear from the politics of the Emperor because his system "was the happy combination of order, justice, progress and a genuine liberty", to all of which the new Mexican Government aspired. It wanted to introduce civil and religious liberty and reduce the power of the Church in Mexico, which had so often interfered with past governments and dominated the country with its fanaticism and "the bribing of the army with its excessive wealth." He continued:

si pendant ces trois dernières années de guerre sanglante le gouvernement actuel du Mexique est parvenu à conquérir pour le pays les précieuses libertés que la France possède, et veut après la victoire du droit, que l'abolition de la mainmorte soit un fait; ce même gouvernement ne saurait comprendre que le Ministre de France lui soit hostile, lorsque la politique impériale et les idées napoléoniennes luttent aussi bien en France, en Italie qu'au Mexique contre le mauvais vouloirs et les conspirations souterraines des hommes du passé et de l'ultramontanisme universal. ${ }^{34}$

Because of this affinity the Liberal government felt it had with France, Oseguera said it was difficult to understand why Saligny was behaving in a hostile manner towards it. He referred to an incident when the Juarez government had ordered a search of the Convent of the Sisters of Charity for "money and valuables concealed there in violation of the law nationalizing Church property." The Spanish Sisters had appealed to Saligny, as the Spanish representative, for protection, although there was no intimidation involved during the search. Saligny had complained on behalf of Spain, and then on behalf of

\footnotetext{
${ }^{34}$ Oseguera to Persigny, 8 April 1861. AMAE: CP Mexique, Vol. 54.
} 
himself and his government, threatening not to renew relations with the government on the basis that the Sisters of Charity were under the Emperor's protection throughout the world - which they were not. ${ }^{35}$ Roeder commented that Saligny's "position was weak" because he had been forbidden to interfere in any internal affairs, and if he had been asked to show "the imperative orders under which he claimed to be acting, he would have been hard put to attribute them to the French Government." 36

There seems to be no response from Persigny or Thouvenel to this letter, but Saligny's ensuing reports did not help the cause of Juarez with the French government. In March he wrote to Thouvenel that foreigners, particularly the French and the Germans, were being attacked continually in the streets of Mexico City, and when the government finally organised a police force to control the "assassins", attacks began to occur on the roads out of the city. ${ }^{37}$ At the end of April he reported that there was disagreement among the various parties about what kind of government was appropriate for Mexico and claims of the ineffectiveness of the constitution of 1857 that was supposed to save the country. He continued with the following observations and suggestion to his government:

Dans l'état d'anarchie, on pourrait dire de décomposition sociale, où se trouve ce malheureux pays, il est bien difficile de prévoir la tournure que prendront les événements. Une seule chose me paraît démontrée, s'est l'impossibilité de rester dans le statu quo.

Tout indique que nous touchons à une nouvelle révolution. Dans cette situation, il me parait absolument nécessaire que nous ayons sur les côtes du Mexique une force matérielle suffisante pour pourvoir, quoi qu'il arrive, à la protection de nos intérêts. ${ }^{38}$

Saligny followed this recommendation with a request that he be given extraordinary powers, and be authorised to take, on his own responsibility, any action dictated by circumstances. He requested naval reinforcements be sent which would be responsible to him, and with them he would be able to make Mexico respect the rights of foreign nations and end the abuses being committed in the country. To support his

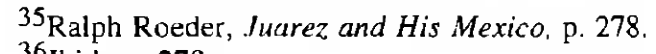

36 Ibid. p. 279.

37 Saligny to Thouvenel, 15 March 1861. A.D., Vol. 5, 1862, pp.119-120.

${ }^{38}$ Saligny to Thouvenel, 28 April 1861 . Ibid., p.121.
} 
recommendation Saligny made a broad observation that all Spanish American Republics had similar histories of successive revolutions. To end this cycle, any violation of the Rights of Man needed to be suppressed immediately, otherwise the Powers, after useless negotiations would be compelled to undertake distant and fruitless expeditions, because at the moment of their arrival the culpable government would have disappeared and been replaced by two or three others. ${ }^{39}$

Yet it has been seen in the letter of Oseguera that the Mexican government aspired to all the liberal policies espoused by France, and when the Constitution of 1857 was drafted, the Constitutional Committee said: "Two principal sources serve to inspire that political code: for the declaration of the rights of man, the doctrine [is] that of the French Revolution of 1789 , and for the political organization of the Republic [it is] the Constitution of the United States." 40 It might be recalled that the first article of the French Constitution of 1852 stated, "The Constitution recognizes, confirms and guarantees the great principles proclaimed in 1789, which are the basis of the public law of the French people", and these were, for example, public liberties, legal equality and property rights. ${ }^{41}$ Saligny, however, would not have been influenced by such comments, and he concluded the above despatch to Thouvenel by recommending that he seriously consider the idea of establishing a monarchy in Mexico as it was the only system capable of bringing an end to the abuses being committed, and to make the country respect the rights and dignity of other nations.

Saligny had little confidence in the Juarez administration, believing its position to be precarious, so he began to press for settlement of the French claims he had discussed with the government in March. He gave the government until 11 June to repay the money, but on 12 June Leon Guzman, the Foreign Minister, said although the government wished to fulfil its obligations, it was impossible to repay one of the claims as there was no money in the treasury. He promised, however, to have the money from

\footnotetext{
${ }^{39}$ Saligny to Thouvenel, 7 May 1861 (r. 30 June). AMAE: CP Mexique, Vol. 54.

${ }^{40}$ Wilfred Hardy Callcott, Church and State in Mexico, p. 282

${ }^{41}$ Alain Plessis, The Rise and Fall of the Second Empire (Cambridge, 1985), p. 12. Originally published in French in 1979.
} 
another, the Penaud convention, by 15 June. Saligny did not believe him and advised Thouvenel the French Government should make preparations to press their claims by force if necessary, because he felt Mexico was trying to buy time to avoid its responsibilities. ${ }^{42}$ He reported in July that the government refused to repay the Penaud convention, so he reiterated his conviction that force was the only way to make the government fulfil its obligations to France. ${ }^{43}$ An observer, however, accused Saligny of being an agent provocateur, saying that "the government had approached the creditors of the French Convention with an offer of pledges and promissary notes secured by Church property, which they were inclined to accept; but on consulting their Minister [Saligny], they were advised to refuse any settlement." 44

While Saligny was condemning the Mexican government and accusing it of deliberately avoiding its responsibilities, Mathew wrote more perceptive observations of the situation to Russell, based no doubt on his rather longer time in Mexico. He thought Juarez was "an upright and well-intentioned man", but not strong enough to handle the present crisis. In addition, the fact he was an Indian put him at a disadvantage with the Spanish sections of society and with those of mixed blood. The main hope for Mexico, Mathew believed, was for a prolonged period of peace to allow for "the development of constitutional principles, and for the gradual enlightenment of the people." The only chance for this to occur was if England and the United States supported the Government, or "principles of government" by a protective alliance or "by the declaration that no revolutionary movements would be permitted in any of the seaports on either ocean". Mathew commented further on the deplorable state of the country's finances, saying that without the consent of the various States the government could not raise taxes, and despite the possession of "great internal wealth" Mexico's finances had been exhausted by the last period of war. The income the government did have access to could only meet, at present, less than half its required expenditure. Although Church property had been nationalised and much of it sold, most of the proceeds had paid debts incurred by

\footnotetext{
${ }^{42}$ Saligny to Thouvenel, 12 June 1861. A.D., Vol 5, 1862, pp. 121-122.

${ }^{43}$ Saligny to Thouvenel, 5 July 1861 . Ibid., p. 123.

${ }^{44}$ Ralph Roeder, Juarez and His Mexico, p. 346.
} 
the war, while rumours calculated "to prevent the restoration of confidence, and the consequent investment of money in the purchase of nationalized property", had reduced the expected income to the government. ${ }^{45}$

These contradictory views would have confused the French and English govemments if read together, but Sir Charles Wyke arrived in Mexico in May and his attitudes and politics were to prove far different to those of Mathew, and somewhat similar to Saligny's. Unlike Saligny, Wyke had had several years experience in Central and South American countries, so his choice as minister in Mexico is logical. It may have been, though, that he came with preconceived ideas about the people and the situation in Mexico because he was to be very quick in summing up the situation and insisting that strong action was required on the part of his own government. His role in Mexico was to prove almost as controversial as Saligny's, although not as destructive, and his and Saligny's reports were the catalyst for their governments to intervene in Mexico.

Wyke left England on 2 April in receipt of lengthy instructions from Russell regarding both Britain's policy towards Mexico, and demands for Mexico to meet its international obligations. He was to advise the Mexican Government that Britain's policy was one of non-intervention and that they only wished to "see Mexico free and independent, and in a position to regulate civil administration of the country, to maintain internal peace, and to discharge its international duties without the intervention of any foreign Power whatever."46 Russell felt sure that "such assurances" would encourage the Mexican Government to accept any advice that Wyke had to offer as being impartial. He went on to caution Wyke about becoming involved in the differences between the various parties in Mexico:

A British Minister can never safely interfere in such matters; but as the representative of a country possessing liberal institutions, and therefore desiring to see other nations enjoying the same blessing, he will always be looked upon with respect and will have more real influence for good in

\footnotetext{
${ }^{45}$ Mathew to Russell, 12 May 1861. State Papers Vol. 52, 1861-1862, pp. 251-252.

${ }^{46}$ Russell to Wyke, 30 March 1861. Ibid., pp. 237-238.
} 
proportion as he keeps aloof from the factions or disputes of rival parties in the State. ${ }^{47}$

Wyke's first duty was to demand reclamation for British bond-holders under an agreement that had been signed by Juarez's Government in Vera Cruz two years earlier. The bond holders had also lost money stolen from the British Legation by Miramon's Government, and Britain would not allow Juarez to deny responsibility for this. If he did, Wyke was at liberty to refer "quietly" to the presence of British ships of war on the Mexican coasts, leaving the Mexican Government "to infer that those ships are available for your support if your just demands should be rejected, or if the engagements entered into with you should be disregarded." $48 \mathrm{He}$ was also to use every opportunity to emphasise the need to develop the country's resources thereby providing the means of covering the government's own expenses as well as its foreign debts. In addition he was to offer advice regarding the exercise of religious freedom in Mexico - the only question in international politics on which Britain felt authorised to offer an opinion. Wyke was reminded that the British Government did not seek in Mexico or any other part of the world exclusive political influence or commercial advantages that she was not prepared to share with other nations. ${ }^{49}$ This then was Britain's policy, fairly clearly stated, and it will be seen that it differed very little from the policy of Napoleon III. It was the implementation of the respective policies, by their representatives in Mexico, that later made it appear the policies were in fact different.

Wyke was not very long in Mexico before he came to very different conclusions to those of Mathew about the Mexican Government and its ability to meet its foreign obligations. As far as he was concerned the government had either destroyed Church property or dissipated the money from its sale without taking advantage of it to pay its debts. ${ }^{50}$ It therefore had to be coerced to pay them, and one way to do this was by using naval forces against the ports on both coasts of the country "when the moral effect

\footnotetext{
47 Ibid., p. 238.

48 Ibid., p. 241.

${ }^{49}$ Ibid., p.242.

${ }^{50}$ Wyke to Russell, 27 May 1861. Ibid., p. 255.
} 
produced would equal the material pressure, and ensure prompt compliance with any conditions which we might choose to impose."51 Wyke had been influenced in his opinion by a Captain Aldham who had been in Mexico or thereabouts for three years. Aldham's view was that the Mexicans were very adept at "evading their engagements" and it was time to use coercion to show Britain was not going to allow Mexico to continue "to set every principle of justice at defiance with impunity." 52 Wyke believed a show of determination by Britain would receive the respect and support of the Mexican people. Historian Ralph Roeder commented that Wyke brought "to the diagnosis of the organic troubles of Mexico ... the peremptory judgement of the bailiff, the diplomacy of a commercial traveler, and the impatience of a vigorous invalid." 53

It would be fair to say that it took neither Wyke nor Saligny very long to consider themselves completely au fait with the politics of the country, the abilities and motivations of individual personalities both in the government and other parties, and with the character of the Mexican people. How justified they were in their opinions is open to debate, but it is obvious that the opinions of both were taken seriously by their respective governments. In July they were to be provided with a reason to call on their governments for an intervention, when the Mexican Congress issued a decree which included the suspension of payment of foreign debts for two years. Wyke had a prolonged correspondence with Manuel Zamacona, the Mexican Føreign Minister about this decree and was scathing in his criticism of it as "a gross violation of [Mexico's] most sacred obligations towards other nations."54 Zamacona responded that this was not the case, that it was due "solely to the force of circumstances, which have rendered it morally and physically impossible for the nation to continue making those payments which have hitherto been made by means of the most strenuous exertions." The government, he said, was in a situation where it had only two choices: "either to respond to public opinion by adopting the only existing means of preserving order and reorganizing the

\footnotetext{
51 Wyke to Russell, 25 June 1861 (r. 29 July). Parliamentary Papers: Correspondence relating to affairs in Mexico (Parliamentary Papers) (London, 1862), Part 1, p. 21.

52 Ibid.

${ }^{53}$ Ralph Roeder, Juarez and His Mexico, pp. 322-323.

${ }^{54}$ Wyke to Zamacona, 19 July 1861. State Papers Vol. 52, p. 297.
} 
whole administrative system, or to look quietly on and leave society to become an easy prey to the prevailing anarchy." 55 Peace, order and administrative reform would be impossible to achieve if the government had to continue to expend nearly all its income on servicing the national debt. In effect Mexico was asking for the support and understanding of its creditors while the government embarked on the regeneration of its country. Suspension of payments to foreign nations was to be a temporary exercise to allow time for a solid base to be established for regeneration.

Wyke, however, could see no justification for Mexico taking this step without prior consultation with its foreign creditors and, rather pompously, I believe, proceeded to liken Mexico's reasons for its action to the justification of a starving man, who had stolen a loaf of bread claiming that

imperious necessity impelled him thereto ... ; but such an argument cannot, in a moral point of view, justify his violation of the law, which remains as positive, apart from all sentimentality, as if the crime had not had an excuse. If he was actually starving, he should have first asked the baker to assuage his hunger, but doing so of his own free will, without permission, is acting exactly as the Mexican Government has done towards its creditors on the present occasion. ${ }^{56}$

He then added, "for reasons so evident that I will not now advance them", he thought that the intended action would in fact aggravate the difficulties facing the government rather than provide relief. The following day he went on to advise that spoliation was not the answer, and what was needed was

a determination to make every sacrifice, and incur every privation, with a view of maintaining your honour and fulfilling your engagements. This determination once adopted and manfully put in practice would at once inspire confidence and rally round you those whose sympathies you now appeal to in vain, because they doubt from past experience both your prudence and your sincerity. 57

Wyke concluded with a declaration that unless the Decree was withdrawn in forty eight hours he would suspend all correspondence with the Mexican Government until he received further instructions from his own government.

\footnotetext{
55 Zamacona to Wyke, 21 July 1861. Ibid., pp. 298-299.

56 Wyke to Zamacona, 22 July 1861. Ibid., p. 305.

${ }^{57}$ Wyke to Zamacona, 23 July 1861. Ibid., p. 307.
} 
Zamacona made a final attempt to convince Wyke that the Mexican Government was not disavowing its obligations, whether incurred by previous governments or not, but merely seeking a suspension of payments for a given period of time. The Decree would actually provide a greater security for creditors, he said. The government had almost concluded an agreement with some of the foreign creditors in the country, with guarantees regarding maintenance of their present rate of interest, but it could not be finalised because Wyke refused to sanction it, as Saligny had done earlier with the French creditors. Zamacona then rejected the aptness of the simile that Wyke had used about the starving man and the stolen loaf, as well as the accusation that his government was committing further spoliation with this decree. He felt instead that the action of the government was

rather that of a father overwhelmed with debts, who, with only a small sum at his disposal, scarcely sufficient to maintain his children, employed it in the purchase of bread instead of in the payment of his bills. Were Her Britannic Majesty's Representative a member of the family, would his Excellency be eager to qualify his father's conduct by the name of spoliation? 58

Wyke was unmoved by this and immediately wrote to Russell saying that things would continue to get worse while this "dishonest and incapable Administration" remained in power. It was therefore essential that Great Britain "put a stop, by force if necessary, to its present state of anarchy". He then dismissed any possibility of sincerity on the part of the Mexican Government:

From the tone of their notes to me anybody not on the spot would imagine that dire necessity had alone compelled them thus to act, whereas in reality $6,000,000$ of hard dollars have actually passed through their hands within the last half year, to say nothing of the immense amount of church property in this district alone which has been dissipated in a manner, according to public rumour, utterly discreditable to the members of the Government. 59

To support his belief that this administration should be changed, Wyke mentioned the existence of the Moderate Party which, though presently "cowed by the two opposing ultra factions," would emerge, if supported by foreign intervention, and form a stable

\footnotetext{
${ }^{58}$ Zamacona to Wyke, 25 July 1861 . Ibid., p. 309.

${ }^{59}$ Wyke to Russell, 26 July 1861 (r. 29 August). Ibid., p. 294.
} 
and reliable government. Two days later he wrote that things were going from bad to worse and the government was now "generally detested". There were, he said, various conspiracies in train against the government, including one to propose ex-president Comonfort to replace Juarez with support of a party in the capital. ${ }^{60}$ Finally, on 30 July Wyke wrote to Zamacona that he was suspending relations with Mexico because his government had "dared to issue [the Decree] without consulting with me as the Representative of that Power which was the other Contracting Party to a Convention which said Decree shamefully violated." He went on to say that the government had possessed ample resources to meet its obligations and it was only its "wilful recklessness and want of common prudence" that had got it into the position that led it to repudiate its obligations, which would only aggravate its poverty. ${ }^{61}$

Why was Wyke so ready to dismiss the seemingly sincere approaches of the Mexican Government? He offers no proof other than "public rumour" to justify his claim that the Government had frittered away what money was available to them, and though he had been in the country for only a few weeks he felt qualified to dismiss the reasonable explanation Mathew had offered to Russell for the shortfall in expected revenue from the sale of Church property. Wyke used the anarchy and lack of order prevailing in the country as further proof that Juarez's Government was weak and ineffective, when perhaps it may have been better to support this government, which was making an open declaration about its position and its intentions for the country while asking for the understanding and support of other nations. Wyke's views, however, were shared by Saligny at this time, although the two were to become bitter rivals once the intervention began. Zamacona had written to Saligny, as he had to Wyke, acknowledging the difficulty the government would have of rising above the actions of previous regimes, but asking that it be judged on its own merits because of its determination to carry out the administrative reorganisation of the country. ${ }^{62}$ Saligny

\footnotetext{
${ }^{60}$ Wyke to Russell, 28 July 1861 (r. 29 August). Parliamentary Papers Part 1, p. 51.

${ }^{61}$ Wyke to Zamacona, 30 July 1861 (Inclosure Wyke to Russell, 8 August, r. 29 September). State Papers Vol. 52, pp. 333-334.

${ }^{62}$ Zamacona to Saligny, 21 July 1861. AMAE: CP Mexique, Vol. 55.
} 
was no more receptive than Wyke, and when he wrote to Thouvenel enclosing a copy of this letter he, too, focused on the appalling state of the country and advised he had broken off relations with Mexico. This rupture, Saligny claimed, had led the vast majority, "if not almost all" of the Mexicans to look forward to a war which they hoped would lead to a better solution to the country's troubles. He added that, with few exceptions, the French population in Mexico was also anxious for the French Government to take strong action.

Saligny seemed determined that Juarez's government should be discredited, for he warned Thouvenel against the special envoy that it was sending to Paris and London to explain, and ask for acceptance of, its plans for reform and financial reorganisation. $\mathrm{He}$ said categorically that nobody in Mexico, "beginning with the administration", took seriously these so-called imaginative plans put forward by a desperate government whose only aim was to find an excuse to get hold of the money already put aside to pay its foreign debts. ${ }^{63}$ And his words bore fruit, for when, four days after receiving this dispatch Thouvenel was approached by Juan Antonio de la Fuente, the Mexican Minister in Paris, he refused to hear the explanations of the July Decree offered by the Mexican government. Instead he told de la Fuente that the French Government entirely approved the conduct of Saligny, and that with England they had already given orders for a squadron of ships from the two nations to demand due satisfaction from the Mexican government. Following this meeting de la Fuente suspended diplomatic relations with France. ${ }^{64}$

De la Fuente, however, had some interesting observations to make on the behaviour of both Saligny and Wyke since their arrival in Mexico. According to reports from his government the views expressed by these Ministers were not based on information gathered from their own observations and could therefore be challenged. Zamacona had written that neither of them had been outside the capital to gauge the

${ }^{63}$ Saligny to Thouvenel, 27 July 1861 (r. 30 August). AMAE: CP Mexique, Vol. 55. $64_{\text {A.D. }}$., Vol. 8, 1862, p. 146. 
reactions to the government in the countryside or the various States, and their unfriendly attitudes towards the government had caused agreements made with some of the parties involved in the French and English conventions to fall through. Furthermore, the reaction of Saligny to the approaches of Zamacona of demanding the settlement of one particular French convention, had been both menacing and insulting, rendering any chance of friendly agreement impossible. Zamacona added that Saligny had received members of the reactionary faction in his home and had been in contact with many who represented "retrograde principles". Wyke also had become involved with these groups, whose politics were completely contrary to the principles of his own government. Being influenced in their view of Mexican politics by "an exceptional and eccentric minority", the two Ministers predicted as inevitable the rising of a neutral party which did not in fact exist. 65

These opinions were rejected without consideration by both the French and British governments, as can be seen in their instructions to Saligny and Wyke. The day after the visit of de la Fuente Thouvenel wrote to Saligny advising that the Government entirely approved of his actions and his decision to sever relations with Mexico. He spoke of the hope that the government had entertained that the new Administration would honour its obligations to France, and how that hope had increased when Saligny told them of the convention signed with Zarco in March. Now that they could see the Mexican government had no intention of honouring its obligations, Saligny was to demand the immediate retraction of the July Decree and insist that commissioners be placed in the ports of Vera Cruz and Tampico to collect the customs duties to pay the foreign conventions. If they refused he was to remove the entire French Legation from Mexico City. 66

In the meantime Saligny added further fuel to the determination of his government to take firm action, but at the same time alienated his fellow Frenchmen in Mexico. In

\footnotetext{
65 Ibid., p. 148.

${ }^{66}$ Thouvenel to Saligny, 5 September 1861. A.D., Vol. 5, p. 125.
} 
August a large crowd gathered to welcome General Ortega returning from a successful battle against the Conservative army, and several days later Saligny reported to Zamacona that an attempt had been made against his life during the demonstration. He claimed that a bullet had been fired and hit a post near where he was standing at his residence, but there were no other witnesses and no mark could be found on the post to verify his claim. He also made other claims of threats against French nationals which could not be corroborated, but this did not stop him. Roeder concluded,

Far from representing the French colony, which was predominantly Liberal in its sympathies, he was denounced even by its conservative members as a menace to their interests, and the leading bankers and merchants proposed to draw up a representation against his interference and war-mongering. 67

These comments are supported by the long-time French resident, Schloesing, in his memorandum to Bazaine, in which he remarked that this incident was not taken seriously by "any one of our impartial compatriots", who considered that Saligny had made "the Mexican question a question of personal pride." He observed further:

Je ne crains pas de l'affirmer en toute conscience: le gouvernement de l'Empereur a été trompé, depuis plusieurs années, sur la véritable situation du Mexique; les renseignements de M de Gariac portaient le cachet de la partialité la plus manifeste, ceux de M de Saligny respiraient la passion et la vengeance. 68

It can be seen that Saligny's behaviour was considered in Mexico as controversial and misleading before the intervention began, and it was to continue in this vein for two years.

Similar instructions to those from Thouvenel were sent to Wyke who was told that he was to leave Mexico if the demand for control of the customs ports was not agreed to, as continuing negotiations appeared useless. ${ }^{69}$ Russell's response to Wyke regarding the July Decree and his correspondence with Zamacona, showed that he accepted without question Wyke's assertion about the Mexican Government squandering 6,000,000 dollars in six months. He also rejected Zamacona's claim that the government was

\footnotetext{
${ }^{67}$ Ralph Roeder, Juarez and His Mexico, pp. 346-347.

${ }^{68}$ Schlosing to Bazaine, 14 October 1863 . Paul Gaulot, L'Expédition du Mexique, pp. 425-426.

${ }^{69}$ Russell to Wyke, 21 August 1861. Parliamentary Papers Part 1, p. 30.
} 
restoring order and pursuing administrative reorganisation, although his opinion was based solely on Wyke's limited acquaintance with the country:

[I]t is notorious that everyone of these assertions is directly the reverse of the truth. It is well known that life and property are nowhere safe, not even in the streets of the capital; that the Administration is as corrupt and as reckless of any interests but their own personal advantage as any that has heretofore governed in Mexico; that great anarchy and disorder prevail in all the departments of the Government. ${ }^{70}$

Her Majesty's Government could not accept any of these excuses for what had happened to their subjects in Mexico so Wyke was again instructed to leave Mexico if the demands in Russell's letter of 21 August were not met. The English and French governments agreed that they would send some naval forces to give them any support they needed.

The Spanish government was also considering taking action against Mexico, on the basis of reports from Saligny of the constant persecution of Spanish nationals. It is strange though that it waited until July to consider any action when its Minister, Pacheco, had been expelled the previous December. The Mexican Foreign Minister had written in February to explain that Pacheco had by-passed the Juarez Government - the legitimate government - on his arrival at Vera Cruz and proceeded to Mexico City where he had recognised the rebel, Miramon, as head of the Mexican Government. It was claimed that Pacheco's behaviour had in fact caused the civil war to be prolonged, and his expulsion for acting in opposition to the legitimate government was inevitable. It was pointed out, however, that the sentiments of the Juarez Government were directed only at Pacheco and not towards the Spanish Government with whom they were anxious to resume cordial relations by asking for a new Spanish representative to be sent to Mexico. ${ }^{71}$ The Spanish government, however, only demanded some compensation for Pacheco's expulsion and maintained Saligny as their representative.

It was the report of the Spanish Vice-Consul at Cuernavaca that the Mexican government was doing nothing to prevent the persecution of the Spanish, that caused

\footnotetext{
${ }^{70}$ Russell to Wyke, 10 September 1861. Ibid., p. 53.

71 Ministre des Relations Extérieure de la République Mexicaine to Collantes, 21 February 1861. A.D., Vol. 7 , pp. 284-286.
} 
Collantes to tell the Mexican government that if it did not do something to curtail these persecutions the Spanish government would be obliged to adopt measures to put an end to this state of affairs. ${ }^{72}$ Saligny negotiated with the Mexican government to obtain satisfaction for the expulsion of Pacheco and advised Spain that a special envoy was being sent to offer excuses for Pacheco's expulsion and to discuss Spain's claims against Mexico. This was to be de la Fuente, but as he made no attempt to see Mon, the Spanish Minister in Paris, to obtain an introduction to his government, Mon assumed that he had no intention of approaching the Spanish government at all. ${ }^{73}$ It is also possible that the dismissal of de la Fuente by Thouvenel was what prevented him from approaching Mon.

Although their earlier reports had convinced their governments of the need for firm action to be taken against Mexico, Wyke and Saligny both wrote at the end of August that coercive action on their parts would encourage the Moderate Party to form a more creditable government. Wyke advised Russell that the government had imposed a tax of 2 per cent on capital over 2,000 dollars as a further means of raising revenue because the Decree of 17 July had caused the merchants to decide not to remove their goods from the Custom House at Vera Cruz, thus denying the government the duties it had anticipated. Wyke claimed this had discredited the government even further and resulted in instability within the government itself. It was said that one of Juarez' generals, Ortega, was plotting to get himself elected president and that Comonfort was still intriguing with various State Governors to head a coalition to overthrow Juarez. Wyke concluded this dispatch by again asserting that "the respectable classes" thought a foreign intervention was the only means of saving the country, and that if France or Britain used coercive measures to seek redress

- then the moderate party may take courage and be able to form a Government which would afford some hope for the future; but without such moral support and assistance, they are afraid to move, and will remain the victims of the two contending factions, whose dissensions have already caused so much misery and bloodshed. ${ }^{74}$

\footnotetext{
${ }^{72}$ Collantes to Serrano, 9 July 1861. Ibid., pp. 289-290.

${ }^{73}$ Mon to the Spanish Chamber of Deputies, 7 January 1863. A.D., Vol. 10, 1863, p. 39.

${ }^{74}$ Wyke to Russell, 27 August 1861 (r. 29 September). PRO: FO 50/354.
} 
Saligny also predicted that if the European Powers did not intervene the perpetual civil wars and anarchy would result in an uprising by the Indians leading to "a racial war and ... the destruction of all social order." He anticipated that Mexico would go the same way as other Central American countries if Europe did not take advantage of the civil war in North America "to give to this country institutions more in harmony with the aspirations, ideas and needs of nineteen twentieths of the population."75 He suggested further that in the interests of France's honour, the expenses of the expedition to Mexico, if it were decided upon, should be added to the claims that France already had against Mexico.

By the time these last despatches from Wyke and Saligny reached Europe, discussions were well under way between the three governments on what might be the aims of an expedition, and how it should be conducted. Both Saligny and Wyke had mentioned the presence of a Moderate Party and this assertion, and their conviction about the popularity of a European intervention, were to have a decided effect on the development of the plans for intervention. More significantly it was their claims that led all three governments to believe that their proposed actions would enable them to recover what was due to them, and quite probably see a more reliable government installed. The difference was that each government gave this latter point a different degree of importance. Everything indicated that the three governments were equally anxious to take action against Mexico and see a new, stable government in place. Yet the negotiations over the next few weeks were to reveal subtle differences in their intentions. Most emphasis has been placed on what Napoleon III thought and did, and most blame for the outcome of the expedition laid at his feet. The roles played by the key people in both the Spanish and English governments, however, contributed significantly to the decisions made by Napoleon, as did those of the various representatives in Mexico. The period of negotiations was to be intriguing, as Spain suddenly became fired with a determination to act forcefully and quickly, and this also had a decided impact on the

${ }^{75}$ Saligny to Thouvenel, 28 August 1861 (r. 30 September). AMAE: CP Mexique, Vol. 55. 
direction the intervention took. The discussions on the aims of the expedition were protracted, but concluded with all three believing they were in agreement, when they were in fact very far from it. 


\section{(Ubapter 2}

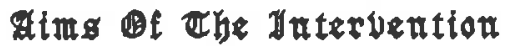

As a consequence of the reports from their Ministers, the French and English governments agreed on the need to take decisive action against Mexico, but before they could approach Spain to act with them, the Spanish government learned of their intentions and it seemed to be overcome with the desire to show it was Spain that had taken the initiative. Given the tardiness with which it had reacted to the expulsion of its Minister, Pacheco, Spain's precipitate action at this time is puzzling and the only explanation seems to be related to the internal political situation, as will be shown below. The discussions that ensued in the following weeks seemed to indicate that the three governments were in agreement on the need for a change of regime in Mexico, but in the final analysis both the Spanish and English Ministers were reluctant to put such proposals before their parliaments. Napoleon made suggestions about a monarchy, if it was wanted by the Mexicans, and these were verbally supported by his allies, but when they became public after the intervention began, the Spanish and English Ministers denied prior knowledge of his ideas. Russell's and Palmerston's position was influenced not only by concern over the anticipated reaction of the parliament but also by discussions with the American Minister, who warned against European interference on the American continent. These contradictory behaviours of the Spanish and English, and the early Spanish arrival in Mexico were to have far-reaching effects on what was to have been a combined expedition, and all three governments ultimately became suspicious of the others' intentions.

When Mon, the Spanish Minister in Paris learned the British and French governments were sending naval support to Mexico he sent a telegraphic despatch to Collantes saying the decision seemed to have been taken without regard to Spain. ${ }^{1}$ Collantes replied, in apparent disregard of Mon's despatch, that the Spanish Government

\footnotetext{
${ }^{1}$ Mon to Collantes, 6 September 1861. A.D., Vol. 10, 1863, p. 41.
} 
had resolved to act "energetically" and was sending a boat with instructions to the Captain-General of Havana, General Serrano, to act against either Vera Cruz or Tampico with all the land and sea forces at his disposal. Naval reinforcements were also being sent which would be enough to maintain the dignity of Spain. He went on to suggest that if England and France were agreeable to acting with Spain, the forces of the three Powers would join together "as much to obtain reparation for their injuries as to establish a regular and stable order in Mexico." If England and France refused, Spain would go alone, as the Spanish Government had been waiting for an opportunity, when it could not be accused of purely political motives, to act "vigorously" against Mexico and make its just reclamations. If the French did wish to act with Spain, Collantes said, similar instructions would be sent to his minister in London. ${ }^{2}$ Mon's cynical comment about the decisions conveyed in this despatch was that just a few hours elapsed between the reception of his own despatch and the resolution of the Government, "which demonstrates the zeal of the Spanish government."3 In the Spanish Cortes in 1863 Mon was highly critical of Collantes's apparent intention of claiming credit for initiating the idea of a tri-partite expedition, and as the negotiations progressed and the expedition got under way, other observers were also to question the motives of Collantes and the Spanish Government.

Regardless of Spain's claim to have taken the initiative, there did seem to be agreement at this stage on what needed to be achieved in Mexico. On receipt of Collantes's despatch Mon went to discuss with Thouvenel the Spanish Government's resolutions. Thouvenel told him the Spanish ideas were in complete agreement with those of the Emperor, and suggested the three countries should take control of the Custom Houses and that they advise Mexico of the need to establish a new government whose stability could be ensured with the help of the three governments. Thouvenel said he had already written to England with these proposals and had intended writing to Spain as well. ${ }^{4}$ Mon also had an informal discussion with the English Minister Lord Cowley,

\footnotetext{
${ }^{2}$ Collantes to Mon, 6 September 1861. A.D., Vol. 7, 1862, p. 290.

${ }^{3}$ Mon to Cortes, 7 January 1863. A.D., Vol. 10, 1863, p. 42

${ }^{4}$ Mon to Collantes, 9 September 1861. A.D., Vol. 10, p. 42
} 
in which a change of government in Mexico was discussed. Mon claimed that Cowley thought a monarchy was the most suitable government for Mexico, with which Mon agreed, adding, however, that he had no instructions regarding this from his Government. When commenting on this discussion to the Cortes in 1863, Mon said he did not believe anyone had been suggesting imposing a monarchy by force. Everyone believed that all the previous governments in Mexico had been impossible and "incompatible with a good regime"; that there was no government that had not been offended by Juarez; and that everyone knew that a strong power would have to be represented "by a person of high standing" who would be morally supported by Europe.5 The idea that a monarchy was probably the most suitable form of government for Mexico was agreed by the Ministers of all three governments involved in discussions about the intervention, but ultimately the Spanish and English Ministers were to deny that this was so, and again it was the demands of their internal political situations that dictated their behaviours.

The behaviour of the Spanish government at this time was controversial and contradictory and elicited both support and criticism within its own country. While the pro-government papers began protesting against the idea of a joint venture when Spain was strong enough to go alone, the Opposition paper, Contemporaneo, criticised the government for doing nothing when Pacheco, their Minister, was expelled from Mexico and only deciding to act when England and France suspended or broke off diplomatic relations. It added that although Spain's claims were greater than England's or France's it would be better to leave the problem to them rather than try and prove how strong Spain was. The author then proceeded to criticise Collantes for asserting that they were going to intervene in Mexican affairs and reorganise the State, and he asked what had happened to the principle of non-intervention. The only basis for interfering in the affairs of another country, he said, was if the problems there threatened the peace of their own nation. ${ }^{6}$ Collantes, however, continued to discuss the idea of a reorganisation in Mexico,

\footnotetext{
$5_{\text {Ibid. }}$

${ }^{6}$ Contemporaneo, 10 September 1861. Translation. PRO: FO 72/1009.
} 
and his despatch to Isturiz, his Minister in London, inviting England and France to join Spain if they wished, reiterated his belief that the presence of the combined forces would cause the Mexicans to realise the need to constitute a government which would provide internal security and sufficient guarantees to other nations. ${ }^{7}$

It was clear, though, that the Spanish Foreign Minister was determined that Spain should be in the forefront of any action against Mexico, and he sent to General Serrano the instructions referred to in his despatch to Mon. While he said there was absolutely no intention of intervening in the "internal discussions" of the republic, nor of supporting either of the warring factions, it is not clear whether this excluded giving what Collantes later called "moral support" to the honest men waiting for that support. He stated that it was the desire of the government to assemble all the resources possible on the coasts of Mexico, and if necessary on Mexican territory. Serrano was advised that England and France might join their forces with those of Spain but discussions might take some considerable time. In the meantime Serrano was to send his forces to the coast of Mexico and demand due reparation. If his demands were not met within twelve days he was to commence "necessary action to oblige them to submit to his demands."

When questioned on this action the Spanish government denied the extent of its proposed actions so when its forces landed in Mexico before the arrival of the British and French, it was natural that their governments should react with suspicion. Sir John Crampton, the British Minister in Madrid was asked to confirm with Marshal O’Donnell that orders had been sent to Serrano to occupy Vera Cruz and Tampico, as such an action seemed in conflict with Spain's stated desire to act with England and France. O'Donnell told Crampton that Spain intended to take action alone if England and France declined to join them. But he denied orders had been sent to Serrano to "take possession of Vera Cruz or Tampico, or to undertake any military operation against Mexico, [the idea] must have originated in a misapprehension, because he could assure me that no such orders

\footnotetext{
${ }^{7}$ Collantes to Isturiz, 11 September 1861. A.D., Vol. 7, 1862, p. 292.

${ }^{8}$ Collantes to Serrano, 11 September 1861. Ibid., pp. 293-297.
} 
had been given," Crampton added. All that had been done, O'Donnell claimed, was to make preparations to ensure they were ready to take action when the time came. ${ }^{9}$

These assertions by O'Donnell to the British, and similar ones to the French by Collantes, were later to be disputed, however, by Mon in his address to the Cortes in 1863. He confirmed that orders had been sent on 11 September 1862, if not to take possession of the ports, at least to take necessary coercive action if demands were not met. The order to suspend the expedition pending negotiations being settled with England and France was not sent until well after Serrano had departed Havana for Mexico. Mon claimed there had been five or six steamers leaving Spain for Havana between 11 September and the date of Serrano's departure, yet even by the time General Prim arrived in Havana to command the expedition, there had been no orders received to suspend the operation. 10 This precipitate departure of the Spanish was to have a considerable impact on the early stages of the combined operations.

What was the Spanish government's motivation in all this? Were its Ministers driven purely by the need to prove Spain's greatness at a time when its prestige was well out-stripped by that of England and France? If this were so, they were supported by certain sectors of Spanish society, judging by the calls in some papers for intervention in Mexico and for the establishment of a monarchy, and speculation on the recovery of Spain's former possessions in the area. However, Barrot, the French Minister in Madrid wrote to Thouvenel that as far as he could judge, the reason Spain seemed to be acting so quickly was not because the question itself was so urgent, or that they hoped to achieve better future relations with Mexico. It was rather to ward off expected serious attacks by Pacheco over the Government's handling of the Mexican situation, in the forthcoming session of the Cortes. Therefore this haste on the part of Spain was driven by the demands of internal politics more than by the hope of achieving in Mexico "a work of the future" (une cuvre d'avenir) . 11

\footnotetext{
${ }^{9}$ Crampton to Russell, 16 September 1861. Parliamentary Papers Part 1, p. 55.

10 Mon the the Cortes, 7 January 1863. A.D., Vol. 10, 1863, p. 45.

${ }^{11}$ Barrot to Thouvenel, 18 September 1861. AMAE: CP Espagne, Vol. 859.
} 
While Spain was initiating action, discussions had been taking place between France and England to clarify their aims and determine what their combined action should be. Although there was apparent agreement in many respects Russell and Palmerston were reluctant to put the opinions they expressed verbally to the French before their own parliament, which inevitably sent confusing messages to Thouvenel and Napoleon. I believe that it was the acceptance of Russell's and Palmerston's spoken views that led Napoleon and Thouvenel to believe England and France had similar aims in going to Mexico, yet when these aims became public Russell and Palmerston were quick to condemn Napoleon. Early in September Thouvenel had asked Lord Cowley, the English Minister, if Russell would be inclined to take advantage of the United States' preoccupation with its own affairs to recommend "the rival parties to take unto themselves a sovereign", and Cowley had remarked to Russell: "No doubt if Mexico would do this of her own free choice, it would be the best chance of restoring herself to a creditable position among the nations of the world." 12 Thouvenel then expanded the French ideas regarding Mexico in a lengthy despatch to the Comte de Flahault, now the Minister in London, outlining why it was no longer possible to negotiate with Juarez and why there was a need for a new government. He said that two things were important, firstly to obtain compensation from Mexico, and then to know that any new government would stay in power long enough to ensure that their demands were met. The experience both governments had had with the Juarez government since it defeated Miramon proved how powerless Mexico was to overcome alone the anarchy resulting from so many years of internal dissension. It was therefore "chimerical" to hope that another revolution would result in a power, both strong enough and universally respected, that would provide security for the country itself as well as for foreign nationals and their interests. He argued that as their main objective was the protection of their nationals and of commercial interests in Mexico, they would have more chance of achieving success if they endeavoured to prepare the way for the political reorganisation of Mexico. It was therefore essential that the manner in which France and Great Britain proposed to

\footnotetext{
${ }^{12}$ Cowley to Russell (Private), 5 September 1861. PRO: PRO 30/22/56, Russell Papers.
} 
intervene was determined in advance, and identical instructions given to their agents in Mexico. ${ }^{13}$

Discussion of these suggestions, between Flahault and Russell, seemed to reveal agreement on the need for a better government in Mexico, but that Russell was anxious about Spain's intentions there. Russell said the French and English governments were in complete agreement on the complaints against the Juarez Government and the need for something to be done. He had sent to Lord Palmerston a report from the board of the Admiralty regarding the forces needed to secure the fort of St Jean d'Ulloa, and was awaiting his reply. He commented to Flahault, though, that even if the three Powers agreed on what was to be done, England foresaw one difficulty as being insurmountable - that Spain would propose the persecution of Protestants in Mexico, and England could not possibly tag along behind a Power that would not practise religious tolerance. In summary, England would be more than happy to act with France, but could do so only with the aim of establishing a liberal and tolerant government. ${ }^{14}$ In making this latter comment, Russell may only have been wishing to ensure that the Spanish did not exercise their influence to enforce a return to a Conservative Catholic regime in Mexico, but Thouvenel and Napoleon could be forgiven for believing that Russell saw the establishment of a more stable government in Mexico as a principal aim of their proposed action.

Flahault commented on the importance Russell placed on the religious question, saying how careful an English Minister had to be in this regard. Any act of intolerance against Protestants by a Catholic in such a situation would elicit cries of condemnation and indignation from all corners of the country and in the parliament, therefore they could not expect the least modification of England's views regarding religious tolerance.

Cowley also broached this issue of religious tolerance with Mon, who replied that he thought those questions should be left to the Mexican Government. He also said Spain

\footnotetext{
${ }^{13}$ Thouvenel to Flahaul, 9 September 1861. AMAE: CP Angleterre, Vol. 720.

${ }^{14}$ Russell to Flahault (translation) in Flahault to Thouvenel (Private), 16 September 1861. AMAE: CP Angleterre, Vol. 720.
} 
had no intention of imposing a "particular Government on Mexico; all she desired was a Government chosen by the Mexicans, which would make itself respected and would scrupulously fulfil engagements taken with foreign Powers."15 Mon saw Thouvenel immediately after this and was assured by him that he had told Russell that England's fear of Spain's religious intolerance was a "puérilité". The English Ministers, however, were not to be convinced, and their concern about Spain's intentions was to be raised again between Russell and the United States Minister, in discussions which finally determined England's position in relation to Mexico.

Because of O'Donnell's denial that orders had been sent to employ Spanish forces in Mexico Russell told Cowley there was "time for deliberation and concert."16 But he was not to be allowed that time by the Spanish who were determined to act promptly. He had sent a telegram to Crampton to ensure Spain postponed any action while France and England conferred, but Crampton replied that the Spanish government would not agree to defer action beyond the beginning of November. O' Donnell had said "he would be unable to justify any delay before the Cortes and country" but he hoped enough time would still be available for the three governments to agree on action "for the immediate vindication of their respective rights." He had then added that Spain would be ready at some stage to discuss with England and France measures "for placing the Government of Mexico in a position to fulfil its international obligations for the future."17 It can be seen that Spain was determined that some change had to be effected in the Mexican administration, and there was to be agreement from France and England.

Russell in the meantime had responded to comments by Thouvenel regarding what was to be done on their arrival in Mexico. Thouvenel had suggested that they should come to "an early understanding" on "the measures of coercion to which ... the two Governments might have recourse", and that "the two Governments should carry their common understanding still further, and devise means for promoting the political

\footnotetext{
${ }^{15}$ Cowley to Russell, 17 September 1861. State Papers Vol. 52, pp. 322-323.

16Russell to Cowley, 23 September 1861. Parliamentary Papers Part 1, p. 57.

${ }^{17}$ Crampton to Russell (Telegram), 24 September 1861. PRO: FO 72/1010.
} 
reorganization of Mexico", but that the governments of Spain and the United States should be "invited to concur in the course to be taken by the two Powers". Russell agreed with the latter suggestion and advised Cowley to tell Thouvenel his government was ready to discuss what measures could be taken, although "it is evident that much must depend on the actual state of affairs at the time when our forces may be ready to act on the shores of Mexico."18

Thouvenel was pleased to see the two governments were basically in agreement and he decided to broach again the idea of changing the form of government in Mexico. He wrote a letter to Flahault noted "not to be given officially to Russell", in which he said he knew it would be premature in the realm of diplomacy to raise the question of the establishment of a monarchy in Mexico, as England might accuse France of conspiring to hatch a Catholic, monarchical plot with Spain. However, given the proven incapacity of Hispano-Americans to prosper under a republican regime most could see that the monarchical form was more likely to work there, so Flahault should, at an appropriate time, try to lead Russell to recognise that a change in the institutions of Mexico was surely the only help for Mexico. Mexicans would no doubt ask for this themselves if they felt they were being supported by others. He then suggested that as Austria had enough Archdukes it could probably give one to Mexico, adding that if this eventuated it might even help resolve the Italian question. ${ }^{19}$ It is interesting to speculate on the delicacy with which Thouvenel wanted this idea brought forward, as the suitability of a monarchy for Mexico had already been discussed openly between Cowley and Thouvenel, Mon and Cowley, and in the Spanish press early in September. He may, though, have anticipated antagonism to the idea of an Austrian Prince because of concem that France might use this to persuade Austria to cede Venetia to Italy, or he may have seen, as Russell did, that such an issue could not be resolved until after they had actually arrived in Mexico and assessed the situation.

\footnotetext{
${ }^{18}$ Russell to Cowley, 23 September 1861. Parliameneary Papers Part 1, p. 57.

${ }^{19}$ Thouvenel to Flahault, 26 September 1861. Quoted by L. Thouvenel, Le Secret de l'Empereur: Correspondance Confidentielle et inédite Echangé entre M Thouvenel, le Duc de Gramont et le Général Conte de Flahault 1860-1863, 2 Vols., (Paris, 1889), Vol. 2, pp. 175-176.
} 
Thouvenel was not to receive the response he might have anticipated to this proposal, however. In view of Russell's apparent agreement on the need to see a better government established in Mexico, Thouvenel was surprised to hear him suddenly speaking out strongly against interfering in the internal affairs of Mexico. What brought about this determined opposition was a discussion between Russell and the American Minister, Adams, about proposed loans to Mexico by the United States to cover the interest on its debts to Europe. Russell initially had been made aware of this proposal by Lord Lyons, his Minister in Washington, who had advised that Seward, the Foreign Minister, had said:

that if the Convention should be ratified by the United States' Senate, Great Britain and France should engage not to make any demand upon Mexico for the interest, except upon its failing to be punctually paid by the United States.

The inducement to the United States to take upon themselves the payment appeared to be the extreme importance to them of the independence of Mexico. ${ }^{20}$

Cowley mentioned the proposal to Thouvenel who commented that it "might not be possible ... to prevent the United States offering money to Mexico, or to prevent Mexico receiving money from the United States, but neither England nor France ought in any way to recognize the transaction." 21

Where Russell may earlier have been prepared to discuss options related to the political situation in Mexico, his meeting with Adams, crystallised his concerns about interference in that country. He summarised the American position in a letter to Cowley:

a direct intervention with a view to organize a new Government in Mexico, and especially the active participation of Spain in such an enterprise, would excite strong feelings in the United States. It would be considered as that kind of direct interference in the internal affairs of America to which the United States had always been opposed. In fact, there was a sort of understanding that so long as European Powers did not interfere in America, the United States might abstain from European alliances; but if a combination of Powers were to organize a Government in Mexico, the United States would feel themselves compelled to choose their allies in Europe, and take their part in the wars and Treaties of Europe. ${ }^{22}$

\footnotetext{
${ }^{20}$ Lyons to Russell, 10 September 1861 (r. 23 September). Parliamentary Papers Part 1, p. 56.

${ }^{21}$ Cowley to Russell, 24 September 1861. Ibid., p. 59.

${ }^{22}$ Russell to Cowley, 27 September 1861. PRO: FO 27/1380.
} 
This could only be considered as a thinly veiled threat, to which Russell acquiesced, although he did insist that the receipt of payment for outstanding debts would not resolve the problem of protection of "the persons and property of British subjects", or the fulfilment of Mexico's obligations. But he agreed with Adams that the factions in Mexico were too hostile to each other to be reconciled "by a small force of Europeans in the name of order and moderation", and he shared the concern of the United States about the reaction in the Americas to any action taken there by Spain. However, he thought a joint venture with Spain, which excluded interference in the internal affairs of Mexico, would be more acceptable than allowing Spain to go alone "and afterwards opposing the results of her operations." Although O'Donnell had said Spain had no aspirations of reconquest in the Indies, to safeguard against this eventuality Russell suggested to Cowley the following clauses on which a combined operation should be founded:

1. The combined Powers of France, Great Britain, Spain, and the United States, feel themselves compelled, by the lawless and flagitous conduct of the authorities of Mexico, to seek from those authorities protection for the persons and property of their subjects and a fulfilment of the obligations contracted by the Republic of Mexico towards their Governments.

2. The said combined Powers hereby declare that they do not seek any augmentation of territory, or any special advantage, and that they will not endeavour to interfere in the internal affairs of Mexico or with the free choice of its form of government by its people.

Cowley was advised to show this despatch to Thouvenel, and a similar one was written to Crampton, emphasising the futility of interfering by force in Mexican internal affairs and suggesting that the Mexicans alone could "put an end to the anarchy and violence which have torn Mexico to pieces during these last years."23 Just how they might achieve this given their singular lack of success in the previous forty years Russell did not suggest.

Without considering the impact of the United States' position on Russell and Palmerston, Roeder thought England's approach to the Mexican question myopic to say the least, and it is difficult to argue with his viewpoint. He remarked:

${ }^{23}$ Russell to Crampton, 27 September 1861. State Papers Vol. 52, p. 332. 
English interests in Mexico being purely commercial, their primary object was to isolate economic sanctions and prevent them from breeding political complications. Obviously this was impossible. Financial intervention was, ipso facto, political intervention: occupation of the seaports and control of the customs were calculated to throttle the government, and what was to follow its collapse? That question could only be ignored by the blind or the British, but they were old hands at evasion, and they met the question by blinking it. ${ }^{24}$

It has been seen already that Russell's and Palmerston's responses to suggestions from France and Spain, that a new administration was needed in Mexico, were vague and evasive, although they gave the appearance of being in agreement with them. As Roeder pointed out it was futile to just occupy the Customs Ports, but the English Ministers were to become even more firm in their determination not to extend their involvement beyond obtaining satisfaction for their claims. It would seem, though, that the position adopted by the United States was influential in cementing the English attitude.

After his talks with Adams, Russell pointed out to Cowley the difficulties of any foreign army being able to exert authority over the Mexican factions which were scattered over a vast territory. Her Majesty's Government, he said, was "on principle" opposed to "interference in the internal affairs of an independent nation," but it remained "to be considered" whether Mexico might form "an exception to the general rule." $\mathrm{He}$ mentioned, however, the "universal alarm" that would be raised in North America at the idea of a European interference in an American Republic. Further, "it would be ... unwise to provoke the ill feeling of North America, unless some paramount object were in prospect, and tolerably sure of attainment."25 Wyke's letter of 27 August, received on 29 September, in which he said coercive measures by the combined Powers would encourage the Moderate Party to form a government did not seem to carry much weight with Russell. ${ }^{26}$ He told Cowley, though, that the Spanish government believed the successful enforcement of their just demands would effect this result, and Russell added that if a change of government was

\footnotetext{
${ }^{24}$ Ralph Roeder, Juarez and His Mexico, pp. 328-329.

25 Russell to Cowley, 30 September 1861. PRO: FO 27/1380.

${ }^{26}$ Wyke to Russell, 27 August 1861 (r. 29 September), State Papers Vol.52, pp.365-366.
} 
the indirect effect of naval and military operations, Her Majesty's

Government would cordially rejoice; but they think this effect is more likely to follow a conduct studiously observant of the respect due to an independent nation, than to be the result of an attempt to improve by foreign force the domestic institutions of Mexico. 27

This hardening of Russell's views seriously affected negotiations for the Convention, but they were complicated further by various opinions that a Moderate Party was waiting to come forward as soon as the allies arrived. Both Saligny and Wyke, as well as correspondents in Mexico, gave credence to the existence of a party awaiting foreign support to form a new government, and while the French and Spanish governments were convinced, the British government did not appear to be influenced by such claims. On the other hand, perhaps it was, and therefore thought change would be effected easily with little or no support from the allies, which might explain Russell's insistence on not using force. A note written by Almonte, the former Mexican representative in Paris, in September 1861 also spoke of the ease with which the allies could convince the Government in Mexico City to grant an amnesty to all political prisoners and to convoke a congress to reconstitute the nation. The government organised through such a process, he said, would have the moral support of the three European nations. "Voilà tout ce qu'il y aurait à faire pour rétablir l'ordre à Mexico et pour assurer l'existence d'un bon gouvernement dans cette malheureuse République."28

The confidence with which such statements were made undoubtedly had an impact on the French government, and Thouvenel told Cowley that though he had no proposal of influencing by armed force the internal affairs of Mexico, he felt that the "welldisposed part of the Mexican people" should be supported by the Powers if they were encouraged by the allied presence to substitute a new authority in Mexico. Cowley, however, foresaw possible conflict in what each of the three Powers might feel best for Mexico and his suspicions were aroused about the French and Spanish intentions. ${ }^{29}$ In a private letter to Russell, Cowley said he was convinced the French would try "to

\footnotetext{
27Russell to Cowley, 30 September 1861. PRO: FO 27/1380.

${ }^{28}$ Note by Almonte (dated September 1861 in Thouvenel's hand). AMAE: CP Mexique, Vol. 55.

${ }^{29}$ Cowley to Russell, 2 October 1861. PRO: FO $27 / 1397$.
} 
establish a monarchical form of Government in Mexico, and of course Spain will be quite ready to assist." Thouvenel, he said, had suggested "that an Austrian Prince might be placed on the throne, and that might facilitate an arrangement respecting Venetia! a sop to us no doubt!"'[sic]. ${ }^{30}$

The talks between France and England seemed to have reached a stalemate so Napoleon saw the time had come to play an active role and state clearly his position regarding Mexico. He believed that for Europe's sake, and for Mexico's, it was essential that the three Powers be prepared to support whoever appeared capable of forming a stable government in Mexico, and his views were outlined in a lengthy letter to Flahault early in October. This letter has been called the "pièce justificatif" for Napoleon's intentions, "an attempt to 'come clean' at the last moment", 31 but it will be seen that it is a very open statement of ideas and motivations and not at variance with any previously, or later, stated aim. He suggested that the obvious aim of a combined intervention should be to obtain redress for their complaints, but he added; "il faut prévoir ce qui peut arriver et ne pas bénévolement se lier les mains pour empêcher une solution qui serait dans l'intérêt de tous."

One could argue, as has been done, that this was an attempt to leave himself free to impose a monarchy on Mexico. If this were so, why would he insist he would only go to Mexico if England and Spain agreed to go too, and suggest the United States be involved? Could it be that he intended manufacturing a situation whereby France would be left alone in Mexico to impose a monarchy headed by Maximilian? Such accusations have been made, yet how could he possibly guarantee that this would happen, and why go to the trouble of negotiating an entente he intended to break soon afterwards? It is more reasonable to assume that Napoleon believed Spain and England were as committed as he was to seeing a stable and enduring government established in Mexico, and this seemed to be evident in their discussions so far. All three governments had been assured that there was a party of men who would be capable of instituting a new government if

\footnotetext{
${ }^{30}$ Cowley to Russell (private), 2 October 1861. PRO: PRO 30/22/56, Russell Papers.

${ }^{31}$ W.H.C. Smith, Napoleon III (London, 1972), p. 177.
} 
given support, and all Thouvenel's and Napoleon's arguments about the content of the Convention were with this in mind. What, in effect, could possibly be achieved if all the allies sought was compensation and redress for the outrages committed against their nationals? Without the establishment of a sound government to ensure that the same difficulties with Mexico did not continue, what was the point in going to Mexico? Nothing in its Republican history could instil any confidence in the three Governments that such a stable government could emerge of its own accord, and maintain itself for a long period of time without outside support. Therefore Napoleon's arguments about allowing themselves the latitude to take advantage of events after arrival in Mexico seem plausible.

When discussing the idea of a monarchy Napoleon told Flahault that after being asked to name a possible candidate for the throne, the initiative had been taken from his own hands by the committee of Mexicans in Europe "qui prennent naturellement les choses plus vivement que moi et qui sont impatients de voir les événements se précipiter" and who had already gone to Vienna to approach the Austrian Government. Gutierrez de Estrada had in fact spoken with Prince Richard de Metternich, the Austrian Minister in Paris, of the idea of an Austrian Prince going to Mexico as early as July 1861.32 It would seem he could not contain his impatience once France, England and Spain had agreed to go to Mexico, despite the lukewarm reception he had received from Metternich in July. Although Napoleon was obviously in favour of Maximilian, I do not believe he was ready at this stage to approach Maximilian or the Austrian Government. It is much more likely that he would have waited to see what eventuated after the expedition arrived in Mexico before taking such a step, but though the Mexican committee took the initiative Napoleon did not condemn them but accepted their act as a fait accompli and decided to work with it. This is not to say he was determined to see Maximilian on the throne of Mexico. On the contrary he was determined to act according to the desire of the Austrian

\footnotetext{
${ }^{32}$ Henry Salomon, "Le Prince Richard de Metternich et sa Correspondance pendant son Ambassade à Paris", La Revue de Paris, No. 31, Vol. 1, 1924, pp. 520-521.
} 
Cabinet - that the wishes of the Mexican people had to be freely and loyally expressed in favour of Maximilian's nomination - or an alternative government would be accepted.

What is significant about this letter is Napoleon's expressed concern for civilisation as a whole, and his ability to look at this question in the context of a world view rather than as a regional issue, or as an isolated incident. He concluded the letter by declaring his only aim was to see French interests safeguarded for the future by a strong organisation in Mexico, and that helping a nation become prosperous was really working for the prosperity of everyone. He summarised his feelings about the Mexican campaign in his final paragraph:

En résume, je ne demande pas mieux que de signer avec l'Angleterre et l'Espagne une convention où le but ostensible de notre intervention sera le redressement de nos griefs, mais il me serait impossible, sans manquer à la bonne foi et connaissant l'état des choses, de m'engager à ne pas appuyer, moralement au moins, un changement que j'appelle de tous mes vœux, parcequ'il est dans l'intérêt de la civilisation tout entière. ${ }^{33}$

Napoleon was looking beyond just the settlement of the problems with and within Mexico, for he saw Mexico as part of a much larger picture. This can be understood when the Mexican campaign is seen in the context of his proposals for European Congresses - particularly that of 1863 - and of a close study of his Des idées napoléoniennes, both of which will be discussed below in Chapters Seven and Eight. In October 1861, however, was Napoleon trying to justify what he was intending to do regardless, or was he trying to persuade his English and Spanish counterparts to take a different view of the world as a whole? My evidence suggests that the latter course was far more probable than the former, and that despite his entreaties, England was determined to maintain a policy of non-intervention and Spain was to continue its contradictory behaviour as it responded to pressure from England and from Spanish public opinion.

Napoleon's letter did not resolve the difficulties between England and France, although at first it appeared to have done so. After seeing the letter Palmerston agreed

\footnotetext{
${ }^{33}$ Napoleon to Flahault, 9 October 1861. AMAE: CP Angleterre, Vol. 720.
} 
entirely that a monarchy was probably the best and most stable form of government for Mexico, and that Maximilian would be a good candidate, but he "doubted the possibility of any such arrangement." He told Russell that he had been approached ten or fifteen years earlier by Mexicans proposing a monarchy, but when he asked them "their views of practicability it came out that they required a Prince of a reigning European family, many millions sterling and 20,000 European troops to give any chance of success."34 It would have needed little more than this information to ensure that the pursuit of such an idea was carried no further in England. Flahault had already spoken of the influence of public opinion and of political colleagues on the decisions of English Ministers, and it is highly unlikely that the prospect of spending millions of pounds on Mexico and sending thousands of troops there would engender support in either of those arenas. Russell did remark to Cowley, however, that "moral influence is not excluded by the terms of the Convention."35 But then none of the three Governments ever really defined just what was meant by "moral influence" nor what constituted "force".

The following two weeks were spent in negotiations regarding the wording of the Convention, and France was to find that England's official policy was at odds with the messages that Russell and Palmerston were giving them verbally. Flahault tried to convince them to withdraw the clauses from their proposal that said the parties agreed not to use their forces to overthrow the existing government nor to establish a new one, and that they did not wish to interfere in the internal affairs of Mexico. Thouvenel's main concern was that the insertion of these clauses might discourage Mexicans from coming forward on the allies' arrival for fear of lack of support. Both Palmerston and Russell, however, were convinced that Mexico was in such a state of dissolution that they saw little prospect of the allies' arrival encouraging a party more worthwhile than any that had formed previous governments, which seems to contradict their earlier position that the Mexicans were the only ones who could bring an end to the years of anarchy. Flahault remarked that overall he had found them both much better disposed towards the

\footnotetext{
${ }^{34}$ Note, Palmerston to Russell, 15 October 1861. PRO: PRO 30/22/56, Russell Papers

${ }^{35}$ Russell to Cowley, 12 October 1861. PRO: FO 27/1380.
} 
Emperor's ideas than he had expected but, "ils sont convenus, l'un et l'autre, qu'il valait mieux ne pas aborder les questions au conseil qui s'est tenu aujourd'hui."36 If they were not to be discussed in the Cabinet meeting, however, it is obvious there was little chance of any change being made to the proposed clauses.

Thouvenel, though, pressed his argument with Cowley, saying that it was wrong to include a clause stating what they would not do when it was in the interests of them all to take advantage of what happened after their arrival if it was to lead to a better government. The only chance for Mexico to resist a take-over by either the United or Confederate States was if it had a strong government supported by Europe. While openly favouring a monarchy, Thouvenel stressed that ultimately the choice of the Mexicans would be respected. Cowley continued, however, to fuel the accusations that were to be made against Napoleon III that he had just been waiting for the opportunity to impose a monarchy on Mexico. After discussing Napoleon's letter to Flahault with Thouvenel, he wrote to Russell:

More than once His Majesty spoke to me on the subject during the first year of my residence in this country [1852] and has frequently alluded to it since and has always been an advocate for the introduction of a monarchical system, as the only one which would save the country from ruin. ${ }^{37}$

Although a lot of emphasis has been placed on this comment by Cowley, it does not prove that Napoleon was obsessed with the idea of a monarchy in Mexico. The problems in Mexico were discussed in Europe many times during the 1850 s and, as has already been shown, England had also agreed with the suggestions that a monarchical system was the most suitable for Mexico.

Thouvenel's argument, which was supported by Collantes, was that insisting they did not wish to intervene in the internal affairs of Mexico was in fact giving moral support to the existing order of things that they had so much to complain about. Acting on this premise Flahault suggested to Russell combining the two clauses mentioned

\footnotetext{
${ }^{36}$ Flahault to Thouvenel (Personal), 16 October 1861. AMAE: Papiers d'agents-archives privées (PA-AP) 233 Thouvenel.

${ }^{37}$ Cowley to Russell, 16 October 1861. PRO: FO 27/1397.
} 
above and removing such phrases as: "and specifically shall not be employed for the purpose of interfering with the internal Government of the Republic" in the first clause, as well as the words: "in the internal affairs of Mexico" in the second clause. Flahault thought that with these changes the Convention would still indicate that the right of the Mexicans to conserve or change their government would be respected. ${ }^{38}$

Flahault found Russell reasonably agreeable to his suggestions but Russell said he would reserve his final decision till he had read Thouvenel's revised version of the clauses. In a private letter Flahault told Thouvenel that in preparing the ground for him with Palmerston and Russell he had been surprised at their agreement with the ideas of the Emperor. At the same time he knew the possibility of the institution of a monarchy would not be popular in the English parliament. With this in mind he suggested Thouvenel should be careful in his drafting of the clauses not to deliver "la pilule trop amère", because if either Russell or Palmerston felt their political existence might be compromised by agreeing too far with France, they would be far more difficult to deal with than if they enjoyed complete freedom of action. ${ }^{39}$ Thouvenel replied with the comment that his counter proposal bound the contracting parties not to act with any aim other than that which had led to their agreement to take action, and respected the sovereignty and independence of Mexico while showing that they were not indifferent to the restoration of a strong and lasting political regime in Mexico. 40

Spain, while agreeing with France's arguments, was, paradoxically, prepared to accept the original clauses if France and Spain could not make their objections prevail. Collantes felt that England was in fact paralysing in advance the very measures which they had proposed to adopt, and he understood, like Thouvenel, that it would be "illogical and impolitic to discourage in advance the men of order, who are in the majority in Mexico", but who would only be strong enough to dominate "the unpleasant passions

\footnotetext{
${ }^{38}$ Flahault to Thouvenel. Report of conversation with Russell, 19 October 1861. AMAE: CP Angleterre, Vol. 720.

${ }^{39}$ Flahault to Thouvenel (Private), 19 October 1861. AMAE: PA-AP 233 Thouvenel.

${ }^{40}$ Thouvenel to Flahault, 21 October 861 . AMAE: CP Angletere, Vol. 720.
} 
of the minority" with the moral support of the combined forces of the three Powers. ${ }^{41}$ Crampton reported to Russell that Collantes had asked for the inclusion of a clause stating they intended "to exercise a moral influence on the affairs of Mexico" to effect a suspension of hostilities between contending parties with a view to constituting a new, stable government. While Crampton said that such influence was not excluded by England's proposal, Collantes felt the inclusion of such a clause would demonstrate to the world "the desire of the Three Powers to ameliorate a state of things which seemed every day to become more at variance with the interests of civilization and humanity." 42 But again, he was prepared to forego the inclusion of such a reference if England would not change its opinion.

Thouvenel also objected to clauses which clearly specified what the three parties would do on their arrival in Mexico, such as to blockade the ports and to refrain from going to the interior of the country. This latter point Thouvenel saw as particularly important because all three countries had nationals needing protection in all parts of the country. These kinds of stipulations, he believed, would be more appropriately contained in the orders of the commanders, and those orders should provide enough latitude for them to respond to the situation as it was on their arrival. He added that he stood by his counter-proposal regarding intervention, saying that it went without saying that they were only seeking redress for wrongs and that France excluded, with England, any employment of force to impose any form of government on Mexico. At the same time they could not undertake in advance not to give moral support to any attempt by Mexicans to reorganise their administration. ${ }^{43}$

Finally, the Emperor agreed after discussion, to suppress the words "partout ou elle se trouverait menacée", relating to foreign nationals, from the French counter proposal, hoping that England would agree that their commanders could decide to take necessary action, within the limits of their resources, to protect their nationals. ${ }^{44}$ Flahault

\footnotetext{
${ }^{41}$ Barrot to Thouvenel, 21 October 1861. AMAE: CP Espagne, Vol. 859.

${ }^{42}$ Crampton to Russell, 20 October 1861. PRO: FO 72/1010.

${ }^{43}$ Thouvenel to Flahault, 25 October 1861. AMAE: CP Angleterre, Vol. 720.

${ }^{44}$ Thouvenel to Flahault, 28 October 1861. AMAE: CP Angleterre, Vol. 720.
} 
verified Russell's agreement to this provision and heard that Russell's only objection had been to a prolonged occupation, not to the possible need to go to the interior of the country. With this clarified, in the presence of Isturiz, the Spanish Minister, Flahault declared he was ready to sign the Convention on behalf of the French Government. ${ }^{45}$ Russell was perhaps more agreeable at this point because he did not anticipate the need for a prolonged occupation in the light of Wyke's latest despatch, which had arrived on 30 October. Wyke had advised that the Executive had lost any real authority in Mexico, and that with the moral support of the allied occupation the "moderate and respectable party" would probably be strong enough to overturn the administration, form a government and treat with the three governments. ${ }^{46}$

Despite apparent agreement on the final content of the Convention, the signing of it on 31 October was by no means an indication of perfect accord among the three Powers, and the path from then on was beset by difficulties caused by varying interpretations of the document they had signed. From the written and unwritten agreements among the three Governments emerged a series of accusations, "malentendues", and perhaps disasters, which cannot be laid solely at the feet of Napoleon III and his emissaries. Spain's precipitate arrival on the shores of Mexico was to prompt Napoleon to send more troops to equalise the number of French and Spanish troops, and this in turn excited suspicion of his intentions in England and Spain. When the suggestion of Maximilian for the position of monarch in Mexico became public in January 1862, both the English and Spanish Ministers were to deny any prior knowledge of his nomination, and Napoleon was accused of intending all along to impose a monarchy. But the denials of the English government cannot be supported, and it will be seen in the following chapter that the Spanish and English were well aware of the suggestion of Maximilian. Their determination to accuse Napoleon of subterfuge, and to protect their own positions before their parliaments, was to have a decisive impact on Napoleon, and on the course of the campaign.

\footnotetext{
45Flahault to Thouvenel (Private), 1 November 1861. AMAE: PA-AP 233 Thouvenel, Vol. 8.

${ }^{46}$ Wyke to Russell, 29 September 1861 (r. 30 October), Parliamentary Papers Part 1, p. 101.
} 


\section{Chapter $\$$}

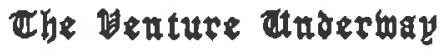

The conclusion of the Tri-Partite Convention was not the end, but really just the beginning of discussions to reach agreement on the action to be taken in Mexico. Each government had, however, managed to achieve some compromise on the part of the other governments, which laid the groundwork for the ensuing negotiations and preparations. France and Spain remained convinced of the inadequacy of limiting their actions as the English proposed, and France set about obtaining England's agreement, or at least acquiescence, to moving their troops inland. Although Napoleon was accused of being underhand in relation to his intentions in Mexico, it will be seen that, on the contrary, he was open with the other governments about his ideas and plans, although he was, naturally, trying to get them to agree with his perspective.

In the previous chapter the futility of limiting action to the coast was discussed, and this argument was supported by contemporary writers. Charles de Mazade wrote on the impossibility of the Powers having any effect on the situation in Mexico if their efforts were limited to the occupation of the coastal customs ports. He remarked that the "deplorable states" of Mexico were accustomed to acceding to force and as soon as the foreign forces departed they just resumed their demands and their violence against foreign nationals. ${ }^{1}$ An English observer later expressed similar views on the futility of limiting action to the control of the ports, but he was more forceful in his criticism, particularly of the English Government, when he said, "if the objects of the expedition were to be limited only to the seizure and occupation of the ports, a more ineffective and preposterous measure for effecting the expressed purposes of the convention could scarcely be conceived". ${ }^{2}$ It was precisely with these realisations in mind that Thouvenel

\footnotetext{
${ }^{1}$ Charles de Mazade, "L’Expédition du Mexique", R.D.M., Vol. 37, 1 February 1862. p. 768. De Mazade was a political observer who wrote numerous articles in journals such as La Presse and Revue des Deux Mondes on aspects of French foreign policy and international politics. He wrote on Mexico, the political events in Spain, the Italian question and on the Polish situation and its importance to the balance of power in Europe.

2“The Empire of Mexico" Quarterly Review Vol. 115, April 1864, pp. 348-381.
} 
advised Barrot, his Minister in Madrid, to discuss confidentially with O'Donnell and Collantes the suggestion that instructions to the French and Spanish commanders authorise them to march to Mexico City, if the circumstances seemed favourable to them. In this confidential telegraphic despatch Thouvenel said that a preliminary agreement in this respect would be impossible with England because of "the situation of the Cabinet before the parliament". He felt, though, that if France and Spain together gave the broadest possible interpretation to the article providing for the necessity to protect resident foreigners, it was highly likely that their commanders would not encounter any opposition on the part of the English Admiral. ${ }^{3}$ O'Donnell immediately agreed and said he would give "very elastic and discretional instructions" to the commander of the Spanish forces, and that he would give him a personal letter authorising him to act if necessary in the manner outlined by Thouvenel. ${ }^{4}$

Having obtained Spain's agreement, Napoleon and Thouvenel were determined to be as open as possible with England, and Thouvenel wrote to Flahault, saying:

il était plus franc, en tout cas, de ne pas lui laisser ignorer nos intentions, si éventuelles qu'elles soient. Le Times, d'ailleurs, a publié un article reproduit aujourd'hui par les Débats et qui prévoit, sans nulle réticence, la nécessité d'aller dicter les conditions d'un arrangement dans la capitale même du Mexique. ${ }^{5}$

It is interesting to notice how often there were articles printed in The Times which supported what the French were doing, or planning to do in Mexico. It seems to make the ambiguous behaviour of Russell and Palmerston even more questionable. However, Napoleon and Thouvenel pursued their open policy and included in Flahault's letter a copy of the instructions that were to be given to the commander of the French forces, and said they were to be shown to Russell. There was nothing in these instructions, other than the perceived necessity to march inland, to which England could object, or with which it had not agreed in correspondence with the other governments or with Wyke, although Thouvenel's confidential instructions broached the nomination of Maximilian if

\footnotetext{
${ }^{3}$ Thouvenel to Barrot, Telegram (confidential), 5 November 1861. AMAE: CP Mexique Vol. 859.

${ }^{4}$ Barrot to Thouvenel, 6 November 1861 . Ibid.

${ }^{5}$ Thouvenel to Flahault, 11 November 1861. L Thouvenel, Le Secret de l'Empereur Vol. 2, pp. 185-186.
} 
the Mexicans desired a monarchy, while those shown to Russell suggested attempts by the Mexicans to change their administration should not be discouraged.

Prior to drafting the instructions Thouvenel had heard that the Mexicans intended to withdraw inland so they would not be available on the coast to negotiate with the allies. It was therefore likely, he told Admiral Jurien de la Gravière, who was to be the French commander, that their demands would not be met by occupation of the ports and it would be useless to remain there indefinitely if there was no prospect of putting pressure on the government from that position. In the interests of their dignity, and in consideration of the climatic conditions on the coast it was important that a prompt and decisive result was obtained. For these reasons, and in anticipation of the need to protect foreigners in the interior of the country, Jurien was told the government anticipated the forces having to proceed inland and he gave him the liberty to take this action if necessary.

The issue of a possible change of government was then mentioned in terms that indicated there was no pre-determined idea on what might eventuate in this respect. Jurien was advised not to discourage any initiatives taken by any persons or party to try and form a more stable government and to give his moral support if he thought they had any chance of success. Thouvenel raised the question of whether or not such a party existed with the near certainty of success, and advised Jurien that it would be up to him to determine this on his arrival through his own investigations and discussions with Saligny. But he was not told to proceed, come what may, to support such a party or to ensure a change of government. It was instead suggested that a proclamation should be made prior to a march to the capital to reassure the nation that they had no plans of conquest, or of interfering in their freedom to choose the government, and form of government they wanted. Thouvenel's instructions were in fact rather circumspect. He wrote:

Just as it would be generous and useful to aid a nation to leave the abyss, just so it would be rash in itself and contrary to our interests to risk an adventure. Therefore it is to inspire the honest and peaceable portion of the Mexican people the courage to make its voice known that our efforts must be held out; if the nation remains inert, if it doesn't realize that we offer it an unexpected staff of safety, if it doesn't give a practical sense and morality to 
our protection, it is evident that there is nothing we can do but remain within the terms of the Convention of 31 October and only occupy ourselves with the specific interests for which it was concluded. Things would be incomplete, however, unless, once the forts are occupied, an expedition were directed into the interior and really as far as Mexico City. ${ }^{6}$

Although Russell at first could see great problems with a march to Mexico City, Flahault was able to convince him that they would be laying themselves open to the ridicule of the whole world if after seizing the ports they were still powerless to obtain reparation. It seemed, though, that Russell's main objection was to the prospect of the Spaniards leading the march because of their greater numbers, and that the political group encouraged by them would be the most retrograde and intolerant in religious matters. Russell was also concerned at Spain's desire to have the Spanish general in overall command but was reasonably happy with Flahault's suggestion that if the Spanish troops did march alone to Mexico City they should be accompanied by commissioners from the other two nations. Flahault admitted he had expected Russell to be more "recalcitrant" regarding going to Mexico City, and although Palmerston had not welcomed the idea with "great pleasure" he had not shown complete opposition to the idea either. In summary, Flahault felt that Russell's and Palmerston's fears were related more to Spain than to France, and the reputation enjoyed in England by Admiral Jurien de la Gravière was enough to inspire confidence there. ${ }^{7}$

In his instructions to Wyke, Russell admitted that originally he had not foreseen the possibility of the Mexicans withdrawing inland and refusing "to enter into any agreement or negotiation whatever", but now appreciated it might be necessary for the allies to pursue them there. ${ }^{8}$ In fact Russell had received a despatch from Wyke on 30 October advising him precisely of that plan by the Mexicans. Wyke had written that they would "withdraw the Custom houses further inland, with a view of levying duties on all goods proceeding from the coasts to the capital", but he suggested their lack of organisational

\footnotetext{
${ }^{6}$ Thouvenel to Jurien (confidential), 11 November 1861. Quoted by C.H. Bock, Prelude to Tragedy, pp. 522523.

${ }^{7}$ Flahault to Thouvenel (Private), 13 November 1861. AMAE: PA-AP 233 Thouvenel, Vol. 8.

${ }^{8}$ Russell to Wyke (copy), 15 November 1861 . Archives Nationales (AN): BB ${ }^{4} 1817$ bis.
} 
ability would prevent them being successful. ${ }^{9}$ Russell, however, told him only 700 English marines were being sent who could not be employed to go inland, and he was not to direct them to do so even if the opportunity arose. By the same token he had "nothing to say against this reasoning [of the French] or the measures in contemplation". ${ }^{10}$ In other words, let the French and Spanish go if they like, but England will not be involved, an attitude which did not augur well for a combined expedition.

Perhaps Russell was more influenced in his reasoning by another statement in this same despatch from Wyke which led him to believe they would not encounter too many difficulties in the campaign:

With the moral support given by our occupation to the moderate and respectable party, they will probably be strong enough to turn out the present Administration and form a Government which would be glad to treat with us, and thus re-establish those friendly relations with foreign Powers so necessary to the real welfare of the Republic. ${ }^{11}$

Russell foresaw it might be necessary to blockade a port, or to prevent "the establishment of Mexican custom houses between the coast and the upper country of Mexico", or even to send detachments to various points in the country to protect Europeans, but basically he invested Wyke with the power to make whatever decisions he thought were appropriate in the circumstances as the Government had "entire reliance upon [his] judgement and discretion". In most respects the instructions of the Spanish government resembled those of France and England and provided for the necessity to march inland. Collantes's letter to General Prim placed a lot of emphasis on the need for a new, reliable and strong government to be established in Mexico, while stressing that the allies had agreed not to interfere actively in bringing this change about. However, he said, it was possible that the presence of the allies would inspire the "sensible" men of the republic to constitute such a government and it would be "supremely unjust and cruel to thwart such a patriotic enterprise". As Spain had everywhere brought the principles of civilisation,

\footnotetext{
${ }^{9}$ Wyke to Russell, 29 September 1861 (r. 30 October). Parliamentary Papers Part 1, p. 101.

${ }^{10}$ Russell to Wyke (copy), 15 November 1861 . AN: BB ${ }^{4} 1817$ bis.

${ }^{1}{ }_{\text {Ibid. }}$
} 
they had a duty to help the Mexicans to regain what they had lost, but their influence could only ever be "purely moral", he added. ${ }^{12}$

Preparations began for the departure of the expeditionary forces, and the constitution of the three contingents is a telling reflection of the attitudes of each of the governments. Of special significance is the fact Napoleon had insisted the number of French troops be less than those of Spain, which indicates he was not intending this to be a French venture and that an alliance with Spain and England was at least as important as the mission itself. He prepared to send 2,000 marines and 600 Zouaves, Algerian soldiers, to be commanded by Admiral Jurien de la Gravière, which also implies he did not anticipate a big military campaign or he would have sent more military personnel and a commander from the army. England committed itself to sending only 700 marines, which confirmed its intention to remain on the coast and take limited action. Spain, on the other hand, decided to send 5,000 troops under the command of General Prim, signalling its determination to take decisive action and that it was prepared for war if necessary.

The strange variation in the number and types of troops immediately raises the question of what resistance and difficulties each of the three governments anticipated meeting on their arrival in Mexico. The comments quoted above, however, indicate that the answer to this was very little, and very few. Charles de Mazade observed that having provided for the possibility of going inland the allied forces were to depart singularly unprepared for what they might encounter. They seemed to have had no idea that in an unknown, almost deserted country these soldiers would need means of transport, guaranteed supplies, camping and military equipment. He noted that even the Spanish, who had resources in Havana, were not organised for action, only one battalion having camping gear, and none of the forces had what would be necessary to set up bases inland. He concluded:

${ }^{12}$ Collantes to Prim, 17 November 1861. A.D., Vol. 7, 1862, p.322 
Qu'en pouvait-il résulter? C'est qu'une fois l'expédition partie, les gouvernements n'étaient plus maîtres de rien; on allait se trouver à chaque pas en face de l'imprévu, de l'inconnu. ${ }^{13}$

And he was right, for the lack of physical resources and supplies influenced some of the decisions that were later made in Mexico. The impact of this, however, was to be disputed by the various Plenipotentiaries and commanders as the French campaign got under way.

But already the three governments were "masters of nothing" in Mexico. While they were negotiating and making preparations, Wyke, Saligny and Serrano were making their own decisions that were to upset the plans made by their governments. The first of these was that of Wyke to negotiate with the Juarez government in a manner contradictory both to his own earlier views and to his government's instructions. He had decided not to follow Russell's orders of 21 August which told him to issue an ultimatum to the government to hand over control of the customs houses, or relations with Britain would be suspended. He decided instead to "reason them into the necessity of complying with the demands which ... would soon be urged in such a manner as to compel the government of the Republic to listen to them with attention". ${ }^{14}$ Although he knew his government was concluding an agreement with France and Spain for a combined expedition, Wyke proceeded to negotiate a settlement of the British claims with Zamacona, the Foreign Minister, who said his government would find it difficult to sanction having interventors in the customs ports, or to accept responsibility for the debts of previous governments. In complete contradiction of his claim a few months earlier that this Government was culpable for squandering its resources and should be coerced into paying its debts, Wyke accepted Zamacona's assertion that it was all but impossible for his government to procure resources to comply with the British demands. In answer to this difficulty, Corwin, the United States Ambassador, had come forward recently with the offer of the loan previously mentioned. Wyke told Russell it was impossible for

\footnotetext{
${ }^{13}$ Charles de Mazade, "L'Expédition du Mexique et la Politique Française", R.D.M., Vol. 48, 1 December 1863, pp. 682-683.

${ }^{14}$ Wyke to Russell, 28 October 1861. State Papers Vol. 52, p. 384.
} 
Mexico to pay its debts without such a loan and England should wait for it to be ratified by the American Congress in January.

Wyke's agreement was not to find favour anywhere, however. The Juarez Government refused to ratify it and Wyke was furious, immediately announcing his departure from Mexico City for Vera Cruz. Russell also refused to approve it, although he was pleased at the precision with which Wyke had drawn up the British claims and felt it would make future negotiations easier if France and Spain did something similar. He noted, though, that Wyke had not negotiated any security that the terms of this convention would "be observed any better than former stipulations and engagements", and it was for this reason he disapproved of it. ${ }^{15}$ The actions of Wyke did not serve to improve his relationship with Saligny either, for Saligny began, in a letter to General Serrano, to refer to the "perfidious Albion", in the guise of Wyke trying to negotiate a separate agreement for the English claims. ${ }^{16}$

It would seem that Saligny was concerned that if Wyke's negotiations proved successful, the need for an intervention might be obviated. He was also still smarting from the rejection of his accusation of an attempt on his life, and of other claims he had made against the government, so he wrote to Serrano in Havana that if he was going to take strong action he should do so without further delay. ${ }^{17}$ It is difficult to know if Saligny had any influence on Serrano, but Serrano had already made extensive military preparations in the absence of precise instructions from his government. He wrote to Collantes that from the bases for the Convention he inferred that he was to wait for the other forces before acting, but as he was not told this formally, he felt the departure should not be delayed, firstly because Spain had taken the initiative in this question and could not be seen to arrive in Mexican waters after the others, and secondly, each day of inaction uselessly increased the costs of transport. He was therefore departing on 29

\footnotetext{
15 Russell to Crampton and Cowley, 28 November 1861. Siate Papers Vol. 52, 1861-1862, pp. 388-389.

16 Saligny to Serrano, 24 November 1861, A.D., Vol. 7, 1862, pp. 342-343.

17 Saligny to Serrano, 24 November 1861. Ibid., pp. 342-343. See also comments on these events in Ralph Roeder, Juarez and His Mexico, pp. 386-389
} 
November on the assumption that the other forces would set sail as soon as the Convention was concluded. ${ }^{18}$

It is hard to know what reaction the Spanish government anticipated from the French and English governments to this early departure of the Spanish forces, but there is little doubt that Collantes deliberately delayed sending revised orders to Serrano. He admitted to Mon, on 10 November, that it was highly likely that by "good fortune" Serrano would have left Havana before the arrival of the allied forces. This meant action could be taken without delay by Spain and, in any case, later operations could be agreed among the allied forces. Further, any action taken by the Spanish would be considered as being in the name of all three Powers. 19 This proviso of acting for the others was no doubt meant to absolve him from any underhand intent, but the effect of Spain's action was to alter the approach of the allied representatives on their arrival in Mexico, and arouse suspicion in the other governments.

News of Serrano's departure was sent to Paris by Captain de Challié, head of the French naval station near Mexico. He was most concerned at the probable effects of it, and provided another picture of the situation in Mexico, revealing that he, like Napoleon, saw the fate of Mexico within a broader context. He believed war between Spain and Mexico would be inevitable and Mexico would refuse to give any satisfaction to the Spanish Government. It was also certain that when news arrived of the departure of the Spanish from Havana there would be a popular rising in Mexico against them. In de Challié's view the situation in Mexico was now so "deplorable" there was a pressing need for an intervention. There was no longer a government or a nation, he said, and society was returning to "barbarism", so perhaps for Europe it was no longer just a question of commercial and financial interests to be resolved. Suffering, he believed, had reached the point where the sensible portion of Mexicans wanted a profound change in the Constitution, moral standards and politics of the country. He went on to say:

${ }^{18}$ Serrano to Collantes, 26 November 1861. A.D., Vol 7, 1862, p. 323
${ }^{19}$ Collantes to Mon, 10 November 1861. A.D., Vol. 7, 1862, p. 316 
L'Europe a un véritable intérêt à sauvegarder ce beau Pays: toutes les nations sont dans une certaine mesure, solidaires les unes des autres aujourd'hui: quand la civilisation succombe sur un point du globe, il faut que partout on lui vienne en aide; et la situation parait si grave au Mexique que l'on peut croire à la nécessité de remèdes héröiques. ${ }^{20}$

His ideas could perhaps be interpreted to mean that other nations had a licence to intervene wherever they liked, but his motivation might also be interpreted as more humanitarian than that, as can be seen in his concern at the attitude of the Spanish forces. He felt they were delighted to have the opportunity to act alone in Mexico, and that they believed there were Mexicans who would look to the idea of a monarchical reorganisation under a Spanish Prince to rescue them from "the edge of the abyss". De Challié said he might be wrong, but he believed this idea was prevalent in the army and gave rise to a vision of the renewed grandeur of Spain and the revival of the enthusiasm and devotion of the Mexicans for Spain, a possibility that he himself believed highly doubtful. ${ }^{21}$

The response of the Mexican Government to the arrival of the Spanish was swift, though initially affecting the Mexicans more than the Spanish or other foreign nationals. However, Juarez made certain that there would be no resources in the vicinity of Vera Cruz that would assist the Spanish, and their allies when they arrived, to move inland. A decree was issued forbidding any communication by Mexicans with the enemy forces, on pain of confiscation of their property and of being treated as spies. Anyone who provided them with supplies would be treated similarly, and any cattle, horses or mules found within a radius of eight leagues of the area occupied by the enemy would be declared public property. Juarez followed this decree with the announcement of a complete and general amnesty for all political offences committed since 17 December 1857, no doubt, de Challié said, hoping by this to rally around him "the liberals, reactionaries, clericals, independents, highwaymen and tutti quanti."22 It can be seen, though, that Juarez was not intending to succumb easily to pressure from the allies.

${ }^{20}$ Challié to Minister of Marine and Colonies, 30 November 1861. AN: BB 499 .

${ }^{21}$ Challié to Minister of Marine and Colonies, 12-20 December 1861. Ibid.

22 Ibid. 
Wyke, too, was concerned by the precipitate move of the Spanish. This contributed to a change in his stance regarding determined action against the Mexican government, and led in turn to the decision of the Plenipotentiaries to negotiate with Juarez instead of demanding retribution, as they had been instructed. He wrote to Russell that the hatred of the Spanish was intense and he feared hostilities between the Mexicans and Spanish would result in a war requiring three times the number of troops being sent. He added:

Everything therefore depends on the manner in which matters are managed here at first: if the intervention is properly received it will prove a blessing to the country; but on the other hand violent measures at first will spoil all, and engage us in an undertaking the difficulties of which can hardly be overrated. The Government as such is nearly powerless for defence but from the nature of the climate and the guerrilla habits of an armed people accustomed to war and strife for the last thirty years, it will be difficult to subdue them by force of arms when their national pride is aroused and they imagine that they are fighting against Spanish ambition to reduce them to their ancient servitude. ${ }^{23}$

This change in the attitude of Wyke was also influenced by the reported reorganisation of the Juarez Government. Juarez at this time was no doubt trying to consolidate his Government in the face of the European intervention, and invited General Manuel Doblado, Governor of the State of Guanaxuato, to join his Ministry as Minister of Foreign Affairs. According to Saligny Doblado then obtained from the Congress and the President almost dictatorial powers, which led Saligny to wonder why he had not decided to take the place of Juarez. Wyke attributed the changes within the Government to the disagreements which arose over the rejection, by the Congress, of his Convention with Zamacona. He told Russell that Doblado had now been endowed with the authority to settle pending questions with the three Powers as he deemed best. Having obtained these he adjourned the Assembly until April next, and now remains unfettered to make the best arrangement he can with us.

He is a man of such talent and influence in the country that the Reactionary Chiefs began to lay down their arms and give in their adhesion on his appointment becoming known, and he is now engaged in forming his Cabinet from the best men he could find, irrespective of their political opinions. 24

\footnotetext{
${ }^{23}$ Wyke to Russell, 29 December 1861 (r. 29 January). PRO: FO 50/354.
}

24 Wyke to Russell, 29 December 1861 (r. 29 January), Ibid. 
Doblado apparently offered to conclude an arrangement with Wyke which would give England guarantees that Mexico's engagements towards them would be fulfilled, but having received news of the joint Convention being concluded, Wyke was unable to take advantage of this "overture".

The allied Commanders in the meantime had met in Havana and were beginning to make their plans based on their instructions, their own preconceptions of the situation and the news that reached them from Mexico. Their first discussions covered the issue of going inland from Vera Cruz, a move now made necessary by the retreat of the Mexicans. Admiral Jurien discussed with General Prim and Commodore Dunlop his intention to march to the interior if necessary as soon as his artillery arrived, and Prim advised he too intended to advance to the interior as soon as he could. ${ }^{25}$ Dunlop said that though his orders forbade such a move, he agreed with them that events could modify his Government's intentions in this regard. ${ }^{26}$ It would seem that everyone except the British Government anticipated, and was prepared, at least in principle, for a move to the interior of the country as soon as the forces landed in Mexico.

The chance of the English being involved in this move, always remote regardless of the urging of Wyke and others, became even more so when the British postal steamer, the Trent, was seized by the United States, and two Confederates, James Mason and John Slidell, who were heading to Europe to represent the Confederate States in London and Paris, were removed from on board. When the United States refused to release the Confederates and return the Trent to British control the prospect of war became distinctly possible. Napoleon immediately joined his protest to that of England in the desire to prevent a conflict, and by so doing gave a further indication that he was intent on cementing his relationship with England rather than breaking it as some have claimed. He had Thouvenel write to Mercier, his Minister in Washington, to protest that by

\footnotetext{
${ }^{25}$ Commodore Dunlop became the British representative with Sir Charles Wyke in place of Admiral Milne who was directed to Bermuda to help resolve the "Trent" affair.

26 Jurien to Minister of Marine, 28 December 1861. AN: BB 799.
} 
international law the only thing that could be seized from another vessel was war contraband. Thouvenel added:

Voulait-on ne voir dans les envoyés que des traîtres, l'arrestation serait encore moins justifiable, car un navire est une portion du territoire de la nation dont il porte le pavillon et par conséquent un souverain étranger ne peut y exercer aucune juridiction. 27

Thouvenel also suggested that as the United States had at other times protested more strongly that other nations at breaches of this law, they should defer to the demands of Great Britain, and release the two prisoners. Apparently President Lincoln, the Congress and the Cabinet were not disposed to make any concessions to England, so Secretary of State Seward hoped that France would help him bring his colleagues to see reason. ${ }^{28}$ When the protest from France arrived and was discussed by the Congress, it was agreed that Mason and Slidell be released, and it was recognised that it was the intervention of France that had helped resolve the conflict. The British Minister in Washington, Lord Lyons, could not speak highly enough of the part played by Mercier in convincing America that France would stick by England in the Trent affair and that there was no intention of leaving England to fight the United States while France made war in Europe. ${ }^{29}$ Even Palmerston, "who could rarely judge an act of Napoleon without suspecting some hidden treachery", was grateful to Napoleon for his intervention. ${ }^{30}$

In the light of this major incident there can be no doubt that the attention of the English Ministers was diverted from Mexico, which would have been unimportant by comparison. Always reticent to take strong action there, the British government would now be even more wary of antagonising the United States by too active an involvement in Mexico. To resolve the Trent affair Admiral Milne was directed to go to Bermuda where his presence was considered "more useful", instead of to Mexico, and reports quickly reached Havana that the English anticipated war with the United States and

\footnotetext{
27 Thouvenel to Mercier, 3 December 1861. Quoted by Émile Ollivier, L'Empire libéral, Vol. 5, p.268.

${ }^{28}$ Lynn M. Case, Edouard Thouvenel et la Diplomatie du Second Empire. Traduction française par Guillaume de Bertier de Sauvigny (Paris, 1976), p. 358.

${ }^{29}$ Lyons to Russell, 23 December 1861, enclosed in a letter from Russell to Cowley, 8 January 1862. PRO: FO 519/199 Cowley Papers.

30Émile Ollivier, L'Empire libéral, Vol. 5, p. 269
} 
"attached no more than a mediocre interest to the Mexican expedition". 31 This view is confirmed by the fact that reinforcements were ordered for Milne on 6 December and that in a letter to Lord Cowley in Paris at the end of December regarding the situation in Mexico, Russell added a postscript saying: "There is no hurry about this Mexican affair."32

It was shortly after this that news reached Europe of the arrival of the Spanish forces in Mexico, and the result of this precipitate action was that the expedition had hardly begun before the three Governments found themselves faced with the unknown, and no longer "master of their resolutions".33 Russell made an observation in this respect to Crampton in Madrid when advising him of the British Government's response to Spain's explanations of their early arrival in Mexico. Its actions, he said, demonstrate that a combined expedition, at a great distance from Europe, is subject to the discretion at all times, to the rashness sometimes, of the separate Commanders and Diplomatic Agents. ... [C]ommanders acting at a distance require to be closely watched, lest they should commit their principals to unwarrantable proceedings. ${ }^{34}$

It also created suspicion as to the motives of Spain, and Napoleon believed the Spanish had some personal plan in hastening the departure of the expedition. He therefore decided to increase the number of French troops to approximately the same as the Spanish. In justifying this increase Thouvenel advised Flahault the government was prepared to accept that the Spanish had not intended to take separate action, but it was evident that their arrival alone had aggravated the "passions" of the Mexicans much more than the simultaneous arrival of the allied forces would have done. Moreover, the withdrawal of the Mexicans from the ports justified the foresight of the government in anticipating the need to go inland, for which purpose they needed to have the appropriate means available. Thouvenel asked Flahault to emphasise to Russell that the Emperor's decision to increase the French contingent did not imply any modification in the

\footnotetext{
31 Jurien to Chasseloup-Laubat, 28 December 1861, AN: BB 499.

${ }^{32}$ Russell to Cowley, 27 December 1861. PRO: FO 519/199 Cowley Papers.

${ }^{33}$ Charles de Mazade, "La Guerre du Mexique", R.D.M., Vol. 40, 1 August 1862, p. 745.

${ }^{34}$ Russsell to Crampton, 19 January 1862. State Papers Vol. 52, 1861-1862, pp. 417-418.
} 
instructions of the French Commander-in-Chief, as will be seen in the orders given to the general in command of this new contingent. ${ }^{35}$ Russell accepted the Emperor's motives but remarked that it was not possible for England to send more troops itself. ${ }^{36}$

Thouvenel also raised with Cowley the idea of the advantage of a change in the form of government in Mexico, based on the argument that France and England had "a real political interest" to prevent Mexico from falling under the influence of the North American States, either united or divided. Therefore, if the proposal of a monarchy headed by Maximilian eventuated, surely the result would be welcomed in London. In reporting his conversation with Cowley to Flahault, Thouvenel added that this argument could not possibly be considered suspect and he hoped that even if the English Ministers could not show themselves to be openly supportive of the idea in the face of parliamentary opposition, France could ask nothing more than that they "apply the doctrine of 'laissez-faire, laissez-passer'." 37 Cowley, however, reported to Russell that he had told Thouvenel he thought the Emperor

was preparing unnecessary difficulties for himself, for that if all I heard was true, the Emperor was quite deceived as to the state of public opinion in Mexico.... Any attempts to interfere with the free choice of the Mexicans themselves would, I was convinced, not succeed in the long run. Thouvenel made a number of protestations that there was no intention to coerce, and this may be so, but there is evidently an intention to advise, and French advice sometimes resembles coercion. ${ }^{38}$

Russell's response showed that Thouvenel was correct in assessing the English Minister's reticence before parliament. He wrote:

This attempt to set up a monarchy in Mexico will never do - let the French have an equal number of men with the Spaniards, but let them keep to the Convention. If they act otherwise we shall not be able to defend our Convention in Parliament. ${ }^{39}$

Palmerston on the other hand told Russell he thought the "monarchy scheme . . would be a great blessing for Mexico and a godsend to all countries having anything to

\footnotetext{
35Thouvenel to Flahault, 17 January 1862. AMAE: CP Angleterre Vol. 721.

${ }^{36}$ Flahault to Thouvenel (Private), 20 January 1862. AMAE: PA-AP 233 Thouvenel, Vol. 8.

37 Thouvenel to Flahault, 17 January 1862. L Thouvenel, Le Secret de L'Empereur, Vol. 2, pp. 225-226.

${ }^{38}$ Cowley to Russell (Private) Copy, 17 January 1862. PRO: FO 519/229, Cowley Papers. Emphasis given.

${ }^{39}$ Russell to Cowley (Private), 18 January 1862. PRO: FO 519/199, Cowley Papers.
} 
do with Mexico". He saw it as a chance to stop the advance of North America and therefore as being an advantage to Europe. His only concern was that England should not take part in the project, but he had no complaint if France and Spain wished to support such a proposition. ${ }^{40} \mathrm{~A}$ few days after this comment an article appeared in The Times supporting the idea of the French army re-establishing a "good government in this unfortunate country". The author presaged a lengthy occupation of Mexico City, but commented that if the result was as happy as that in Syria the world would have cause to be satisfied. In any case, he added, France could count on their acquiescence to their efforts to re-establish tranquillity, and they were not jealous of the preponderance of French forces. He also suggested it might be necessary to occupy the capital for a year or two until a strong government was established, but that would not cause any anxiety on their side of the Channel. ${ }^{41}$ It is difficult to know if this was inspired by Palmerston, but the spirit is in keeping with what Palmerston had said to Russell, and also with earlier comments made about France being occupied elsewhere other than in Europe. Flahault then had a long conversation with Russell in which he felt he had convinced him that by increasing the number of French troops there would be less chance of the Spanish being able to support the "ultra Catholic party", and more chance of liberal and enlightened opinions prevailing, especially if a monarchy were established. Although Russell was not opposed in principle to the idea of Maximilian being proposed for a throne in Mexico, he doubted the chances of its success. He hoped that if such a proposal did eventuate it would only be obtained by the free vote of the Mexicans. ${ }^{42}$

When the subject became more open, however, the reactions of both the English and the Spanish governments were to surprise Napoleon. Although the French had always said the decision must ultimately rest with the Mexicans, the English, particularly Cowley, were still concerned that France might try to impose a monarchy. The instructions of Napoleon to General de Lorencez, who was to take command of the

\footnotetext{
${ }^{40}$ Palmerston to Russell (Private), 19 January 1862. PRO: Russell Papers. Quoted by C.H. Bock, Prelude to Tragedy, pp. 343-344.

${ }^{41}$ Reported in Journal des Débats, 24 January 1862.

${ }^{42}$ Flahault to Thouvenel (Private), 20 January 1862. AMAE: PA-AP 233 Thouvenel.
} 
armed forces, show that this was not Napoleon's intention and that his aims had not changed from those expressed the previous October:

Il est contraire à mes intérêts, à mon origine et à mes principes, d'imposer un gouvernement quelconque au peuple mexicain: qu'il choisisse en toute liberté la forme qui lui convient; je ne lui demande que la sincérité dans ses relations extérieures, et je ne désire qu'une chose, c'est le bonheur et l'indépendance de ce beau pays sous un gouvernement stable et régulier. ${ }^{43}$

These sentiments were to be emphasised many times by Napoleon in the next two years, particularly in his instructions to his commanders and in his negotiations with Maximilian.

Despite his declarations, rumours that Napoleon did intend to impose a monarchy were fuelled by reports such as that of a conversation between a British Colonel Claremont and Colonel Valazé, who was to accompany General de Lorencez. Claremont said to Cowley:

Although Colonel Valazé made no secret of the object of the expedition, yet it might injure him if it were known that he had made me acquainted with it. He distinctly told me that the Emperor had informed him they were going for the purpose of proclaiming the Archduke Maximilian of Austria King of Mexico, and he is under the impression that this has been agreed upon with Her Majesty's Government who are to furnish a proportionate contingent of troops. 44

The British Government had of course no intention of sending more troops to Mexico, so this part of Valazé's "revelation" can be discredited as rumour, and there is no available evidence to show that Napoleon had given instructions to de Lorencez which were contradictory to those cited above. It is also highly doubtful that Napoleon would have confided his intention, if it were true, to a subordinate officer. But accounts such as this led both the Spanish and English governments to deny prior knowledge of the proposal, and although they were motivated to do this by their internal political situations, they justified their denial on the ground that the discussions that had taken place in the previous months had been "secret" or informal. Russell wrote to Crampton:

\footnotetext{
${ }^{43}$ Napoleon to Lorencez, quoted by M. Billault, Minister without portfolio, to Corps législatif, 26 June 1862. A.D., Vol. 8, 1862, pp. 209-210.

${ }^{44}$ Colonel Claremont to Lord Cowley, January 21 1862. PRO: FO 27/1431.
} 
I do not understand that the French Government have proposed the Archduke Maximilian as a candidate for the Throne of Mexico. They have not made any such proposal to the British Government. They have asked whether in case the Mexican people should choose the Archduke for their King Great Britain would oppose such a settlement. Her Majesty's Government said they would not oppose the wish of the Mexican people but they should not take any part in promoting such an arrangement. 45

Palmerston was quick to reassure his parliament that England would limit its operations to obtaining reparation for the outrages committed against them and that the allied intervention would not degenerate into an opportunity to impose a particular form of government that the Mexicans did not want. The desire of the government, he said, was to see established in Mexico a government with which foreign nations could treat and with which they could maintain peaceful and friendly relations. This was the limit of the aims of the British government, which Palmerston believed was also the desire of the speakers on both sides of the chamber. ${ }^{46} \mathrm{He}$ therefore publicly distanced himself from the discussions that had taken place with France over the possibility of seeing a monarchy established in Mexico.

Collantes also denied knowledge of the proposal of a monarchy and of Maximilian as a suitable candidate, but Mon was to challenge him over this in the Spanish Cortes a year later, and accuse him of jeopardising the expedition by his action. Collantes justified his behaviour on the grounds that the initial discussions were secret, but observers such as Crampton, and Mazade, who followed Spanish political events closely, commented that his behaviour was more to do with protecting the government from attack by the Cortes. Collantes wrote to Prim that the proposal of establishing a monarchy in Mexico was gaining ground but the French Government had made no formal proposals in this regard to the Spanish Government, and besides Spain had no intention of disregarding the fundamental principle of Spanish politics in America; that of leaving the Americans complete freedom to choose the government most suited to their needs and opinions. ${ }^{47}$

\footnotetext{
45 Russell to Crampton (Telegram), 2 February 1862. PRO: FO 72/1028.

${ }^{46}$ Palmerston to the House of Commons, 6 February 1862. Reported in Journal des Débats. 9 February 1862.

${ }^{47}$ Collantes to Prim, 22 January 1862. A.D., Vol. 7, 1862, p.347.
} 
It would seem that Collantes was motivated by the hope that a Bourbon Prince would be chosen for Mexico, and he knew the Spanish people supported this idea. Mon reminded Collantes that he had been told of the suggestion of Maximilian the previous October, but in all his responses to Mon's private letters between October and December 1861 which had mentioned both these proposals, Collantes had cleverly refrained from acknowledging any mention of Maximilian. He had instead remarked after one of Mon's letters that the Mexicans should be free to choose whomever they pleased for a monarch if that was what they wanted, but Spain felt a Bourbon prince would be an appropriate choice given its historic ties with Mexico. ${ }^{48}$ Charles de Mazade commented at this time, "Le nom de l'Archiduc Maximilien est accueilli à Madrid avec une amertume mal déguisée, qui laisserait croire à quelque espérance trompée". 49 It would seem that Mazade had made an astute observation, for Crampton commented similarly when responding to Russell's request to know Spain's views about the French idea. He said of the Spanish Government:

They feared that if that plan went forward the opposition here would fall upon them as having been duped and made a cat's paw of to place a German Prince upon a throne, which if erected for anybody, Spaniards think ought to be given to a Spaniard. 50

Collantes, it appeared, was protecting himself and his Government against attack from the opposition and he maintained his silence until forced to do otherwise when challenged in the Senate in January 1863. He was compelled then to reveal four letters Mon had written to him, each of which spoke of Maximilian and each of which had been edited before presentation to the Cortes in June 1862, or had been suppressed altogether. He did so with the comment:

Si je n'ai pas fait ces révélations plus tôt, c'est que le secret m'avait été demandé, et il n'est pas dans mon habitude de trahir les secrets qui me sont confiés. ${ }^{51}$

\footnotetext{
${ }^{48}$ Collantes to Mon, 9 December 1861. Ibid., pp. 314-315.

${ }^{49}$ Charles de Mazade, "L'Expédition du Mexique", p. 770.

${ }^{50}$ Crampton to Russell (Private), 4 February 1862. PRO: PRO 30/22/86, Russell Papers.

${ }^{51}$ Collantes to Spanish Cortes, 8 January 1863. A.D., Vol. 10, 1863. pp. 54-55.
} 
The reason he claimed it as a secret was the fact that Mon had written confidentially to him on the subject, which, as Mon reminded him was the normal practice when it was not desirable to make something public knowledge, but the confidentiality of the letters was not a justification for denial of his knowledge. Collantes also used a statement of the French Minister Billault to the Corps Législatif in June 1862, to defend his silence. Billault had said that the idea of the candidature of the prince Maximilian had only been indicated in a diplomatic conversation and as a possible outcome of the expedition. According to Collantes, the Spanish Government had considered the idea purely from this point of view and not taken it too seriously. 52

How then had Napoleon got himself into this situation where his motives relating to Maximilian created suspicion among his neighbours? And why was secrecy maintained for so long? There are reasonable explanations for both of these questions, but there was also a fair measure of phobia, jealousy and mistrust on the part of his opponents. As Billault also said to the Corps législatif in June 1862, Napoleon did not suggest a likely prince for Mexico until he had obtained agreement from the other governments that none of them was seeking advantage for itself in Mexico. A prince from an unrelated family would prevent any rivalry among the three nations, but would only be proposed if Mexico voted in favour of a monarchy and a foreign prince. ${ }^{53} \mathrm{In}$ his letter to Flahault in October 1861 Napoleon had mentioned Maximilian and said the Mexican emigrants, in their eagerness, had already approached Austria with a request to Maximilian and this, I believe, put Napoleon in a difficult position because he wanted to keep all negotiations quiet until agreement was obtained from Austria, and until the situation in Mexico was ascertained. This is supported by a conversation between the Duc de Gramont, the French Ambassador in Vienna, and Hammond, the English UnderSecretary of State for Foreign Affairs. Gramont told Hammond that he had been the "indirect organ" with whom the Austrian government had been communicating regarding Maximilian, "but that all had passed quite unofficially, and in fact . . . the Emigrants in

\footnotetext{
52 Ibid., p. 54.

${ }^{53}$ Billault to Corps Legislatif, 26 June 1862. A.D., Vol. 8, 1862, pp.176-177.
} 
Paris were the prime [movers] of the whole affair."54 Russell also accepted that it had been the Mexicans who had put the process in train and observed that "this class of people are notorious for unfounded calculation of the strength of their partizans [sic] in their native country, and for the extravagance of their expectations of support." 55

Napoleon was motivated also by concern that the Austrian government not be compromised by the open discussion of the proposal of Maximilian before the situation in Mexico became clear. In a conversation with Metternich the previous November, Napoleon had acknowledged there was a possibility that a monarchy would be rejected and he had wanted to ensure that the name of Maximilian was not put forward before the right moment and that the Austrian government not be seen to be involved in the negotiation of the proposal. By keeping negotiations with them quiet they would be protected from criticism if the proposal was rejected. Because of his efforts in this respect, and in spite of discussions with the other governments on the subject, Napoleon was accused of misleading his allies and intending to impose a monarchy come what may.

In the wake of the open discussion of a monarchy, widely diverse opinions were expressed regarding its feasibility and its suitability for Mexico. The English Ministers were of course among the most sceptical, and Russell remarked to Bloomfield, his Ambassador in Vienna, that if "our estimate of the disorganization of Mexico is correct, the Archduke, if he were to assume the Crown, would have to rely wholly on the support of the French troops." He also said that O'Donnell was in agreement with him that the idea of establishing a monarchy by foreign intervention was "chimerical" as it would simply collapse as soon as foreign supporting troops were withdrawn. ${ }^{56}$ Yet while Russell was saying this, The Times was publishing letters from its correspondent in Mexico who said that it was impossible for a Republican form of government to prosper

\footnotetext{
${ }^{54}$ Hammond to Russell (Private), 8 February 1862. PRO: PRO 30/22/41, Russell Papers.

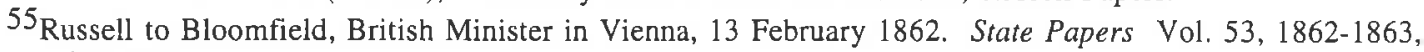
pp. 389-390.

$56_{\text {Ibid. }}$
} 
in such a country and what they needed was an "enlightened despotism". The correspondent added that "although there might be prejudices to overcome at the outset, the educated and respectable portion of the inhabitants will soon be able to appreciate the advantages of a firm, paternal government." 57 Three weeks later he wrote again, saying that a monarchy supported by the three European Governments was the only form of government that could effectively ensure a resistance to the encroachment of the Northern Republics. To be successful though, it needed to "blend the influential and respectable of all parties", who, "almost without exception are in favour of a monarchy". 58

The opinions being expressed in the French press, however, were somewhat different. Le Temps commented that although the three Powers had declared they only wanted to obtain compensation for wrongs and did not intend to impose a government contrary to the wishes of the Mexican people, public opinion was not without some concern in that respect, despite the support given to the idea of a monarchy by some French and foreign newspapers. The article claimed that the idea that a monarchy was best for Mexico was based mainly on stories of the anarchy that had resulted in over fifty governments being formed in forty years. But the European public did not really know or understand Latin America, and the reality was that to the "peoples of these countries" the form of government did not really matter if they could get on with their lives and making a living. ${ }^{59}$ Mazade was also sceptical of the possibility of success, not so much in establishing a Monarchy, but in making it last in such a "tormented" country. The presence of their troops in Mexico would easily lead the people to pronounce in favour of a more stable regime, and it would not be difficult to obtain a vote in favour of a monarchy, especially with a candidate to propose, he said. But an occupation of indeterminate duration would be inevitable in such an unstable country, and European politics would be involved in an enterprise the dangers and proportions of which they could not predict. 60

\footnotetext{
${ }^{57}$ The Times Correspondent in Mexico, 29 December 1861. The Times, 30 January 1862.

${ }^{58}$ The Times Correspondent in Mexico, 20 January 1862. The Times, 4 March 1862.

${ }^{59}$ Le Temps, 26 February 1862.

${ }^{60}$ Charles de Mazade, “L'Expédition du Mexique”, pp. 768-769.
} 
Needless to say the United States was very much opposed to the idea of a monarchy in Mexico, and Secretary of State Seward advised his Ministers in Europe that such a regime had no chance of enduring, particularly with a European monarch who would need to be sustained by European alliances. Because the monarchical system was damaging and hostile to the system prevailing in the Americas, it was more likely to be the beginning rather than the end of revolution in Mexico. It was inevitable then that the permanent interests and sympathies of the United States would have to be with Mexico. Seward added that the emancipation of the American continent from Europe had been the principal characteristic of the previous half century and it was not likely that a revolution in a contrary sense would now be successful. ${ }^{61}$

It can be seen that opinion in Europe was fundamentally divided on the issue of the establishment of a monarchy in Mexico, yet the opposition of both the Spanish and English governments was still couched in terms that led Napoleon to believe they would support a monarchy as long as it was the free wish of the people - which was exactly what Napoleon was proposing. But already control of events in Mexico had slipped from the hands of the governments, and even greater differences than those between the governments themselves were to emerge between their representatives in Mexico. These differences encompassed not only each one's interpretation of his own government's wishes, but also their individual assessments of the situation in Mexico and the appropriate actions to take. The suspicions each had of the others, as well as their individual ambitions, were to lead the expedition in a direction that would have been impossible for Napoleon, or anyone else to predict or plan for. In addition there was the problem, impossible to overcome, of the time needed for correspondence to travel between Europe and Mexico which could mean a lapse of two months between sending a report or instructions and receiving a reply at either end. So while Europe was responding to the early arrival of the Spanish forces and issuing appropriate instructions,

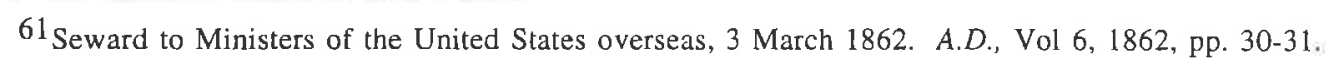


the Allied Commanders had arrived in Mexico, made decisions of their own and begun action which was to disturb their governments. 


\section{แbapter 4}

\section{a tife ำ Jts Oma}

It is at this very early stage in the campaign that it can be seen how important were the roles of the Plenipotentiaries and just how much responsibility they took upon themselves. Although my focus is primarily on the French representatives, both Wyke and Prim used their own initiative to take action diametrically opposed to their governments' wishes. The dilemma was that all three had been given rather elastic instructions in that it was recognised that the circumstances they encountered on their arrival would determine some of their actions. At the same time the guidelines and basic principles of their instructions were fairly clear. As seen in the previous chapter Russell had recognised the need for "commanders acting at a distance ... to be closely watched", and Thouvenel commented to Cowley on the difficulty of sending "instructions relating to matters which had occurred two months before comments on them could be read." 1 But although they were aware of the inherent problems it was impossible for the governments in Europe to maintain adequate control of what their representatives were doing. Their very first action was to astound all three governments.

Upon their arrival in Mexico on 9 January 1862 Prim and Jurien met with Wyke to discuss "the best means to be adopted for carrying out the intentions of the allies", and Wyke was pleased to find Prim agreed with him that they should try "every measure of conciliation" before resorting to force. In reporting this meeting to Russell, Wyke said that both Prim and Jurien agreed

that our first duty was to aid and assist the Mexicans in obtaining such a Government as was likely to afford more efficient protection to the lives and properties of foreigners resident in the Republic, before exacting from such a Government the execution of those engagements towards foreign Powers which their present penury and hopeless state of disorganization does not permit them to fulfil. ${ }^{2}$

\footnotetext{
${ }^{1}$ Cowley to Russell, 6 March 1862. State Papers Vol 53, 1862-1863, p. 435.

2 Wyke to Russell, 16 January 1862. Ibid., pp. 395-396.
} 
The proclamation issued as a result of these discussions stated that while they had come to demand retribution for debts and other wrongs, the three nations had a higher motive and that was to extend a friendly hand to them to help bring an end to the perpetual civil wars of past years. The presence of the allies was their chance for salvation, it said, and the Mexicans were asked to trust their good faith and generous intentions as their only aim was to assist in the regeneration of the country. ${ }^{3}$

Despite the apparent uniformity in the views of the Plenipotentiaries, there was in fact silent disagreement on the part of Jurien and Saligny. Jurien expressed his opinion immediately in a letter to Thouvenel, but Saligny's was not to be made known until much later, and then in a rather destructive manner. Jurien wrote that Prim had written the proclamation because he was the only one who spoke Spanish. When it was translated, however, Jurien objected to some aspects as they did not really reflect French views. He commented that in any meeting where people express the desire to agree it is always the one who holds the pen who succeeds in having his ideas prevail. For his own part, Jurien was disposed to let Prim expose his ideas in order to know what they were, and as a result the proclamation was entirely the work of Prim. ${ }^{4}$ Although he did not specify his objection, in the light of his statement at the next conference it can be assumed that it was to the implication that they would assist the present government in its work of regeneration.

Apart from this silent disagreement, it soon became obvious that there were serious differences among the allies. Having stated their intentions to the people, they awaited an escort to take them to Mexico City to deliver a collective note to Juarez, the content of which was affected by discussions which revealed dramatic discord among them. Jurien told the other representatives that he believed the Mexican policy was to keep the allies on the coast where they would be decimated by disease and he pointed out they had to find a way of waiting in a more healthy region to decide what to do. Commodore Dunlop

\footnotetext{
${ }^{3}$ Proclamation to the Mexican Nation, 10 January 1862. A.D., Vol. 7, 1862, pp. 359-360.

${ }^{4}$ In report of Jurien to Thouvenel, 12 January 1862. Copy with report to Minister of Marine and Colonies, 15 January 1862. AN: BB $^{4} 799$.
} 
agreed to march inland with the French, but Prim said there was no precedent for a nation allowing another who was intervening in its country to move inland to a more strategically advantageous position en route to the capital. If the Mexicans refused their request, Prim said, they did not have the means to undertake a battle and ultimately win. The others agreed he was right and finally decided to send a petition to General Oraga, one of Juarez's ministers, in this regard.

Jurien had then proceeded to outline to his colleagues his view of the aims of the intervention, which included the need for a change of government and, he believed, the institution of a monarchy. Jurien's confidential instructions, however, had suggested that though this was a preferred option action to assist this eventuality could only be taken if "a considerable party appears" looking for their help to effect such a result. 5 Jurien told his allies that they all recognised that the amount of the reclamations they had to present to Mexico would absorb for a long time the major part of the country's resources and it was also likely that their demands would be accepted by the government but treated no better than all treaties had been by the precarious governments of the past. What was needed, therefore, was a more stable government that would be able to guarantee that their conventions would be satisfied. Their first objective then had to be to found a better state of things in this country, said Jurien, for they had no other means of preventing the periodic return of costly expeditions to Mexico.

Prim's response revealed that both he and Wyke had views that were in opposition not only with Jurien but also with the governments of all three of them. Prim had replied that the Mexicans would never want a monarchy and that it was his belief that the Liberal Party, Juarez's party, had more support in Mexico and was the only one that could gain the sympathies of the people. Consequently it was the only one he was interested in sustaining and consolidating, and he was supported in this by Wyke. Prim apparently told Jurien that he had wanted to support France but the most important person in Mexico

\footnotetext{
5Thouvenel to Jurien (Confidential), 11 November 1861. AMAE: CP Mexique, Vol. 57, quoted by Carl H. Bock, Prelude to Tragedy, p. 522.
} 
was Doblado and he was staunchly republican. Jurien concluded his report of these discussions with the following comment:

Je me trouve donc en présence de difficultés que Votre Excellence n'avait pu prévoir. Prêt à marcher d'accord avec l'Espagne, je ne soupçonnais pas que l'Espagne ne marcherait pas d'accord avec elle-même. Il faut bien le dire, cependant, tout avait été disposé pour rendre ici le Général espagnol l'arbitre de la situation en lui laissant le contingent de beaucoup le plus considérable, le grade le plus élévé entre les Commandants alliés. ${ }^{6}$

Although Prim's and Wyke's view prevailed it was to be attacked by all three governments, and the differences between the plenipotentiaries changed forever the course of the expedition.

It seemed that the vigour espoused in Collantes's determination to spearhead strong action against Mexico, and evident in the early arrival of the Spanish forces, was to dissipate under the leadership of Prim. As Jurien noted above, he was amazed to find "Spain was not acting in agreement with itself", so it is perhaps necessary to understand a little about Prim to appreciate what had already happened, and what was about to happen under his leadership. Prim was from a rather modest background and began his military career as a volunteer in the civil war from 1833-1840, in the free corps of Catalonia. After the war he was nominated as a deputy, and in 1843 he entered the regular army as a brigadier to suppress an insurrection in Catalonia. He was then given the title of Conde de Reus, after the town in which he was born. He had a distinguished career in Puerto Rico and Turkey and became a deputy to the constituent assembly on his return to Spain. A Liberal, he united with O'Donnell, became a lieutenant-general, and was made Marquis de Castillejos and Grande of Spain after the successful Moroccan campaign in 1861 .

Mazade, who had observed Prim in Spain and took a keen interest in the Spanish political situation, saw him as totally ambitious and suggested he had to have a motive for asking for the command in Mexico. He suggested that it was that Prim had aspirations to 
become dictator or king of Mexico himself, and there were many rumours abounding in Havana and in Mexico that this was so. ${ }^{7}$ A report from the captain of one of the French frigates gave an account of the welcome given to Prim on his arrival in Havana, in which triumphal arches were erected and the general had been crowned in effigy in some streets, amid cries of "Viva el Vice-Roy de Mexico! El Nuevo Hernan-Cortez." 8 In Mexico he and his wife, whose uncle had recently been appointed Minister of Finance in Juarez's government, were treated as royalty, and one of the newspapers had even voiced the idea of Prim as Emperor. Prim denied such claims, saying his ambition was related purely to Spain. It was also suggested that his family ties with the government persuaded him to negotiate with Juarez instead of following his instructions. Whatever his reasons, it was obvious that Prim intended to follow a different path to that advocated by his government. It may have been that he saw his relationship with a member of the government as an opportunity to resolve the question without resorting to war, and to gain prestige with his own government by doing so. Regardless, he probably did not anticipate opposition from the French in pursuing the path he chose.

In the second allied conference a further instance of disagreement arose when the French claims were presented and considered suspect because of the amount involved. They were rejected by the English and Spanish representatives because of the inclusion of claims on behalf of a Swiss banker, Jecker and Company. In 1859 the Miramon government issued bonds to the sum of fifteen million pesos, to be underwritten by the bank Jecker Torre and Company, one of the leading banks in Mexico, and guaranteed by the government. Incentives were offered to foreigners to invest in the bonds, but when Jecker and Company collapsed in Paris in May 1860 only 700,450 pesos worth of bonds had been sold. After Juarez defeated Miramon his government refused to recognise the bonds floated by the previous government and pay the interest on them. When Saligny included the claims of the bondholders in the French demands he nominated an amount far in excess of the value of the bonds sold, which was bound to incite a reaction from

\footnotetext{
${ }^{7}$ Charles de Mazade, "Le General Prim", R.D.M., Vol. 61, 15 January 1866, pp. 540-544.

${ }^{8}$ Captain of Lavoisier to Chasseloup-Laubat, 3 January 1862. AN: $\mathrm{BB}^{4} 799$.
} 
his colleagues. ${ }^{9}$ Wyke and Dunlop reacted angrily to their inclusion saying they were ${ }^{4}, z^{2}$ inadmissible because they had been contracted by Miramon's Government, and would never be accepted by the Juarez or any other government. Wyke claimed just demanding the fulfilling of this contract would cause the Mexicans to break any agreement with the allies, for they would rather suffer the consequences of war than the ignominy of acceding to such an unjust claim .

As the situation could not be resolved in the meeting of 14 January, it was suggested, by Prim, according to Jurien, that in the note they were to address to Juarez they state that though they had to demand full reparation for past wrongs, the first thing to do was to help the Republic constitute itself in a stable manner which would give it the chance to be able to meet its engagements. This of course was similar to what they had said in their proclamation. In reporting this meeting to Collantes, Prim declared that the English and French Commissioners agreed this was the only action to adopt in spite of their formal orders. To justify the decision Prim outlined the alternatives that had been open to them :

Nous nous trouvions dans l'alternative de ne pas envoyer nos commissaires à Mexico, après avoir demandé une escorte qui depuis ce matin les attendait à nos postes avancés de la Tejeria, ce qui nous aurait enlevé tout prestige et aurait donné à entendre qu'il avait surgi entre nous un grand désaccord, ou bien d'envoyer nos commissaires sans modifier l'ultimatum français.

Sir Charles Wyke s'opposa de toutes ses forces à ce dernier parti, et je confesse que, pour ma part, je ne pouvais me résigner à ce que l'influence de notre noble et généreuse nation et le sang de nos soldats fussent employés à précipiter dans une ruine totale ce malheureux pays en soutenant des réclamations aussi injustes. ${ }^{10}$

The collective note to Juarez was thus composed along the lines suggested by Prim. They said the role they were given by their governments was to demand reclamation for the past and obtain guarantees for the future, but the representatives themselves did not

\footnotetext{
${ }^{9}$ Ralph Roeder, Juarez and His Mexico, Vol. 1, p. 280. Various assertions were made that Saligny was instructed to include the Jecker bonds in the French claims to make their demands impossibie to be met by the Mexican government. However, there is not enough evidence to support this, nor any obvious reason why Napoleon would be interested in Jecker. The Duc de Momy was apparently involved with Jecker, but that is unlikely to have interested Napoleon. Saligny's alleged friendship with de Morny has been given as one reason for pressing the claims, while another suggestion was that de Gabriac, Saligny's predecessor, had lost a large amount of money in Jecker's collapse and Saligny pursued the claims for him.

10 Prim to Collantes, 14 January 1862. A.D., Yol. 7, 1862, pp. 362-363.
} 
believe this was enough. Taking into consideration the actual state of Mexico they believed their mission could have "a higher aim and a more generous result". They went on to say that these three great nations were here now to be witness to, and if need be, protectors of the regeneration of Mexico, and to assist its organisation without interfering in any way in the form of its government or of its internal administration. ${ }^{11}$

Juarez rejected their opinion of the situation in Mexico, saying that as all the states of the confederation were behind his government Mexico had no need of regeneration, and showed that he was not going to capitulate to the idea of dissolving his government. He then effectively quashed any likely movement of a group wanting to overturn the government by issuing a decree imposing the death penalty on any Mexicans who assisted the intervention in any way, be it military, political or economic. In his reply to the allies he said he was prepared to satisfy just demands, and that respect for its engagements would be one of the invariable rules of the Liberal administration. The Plenipotentiaries were then invited to come to Orizaba with an escort of two thousand men and to re-embark the rest. The allies refused this latter request but announced they intended to go to Orizaba and Jalapa to find a more healthy camping site for their troops while Prim made contact with Doblado. Juarez did not then insist on the re-embarkation of troops but arranged for Doblado to meet with Prim, a meeting that was to result in the conclusion of the controversial Preliminaries of Soledad. ${ }^{12}$

On hearing of the proclamation and negotiation with Juarez the three governments were equally astounded at the action taken by their envoys. Napoleon reacted angrily and had Thouvenel communicate that he "regretted" that instead of immediately pursuing reparation for the wrongs committed by the Mexicans they had addressed a note to the government which gave it time to organise its resistance and to conduct a pretence of consultation of the wishes of the nation. He believed that the question of reorganisation could only be usefully proposed and resolved after the City of Mexico or its environs had

\footnotetext{
11 Collective letter to the Juarez Government, 14 January 1862. Ibid., pp. 364-365.

${ }^{12}$ Émile Ollivier, L'Empire libéral, Vol. 5, pp. 369-370.
} 
been occupied. Napoleon hoped they had not been stopped from moving forward by an evasive and deceptive response from Juarez, and that they would have already marched on the capital as quickly as their means allowed. Jurien was further advised that his concessions to agreement with their allies did not have to go as far as accepting satisfaction for less than what he considered were France's legitimate demands, although this reaction was tempered in Thouvenel's next despatch. If Spain and England insisted on not supporting French claims, Jurien and Saligny were authorised to leave their colleagues to treat separately, and to pursue alone the reparation due to France, taking into account, however, the needs of their military situation and the general state of things in Mexico. They were cautioned, however, that such a decision was not to be taken lightly, but only as a last resort and after considering the chances of success of action taken alone. ${ }^{13}$

This advice was not received by Jurien until 3 April and in the meantime he had made his own observations on Mexico and begun to consider the idea of separating from his allies. He wrote to Chasseloup-Laubat describing the difficulties they had already encountered and suggested that the Emperor and his government "would probably have to decide whether it was better to conclude the Mexican question quickly, by whatever means, or whether it was preferable to support the hopes they had encouraged by preparing their own small army to do without the Spanish contingent."14 Just why Jurien had decided so quickly what he intended to do is difficult to say. He had arrived in Mexico only on 9 January and within a few days he declared a monarchy was best for Mexico and considered separating from the Spanish contingent. It may have been that the Mexicans' fear of Spain's intentions suggested that a satisfactory solution could only be achieved if France acted separately from them, because the Mexicans were relatively happy France was represented there. Another reason may be that Prim had stated Juarez's Liberal government was the only one able to save Mexico, and he was not likely

\footnotetext{
${ }^{13}$ Thouvenel to Jurien, 21 February 1862, coded telegraphic despatch sent via Cadiz. (r. 3 April). AN: BB 4 1817 bis.

14Jurien to Chasseloup-Laubat, 12 January 1862. AN: $\mathrm{BB}^{4} 799$.
} 
to support the monarchy that Jurien quickly became convinced would be accepted. The answer may also lie in the character of Jurien himself, as described by Émile Ollivier:

Esprit cultivé, écrivain distingué, doux, poli, conciliant, d'une scrupuleuse loyauté, ne cherchant qu'à s'éclairer, mais courtisan et soldat discipliné, incapable de résister à ce qui ressemblait à un ordre ou même à un désir de son souverain. ${ }^{15}$

Perhaps these qualities made him too eager to achieve what he had been told to pursue with caution, and only if the opportunity was provided by the people.

In the meantime the initial reactions of all three governments were to oppose the actions taken by their Plenipotentiaries. Thouvenel wrote to Flahault in London to express his great concern at the actions of their representatives, and to clarify with Russell whether each nation's claims had to be agreed by its allies. In part he said of the proclamation:

Emprunté d'une fâcheuse apparence d'irrésolution, elle donne au Cabinet de Mexico les moyens de gagner du temps et d'organiser la résistance. Il ne manquera pas d'y voir une preuve de faiblesse que lui rendra cette confiance orgueilleuse en lui-même contre laquelle toutes nos tentatives de conciliation ont échoué dans le passé. L'expérience que nous avons acquisé de la manière de penser et d'agir ne nous permet pas d'en douter. Nous courons le risque de nous trouver ainsi en présence de difficultés qu'avec plus de décision les commandants de nos forces sauraient prévenir. ${ }^{16}$

Russell agreed entirely with these views and said he would send directions to Wyke similar to those sent to Jurien, but even though he reprimanded Wyke for his actions, he said he would reserve his final opinion until he had received Wyke's explanations. ${ }^{17}$ Collantes also agreed with Thouvenel's criticisms and remarked that by negotiating with Juarez they had recognised his Government as legitimate and discouraged the sound part of the population from seeking the assistance of the allies. ${ }^{18}$ As far as their claims were concerned Russell told Flahault he thought each nation had a right to determine the extent of its own claims. Flahault then suggested that after the claims had been accepted in principle by the Mexican Government, France would be happy to have a special

\footnotetext{
15 Émile Ollivier, L'Empire libéral, Vol. 5, p. 249.

${ }^{16}$ Thouvenel to Flahault, 22 February 1862. AMAE: CP Angleterre, Vol. 721.

17 Russell to Wyke, 25 February 1862. Siate Papers Vol. 53, 1862-1863, p. 393.

18 Barrot to Thouvenel, 26 February 1862. A.D., Vol. 9, 1863, p. 317.
} 
commissioner determine the exact amount which would satisfy their claims. Russell accepted this idea and said he would "invite Wyke to withdraw his opposition".

After learning the reactions of the other two governments Thouvenel wrote to both Jurien and Saligny criticising the priority given to establishing a new government, and revealing that the demands made by Saligny were not necessarily those of his government. Firstly he said that the three Powers would not have sent their naval squadrons and troops if there had been the least chance of gaining satisfaction by continued negotiation. Jurien was authorised to go inland and to determine with Saligny whether the reparations they had to demand were to be the object of their preoccupation from now on, and whether those demands could be modified. To Saligny he said that while it had never been said that each nation's claims had to be scrutinised and approved by the others, it might be necessary to prioritise some of the French claims and decide the importance of others. Thouvenel felt they had to decide what was more important, having their own demands met, while seeking neither personal advantage nor territorial acquisition, or maintaining the spirit of the Convention. ${ }^{19}$

It was obvious, though, that at this point the maintenance of the Convention was the priority of the French government. Thouvenel told Saligny that his department had not assessed the value of France's complaints as highly as he had, although they did not have enough information to dispute them. While he did not necessarily want Saligny to reduce the figure to which Wyke and Prim objected, he might be a little less "rigorous" on this point if it was an evident cause of disagreement among the representatives of the three Courts. As far as the Jecker bonds were concerned, Thouvenel thought a distinction should be drawn between those that affected French interests directly and those that affected other nationals, and as they had been contracted by Miramon it was important to ensure any claims in this respect would be accepted by the present government as being their responsibility.

${ }^{19}$ Thouvenel to Saligny, 28 February 1862. Ibid., pp. 304-305. 
The consequences of the behaviour of the plenipotentiaries were recognised by other observers, and a letter from Vera Cruz was published in the Moniteur in March 1862 with the obvious aim of showing that the expedition was taking a turn contrary to the Emperor's intentions and those of the English and Spanish Governments. The author was not named but it is possible that it was Captain de Challié of the French naval station, some of whose earlier reports had been published in the Moniteur. I suggest this because the report is much more informed than one would expect from an ordinary

French resident in Mexico. In commenting on the proclamation to the Mexicans he said:

au lieu de réclamer le redressement de leurs griefs respectifs, ils ont été demander naïvement au gouvernement de Juarez de se suicider, et, sans prendre aucune garantie, sans avoir aucun moyen de contrôler le sentiment national, ils font un vague appel au peuple mexicain, pour qu'il veuille bien changer son gouvernement et en établir un nouveau qui puisse offrir toutes les garanties désirables!

He commented also on the plenipotentiaries sending a note of their intentions to Juarez in Mexico City .

La mission qu'on a envoyée à Mexico n'a rien produit de bon. Les délégués ont été bien reçues, il est vrai, mais le brigadier espagnol a tenu des propos d'un tel radicalisme, qu'il a déroulé toutes les espérances des hommes d'ordre, qui attendaient avec impatience l'arrivée des alliés, dans l'espoir de voir un gouvernement régulier établi dans leur pays. ${ }^{20}$

The actions described here, and the decrees issued by Juarez, illustrate that it would now be difficult to know whether there was in fact popular support for a change of government, and public and opposition opinion in Europe would be swayed by this fact.

The three Plenipotentiaries, however, were to provide differing reports to their governments on the situation in Mexico, as well as on how the campaign should now be directed. Despite the fact he had seen no evidence of a strong opposing party, Jurien was convinced there was support for a monarchy. He wrote that a monarchy maintained by a foreign army was the only government that could save the country, but they had been misled in the belief that this could be "the work of a moment of surprise and the result of an intrigue". There were only two parties in Mexico, he said, the friends, and the

${ }^{20}$ Reproduced in Le Journal des Débats, 8 March 1862. 
enemies of the clergy, and the idea of a monarchy initially evoked fears that the privileges and power of the clergy would be supported once again. It was hard to believe the Clerical Party was likely to regain mastery of Mexico, though, when they had so far given no evidence of their existence, Jurien stated. In the light of these observations he cautioned Thouvenel against expecting an early result:

Vous voyez donc à quel point vous avez besoin de patience et de confiance en votre humble serviteur. Je ne réponds pas de réaliser votre programme dans toutes ses parties. Je le réaliserai certainement dans la plus essentielle, c'est-à-dire que je maintiendrai ici votre influence et que je ne vous engagerai pas malgré vous dans des frais qui seraient un terrible choc pour nos finances. Si mon plan vous agrée, ne négligez pas de me le dire. ${ }^{21}$

He went on to say he had to feel Thouvenel had complete confidence in him, and that he could act as an agent who was supported, approved and appreciated. If Thouvenel ever felt he did not deserve such treatment he should recall him, he added. Jurien's correspondence is often punctuated with such pleas for approval, which seems to suggest a measure of insecurity in his position so far from France.

In the next few days he was supported in his belief in the Mexican's desire for a monarchy by Captain Thomasset, the French delegate who went to Mexico City to see Juarez. He claimed he had seen men of all political persuasions, as well as foreigners from many nations, who all agreed there was no-one, and no single party in Mexico that could rally enough support to dominate. He believed, however, that the "moderate and honest men" of all persuasions were ready to rally around a monarchy "supported for some time, some years perhaps, by troops of the allied Powers". But for this movement to show itself the allies needed to have control of Mexico City and show their position was solid and backed by sufficient forces to deter the agitators of disorder and anarchy. ${ }^{22}$ With this in mind Jurien announced his plan of action to Thouvenel, saying he wanted to go to Jalapa to assemble enough resources to allow for an advance to Mexico City,

\footnotetext{
21 Jurien to Thouvenel (Personal), 24 January 1862. AMAE: PA-AP 233 Thouvenel, Vol. 10.

${ }^{22}$ Thomasset to Jurien, 31 January 1862, included with Jurien's reports of 28 January to Minister of Marine and Colonies. AN: $\mathrm{BB}^{4} 799$.
} 
recognise the current government purely as the de facto, but essentially transitory, government, and not discourage any party he encountered. He continued that he would laisser le général Prim et Sir Charles Wyke se bercer de l'espoir d'interroger le suffrage universel en lui dictant sa réponse et attendre ainsi que les gouvemements alliés s'expliquent. Je m'arrangerai pour leur en donner le temps. ${ }^{23}$

From this it would seem one of his objectives in deciding to act was to expose the duplicity of Prim and Wyke, as well as to separate the French from them in order to pursue what he saw as the Emperor's aims. He wrote to Chasseloup-Laubat in this respect:

Je me crée ici, peu à peu, un rôle isolée et fort important. Toutes les fautes commises par mes collègues tourneront, j'en suis sûr, à notre profit; mais ce serait une grande erreur de croire que l'on puisse agir brusquement sur les esprits et surprendre, par une marche rapide, une solution. ${ }^{24}$

Unfortunately for Jurien, in Paris they were expecting far more rapid progress than he thought appropriate.

Wyke's report, in contrast to Jurien's, was a justification of why they should continue to negotiate with Juarez and support his government. He believed it would be impossible for the country to find enough resources to satisfy French and Spanish claims as well as their own, until it was regenerated, "and the sooner therefore we set about helping them to effect this regeneration the better", he wrote to Russell. ${ }^{25} \mathrm{He}$ also reported that he had prevented Miramon, former Conservative President, from landing at Vera Cruz and could obviously see no contradiction, in his action, to the instructions from Russell that he was to show preference to no party in particular. He said:

The fact of our preventing Miramon's landing here will have the best effect throughout the country, for had we allowed him to organize an invasion under the protection of our flags, it would have been a cruel sarcasm on the friendly offers we have made to help the present Government in reestablishing peace and order in the country so that they may eventually be able to fulfil their engagements to us in the Republick [sic]. ${ }^{26}$

\footnotetext{
23 Jurien to Thouvenel, 24 January 1862. AMAE: PA-AP 233 Thouvenel, Vol. 10.

${ }^{24}$ Jurien to Minister of Marine and Colonies, 28 January 1862. AN: BB 499.

25 Wyke to Russell (Private), 31 January 1862. PRO: PRO 30/22/74 Russell Papers.

${ }^{26}$ Ibid.
} 
Surprisingly, Russell was not critical of the prevention of Miramon's landing, but he condemned the unwarranted belief of Dunlop and Wyke that regeneration of Mexico was their primary object. ${ }^{27}$

Wyke continued to express his confidence in this government that he believed to be gaining solidarity under Doblado, but his confidence was not reciprocated by Russell, who admonished him for not following instructions. Wyke wrote that General Doblado was using his influence to "centralize the powers of the government" and was filling "important posts with persons devoted to his policy". He concluded that the intervention was therefore indirectly having an effect, and he trusted it would not be long before there was "a strong and intelligent Government willing to treat with us and able to turn a deaf ear to the clamours of the mob". ${ }^{28}$ Russell, however, was not impressed by Wyke's arguments and wrote to Cowley that he could not "go along with Wyke about Mexican regeneration". 29 He accused Wyke and Dunlop of attributing to "Her Majesty's Government views and intentions diametrically opposed" to his instructions, and he believed their actions would adversely affect their future relations with Mexico. ${ }^{30}$

Prim's report of the situation was similar to Wyke's but the response of his government was to demand more forthright action. Prim wrote his conciliatory actions had begun to bear fruit and the Mexican people had begun to come around to the allies. It would not be long, he said, before they would be able to exercise their moral influence to obtain "the establishment of an order of things which was the result of the wish of the majority" and which would offer guarantees for the future. ${ }^{31}$ The previous day, however, Prim had written that the Mexican Government had imposed on foreigners a tax of two per cent on capital, which hardly implies a readiness to accept the intervention and help of the allies. Collantes responded that it was time to take decisive action, and

\footnotetext{
${ }^{27}$ Hammond, Under Secretary of State for Foreign Affairs, to Secretary of the Admiralty, 10 March 1862. State Papers Vol. 53, 1862-1863, pp.436-437

28 Wyke to Russell, 31 January 1862. PRO: FO 50/364.

${ }^{29}$ Russell to Cowley, 5 March 1862. PRO: 30/22/105, Russell Papers.

${ }^{30}$ Russell to Wyke, 11 March 1862. PRO: FO 50/363.

${ }^{31}$ Prim to Collantes, 31 January 1862. A.D., Vol. 7, 1862, p. 376.
} 
that order and confidence would not be restored until they marched inland and occupied Mexico City. ${ }^{32}$ He told Prim that his moderation to this point was approved by the government, but to temporise any longer would only prolong the expedition unnecessarily. It was now time for energetic and decisive action which should only be stopped when the desired guarantees were given. ${ }^{33}$

The differences that arose in Mexico between the French representatives on one side and the English and Spanish on the other, fuelled the suspicions of Napoleon's intentions that had already been evident in the minds of the English ministers before the expedition began. The extravagance of the demands put forward by Saligny, and Jurien's subsequent determination to separate from their allies, led Cowley and Russell particularly, to assert that Napoleon had intended all along to find an excuse to carry out his plan for a monarchy. Russell wrote to Cowley that he had heard that Saligny was told "to make a quarrel in Mexico any how and Mathew told me that upon being told on one occasion that Thouvenel would not approve of his conduct said 'What care I for Thouvenel, provided I please the Emperor?",34 Cowley added to this suspicion when he wrote to Russell three days later recounting "a very curious conversation with Metternich about the Archduke Maximilian". When discussing with him the "preposterous demands of the French", Metternich had commented that "these demands were made purposely", but Cowley did not reveal a specific explanation of this comment, other than that Metternich said the Emperor was keen to see Maximilian on the throne of Mexico. Metternich had added, however:

There is only one thing ... which I have not been able to ascertain, and that is his reason for taking all this trouble. We have taken care that he shall have no hold upon us and I defy him to find either in his own archives or in those of Vienna one line that can be turned to our detriment." 35

Cowley, though, saw in Metternich's comments further proof of his own opinion that Napoleon intended to ensure Maximilian was given the throne of Mexico in order to

\footnotetext{
${ }^{32}$ Collantes to Prim, 7 March 1862 (No. 86). Ibid., pp.374-375.

${ }^{33}$ Collantes to Prim, 7 March 1862 (No. 83). Ibid., pp.378-379.

${ }^{34}$ Russell to Cowley, 3 March 1862. PRO: FO 519/199, Cowley Papers.

${ }^{35}$ Cowley to Russell, 6 March 1862. PRO: FO 519/229, Cowley Papers.
} 
procure the annexation of Venetia for Italy. This issue was mentioned by the Duc de Gramont, the French Ambassador in Austria, in a conversation, referred to in the previous chapter, with the British Under Secretary of State for Foreign Affairs. Gramont had said that nothing had passed in the negotiations

which could be turned into the story which had got into the Viennese newspapers that Mexico was to be considered a set off against Venetia and a compensation to Austria for the cession of their Italian possessions; and that his Government was perfectly well aware that it was useless at present to enter on a discussion of the question of Venetia. ${ }^{36}$

Of course this does not prove that Napoleon did not intend to make use of the proposal for this purpose, but later analysis of his foreign policy will show that this was not his reason for wishing to help Mexico. Cowley added another reason for Napoleon's "pertinacity" regarding Mexico, of which he "had not a doubt", and that was "to please the Empress. It pays for other sins both of omission and commission, and helps to keep her quiet." 37 Cowley may not have been alone in thinking this, but there is little to support this opinion other than conjecture and, in the light of all Napoleon's correspondence relating to Mexico, it is difficult to accept he would have been influenced to undertake a venture of this nature for such trivial reasons.

Despite Russell's and Cowley's opinions regarding the validity of the French claims and what they saw as deliberate inflation, Thouvenel had shown he was ready to moderate them and to have them examined by a separate commissioner in Mexico. ${ }^{38} \mathrm{He}$ wrote to Saligny that he had advised the English government it would not be appropriate to make the demands so high their recovery became impossible, which refutes the claims made by Cowley and Metternich that this was what was intended by the French government, and he added:

En ce qui touche l'affaire Jecker, je ne saurais trop insister sur la distinction que je vous recommandais de ne pas manquer de faire entre ce qui, dans cette affaire, réclamerait bien légitemement notre protection, et les intérêts étrangers que nous n'avons pas, au contraire, mission de sauvegarder. ${ }^{39}$

\footnotetext{
${ }^{36}$ Hammond to Russell (Private), 8 February 1862. PRO: PRO 30/22/41, Russell Papers.

${ }^{37}$ Cowley to Russell, 6 March 1862. PRO: FO 519/229, Cowley Papers.

${ }^{38}$ Reported by Cowley to Russell, 14 March 1862. State Papers Vol. 53, 1862-1863, p. 440.

${ }^{39}$ Thouvenel to Saligny 14 March 1862. A.D., Vol. 9, 1863, pp. 314-315.
} 
Any mention of the Jecker bonds anywhere in the French or English archives demonstrates a candour on the part of Thouvenel regarding lack of detailed knowledge of them, and his determination that only those that affected French interests should be supported by Saligny. There does not appear to be enough evidence to support the accusations that the Jecker bonds were to be used deliberately to inflate the French claims.

Concern over the aims of the French government in Mexico was not confined to England, for the question was debated in the Corps législatif in March 1862 in the discussion on the Emperor's address to the Chambers. This procedure was a relatively new phenomenon in Napoleon's government, such reforms having been announced only in November 1860 , but the deputies had shown by their heated debates on the Italian question that they were ready to take on their new role without hesitation. The discussion on Mexico was opened by a little known deputy, Achille Jubinal, who was a member of "the majority", but Ollivier described him as "worthy on this day to be one of the Five."40 Jubinal demanded to know if the rumours that France had gone to Mexico to overthrow the republican government and establish a monarchy, were correct. If this were so, he asked what had happened to the great principle of non-intervention that France had proclaimed and defended elsewhere, and on what basis could they attack a country that was motivated by the same principles as those on which their own "great nationality" was based. ${ }^{41}$ Jules Favre, one of the most outspoken of Napoleon's opponents, followed this with a proposed amendment "expressing regret that the Mexican expedition seemed to have as its object an intervention in the internal affairs of Mexico, and praying the Government to reconsider its plans and stay within the limits

\footnotetext{
40 Émile Ollivier, L'Empire Libéral, Vol 5, p. 356. The "Five" referred to by Ollivier were the only opposition deputies at that time elected to the Corps legislatif. who included most notably Oltivier, who was later to head Napolcon's government; Jules Favres, a Republican law yer who in 1870 led the crowd to the Hotel de Ville to proclaim the Republic; and Adolphe Thiers, a tormer Minister of the Interior in the July Monarchy who had forceably put down a popular rising. He called mote loudly than orhers for more liberties to be granted by Napoleon during the 1860 s, but it was he who later authorised the soldiers to put down the Communards, killing thousands of them.

${ }^{41}$ Achille Jubinal to Corps législatif, 13 March 1862. Émile Ollivier, L'Empire Libéral, Vol. 5, pp.356-357.
} 
officially announced, and thus pursue only the reparation of its griefs." 42 It is rather ironic to realise that some of those who so strongly criticised Napoleon's government for intervening in Mexico were prominent members of the succeeding government that had few qualms about intervening in Tunisia, Tonkin, Madagascar and Morocco while supporting similar interventions by the United States and Britain. ${ }^{43}$

Favre continued attacking the government, but his claims were to be refuted by Billault, Minister without portfolio, for the government. Favre said that they had not gone to Mexico as creditors but as invaders to enthrone Maximilian, and the claims of officers departing for Mexico that this was so, was the proof. Billault responded that the idea of enthroning Maximilian had nothing to do with the expedition, and it was hardly likely that "if such were the solemn secret and intention of French diplomacy it would be handed to troops for broadcasting." 44 He continued by stating that they were going only to impose respect for their nationals and fultilment of Mexico's engagements towards France, in pursuit of which it was essential to march to the capital. He then made an emotional appeal to the Chamber:

Est-il bien opportun, tandis que nos soldats marchent sur Mexico, de tenter de démontrer ici qu'ils ne sont que les instruments d'une intrigue et que la guerre dans laquelle ils vont verser leur sang est une guerre illégitime?

Ollivier commented that Billault finished his address with "a superb affirmation of victory: 'Nos troupes vont à Mexico; parties le 20 février, elles doivent déjà y être.' “45 This latter observation was based on a letter from Jurien which notified his intention to begin his march inland on 20 February and the government in its optimism had assumed he would already have reached that city. 46

Despite the views of the opposition, the words of Billault gained the support of the deputies who voted in favour of energetically prosecuting the expedition "till complete

\footnotetext{
42 Jules Favre to Corps législatif, 13 March 1862. Frank Lally, French Opposition to the Mexican Policy of the Second Empire (Baltimore, 1931), p. 37.

${ }^{43}$ Paul Gaulot, L'Expédition du Mexique, Vol. 1, p. vi

${ }^{44}$ Ibid., p. 38.

${ }^{45}$ Quoted by Émile Ollivier, L'Empire Libéral, Vol. 5, pp. 357-358.

46Jurien to Thouvenel (Personal), 7 February 1862. AMAE PA-AP 233 Thouvenel, Vol. 10.
} 
satisfaction had been procured for French nationals and interests in Mexico."47 This same support was reflected in the reports of the Procureurs Généraux, most of whom commented that although the aims of the expedition were not completely understood the people believed it was important to maintain their honour in Mexico. Once such report said:

La guerre du Mexique cause une certain préoccupation; on s'effraye des sacrifices d'hommes et d'argent qu'elle doit nécessairement entraîner, mais on reconnaît, en même temps, qu'il était impossible de ne pas demander réparation des nombreux griefs de la France contre le Gouvernement Mexicain. Notre drapeau est engagé; Au Mexique, comme ailleurs, il faut soutenir l'honneur de nos armes, et l'opinion publique s'est associée, avec énergie, au vote du Pouvoir Législatif. 48

Opposition as a result was briefly silenced as the campaign was not envisaged as a long one, but the news that was to reach France in the next two weeks, that a preliminary agreement with Juarez had been signed, and that the French troops were not in the capital, was to prompt much speculation. When the Convention was finally ruptured in April, the campaign, its aims and the extent of France's commitment were once again to be debated in the Chambers.

While awaiting the responses of their governments to their initial actions the allied representatives continued to make decisions, according to their own assessments of the situation, that were to cause further concern in Europe. After several conferences had been held, Wyke reported that he and Dunlop had convinced their colleagues that they should make a final attempt to achieve a pacific solution by allowing Prim to meet with Doblado. ${ }^{49}$ This meeting resulted in the drawing up of the Preliminary Convention of Soledad by Prim and Doblado, which was eventually signed by Prim, Wyke, Dunlop, Saligny, Jurien and Doblado on 19 February 1862. This document was an agreement on the intentions of each side, pending negotiations that would be opened at Orizaba on 15

\footnotetext{
${ }^{47}$ Frank Lally, French Opinion, p. 38.

${ }^{48}$ P.G. Rabou, Caen, 7 July 1862. Lynn M. Case (ed.), French Opinion on the United States and Mexico 18601867 (Archon Books, 1969,(c) 1936), p. 315.

${ }^{49}$ Wyke to Russell, 12 February 1862. State Papers Vol. 53, 1862-1863, pp. 453-454
} 
April, by which time the Plenipotentiaries would have received instructions from their governments.

The Preliminaries contained conditions that were to horrify all three governments, and included the following statements. Firstly, that the existing government had informed the allied commissioners that they had no need of their assistance as they had all the resources they needed to bring an end to their internal revolutions, therefore the allies had only to resort to their treaties to present all their grievances. Secondly, the allied representatives having said they had no intention of interfering with the sovereignty or integrity of the Mexican Republic, negotiations would begin in the city of Orizaba. The third article stated that while negotiations were taking place the allied forces would occupy the towns of Cordova, Orizaba and Tehuacan, while the fourth article stipulated that if the talks broke down they would withdraw below the lines of fortification on the road from Vera Cruz. If and when the allies withdrew, their sick and wounded would be cared for by the Mexicans. The final article stated that as soon as the allies began their march to Cordova, Orizaba and Tehuacan the Mexican flag would be raised again in the forts of Vera Cruz and St. Jean d'Ulloa. ${ }^{50}$

While Prim, Wyke and Jurien all professed to be pleased with what they had done, their reasons for this were to reveal the fundamental difference between the intentions of the French representatives and those of their colleagues. Prim defended his decision to treat with the Mexican government on the grounds that the govemment said time was needed to convince the majority of the nation that the allies had not come to threaten the independence or sovereignty of the country, and to dispel the belief that the French had come to impose a monarchy and the Spanish to re-establish their former domination. If the allies gave them time to influence the opinions of the people, the government would guarantee to do all it could to meet its obligations. They also claimed they had the wherewithal to establish a firm foundation for a stable government, and as this was one of the aims of the expedition Prim said he and his colleagues had agreed that they did not

50 Preliminary Convention of Soledad. A.D., Vol. 7, 1862, pp. 386-387. 
have the right to reject the government by supporting an opposition party. Any other action he believed would be unjust as well as impolitic as it was evident to those there in touch with the situation that the Reactionary Party no longer existed, because in two months they had seen no evidence of its presence.

He commented further that the French, who had hoped it would be easy to establish a monarchy, and who believed the monarchical element was strong in Mexico, were misled and now recognised their error. Prim claimed they now realised that it was not the intention of their governments to favour any person or party over another or to violate the independence, sovereignty and integrity of Mexico, and this was why they had treated with the government. ${ }^{51}$ Prim concluded his report by assuring Collantes that it would be only in the case of absolute necessity that he would resort to the use of arms, because he wished to avoid engaging the Spanish Government in an exercise requiring considerable resources, given the current state of affairs in Europe. He added:

Je crois en conscience que la tournure que nous avons donnée à cette question mérite d'être approuvée par le gouvernement de Sa Majesté. Nous avons été modérés et humains, et s'il arrive un jour où, convaincus de l'inefficacité des moyens pacifiques, nous aurons à recourir à la force, nous prouverons au monde entier que la modération et les sentiments d'humanité ne seront pas incompatibles avec ce que la valeur et le zèle pour l'honneur de notre patrie exigent de nous comme Espagnols et comme soldats. ${ }^{52}$

Wyke wrote in similar vein to Russell, expressing faith in the combination of Juarez and Doblado to redeem the country from anarchy. Mazade, in contrast, later asked what purpose could be served by negotiating with a power which had violated its obligations a hundred times already. Signing the Preliminaries had conferred a legitimacy on the Government that previously all three governments had refused to recognise, he said. All the Mexicans who wanted to help establish a more stable government would be discouraged by this, and to imagine that a solution could be achieved by peaceful means was chimerical, as was the thought that the Government would be intimidated by the allies. Having reduced the allies momentarily to inaction

\footnotetext{
51 Prim to Collantes, 20 February 1862. Ibid., pp. 382-386, and Procès-verbal of the twelfth conference of the Plenipotentiaries and Commanders of the allied Powers, 19 February 1862. Ibid., pp. 396-397.

${ }^{52}$ Prim to Collantes, 20 February 1862. Ibid., p. 386.
} 
Juarez had only entrenched himself in power and increased the violence against any opposition, Mazade claimed. ${ }^{53}$

Jurien was also pleased with the signing of the preliminaries, but for very different reasons from those of his colleagues. One of the reasons was that history had shown how precarious the existence of governments was in Mexico, and if another revolution occurred they would be released from the Convention, which seems to show that all along he had been playing a political game with his colleagues. He wrote to ChasseloupLaubat congratulating himself for the turn he expected events to take as a result of the negotiations. The Mexican government was mistaken, he said, if they thought it was in their interests to draw out the negotiations, because it was really the allies who would profit from it. Access to the interior of the country had been opened up, and having to move back below the designated points if talks broke down was not really a disadvantage, because if they moved forward of their own volition they would be doing so before they had assured means of transport. Under these new conditions, Jurien said, Mexico could not pose any obstacle to their advance, and if they had to withdraw they could recapture the advanced positions in eight days. ${ }^{54}$

Jurien had no anxiety about what he was doing, believing that the influence of France in Mexico was immense, and he commented to Chasseloup-Laubat that "the Emperor, protector of nationalities in Europe, need have only one concern in Mexico and that was that his intentions might be misunderstood". 55 He later wrote that he was satisfied with the present situation, and he was pleased that it provided the opportunity to separate the three armies. He assured the Minister that regardless of the difficulties he had encountered their time had not been wasted as they were infinitely further advanced than he would have dared to hope a month earlier. Until then, he said, he had never exaggerated his anxieties, and was not exaggerating his present hopes. ${ }^{56} \mathrm{He}$ mentioned

\footnotetext{
${ }^{53}$ Charles de Mazade, "L'Expédition du Mexique", R.D.M., Vol. 39, 15 May 1862, p. 500.

54 Jurien to Chasseloup Laubat, 22 February 1862. AN: BB 499.

55 Jurien to Chasseloup Laubat, 5 March 1862 . Ibid.

56 Jurien to Chasseloup Laubat, 22 February 1862. Ibid.
} 
that although the Preliminaries had not yet been ratified by Juarez, he was going to begin his advance with the French troops, his first step in separating the French from their allies. This was to result in further dissension between the French and their allies and contribute ultimately to the breakdown of the tri-partite Convention.

It was at this time that Jurien heard of the imminent arrival of General de Lorencez and the additional troops and he was surprised and concerned that his politics of conciliation might be repudiated by their arrival. He also reacted angrily to the news that he was to lose some of his powers and no longer be in command of the expeditionary forces. From a practical point of view it was logical that Lorencez, should be given control of the military operations which were now to be concentrated inland - hardly a role for an Admiral of the Navy - but Jurien was told he still had command of the political, maritime and commercial aspects of the campaign. His self esteem, however, was dealt a severe blow by this change, as can be seen in his response to Thouvenel:

De tous mes honneurs, il ne me reste que la moitié d'un pouvoir Diplomatique. Mais je suis vice-Amiral!57 C'est bon pour moi. Est-ce aussi bon pour vous? Here is the question. [sic]

J'écris une longue lettre très sincère à l'Empereur; mais elle arrivera au mois d'avril et pendant deux mois, on aura peut-être pesté contre moi parceque je n'aime pas les jouteurs, même quand ils gagnent. Les honnêtes gens s'abstiennent d'aller à la roulette.

Je vois bien pourquoi vous êtes revenu sur votre première dépêche qui m'investissait de la plénitude des pouvoirs diplomatiques. Ma dépêche du 30 décembre vous a fait craindre que je fusse dupe du général Prim. Je vous garantissais cependant le contraire. Tous ces gens-là avec leurs roueries ne m'ont conduit que jusqu' où je voulais aller.

Vous voulez que j'aie confiance en moi. Soyez satisfait. Je suis parfaitement convaincu d'avoir raison et d'avoir toujours raison. ${ }^{58}$

Despite this setback, and the pending arrival of Lorencez, he continued to justify his actions and prepare for future action in line with his view of how the campaign should be conducted.

\footnotetext{
57 Jurien was promoted from rear-Admiral to vice-Admiral in January 1862, before advice reached Paris of the proclamation to the Mexicans and of the negotiations with Juarez.

58 Jurien to Thouvenel (Personal), 2 March 1862. AMAE: PA.AP 233 Thouvenel, Vol 10.
} 
Regardless of his feelings about the change in his command, Jurien assured Thouvenel his relations with Lorencez would be established on the best foundation. He would continue to work happily towards his goal, but if he was withdrawn from his command he would "return cheerily aboard his ship" and not be angry because he knew that Thouvenel could not possibly know or understand the real situation in Mexico. In this letter, and in others, to Thouvenel, there are times when Jurien sounds almost a little mad as he justified his actions and defended his abilities, and perhaps this contributed to the concern in Paris over his handling of the situation in Mexico. He wrote that while they might lack confidence in him, "a poor makeshift diplomat", he knew it would not be permissible for him to call them "men of little faith" in return. If he was recalled, he believed that no matter what the future held for Mexico he would have represented the only ideas that could possibly triumph, and they were the moderate ideas. But he concluded with a comment which revealed again some insecurity and a longing for more immediate feedback. He thought that perhaps after all God was on his side because he was bound to succeed in his task:

\begin{abstract}
Ah! Si Vera Cruz n'était pas à deux milles lieues de Paris, que je serais donc tranquille! Mais ici, il faut, comme vous me l'avez très bien dit, que j'aie autant de confiance en moi que vous voulez bien en avoir vous-même. Or, c'est là le point difficile. La suffisance m'a toujours manqué. S'il n'y avait pas un Dieu pour les bonnes gens, je ne réussirais pas. Je réussis, donc, il y a un Dieu. ${ }^{59}$
\end{abstract}

Whatever Jurien's ideas, they did not include the possibility of negotiating further with the Juarez Government, and perhaps for good reason. On learning of the arrival of General Almonte, Padre Miranda and other Mexican exiles with Lorencez, the government had declared to the allied Plenipotentiaries that they would punish any such dissidents who had come to act against the legal government, and demanded that the allies refuse to offer them any support or protection. The government also reiterated that anyone assisting the allies would be punished. Both Prim and Wyke agreed with this ultimatum about not protecting the exiles and requested Jurien and Saligny to agree also, being convinced that there was nobody else in the country capable of establishing a stable

59Jurien to Thouvenel (Personal), 14 March 1862. AMAE: PA-AP 233 Thouvenel, Vol. 10. 
government and that there was definitely no evidence of support for a monarchy. Jurien, as has been seen, had acknowledged this latter point also, but the severity of the actions of the Juarez government had encouraged him to persist in the pursuit of his goal. All the evidence seemed to support Prim's views, yet Jurien was prepared to act in contradiction to his own observations and those of others, in blind obedience to what he believed the Emperor wanted. Prim commented to Collantes that the French language newspapers had openly stated that the mission of the French army was to install Maximilian on the throne, and this was likely to cause problems not only between the French and Mexican governments but also among the allied governments. He added that the refusal of Jurien and Saligny to agree to the ultimatum issued by Juarez and Doblado was likely to lead to a rupture in relations among the allied representatives. 60

Jurien in fact saw this ultimatum as the opportunity to reach agreement on the form that the intervention should take, believing it gave the allies the chance to broach again the idea of a general amnesty and to reiterate their refusal to sanction the violent methods proposed by Juarez. ${ }^{61}$ He therefore decided to issue his own ultimatum to Doblado and Juarez through their intermediary, Colonel Cautelenne. He declared that if they did not grant an unqualified general amnesty to Almonte and the other Mexican emigrants he would fulfil the conditions of Soledad by withdrawing his troops below the fortifications of Chiquihuite, and twenty four hours later begin hostilities against the Mexican government. His decision to do this was based firstly on his earlier instructions that he was not to refuse his support to any party that appeared to have the support of the people and the chance of successfully forming a government, and secondly on the premise that because the Emperor sanctioned the journey of Almonte to Mexico, it was his Party that he wished to support to form a government. 62 Jurien did not have any evidence to support this assumption as he had not at this point actually met up with Lorencez and the Mexican contingent, so he was acting entirely on his own initiative. He also had no idea

\footnotetext{
${ }^{60}$ Prim to Collantes, 17 March 1862. A.D., Vol. 7, pp. 407-409.

61 Jurien to Prim, 13 March 1862. AN: BB 499.

${ }^{62}$ Reported by Jurien to Chasseloup-Laubat, 17 March 1862. AN: BB 799.
} 
whether the majority of the people were prepared to support Almonte, and the Emperor and Thouvenel had intimated that they had no preference for a particular party. Always they had stressed supporting the party that came to them with some chance of success in forming a government.

Having issued his ultimatum that would result in the opening of hostilities between France and Mexico, Jurien then proceeded to carry out his plan to separate from his allies. He wrote to Prim reminding him that he had always agreed with him that it was important not to identify with a minority party, but he had told Prim often that he would always advise any party that establishing a monarchy was the only way to end the dissensions dividing the country. He thought conciliation was the only way to achieve this so he had signed the Preliminaries of Soledad believing the respite provided by it would give them time to influence the people, without pressuring them, and "to prepare them for the solution that to me seems the most favourable". 63 He congratulated Prim on the fact that his actions had at least reassured Mexico that they had not come to restore an unwanted domination of the country, but he lamented the fact that the expedition had taken on a largely Spanish flavour because of the greater number of their troops, and because of the preponderant role Prim had played in the negotiations. Nevertheless he respected Prim, saying that if he had been only a soldier and not a politician also, he might have dragged them into a war which would have had the whole country against them.

The most telling part of this letter to Prim, however, is contained in the following statements which indicate quite clearly that Jurien was acting on his own initiative. While other historians have acknowledged the part played by the Plenipotentiaries in providing misleading information, and making decisions that were criticised by their government, they have not really focused on statements such as this by Jurien despite their being in the published diplomatic correspondence. Jurien wrote:

63 Jurien to Prim, 20 March 1862. A.D., Vol. 7, 1862, pp. 414-415. 
Je ne mets pas en doute, quoiqu'on ne m'en ait rien dit, que l'Empereur, lorsqu'il s'est décidé à envoyer ici une nouvelle armée et un général pour commander ses troupes, n'a pu avoir en vue que de dégager l'action de la France et de lui réserver l'entière liberté de ses décisions.

He then quite candidly accepted responsibility for his decisions as he told Prim he believed the importance of his own command meant he could no longer subordinate his political views to any other Plenipotentiary, so while he respected Prim and believed they would continue to work in agreement, he intended to separate his army from that of the Spanish and English:

Je suis décidé, en un mot, à poursuivre, à mes risques et perils, le but que je veux atteindre. Je désire profiter, pour y arriver, de la sympathie très réelle qu'on paraît éprouver ici pour la France. Par conséquence, sans renier nos alliés, sans séparer le moins du monde notre cause de la leur, je tiens à ce qu'il soit bien établi, aux yeux de tous, que notre expédition est une expédition française, et qu'elle n'est sous les ordres de personne. ${ }^{64}$

What Jurien had failed to understand was that the alliance with Spain and England, intended to be affirmed by this joint venture, was as important to the Emperor as the constitution of a stable government in Mexico. Prim, however, did, so when he replied to Jurien he could not help but express his disbelief and disappointment that the Emperor might have issued instructions that showed an intention to break the Convention of London:

Si vous avez reçus des ordres de votre gouvernement à cet égard, j'avoue que je ne reconnais plus la sagesse, la justice, ni la grandeur de la politique impériale, comme je ne reconnais pas non plus le haut esprit de conciliation de l'Empereur envers l'Angleterre et l'Espagne. ${ }^{65}$

In Prim's opinion, what Jurien was about to do would not only prove a disaster but would severely damage the friendly relations of England and Spain with France, and, he said, "nobody would be more upset than I who have the greatest respect and admiration for the Emperor as well as a love of France and the French people." However, seeing Jurien was set on his plan of action, Prim realised that all that could be done was to meet and formalise the rupture of the accord in a final statement.

${ }^{64}$ Ibid., pp. $415-416$.

${ }^{65}$ Prim to Jurien, 23 March 1862. A.D., Vol. 7, 1862, pp. 419-420. 
These views of Prim had recently been expressed in letters to Napoleon and to the French Ambassadors in Madrid and Vienna, in which he justified his own actions in negotiating with the Juarez Government instead of lending support to the more extreme factions. To Barrot in Madrid he admitted that there was a small portion of the population in favour of a monarchy, but none of them would do anything to bring the idea to fruition. If a monarchy was imposed some would fight it while the majority would accept it complacently, but as soon as the support of foreign soldiers was withdrawn the throne would collapse. He continued:

Je ne doute pas qu'il soît loin de la pensée de l'Empereur d'imposer au pays ce qu'il ne veut pas; de semblables vues ne sauraient appartenir à un souverain qui, comme Sa Majesté Impériale, doit son immense pouvoir et la grandeur de sa règne, à la volonté de sept millions de Français. Mais ce n'est pas consulter un pays que de faire comme se le proposent les conservateurs qui veulent créer une monarchie en ne consultant que les hommes considérables de leur propre parti et les gens riches, tandis que le reste de la nation à leurs yeux, "ce sont des anarchistes et des demagogues, ou une populace grossière et ignorante, dont ce n'est pas la peine de demander l'avis." 66

Persuasive as Prim's arguments may have been, Barrot's comments in reply reflected the core of the criticism both the Emperor and his government had of the actions taken thus far in Mexico - the recognition of the government that all three of the allied governments had condemned and refused to treat with further. Barrot said he had never anticipated the representatives obtaining financial retribution because of the state of the country, but he believed their presence would encourage the majority of people to support the allies to form a stable government. He appreciated it would be difficult to get unity among people so widely dispersed, but in contrast to Prim he believed it was useless to treat with Juarez who had broken all previous agreements. The conservatives, he thought, would now lose faith in the allies, which made the march to Mexico City essential. ${ }^{67}$ Barrot at the same time had the greatest esteem for Prim and firmly believed that he was entirely concerned with developing and maintaining good relations with France.

\footnotetext{
66 Prim to Barrot, 8 March 1862. AMAE: PA-AP 233 Thouvenel, Vol. 10.

${ }^{67}$ Bartot to Prim, 28 April 1862. AMAE: PA-AP 009 Barrot, Vol 16.
} 
Prim's letter to the Emperor was in response to one from Napoleon announcing that he was sending more troops with Lorencez, and in which he spoke of his desire for the alliance between France and Spain to be strengthened by this joint campaign in Mexico. ${ }^{68}$ Prim remarked that he too wished to cement the Franco-Spanish alliance but he had hoped it would be in a more glorious campaign than this Mexican one could ever be. He still believed that they would be able to obtain justice from the Juarez government in which case there would be no need to fight. He then proceeded to inform the Emperor of his opinion of the situation in Mexico and the futility of trying to establish a monarchy in a country that had no real experience of such a system and which was so strongly influenced by the republican governments around it, particularly to the north. ${ }^{69}$ There does not appear to be a reply to this from Napoleon.

Wyke also tried to persuade Jurien against his decision to withdraw his troops to prepare for hostilities against Mexico, and said that supporting Almonte, the head of the Party of Marquez which was at war with Juarez, was showing partiality to an enemy of the government with whom they were negotiating. ${ }^{70}$ Wyke had already learned from Dunlop that although Saligny had told him Almonte was to advance under the protection of the French, on orders of the Emperor, Lorencez had denied that this was so and had offered to send Almonte and the other Mexicans back to Vera Cruz. ${ }^{71}$ Wyke reported Jurien had replied that it had been without his consent and through a regrettable misunderstanding that the Mexicans had been placed under the protection of the French flag. He agreed with Wyke that it was not appropriate to accept the help of another party whilst negotiating with a government, and said if it had been up to him he would have invited them to return to Vera Cruz. Jurien had decided instead to ensure they came only as far as Cordova and remained there. He then justified his decision to draw his troops back before the conference at Orizaba on the grounds that if the talks broke down they would have been stranded in the unhealthy zone at the beginning of the hot season,

\footnotetext{
${ }^{68}$ Napoleon to Prim, 24 January 1862. A.D., Vol. 7, 1862, pp. 446-447.

${ }^{69}$ Prim to Napoleon, 17 March 1862. Ibid., pp. 447-450.

${ }^{70}$ Wyke to Jurien, 27 March 1862. State Papers Vol 53, 1862-1863, pp. 505-507.

${ }^{71}$ Wyke to Russell, 27 March 1862. Ibid., p. 502.
} 
exposing their troops to disease and death. Wyke accepted Jurien's explanations and pronounced him exonerated of any blame regarding the protection afforded the Mexican exiles, but suggested it would only compromise their cause if he did not send them back to Vera Cruz.

Saligny to this point had managed to keep himself relatively in the background by absenting himself from a number of the allied conferences, but he was suddenly to reveal that he had objected to the combined actions to which he had given silent assent, or to which he had actually appended his signature. Ollivier added a none too flattering description of Saligny to the universally negative remarks that have already been seen. He described him as:

violent, passioné, cassant, serviteur d'une cause, non observateur d'une situation, décidé à ne rien entendre, à ne rien voir de ce qui contrariait son parti pris systématique. ${ }^{72}$

Despite comments such as this, it is still difficult to understand what motivated Saligny's behaviour, and just what he hoped to gain. The only indication he gave of his motivation was in his assertions that he was doing what the Emperor wanted. Perhaps he was looking for an opportunity to do something that would gain praise and some reward from the Emperor after such a long period without a diplomatic post. Almonte later suggested to the Emperor perhaps it was time to make Saligny a senator, something he claimed the Emperor had promised, but which Napoleon denied. All this of course seems to call into question the wisdom of employing someone like Saligny at all, and I can only refer again to comments made by Roeder in relation to the "partisan and irresponsible diplomat [s] that flourished so freely in Mexico". ${ }^{73}$ Perhaps the fact it had not been traditionally an important post, and the task initially was not considered a difficult one, were the factors that caused the Foreign Affairs department to use the readily available Saligny.

Saligny was highly indignant when he heard a report that Lorencez intended sending Almonte and his friends back to Vera Cruz, and possibly even to France, and he

72Émile Ollivier, L'Empire Libéral, Vol. 5, p. 249.

${ }^{73}$ Ralph Roeder, Juarez and His Mexico, p. 276. 
wrote to Jurien that he could not believe he would sanction such a move which he, Saligny, believed would be the greatest blow to the politics of the Emperor. If they had to wait in Vera Cruz they would be exposed to the vomito, so he would not hesitate to bring them inland again, convinced that he was obeying the wishes of the Emperor. ${ }^{74}$ He then told Jurien that his firm opinion was that they could no more treat with Doblado than Juarez, as he was the instigator of the outrages committed against their nationals over the previous three months - outrages that nobody else seemed to have heard about. But while he emphasised the need to protect their nationals, he strangely proceeded to warn Jurien against all the Frenchmen in the country:

Je vous supplie mon cher Amiral, de tenir en grande méfiance tous les français sans aucune exception, de Cordova, Orizaba etc. Ce sont tous d'affreuses canailles, rouge sang de bœuf. Il n'en ait presque pas qui n'aient été obligés de quitter leur Pays pour des raisons peu favorables; et tout naturellement ils détestent la France et son Gouvernement et sont inféodés - je crois corps et âme - s'ils avaient une âme - à cette bande de malfaiteurs qu'on appelle le Gouvernement libéral. ${ }^{75}$

It will be seen that the French nationals' opinions of Saligny were little better than his of them, although perhaps they had much more justification for their views than did he. But it seemed Saligny's determination not to deal with the Juarez government knew no bounds, because he continued to plead protection of French nationals despite the above comments.

The behaviour of Saligny was raised in the meeting which was held on 9 April to discuss the intention of the French to declare hostilities against Mexico and separate from their allies, and revealed just how unscrupulous he was. Firstly, though, Jurien justified the decision he had already taken to act more energetically, saying it was in accordance with the intentions of his government, as expressed in a recently received despatch from Thouvenel. This despatch was referred to above when discussing Napoleon's reaction to the initial proclamation, but it was not received until after Jurien had made his own

\footnotetext{
${ }^{74}$ Saligny to Jurien, 29 March 1862. AMAE: PA-AP 233 Thouvenel, Vol. 10.

75 Saligny to Jurien, 30 March 1862. AMAE: PA-AP 233 Thouvenel, Vol. 10
} 
decision to act. Thouvenel had written that if Spain and England refused to support the French claims,

M. l'Amiral Jurien et M. de Saligny, en ayant soin toutefois de se rendre compte exact des nécessités de notre situation militaire et de l'état général des choses au Mexique, seraient autorisés à laisser leurs collègues traiter séparément et à poursuivre seul la réparation due à la France. La gravité même de cette résolution indique qu'elle ne devrait être prise qu'à la dernière extrémité et après calcul fait des chances du succès de notre action isolée. ${ }^{76}$

Although these instructions were later moderated, and Saligny advised to be circumspect in the claims he pressed, Jurien saw here support for the decision he had already taken to separate his troops and his actions from those of his allies, despite the cautionary direction that such action should only be taken as a last resort.

Wyke suggested that despite Jurien's instructions they had all agreed to treat with the Juarez government, so on that basis the French decision to offer protection to Almonte showed partisanship on their part and therefore was not in accordance with the Convention of London. Jurien responded that the protection offered was only that of the French flag and such protection of an exile in no way constituted interference in the internal affairs of the country. Prim disagreed saying that Almonte and the others had arrived with hostile intentions against the established government with whom the allies were in negotiations. Jurien replied that this was not the case as Almonte, like everyone in Europe believed they were at war in Mexico and he had come to conciliate with the different factions, and to reassure them of the kindly views of Europe towards them. He then suggested that the very reasons that Prim advanced to support the impossibility of a monarchy were the same reasons that justified such a dramatic change in the institutions of Mexico, because none of the previous republican regimes had been able to halt the continual revolutions that had led the country to the deplorable state in which it found itself. 77

\footnotetext{
${ }^{76}$ Thouvenel to Jurien, 21 February 1862 (r. 3 April). AMAE: CP Mexique, Vol. 58.

${ }^{77}$ Proceedings of the Conference held at Orizaba 9 April 1862 between the representatives of the Allied Powers. A.D., Vol. 7, 1862, pp. 421-433.
} 
Wyke and Prim continued, however, to maintain they had made the right decision to negotiate with the government, and that representatives of the Mexican government had agreed to withdraw the tax of two per cent on foreign capital, to retract the decree interrupting communications between Vera Cruz and the interior, and made known their intention to satisfy all the claims of the allied governments. If these promises were not kept then it would be time to declare war, not now for "futile motives which could not be justified before the great tribunal of the civilised world". Prim asked why the French representatives would not wait six more days until the proposed conference with the Mexicans. Saligny said his reasons were based on the numerous complaints he continued to receive, from both French and Spanish nationals, against the Mexican Government. Wyke was astounded that, if such claims were true, he had not received any news of them. Saligny's response was that French subjects were not likely to take their complaints to the British legation.

This sudden claim, in contrast to what he had already said about the French in Mexico, precipitated a questioning of Saligny's behaviour since the initial proclamation to the Mexican people. He was asked whether it were true that he had said the Preliminaries were not worth the paper they had been written on. Saligny replied he had never had the least confidence in anything emanating from the Mexican government whether it was the Preliminaries or any other engagement. When asked by Dunlop why he had signed them, and then having done so why he did not feel formally bound by them, Saligny said he did not have to give his reasons for signing them but he did not feel bound by them when the Mexican government had violated them in a thousand ways. Saligny had been heard to say shortly after the signing of the Preliminaries of Soledad that he had not agreed with either this document or the original proclamation. ${ }^{78}$ An anonymous writer to Thouvenel justified Saligny's behaviour at the time with the argument that he had not wanted to compromise the situation by voicing his opposition, and he had in fact prevented a further useless convention being signed with the Juarez government. ${ }^{79}$

\footnotetext{
${ }^{78}$ French Commandant Raze in Vera Cruz to Jurien, 26 February 1862. AN: BB 41813.

${ }^{79}$ Unsigned letter to Thouvenel dated 4 March 1862. AMAE: PA-AP 233 Thouvenel, Vol. 10.
} 
Resuming the purpose of the conference, which was to discuss whether or not the French were going to withdraw their support of Almonte and continue to act with their allies, Jurien and Saligny said they could not support the government of Juarez which had submitted its people to a reign of terror and continued to exile or execute some of the country's more reasonable leaders. Wyke countered this with the claim that the majority of the people supported the government and that it would be difficult to find supporters of a monarchy. Jurien brushed aside the projects relative to the candidature of Maximilian saying it was not a question of a monarchy at that point as this could only be raised after considering the urgent need of the country to experience a moral and respected government which would not stifle the free expression of the wishes of the intelligent and moderate section of the nation. He continued, that this majority existed but it was possible it had not shown itself because it had reason to believe the allied representatives were hostile to it, and he concluded:

Ce parti, qui attend notre appui ... nous le trouverons partout le jour où il sera libre de déclarer quels sont ses véritables sentiments. Le gouvernement de l'Empereur, bien informé sur ce point, désire marcher en conséquence sur Mexico, et telle est la détermination du commissaire français. ${ }^{80}$

Yet the evidence before his eyes seemed to refute what he was saying.

The result of this conference was that the French were determined to act forcefully and alone, causing the campaign to enter a new phase. As the French refused to participate in the proposed Orizaba Conference, it was agreed they had precipitated a rupture in relations with their allies, and the Spanish and English had no alternative but to re-embark their forces and leave Mexico. ${ }^{81}$ The same day Saligny and Jurien wrote to Doblado, the Foreign Minister, saying that the harassment of their nationals by the Mexican government since the signing of Soledad, and the violent measures adopted to stifle the expression of the wishes of the people, meant the French could no longer negotiate with them. They continued:

\footnotetext{
${ }^{80}$ Proceedings of the Conference held at Orizaba 9 April 1862 between the representatives of the Allied Powers. A.D., Vol. 7, 1862, pp. 421-433.

${ }^{81}$ Ibid.
} 
Les soussignés demeurent convaincus que s'ils pérséveraient dans la voie où le désir d'éviter l'effusion du sang les a engagés, ils s'exposeraient à méconnaître les intentions de leur gouvernement et à devenir involontairement les complices de cette compression morale sous laquelle gémit aujourd'hui la grande majorité du peuple mexicain. ${ }^{82}$

They concluded by announcing that they would withdraw beyond the fortified positions of Chiquihuite and when the last Spanish troops had re-embarked they would take the action they believed necessary.

Doblado replied immediately, questioning why the French representatives had recognised his government as the legitimate administration by signing Soledad, if now they claimed that administration was only maintained by an oppressive minority. Further, he disclaimed any knowledge of harassment or maltreatment of French nationals since Soledad, as none of the local authorities had reported any notable facts in this respect. This denial probably means nothing in itself, but Doblado added that as the French had both the liberty and the opportunity to address reclamations to the government for any such violation, their silence to this point would lead them to believe that no act worthy of reclamation had been committed. This assertion is supported by the reactions of Wyke and Prim in the allied conference and by the fact that Saligny was the only one who claimed knowledge of any violations. Doblado concluded that they had been prepared to exhaust every possible means of negotiation, but if the French refused to do this then, without being the aggressor itself, Mexico would defend to the last its independence and right to instigate reform. ${ }^{83}$ He said as much to Wyke and Prim when he replied to the combined note from the allied commissioners, and added that his government was now prepared to negotiate with England and Spain to satisfy all their reclamations and to give them guarantees for the future.

These questionable claims by Saligny served to add weight to the suggestion that the French were looking for a pretext to suspend the accord with their allies, as did Jurien's comments to his Minister about having been determined to find an excuse to do

\footnotetext{
${ }^{82}$ Saligny and Jurien to Doblado, 9 April 1862. A.D., Vol. 7, 1862, p.435.
}

${ }^{83}$ Doblado to Saligny and Jurien, 11 April 1862 . Ibid., pp. 435-436. 
this. He explained to Chasseloup-Laubat that if he and Saligny had agreed to wait until the conference with the Mexicans on 15 April, one of two things might have happened. The government might have agreed without reservation to all their demands, as seemed likely from all reports, giving them no pretext to break with them. Or, alternatively, "the well established connivance between our enemies and our allies" would have caused the negotiations to be prolonged so that the retrograde movement imposed by Soledad, if talks broke down, would have to be accomplished in the unhealthy season. If either case had arisen, Jurien said, it would have been necessary to find another incident to justify a break with their allies which had become more than ever necessary. Fortunately such an incident had presented itself when the Mexican government refused to include Almonte and his companions in the general amnesty demanded by Jurien. As they were under the umbrella of French protection and had made no secret of their intention to overthrow the government, Jurien could now openly declare war. ${ }^{84}$

It was in this report to Chasseloup-Laubat that Jurien made it quite clear that he took responsibility for having given his own interpretation to the Convention of London. He said:

Je n'en demande pas moins que toute la responsabilité n'en retombe que sur moi. J'ai dû à mes collègues et je l'ai fait constater au procès verbal que si le gouvernement de l'Empereur avait conclu la Convention de Londres, c'étaient ses plénipotentiaires qui, à leurs risques et périls, l'avaient interprétée. ${ }^{85}$

But while he anticipated the repercussions in Europe he believed events justified his conduct since his arrival at Vera Cruz, and he was the only one who could see the venture successfully concluded. He said he was gaining the respect of the Mexican people, who were getting to know him now he was no longer in the shadow of Prim's strong personality, and he was certain they would believe that he was speaking for the Emperor when he said the French would not restore former abuses or impose an unwanted Prince.

\footnotetext{
${ }^{84}$ Jurien to Chasseloup-Laubat, 11 April 1862. AN: BB $^{4} 799$.

${ }^{85}$ Ibid.
} 
The situation for the French government, however, was complicated still further by the mutual criticisms that reached Paris from Saligny and Jurien. Saligny had written to Paris condemning Jurien's behaviour, and Jurien was not to know that his removal from Mexico had been ordered when the Emperor learned of the decision to negotiate with Juarez. Saligny had probably been exonerated of blame for this decision by his statement that he did not agree with it, and by a letter to his friend General Rollin, the AdjutantGeneral of the palace, condemning Jurien. Saligny had blamed Jurien for the fact that their troops had been too poorly equipped to move inland immediately upon their arrival in Mexico, and he had concluded:

L'amiral, je l'avouerai, m'afflige et m'épouvante par ses irrésolutions, par son aveugle foi en nos adversaires, par sa confiance en lui-même et en sa fortune; confiance que je voudrais voir partagée par ses officiers et ses soldats.

La mienne est tout entière dans l'Empereur, dans l'Empereur seul, dont la sollicitude saura, quoi qu'il arrive, aviser à toutes les mesures nécessaires pour sauvegarder l'honneur de notre drapeau. 86

Jurien in turn denounced the behaviour and attitude of Saligny, which he believed would cause the war to degenerate into a personal quarrel between Saligny and the Mexican nation. Although his own name, he wrote to Thouvenel, might discourage the "exalted conservatives", that of Saligny frightened all the Liberal Party, therefore Thouvenel needed to decide which of the two of them he intended to support. He then told him that his naval colleague, Devarenne, was on his way to Paris to brief both the Ministers and the Emperor on the reality of the situation in Mexico, the problems caused by Saligny, and his own assessment of how the campaign should be conducted ${ }^{87}$ Although the Emperor listened sympathetically to Devarenne when he reached Paris in May, he did not seem to be influenced by Jurien's arguments about Saligny, and it was Saligny who was to be trusted, for a further twelve months, in preference to Napoleon's commanders. Besides, Jurien's return to his squadron had already been ordered.

\footnotetext{
86 Saligny to General Rollin, 8 February 1862. AN: 400AP 62 Archives napoléon.

87Jurien to Thouvenel (Personal), 17 April 1862. AMAE: PA-AP 233 Thouvenel, Vol, 10.
} 
The suspension of the Convention of London by their plenipotentiaries in Mexico was to cause consternation to the three governments but it was not only the behaviour of the French representatives that should be questioned. For instance, it was Wyke who called most strongly for decided action to be taken against Mexico, yet once he had set the wheels in motion he began to negotiate an agreement to settle British claims, on the basis that there was now a more reasonable person, Doblado, who had control of the government. However, by that time the Convention had been signed and joint action was planned. After the breakdown Wyke insisted that the regime headed by Doblado was different to that previously headed by Juarez. He wrote to Russell that the French continued to confuse

the existing government under the absolute direction of Doblado, with that formerly existing before his nomination as Prime Minister, simply because Juarez still remains President.

Now the two periods are quite distinct, and it is necessary that this should be clearly understood. . . . Juarez still remains President, but now he is a cypher, whereas formerly he was mischievous from allowing others to do harm unchecked. As his name is discredited the French constantly speak of the present Government as "le gouvernement Juarez" thus leading those not accurately acquainted with the subject to suppose that it is the same government which by its acts brought about the intervention of the three Powers. ${ }^{88}$

Wyke seems to have been the only one of the Plenipotentiaries to have tried to convince his government that the justification for negotiating with the Mexican government was because it was then a different government. It is also possible that Wyke was justifying their decision to negotiate instead of issuing an ultimatum in response to Russell's criticism of the terms of the proclamation made in January. Be that as it may, there is an underlying issue to consider, of whether or not the representatives were correct in their judgement that the best course to follow was negotiation. There is much evidence to suggest that Wyke and Prim were more astute in their assessment of the situation, and of the people in Mexico, than were Saligny and Jurien, but the decision of their governments had been based on the premise that the time for negotiation had passed and that firm action was required. And that premise had been founded largely on

\footnotetext{
${ }^{88}$ Wyke to Russell (Private), 12 April 1862. PRO: PRO 30/22/74 Russell Papers.
} 
the information that had been sent to them over the previous months by Wyke and Saligny.

Schlœsing later suggested to General Bazaine that if he investigated all the complaints made by Saligny against the Juarez government, he would find "some grossly exaggerated, others misrepresented, and that most of those that were accurate had been caused by the reactionary faction while being represented as being the responsibility of the constitutional party." 89 He also commented that when the governments had decided to intervene the French residents had hoped the intention was to affirm the legal regime of Juarez and "assure forever the pacification of the country". The supporters of Juarez had also been pleased to see France among the Powers, as they were only apprehensive about Spain's intentions. Everyone in Mexico, he said, was therefore surprised to find the French representatives refused to negotiate with Juarez and that France alone remained to make war against the Mexican government.

The questionable behaviour of the Spanish in the early stages has been examined and some issues raised relating to the motives of Prim, but as the intervention progressed it seems harder to criticise the reasoning behind his decisions or the reasonable manner in which he tried to argue with Jurien and Saligny. Whether Prim and Wyke were right or not, however, has become a rhetorical question in the study of the intervention in Mexico, for in the final analysis it was the behaviour of the French representatives that had the greatest impact on the campaign and on the credibility of Napoleon III. What makes it even more difficult to exonerate Napelaan of blame for the direction of events is the actions of the subsequent commanders of the expedition. Were they all motivated by private ambition? Or did they really believe Napoleon's intentions were other than what he wrote? Whether or not they were correct, however, can be determined only when the Mexican campaign is examined within the context of Napoleon's foreign policy as it will be below in Chapter 8 .

\footnotetext{
${ }^{89}$ Schlœsing to Bazaine, 14 October 1863. Paul Gaulot, L'Expédition du Mexique, p.426.
} 
The venture by this time had very definitely taken on a life of its own, and it was to be mid-May before the governments of England, France and Spain learned that their representatives had suspended the Convention of London, and that France was now committed to a military campaign alone. While the Plenipotentiaries were formalising their separation, their governments were only just responding to the news of the signing of the Preliminaries of Soledad, illustrating just how much the venture was beyond their control at such a distance. None of them had anticipated that the expedition they had prepared so hastily was destined to get so out of hand. And soon France's honour was to be engaged by an unexpected military defeat, which evoked considerable criticism by the Opposition. It was in the aftermath of this defeat, and on hearing the reports of Jurien's friend, Devarenne, and others that Napoleon realised that his intentions in Mexico had been misunderstood or misinterpreted by his representatives. He therefore made a further change in command and wrote a clear and unequivocal exposé of his intentions in Mexico in his instructions to General Forey, who replaced Lorencez. But still he did not anticipate a lengthy or difficult campaign. 


\section{Chapter $\mathbf{5}$}

\section{Our Botrour exgaged}

The reaction of the three Governments to the initial advice of the Preliminaries of Soledad was one of anger and disbelief that their representatives were continuing to negotiate with the discredited Juarez government. None of them could accept the idea of the Mexican flag being allowed to be raised beside their own in Vera Cruz and St. Jean d'Ulloa, which they had occupied, nor the stipulation that the allied troops would withdraw from their advanced positions if talks broke down. The preliminaries also gave the government a legitimacy it did not deserve. But when their envoys' reports reached Europe the Spanish and English governments decided to approve the actions of their representatives even though they would have preferred some of the articles of the Preliminaries were worded differently.

The Emperor was furious at the turn events had taken with Soledad, and his initial reaction was to recall Jurien and publicly repudiate his actions. An article was placed in Le Moniteur criticising him, and a member of the Corps législatif wrote to Jurien that it seemed to have been authorised by the Emperor, who was not pleased with the results of the mission to Mexico City, "where, in his impatience he believed you had already arrived". It appeared, he said, that the Emperor had not been made aware of the practical difficulties they would encounter on their arrival, as far as transport and supplies were concerned. He was preoccupied with the need for their prompt arrival in the capital in the light of recent successes of the Federal armies in America, and the opposition that French politics might encounter from a pacified United States. Jurien was advised that regardless of his original instructions he should reach Mexico City as quickly as possible, "for in our country, people do not take into account the difficulties, they are only concerned with success". 1

\footnotetext{
${ }^{1}$ Member of Corps Législatif (signature indecipherable) to Jurien, 17 March 1862. AN: BB ${ }^{4} 1812$.
} 
Two days later Admiral La Roncière Le Noury wrote to tell Jurien that much of the outcry against him had been caused by letters written by Saligny or his friends, but he reassured him that he still had much support in Paris. There was a certain amount of jealousy in the departments of Foreign Affairs and War, however, about the powers that Jurien had, although the respective Ministers did not feel this way. He also reassured Jurien that in Marine and Colonies they had never varied in their support of him and insisted that as he had started the enterprise he should be allowed to finish it, rejecting suggestions that General Lorencez be named Plenipotentiary or that Saligny be put in control of everything. Their objections were based on the fact that they were too far away to judge the situation and things should be allowed to follow their course. He then reassured Jurien that now everyone was aware that they had been misled by the Mexican refugees about the sentiments of the people ("situation des esprits") in Mexico, and concluded:

Le Ministre vous est favorable, le Maréchal Randon et M. Thouvenel aussi. C'est au château que l'on s'est le plus agité, et c'était naturel en égard à la singularité de l'entreprise. ${ }^{2}$

The reason there was agitation in the Tuileries was because the Emperor was concerned that the recent victories of the Federal states over the Confederate states of America would result in a different future in the area than the previously anticipated victory of the Confederate states might have. Napoleon was obviously worried that the United States would object strongly, once they were at peace, to any lengthy role played by France, or any of the nations, in Mexico, and his angry reaction to the drawn out negotiations of the Plenipotentiaries reinforces the argument that he had no intention of remaining in Mexico any longer than was absolutely necessary.

He was determined to redeem as much as he could of his policy so it was decided, in spite of the protests of the Ministry of Marine and Colonies, that the command of the venture should be organised differently. Thouvenel wrote to Saligny advising him that he now would have responsibility for the political direction of the venture and that the

\footnotetext{
${ }^{2}$ La Roncière Le Noury to Jurien, 19 March 1862. AN: BB 4 1812. Marshal Randon was the Minister for War.
} 
Emperor was counting on his prudence as well as his "zeal" for the good of his service, while Lorencez would control all military operations and questions relating to the health and security of the troops. Saligny was told that he had to maintain the best relations with the general and under no circumstances was he to interfere in the military direction of the campaign. Significantly, Thouvenel reiterated the aims of the venture in the same terms that he and the Emperor had always expressed them:

Ce que nous demandons aux Mexicains, c'est avant tout le redressement de nos griefs et un Gouvernment qui nous donne des garantis pour l'avenir.

Quant à la forme et du personnel de ce Gouvernement, nous ne prétendons pas l'imposer. Ce qu'il doit ou peut être dépend absolument des circonstances locales et de l'appréciation des hommes sages et amis de leur pays, comme le Général Almonte par exemple. ${ }^{3}$

In dramatic contrast to the French, the Spanish and English governments changed their original views on the Preliminaries when the written reports of their Ministers were received. Thouvenel wrote to Barrot recognising the futility of trying to reverse what had happened and hoping that if the commanders did not get satisfaction from the Mexican government they would take decisive military action quickly. ${ }^{4}$ The Spanish government on the other hand decided that negotiating with the Juarez government would probably serve a useful purpose and war could still be declared if satisfaction was not received, which is precisely what Prim had said in his report. Collantes declared that Spain was determined that the three governments still work together and hoped this was possible even though France disapproved the Preliminaries. He admitted the Spanish government would have preferred that some of the articles were omitted or worded differently, but on the whole it was happy with Prim's behaviour. At the same time Collantes suggested to the French government that a new conference of the three Powers be convened to clarify the way in which the expedition should now be carried out. ${ }^{5}$

England decided to sanction the Preliminaries after reading them because the government's initial concern, the thought of the Mexican flag flying next to those of the

\footnotetext{
3Thouvenel to Saligny, 20 March 1862. AMAE: CP Mexique, Vol. 58.

${ }^{4}$ Thouvenel to Barrot, 1 April 1862. A.D. Vol. 9, 1863, p. 320.

${ }^{5}$ Collantes to Chargé d'Affaires in Paris, 18 April 1862. A.D., Vol. 7, 1862, pp. 404-407.
} 
allies, was dispelled when they realised the allies would still retain military occupation and possession of both ports. Russell told Wyke that the convention would also dispel the fear that the allies intended to interfere in the internal affairs of Mexico, "which, it must be admitted, was too much countenanced by the imprudent language held regarding the "regeneration of Mexico' " in their proclamation to the Mexicans in January.6 The fact that the allies would not have to withdraw as far as Vera Cruz if hostilities did break out, and that their sick would be cared for had also persuaded the British government to approve their attempt at further negotiation. While all the articles were not approved, the general spirit of it was in accord with British intentions. In the House of Commons the convention was discussed on 4 April and a spokesman for the government assured the members that this convention meant their differences with Mexico could be satisfied by "negotiation and pacific means" and it was hoped they would not have to resort to war.?

At this time the subject of a monarchy and the wishes of the people of Mexico was discussed again between the three governments because of reports that the French representatives in Mexico were pushing for its establishment. Muro, the Spanish chargé in Paris told Thouvenel that in the light of information from the Captain-General of Cuba, it would seem the Mexicans in Paris were mistaken in their belief there was a large Monarchical Party in Mexico that would declare itself on the arrival of the allies, for so far they had shown no sign of their existence. Thouvenel accepted that Muro's observation might be correct, but added:

sans arriver nécessairement à la monarchie, il y avait beaucoup de degrés à parcourir dans les formes de gouvernement et que l'on pouvait bien tâcher de pousser au Mexique à l'établissement d'un pouvoir plus solide et plus fort que celui qui existe aujourd'hui. ${ }^{8}$

In spite of comments such as this, suspicion of the intentions of the French in this respect were not to be allayed. The English particularly were convinced France wanted a monarchy, and while they thought it was probably the best solution for Mexico, they

\footnotetext{
${ }^{6}$ Russell to Wyke, 1 April 1862. State Papers, Vol. 53, 1862-1863 p. 488

${ }^{7}$ Parliamentary Debates (Commons), Vol. 166, 1862, p. 546.

${ }^{8}$ Muro to Collantes, 9 April 1862. A.D., Vol. 7. 1862, pp.403-404.
} 
would never openly support the idea. Russell told Crampton in Madrid that if the Mexicans "were spontaneously to proclaim a monarchy" they would recognise it, but failing such a proclamation they were happy to negotiate with the present government. ${ }^{9}$ But he wrote to Wyke that he was most concerned that "the French General, anxious for the cause of Monarchy and of Catholic unity, may lend the aid of the French arms to the Reactionary Party in Mexico and thus give fresh life to the civil war, which appears at present to have almost died away."10 Thouvenel, however, had already written to Saligny to emphasise what he had told both him and Jurien before, that the government had never proposed supporting one of the parties that divided Mexico. Knowing as they did now the situation in the country, they did not want to lend their support to principles that were not in harmony with those they professed themselves. Their only hope and desire was to see the time arrive when the Mexicans would find in their presence in the country the moral support to accomplish their own wishes. ${ }^{11}$ If the English saw those instructions they did not allow Thouvenel's words to influence their opinions.

Lord Cowley in Paris seems to have contributed greatly to the suspicion of Napoleon's policy towards Mexico, and also towards Europe. When Thouvenel assured him there was no intention to impose a government on Mexico, Cowley advised Russell of Thouvenel's statement, then said:

But I should deceive your Lordship if I did not record my own conviction that there is a fixed, if unavowed, intention to subvert the Government of Juarez, whatever may be the consequences, whether the renewal of the civil war or not. 12

Russell had a discussion with Flahault after receipt of Cowley's letter and it is obvious he felt as Cowley did. He criticised the sanction given to Almonte's arrival in Mexico by the French and declared it was well known that his purpose in going was "to raise a civil war

\footnotetext{
${ }^{9}$ Russell to Crampton, 19 April 1862. State Papers, Vol. 53, 1862-1863, pp.497-498.

10 Russell to Wyke, 30 April 1862. Ibid., pp. 519-520.

${ }^{11}$ Thouvenel to Saligny, 30 april 1862. AMAE: CP Mexique, Vol. 58.

${ }^{12}$ Cowley to Russell, 2 May 1862. State Papers Vol. 53, 1862-1863, p. 523.
} 
in Mexico, to subvert the existing Government, and to put himself and his partizans in their place."13

Shortly after these discussions news of the suspension of the Convention of London by the Plenipotentiaries in Mexico reached their governments. Both the English and the Spanish immediately blamed Jurien's behaviour and the protection of Almonte for the rupture, and claimed they themselves had adhered strictly to the Convention of London. But France was able to refute this argument, for although Almonte had gone to Mexico with Napoleon's blessing, it was assumed that by the time he arrived the allied forces would have made their demands of the Mexican government and have reached the city of Mexico. As Minister without portfolio, Billault said to the Corps législatif in June 1862, everyone believed that by March the aims of the three governments would have been achieved and the Mexicans given the freedom to choose their own government. It could not be said then, he argued, that France had sent Almonte to start a civil war. When he did arrive and was under the protection of the French flag, Jurien and Lorencez had prevented him from taking any action and it was not until after the rupture that he had been free to act according to his own political opinions. Therefore, the arrival of General Almonte could not be considered the cause of the rupture between the allies. ${ }^{14}$

But whatever were the reactions of the other governments, France was now left alone "to sort out this chaos of difficulties", as Thouvenel put it to Flahault. He remarked that from one point of view it was probably not a bad thing that only one nation was left to sort it out, but it also meant that their responsibility was greatly increased, particularly if they had a setback. Thouvenel could only hope that seven thousand French soldiers could get the better of the Mexican guerrillas. He said that Saligny had been formally advised that he was not to introduce the candidature of Maximilian, as France would not support it unless it was genuinely accepted by the country itself. He hoped at this point that Russell and Palmerston, glad to be out of an affair about which

\footnotetext{
${ }^{13}$ Russell to Cowley, 5 May 1862. Ibid., pp.525-526.

${ }^{14}$ Billault to Corps Legislatif, 26 June 1862. A.D.. Vol. 8, 1862, pp.199-200
} 
they were not happy, would not now accuse France of having violated the London Convention. ${ }^{15}$

Russell, however, still found reason "to complain of the conduct of the Emperor in regard to Mexico", although he was in fact concerned about protecting himself before the parliament. He recalled to Cowley the Emperor's letter to Flahault of the previous October which suggested the redress of their wrongs be

an ostensible object and that our real object should be the setting up of a monarchy in Mexico. I told Flahault that we could never concur in such a course, and at his request I did not even mention this letter to the Cabinet.

But the plan has been pursued secretly first long before the proposal for a joint convention, and openly since the signature of the Convention.

The whole foundation of my policy consists in non-intervention, and I could never concur in a flagrant project of intervention. ${ }^{16}$

In claiming earlier that he was ignorant of the proposal of Maximilian, Russell had in fact played a devious game in trying to protect his own integrity within parliament. Now he was faced with a discussion in parliament on the making and breaking of the Convention and the intentions of the allies in concluding it, and it was impossible to admit that he had known of Napoleon's ideas regarding a possible change of government and the suitability of a monarchy in Mexico, or more especially, that he had actually agreed with the concept.

Thouvenel's instructions to Saligny after the breakdown expressed the regret felt by the government at the breakdown, but reiterated their desire to see Mexico reconstituted under new conditions. He stressed categorically that the initiative for such a regeneration must not come from the French but from the country itself, which would develop its confidence to undertake such a task from the presence of the French. Saligny was told to observe strictly the instructions he had been sent previously, and that although the Emperor and the government had confidence in the character of Almonte, Saligny was to confine his own actions to the responsibilities given him and to leave

\footnotetext{
${ }^{15}$ Thouvenel to Flahault, 17 May 1862. L. Thouvenel, Le Secret de l'Empereur, pp, 301-302.

${ }^{16}$ Russell to Cowley, 28 May 1862. PRO: PRO 30/22/105, Russell Papers.
} 
Almonte to act according to his own convictions in appealing to the patriotism of his fellow countrymen.

While the Emperor was disappointed that the opportunity to accomplish a united action with Spain and England had been thwarted, he believed that what they were trying to achieve in Mexico would not only serve their interests, but also those of the whole world. At least now that they were freed from the "regrettable convention of Soledad" he would be able to give his actions a more decisive character. ${ }^{17}$ The important thing to note is that the Emperor and his government were in complete agreement that the honour of France could not allow them to withdraw, as their allies had done, without achieving anything - neither reparation for what was owed them nor the assurance that any agreements made with the Mexican government would continue to be upheld in the future. Thouvenel wrote to Barrot in Madrid that in accomplishing those tasks they were prepared to give their moral support to the group they believed worthy of it, and he concluded:

En agissant ainsi, nous avons la confiance de servir la cause de la civilisation et nos propres intérêts que nous ne séparons pas dans ces régions lointaines, de ceux des alliés qui ont signé avec nous la convention de Londres. ${ }^{18}$

Despite their differences over the causes of the suspension of the Convention, the three governments were anxious they should not interfere with their friendly relations, and neither England nor Spain opposed the Emperor's decision to stay in Mexico. The Emperor was then greatly disturbed when he heard that Wyke had returned to Mexico City to conclude a treaty with the Mexican government to settle the British claims. By this action Wyke was giving his moral support to France's enemy and his presence in the capital was an act of opposition to France. Napoleon asked if this was the return he was to get for his mediation in the "Trent Affair" which had surely helped prevent a war between England and the United States.

\footnotetext{
${ }^{17}$ Thouvenel to Saligny, 31 May 1862. A.D., Vol 9, 1863, pp.322-323.

${ }^{18}$ Thouvenel to Barrot, 10 June 1862. Ibid., pp. 327-328.
} 
England's position was really rather controversial, for while its ministers expressed doubts over the likely success of Napoleon's efforts, they privately believed it was a good thing and if it succeeded would benefit them also, at no cost to them. Thouvenel asked Flahault to intercede with Russell to determine England's position regarding Wyke's actions, but the English government had already decided not to ratify the treaty prepared by him. In the House of Lords there was some discussion about Mexico, and rejection of French public opinion that England had deserted France at a crucial time. Russell said England could not be accused of withdrawing its troops from Mexico because at no time had it had any land troops there anyway. At the same time Lord Malmesbury, a former Foreign Minister criticised the behaviour of Wyke who had been seen in Mexico openly supporting the Juarez government. He did not think, however, there was much public feeling in Britain about what France was about to do in Mexico, but he felt the French had made a mistake in policy and would pay for it. On the other hand he had to say that any change in government in Mexico would be an improvement and "the people of Mexico and the world generally were likely to profit by the acts of the French, however opposed those acts might be to the interests of France."19

After this debate Palmerston wrote a note to Russell that he thought it would be an expensive proposition for France which was one more reason intervention was out of the question for Britain. He added, however, that "a monarchy supported by the great armies of Imperial France might be a very different matter. Then the scheme would have a better chance of success and, at no cost to Great Britain, be doubly advantageous to her in Europe as well as in America."20 Thus Russell and Palmerston had succeeded in maintaining their integrity before their own parliament because their action in Mexico did not constitute intervention in Mexico's political affairs. Neither were they now

\footnotetext{
19 Parliamentary Debates (Lords), 19 June 1862. Vol. 167, Third Series, p. 723.

20Palmerston to Russell, 19 June 1862. (PRO: PRO 30/22/22). Quoted by K. Bourne, Britain and the Balance of Power in North America, p.255.
} 
committed to an expensive expedition, but they could see the benefits to be obtained from France shouldering the burden and the expense of an expedition alone.

For its part, the Spanish government was anxious to maintain good relations with France and made many overtures over the following months regarding reconvening the Convention of London and supporting the Mexicans' efforts to establish a more stable government. Without actually saying that the conduct of Prim was regretted, the determination of the Spanish government to reconvene the Convention and assure its alliance with France would seem to indicate this. Napoleon assured the Spanish Ambassador that he had always been anxious to maintain good relations with Spain and that was why he had sent an inferior number of troops initially and instructed his commanders to work closely with Prim. He said that he did not regret the fact that his politics had turned out to be different from Spain's in relation to Mexico, but he did regret that he had mistakenly believed they were the same from the discussions prior to the signing of the Convention. ${ }^{21}$

The fact that France was left alone in Mexico was not the choice of Napoleon and it can be seen that alliances with Spain and England continued to be important to him. Napoleon and his government decided, however, that the time for discussions about reconvening the Convention would be more appropriate after the French army had reached Mexico City and the Juarez government was defeated. At that time France would call on Spain and Britain to come to their aid in supporting the people in their efforts to constitute a new government. The Spanish ambassador was convinced of the sincerity of the Emperor and his government when they said they had no intention of imposing a particular form of government in Mexico, just as he believed they had no plans of conquest or territorial aggrandisement. ${ }^{22}$

\footnotetext{
${ }^{21}$ Marquis de la Havane, new ambassador to France, to Collantes, 1 September 1862. A.D., Vol. 10, 1863, pp. 29-30.

${ }^{22}$ Marquis de la Havane to Collantes, 31 October 1862 . A.D., Vol 10, 1863, pp. 31-32.
} 
The path for Napoleon was not to be easy, however, for in the months of May and June 1862 he was confronted with contradictory reports from his representatives in Mexico which finally made him realise his intentions were misunderstood by his envoys. Firstly he had to try and determine the facts of the situation from the differing reports he received from Jurien and Saligny. Jurien wrote at the end of April that the Emperor had to let everyone know that he was the commander-in-chief of the expedition, otherwise there would be anarchy. At the moment, he said, Lorencez and Almonte were both making proclamations while Saligny signed those that Jurien put before him "and criticised them later if it suited him". This was not yet a problem in Mexico, Jurien thought, "because we are in the presence of a people of monkeys and puppets", but it was important to avoid ridicule in Europe. Jurien was convinced that he was the only one of Napoleon's representatives who had the courage of his opinions, and he said that Saligny never forgot to "keep his nose clean". For example, when Saligny heard about the reaction in Europe to the protection of Almonte, he had tried to convince Jurien that Lorencez had decided to escort him inland against his wishes. "Tomorrow," concluded Jurien, "he will perhaps take all the credit for it."23 It was seen in the previous chapter that Saligny was the one who insisted that Almonte should be allowed to move inland from Vera Cruz.

Then Jurien's colleague, Devarenne, arrived in Paris to enlighten the Ministers and Napoleon on the problems in Mexico. Devarenne explained to the three Ministers, Thouvenel, Chasseloup-Laubat and Randon, all the difficulties that had confronted Jurien on his arrival and that he, Jurien, was the only one who could save the expedition that had begun with such feeble resources. In his first interview with the Emperor he told him that Jurien expected to be in Mexico between 18 and 20 May, that is, about the time he was actually speaking with Napoleon. He informed Napoleon of the duplicity of Saligny who had written to Thouvenel that he disapproved the Preliminaries of Soledad after having congratulated Jurien when he had signed them. But "what could you expect

\footnotetext{
23 Jurien to Thouvenel (Private), 22 April 1862. AMAE: PA-AP 233 Thouvenel, Vol. 10.
} 
from a man whose state of delirium had reached such an extreme", Devarenne suggested. Saligny had already suffered from meningitis ("fièvres cérébrales") five times, and ever since Jurien's arrival he had opposed him and refused to share his knowledge of the country, preferring to remain in Vera Cruz. In spite of all these difficulties Devarenne assured Napoleon Jurien would be in Mexico City where his skill and patience would be indispensable to the success of the enterprise - "the changing of the form of the government." 24

Although Napoleon did not comment to Devarenne on this interpretation of his plans, it will be seen that it caused him great concern, as did his comment that signing the Convention of Soledad had actually produced some advantages for France. If it had not been signed, Devarenne said, the rupture between the allies would have occurred much earlier, and the French would have had to advance without enough arms or equipment. The enterprise then would have ended in disaster. As far as Napoleon was concerned, however, treating with the government with whom he believed they should be at war was contrary to the spirit of the London Convention. Jurien had asked Devarenne to tell the Emperor not to hesitate to repudiate his actions if he was wrong, but to assure him of his appreciation and devotion. Napoleon was quick to reassure Devarenne that he had appreciated Jurien's devotion for a long time and had always considered him a loyal and excellent servant.

He said nothing to Devarenne, but this was probably the first realisation Napoleon had that his representatives had misinterpreted his intentions, and a letter from Lorencez to Marshal Randon would have added even more to his concern. Lorencez wrote that because they were "so superior to the Mexicans in terms of race, organisation, and moral discipline" the Marshal should tell the Emperor that "at the head of his 6,000 soldiers I am the master of Mexico". He added that he hoped the Emperor had not been influenced by letters from Mexico to abandon his projects for the country, or that Maximilian had not been discouraged from accepting "the crown that His Majesty wanted to put on his

\footnotetext{
${ }^{24}$ Devarenne to Jurien, 31 May 1862. AN: BB ${ }^{4} 1814$.
} 
head", because he was more convinced than ever that a monarchy was the only suitable form of government for Mexico. He concluded that it was true he was moving slowly towards Mexico City but he had to take all his supplies with him and he did not want his men marching for too long under the very hot sun, "but I will surely arrive there, the government of Juarez will be overturned and Prince Maximilian will be proclaimed."25

Napoleon's reaction to this is revealed in an angry letter he wrote to Maximilian shortly after the arrival of this report. He said:

I have always ... gone straight upon my way. Being at war with the Mexican Government I have not been willing to treat with it. I have told my representatives that there was no question whatever of imposing any kind of government upon the Mexicans, but only of supporting a monarchy if it found partisans in the country and a prospect of stability. This course of action was quite simple and straightforward, and yet attempts have been made to distort my intentions and misinterpret the character of the intervention. ${ }^{26}$

To Lorencez he wrote:

Il est contre mon intérêt, mon origine et mes principes, d'imposer un gouvernement quelconque au peuple mexicain. Il peut choisir en toute liberté celui qui lui convient le mieux. Je ne lui demande que de la sincérité dans ses relations avec l'étranger, et je ne désire qu'une chose, la prospérité et l'indépendance de ce beau pays, sous un gouvernement stable et régulier. ${ }^{27}$

This spontaneous and angry response of Napoleon is difficult to dismiss, and although other historians have had access to a large proportion of the correspondence I have used, they have still concluded that Napoleon was playing a double game and that his representatives were carrying out his instructions. Their position is difficult to maintain in view of what I have already shown and of further correspondence supporting Napoleon's statements above.

It cannot be denied that Napoleon had anticipated little serious resistance to the idea of a change in the regime in Mexico, nor that he thought a monarchy best, but he always

\footnotetext{
25 Lorencez to Randon, 26 April 1862. Service Historique de l'Armée de Terre (SHAT) Archives du Ministre de la Guerre, (AMG) $\mathrm{G}^{7}$.

${ }^{26}$ Napoleon to Maximilian, 7 June 1862. Quoted by Egon Corti,Maximilian and Charlotre, pp. 372-373.

${ }^{27}$ Napoleon to Lorencez, June 1862 (no exact date). A.D., Vol. 10, 1863, pp. 72-73.
} 
was open to an alternative result. He wrote to Maximilian in January 1862 expressing this belief, and in his reply Maximilian showed that the project of his appointment to the throne of Mexico was not an act that was to be taken for granted. He told the Emperor how proud he would be to hoist the monarchical flag aloft in Mexico "in case I am called upon to reign", indicating that although the Emperor was fairly certain this would eventuate he did not treat it as a fait accompli. ${ }^{28}$ A further letter from Napoleon in March revealed that the information from Mexico, which included correspondence from the Prussian and Belgian representatives, indicated there was much support for a monarchy. Napoleon assured Maximilian that he was doing all he could to see this eventuate, but from Maximilian's reply it can be seen that Napoleon had previously advised him that he should reserve his expectations until the freely expressed desires of the Mexican people, regarding the form of government they wanted, were known. ${ }^{29}$

The correspondence between Napoleon and Maximilian, published by Corti, actually supports the argument that Napoleon's proposal of Maximilian and his discussions with him were merely part of his contingency plans should the people vote in favour of a monarchy. That Napoleon was not opposed in principle to a republican form of government is supported by the writings of his youth in which he recognised the virtues of both forms of government, and that neither was the better per se. In Des Idées napoléoniennes he wrote:

il n'y a pas plus de formule gouvernementale pour le bonheur des peuples, qu'il n'y a de panacée universelle qui guérisse de tous les maux. ... Tous ont été bons, puisqu'ils ont duré; telle forme a été la meilleure pour tel peuple qui a duré le plus longtemps. Mais a priori, le meilleur gouvernement est celui qui remplit bien sa mission. C'est-à-dire celui qui se formule sur le besoin de l'époque, et qui, en se modelant sur l'état présent de la société, emploie les moyens nécessaires pour frayer une route plane et facile à la civilisation qui s'avance. ${ }^{30}$

Napoleon's instructions to Jurien and Lorencez confirm he still maintained these ideas of his youth, and it will be seen below that they were reiterated in the instructions to General

\footnotetext{
${ }^{28}$ Napoleon to Maximilian, 14 January 1862. Quoted by Egon Corti, Maximilian and Charlotte, pp.365-366. Maximilian to Napoleon, 22 January 1862. Ibid., pp.367-368

${ }^{29}$ Napoleon to Maximilian, 7 March 1862. Maximilian to Napoleon, 15 March 1862. Ibid., pp. 371-372.

30 Napoleon III, "Des Idées napoléoniennes", pp. 22-24.
} 
Forey who was shortly to replace Lorencez as commander of the Expeditionary Forces.

Thouvenel also had supported these sentiments in his discussion with the Spanish Chargé d'Affaires in early April.

It can be said, though, that Napoleon believed at this point in time that a monarchy was more likely to eventuate than not eventuate in Mexico, based on the premise that the Juarez regime would fall easily. Not only had he been led to believe, by Saligny and other correspondents, that Juarez could not continue to hold power, but independent, seemingly reliable observers, such as the Prussians and Belgians, told him of the rising strength of the Monarchical Party in Mexico. Despite these encouraging reports Napoleon always maintained some reserve and anticipated the possibility that the people might not vote in favour of a monarchy. The question of how this was to be decided, however, raised as much debate among contemporaries as historians and will be discussed below in Chapter 7.

Regardless of Napoleon's statements to Maximilian and Lorencez, the general belief, even in his own country, was that he was determined a monarchy should be installed in Mexico. Le Temps criticised this, but commented that perhaps there were reasons for supporting Maximilian's candidature which so far the government had failed to explain to the people. The journalist asked what the motive could be. Was it really about the "duel" between the latin and anglo-saxon races, or was it rather something "less chimerical" - the question of forming a European barrier to the expansion of the United States? If that was really the aim, then the conduct of England gave France something to think about. He continued:

L'Angleterre est certainement la puissance du monde la plus intéressée à s'opposer à l'agrandissement des Etats-Unis, et cependant l'Angleterre se retire de l'action; mais en même temps elle applaudit ì notre entreprise. Par l'organe de Lord Russell, elle déclare qu'il ne lui appartient point d'intervenir dans les affaires intérieures d'une nation étrangère. Par l'organe de son plus puissant journal, elle ne cesse de nous applaudir et de nous encourager et les encouragements du Times sont à la fois ironiques et sincères. Les forces et les préoccupations de la France détournées en partie de l'Europe, et engagées dans une entreprise lointaine, de plus un conflit possible entre la France et les Etats-Unis: voilà des perspectives qui ne peuvent que réjouir les Anglais, et qui leur promettent des avantages 
certains, de quelque manière que tournent les événements. La seule question est de savoir s'il est de notre intérêt de réjouir les Anglais. ${ }^{31}$

This perceptive analysis reveals two things: firstly that the view of the world attributed to Napoleon as his grande pensée, encapsulated ideas that were shared by others at the time; and secondly, that there were people aware of the concerns of England about possible activities of France in Europe, and that England hoped to gain advantages in the Americas from what France was doing, at no expense to themselves. Yet although the effect on Europe of the aggrandisement of the United States was considered by many European observers, the Emperor did not share this as a motive for his involvement in Mexico with the French parliament or the public until his instructions to General Forey of July 1862 were published, in part, in 1863 in the Archives Diplomatiques. According to General Comte Fleury, an aide to Napoleon, this was a mistake, because the war would not have been so unpopular if all Napoleon's motives had been revealed much earlier.

Fleury believed that by withholding his "elevated motives" from the public and the parliamentary chambers, Napoleon had actually jeopardised the expedition, and as a consequence his motives were widely misinterpreted and misunderstood. He thought that if the Emperor had been more frank with his friends, the parliament and the public he would have had more support for his ideas, but unfortunately, he said, discussion was not permitted on diplomatic problems, when in fact it might have lessened the difficulties. However, when it is remembered that these events were taking place in the very early days of the move towards a more liberal Empire, this absence of discussion can be understood. Fleury's comments were also made with the advantage of hindsight. The consequences, however, were grave, Fleury believed:

Cette discretion imposée par la politique n'a pas eu seulement l'inconvénient grave de discréditer les projets mal connus de l'Empereur. Elle a pesé lourdement sur la conduite et la préparation des opérations militaires, parce que, n'osant pas tout dire aux Chambres, on a lésiné dès le principe sur l'envoi des moyens nécessaires pour en assurer le succès. ${ }^{32}$

\footnotetext{
${ }^{31}$ Le Temps, 30 May 1862.

${ }^{32}$ Général Comte Fleury, Souvenirs du Général Comte Fleury (1859-1867) 2 Vols. (Paris, 1898), Vol. 2, p. 265.
} 
There is a lot of merit in what Fleury had to say, as the public and members of both the government and opposition were not unmindful of the power of the United States in its position in the New World, and the benefits they had already gained from Mexico in the form of territory. The problems that Mexico had suffered at the hands of that nation were discussed in Le Temps and commented on by Mazade in one of his articles on the Mexican campaign. ${ }^{33}$ Also, in 1862 Guizot, former Minister during the July Monarchy, had a conversation with the distinguished English traveller and writer, Nassau Senior, in which he spoke of the history of the relations between the United States and Mexico that he had had drawn up when he was in office. He remarked that; "Never was a nation treated with such injustice, such insolence, such perfidy, or such cruelty, as Mexico was by the United States." He thought that the United States had done all it could to keep the country weak and anarchical in order to rob it of its resources and territory, and concluded that they had "no scruples, no public morality, and no fears. They are terrible neighbours. I am glad that the Atlantic is between us."34 But in spite of the support that may have been present for Napoleon's policy if he had revealed it, this was not done.

In the debate in the Corps législatif towards the end of June, the Opposition aired its disapproval of the claimed intention to overthrow Juarez and institute a monarchy. Jules Favre remarked that it was obvious that the Government had been misled by inaccurate information and that in fact the Juarez regime was not going to be easily overthrown. It was also apparent that the Mexican government had at least enough "vitality" to have united the population to resist the French, he said, referring to the fact that the French army had been defeated at Puebla in May. ${ }^{35}$ Billault, for the government, rejected Favre's suggestions that they should now treat with Juarez and leave Mexico as soon as possible. How could they do that, he asked, when all the promises of the Mexican government had proved worthless, when French blood had already been spilt and they had suffered a military setback? Withdraw, when at this sad news the

\footnotetext{
${ }^{33}$ Charles de Mazade, "La Guerre du Mexique", p. 738.

${ }^{34}$ Conversation between Guizot and Senior, 11 April 1862. Nassau William Senior. Conversations with Distinguished Persons during the Second Empire (London, 1880), Vol. 2, p. 168.

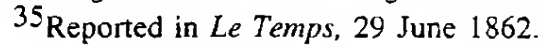


patriotism of even the Opposition had been moved to vote in favour of the fifteen million francs that had been asked of them? Billault continued to appeal to their patriotism and to the fact that France's honour had now been engaged. In view of its glorious past France would suffer considerable humiliation if the army returned home without having achieved any military satisfaction after this setback, he concluded ${ }^{36}$ This appeal to the deputies succeeded, and it was for this reason that they voted in favour of the extra money needed to send reinforcements to Mexico. Émile Ollivier, however, commented disparagingly on this episode:

nous le votâmes et je dis pourquoi: "Nous sommes unanimes sur ce point, c'est que là où nos soldats sont engagés et souffrent, peu importe pour quelles raisons et dans quelles circonstances, il faut les secourir. En votant ce secours, je le dis à l'avance, nous ne renonçons pas au devoir de rechercher ce que nos soldats sont allés faire au Mexique et quelle attitude il convient que nous imposions ou conseillons au gouvernement (16 juin)." 37

Overtly the support was there in the form of the vote in favour of the budget for Mexico, but Ollivier maintained that the facts of the situation were altered or deliberately misconstrued by Billault to mislead the country.

Although the Emperor must have been surprised at the unexpected defeat of his army at the fortified town of Puebla in early May his initial reaction to Lorencez was an acceptance that in war these setbacks occur and he should not be discouraged. He wrote that the honour of France had been engaged and the general could expect all the resources that he needed to continue his move towards the capital. ${ }^{38}$ But his anger was very quickly roused by the ensuing reports that arrived from Lorencez and Saligny criticising in violent language the behaviour and integrity of each other. The first was from Saligny in the form of a personal damnation of Lorencez with whom he tried his hardest to get on. He wrote to Thouvenel:

... esprit craintif, paresseux, endormi, pour ne pas dire éteint, caractère faible, incapable lui-même d'initiative et ne pouvant souffrir celle d'autrui; ne demandant jamais de conseils et prenant ombrage de ceux qu'on lui donne, il joint à tout cela une susceptabilité, maladive, toujours en éveil et

\footnotetext{
${ }^{36}$ Billault to Corps législatif, 26 June 1862. A.D., Vol. 8, pp. 209-210.

${ }^{37}$ Emile Ollivier, L'Empire libéral, Vol. 5, p.412.

${ }^{38}$ Napoleon to Lorencez, June 1862 (no exact date). A.D., Vol. 10, 1862, pp.72-73.
} 
que les plus grands ménagements, les déférences les plus empressées ne sauraient rassurer. Il est, en outre, sujet à de fréquentes absences qu'on prendrait parfois pour de l'aberration à des accès d'humeur ivre qui le rendent pendant plusieurs jours inabordable, même pour son entourage, avec le quel [sic] il est d'ailleur's, sur un pied de continuelle méfiance, presque d'hostilité. 39

This was followed by Lorencez's lengthy report to Randon of what had happened at Puebla, and that the blame for their setback belonged mostly to Saligny and Almonte who had misled him as to the support he would receive and the strength of the opposition he would encounter. He was amazed at the strength of the defence he encountered when, according to the assertions of Almonte and Saligny, "a hundred times repeated", he would be welcomed with transport for his journey to Mexico City, and his soldiers would be covered with flowers. He was faced then with three options: to attack the barricades of Puebla directly, a project his commanding officers of the engineers and artillery advised against as they would lose at least a thousand men in the attempt; to go around Puebla and head to the capital, which was not feasible because of limited supplies; or to retreat to Orizaba to await the arrival of supplies and equipment strong enough to destroy the town of Guadaloupe in order to reach the capital. Following advice from Saligny and Almonte that the army of General Marquez was coming to meet him at Amazoc on the route to Orizaba, Lorencez decided on the third option and proceeded to Amazoc where he waited for three days. As there was no sign of Marquez and news reached them that the head of the Reactionary Party, Zuloaga, had made a pact with Juarez to neutralise the army of Marquez, Lorencez decided to continue his retreat to Orizaba. On the way he encountered Marquez who said he had come by another route far from the direction of Puebla, and had never been to nor intended to go to Amazoc, a statement that was in direct opposition to the assertions of Saligny and Almonte. 40

Lorencez added to this another despatch condemning Saligny and the reports he had heard he had written against himself and the army. He had received information that Saligny wanted to try and prevent his mail leaving the country so only his own reports

\footnotetext{
${ }^{39}$ Saligny to Thouvenel (Confidential), 8 May 1862. AMAE: CP Mexique, Vol. 58.

40 Lorencez to Randon, 22 May 1862. AMG: $\mathrm{G}^{7} 1$.
} 
reached Paris, which led Lorencez to take extraordinary measures to ensure his despatches reached the boats safely. He told Randon that Saligny was not well thought of in Mexico and had done nothing for the French there but mislead them. He continued with a condemnation of Saligny similar to Saligny's report of him:

Il est entièrement inepte en affaires; sans aucun jugement, il n'a d' autre aptitude que la déplorable facilité d'écrire des mensonges; son manque de dignité et ses habitudes d'intempérarice, l'ont placé dans l'opinion de l'armée, à un rang de beaucoup au dessous de celui que sa position officielle lui donne. D'un jour à l'autre je me vois dans l'obligation de faire arrêter M. le Ministre de France au Mexique et de le faire embarquer. ${ }^{41}$

What was Napoleon to make of what was happening in Mexico, especially when a further report arrived from Saligny at the same time criticising the approach of the army to Puebla, and giving his view of why they were defeated there? Saligny told Thouvenel that if they had marched straight to Mexico City, as he believed the Emperor wanted, without waiting for supplies all would have been well and Puebla would not have been fortified. Jurien's claims of lack of transport in the early stages were totally false, he said, because a Mexican had offered lots of horses and equipment which Jurien rejected. 42 It is hard to imagine that one Mexican could have had enough equipment to meet the needs of the army, but this report was enough to anger Napoleon and cause him to direct Marshal Randon to censure Lorencez for having made an imprudent attack against Puebla, and for criticising Saligny, his representative in Mexico. Napoleon had decided to accept Saligny's views of the situation in Mexico over those of his appointed commanders. Just why he did this can be seen in his lengthy instructions, which were written in the next few days, to General Forey, who was now to take command of the expedition.

But in the meantime Marshal Randon wrote to Napoleon after carrying out his instructions, and strongly criticised the unfair judgement of Lorencez that was based on the observations of a person entirely alien to the army. He continued:

\footnotetext{
${ }^{41}$ Lorencez to Randon, 24 May 1862. AMG: $\mathrm{G}^{7} 1$.

${ }^{42}$ Saligny to Thouvenel, 26 May 1862. AMAE: CP Mexique, Vol. 58.
} 
Ce n'est pas seulement le général de Lorencez qu'attaque M. de Saligny; l'amiral Jurien n'est pas épargné, puis le colonel Valazé et l'état major tout entier. ... En lisant les dépêches de M. de Saligny, en examinant la valeur de ses appréciations, il est bien permis de sourire et de ne pas prendre au sérieux ses raisonnements pour critiquer les opérations des troupes. . . . Quel est le général qui consentirait à se charger d'un commandement si ses moindres actions de guerre devaient avoir pour juge un homme qui, placé près de lui pour une tout autre mission, s'arroge le droit de scruter sa conduite et dénoncer ses actes? ${ }^{43}$

There have been many criticisms levelled at Napoleon for approving the conduct of Saligny over that of his commanders, but faced with all the contradictory reports coming from Mexico he had to make a decision on what was the most reliable information. Saligny had been in Mexico much longer than Jurien or Lorencez, and before their arrival there had been no reason to doubt the verity or integrity of his reports. In addition, the observations of such presumably reliable people as the Ministers and Consuls of Belgium and Prussia, which agreed with Saligny's views, added more weight to his reports. Rightly or wrongly Napoleon made a decision to support Saligny, but to avoid further complications he invested Forey with both political and military powers and made sure that his instructions were clear and precise, even going so far as to outline in detail how he would conduct the military operations if he were in Forey's place.

These instructions are extremely important for two reasons: firstly that they explain Napoleon's reasons for accepting Saligny's reports over those of his commanders; and secondly because Napoleon's view of the Mexican situation and his aims for the expedition are so clearly expounded. In support of Saligny Napoleon told Forey he had seen a report from the Belgian Consul in Puebla and received letters himself from that town, which stated that the day after the French had been checked at Puebla the population in the town had been amazed that they had not succeeded in taking it.

Napoleon said he had also seen letters from Mexico City, including reports from the Belgian and Prussian Ministers, which said that before 5 May

le gouvernement était dans la stupeur et que la population nous attendait avec impatience comme des libérateurs. Ainsi le Général Lorencez, n'a pas été trompé par les rapports de M. de Saligny et du Général Almonte car s'il avait

${ }^{43}$ Randon to Napoleon, 2 July 1862. Quoted by Emile Ollivier, L'Enpire libéral, Vol. 5, pp. 408-409. 
réussi dans l'attaque de Puebla tout ce que ces messieurs lui avaient annoncé se serait réalisé. ${ }^{44}$

These reports, Napoleon told Forey, actually confirmed what Saligny had always said. He had not said the population was so enthusiastically in favour of their intervention that they would immediately rise up and overthrow their oppressive government, but he had said that once they were in the interior of the country they would find the population sympathetic. He added that although he did not know if Saligny's character left something to be desired, or if he could be reproached for his intemperate language, he believed his despatches had always shown good sense, steadfastness, and a concern for the dignity of France. It was therefore probable that if his advice had been followed the French flag would already be flying in Mexico City. He impressed upon Forey how important it was now that he get along with Saligny who knew the country and was au fait with the claims that were to be redressed. This unity was stressed as being essential because of the disagreements and jealousies that had caused everything to be compromised in Mexico so far.

Napoleon then for the first time openly discussed the idea of restraining the advancement of the United States as a motive for the intervention in Mexico. It should be remembered that this had already been expounded by Le Temps on 30 May as a valid reason for France being involved in Mexico, and one that England was openly applauding, especially as that country would benefit at no expense to itself. Europe, Napoleon said, could not be indifferent to the prosperity of America because it provided raw materials for their industries and markets for their commerce. Although Europe was interested to see the United States powerful and prosperous it did not wish to see it seize all the Gulf of Mexico from which it could dominate the Antilles and South America and thence be the sole administrator of the products of the New World. He continued:

Maîtresse du Mexique et par conséquent de l'Amérique centrale et du passage entre les deux mers, il n'y aurait plus désormais d'autre puissance en Amérique que celle des états unis.

\footnotetext{
${ }^{44}$ From a draft of a letter possibly written to Marshal Randon dated 14 July 1862 , having exactly the same content as the letter written to General Forey 3 July 1862, but adding explicit instructions on what Forey was to do in Mexico on his arrival. AN: 400AP 62, Archives Napoléon.
} 
Si au contraire le Mexique conquiert son indépendance et maintient l'intégrité de son territoire, si un gouvernement stable s'y constitue par les armes de la France, nous aurons posé une digue infranchissable aux empiètements des états unis, nous aurons maintenu l'indépendance de nos colonies des Antilles et de celles de l'ingrate Espagne; nous aurons établi notre influence bienfaisante au centre de l'Amérique et cette influence rayonnera au nord comme au Midi, creeera des débouchés immenses à notre commerce et procurera les matières indispensables à notre industrie. ${ }^{45}$

In an analysis of this letter $\mathrm{A}$. and $\mathrm{K}$. Hanna commented that there was no mention of "debts, claims, and damages to French nationals" and say this is revealing in the light of "the almost hysterical devotion to French 'griefs', so much a part of earlier policies". They concluded that "now that they were no longer needed to mislead England and France [sic], they were not even mentioned." 46 This is not strictly accurate, as Napoleon did mention them when he spoke of the aim not being to impose a government but to support the Mexicans to establish the kind of government they wanted, and which had some chance of stability and of guaranteeing to France redress for the "griefs of which they had to complain". This issue was not neglected, but now that the honour of the country was engaged, Napoleon focused more on getting the expedition back on track and on the issue of the institution of a new government as a prerequisite for the settlement of France's claims.

American historians particularly have concentrated on what they call Napoleon's anti-American policy as the principal motive for his intervention in Mexico, and played down the fact that he was also highly motivated by the idea of helping Mexico regenerate itself. A. and K. Hanna and Perkins relied heavily on the writings of Michel Chevalier in their arguments, believing that because of his close association with Napoleon his ideas must necessarily be those of the Emperor. ${ }^{47}$ Chevalier, however, gives no indication, implied or explicit, that what he wrote regarding Mexico and the Americas also reflected the Emperor's ideas. He had studied the growth of other Christian powers in the world, including Russia which embraced the Orthodox religion; the nations rising from the

\footnotetext{
45 Ibid.

${ }^{46}$ A.J. and K.A. Hanna, Napoleon III and Mexico, pp. 77-79.

${ }^{47}$ Dexter Perkins is the author of The United States and Latin America; The History of the Monroe Doctrine; The Monroe Doctrine 1826-1867, among other books on American Foreign Policy.
} 
imminent collapse of the Turkish Ottoman Empire that would lean towards the Greek Church; the growth of the Protestant States of the United States, Canada and the Pacific and suggested that they would threaten the future of Catholic nations like France. He wrote:

This comparative exhibit of the progress of Catholic States and those of the Christian peoples that profess other tenets, is of a nature to inspire gloomy reflections in those statesmen who, not without reason consider that the destinies of France, and the greatness of her authority, are dependent on the chances of the future of the Catholic States in general, and of the Latin races in particular. It is the most powerful argument that can possibly be put forward in support of the expedition to Mexico. ${ }^{48}$

These ideas, though, seem to be in opposition to those of Napoleon who was concerned that those of other religions should be allowed the freedom to worship as they chose. His determination to reduce the power of the Catholic Church both in France and Mexico bear witness to this.

That Napoleon was hoping for some benefit for France cannot be denied, but it is difficult to say that he was seeking advantages for France alone when so much of his negotiation before the expedition began was to ensure that the intervention was only undertaken as a joint venture with the two nations with whom he believed it was essential to have strong alliances. The statement in his letter to Forey about the Prince aided by France being bound to act in their interests, has also been used to support the argument that Napoleon intended from the beginning to impose a monarchy. However, there are also two references in the same letter to the importance of the Mexicans being able to choose the form of government they believed was best for them, whether that be a monarchy or a republic. The fact that Napoleon added the following comment to his direction that an assembly be convoked to decide the form of government most suitable for Mexico, does not negate everything he said about the Mexicans exercising free choice in this regard.

Il va sans dire que si les Mexicains préfèrent une monarchie, il est de l'intérêt de la France de les appuyer dans cette voie et en ce cas le Général

${ }^{48}$ Michel Chevalier, Mexico, Ancient and Modern, Vol. 2, p. 216. 
[Almonte] pourrait indiquer l'Archiduc Maximilien comme le candidate de France. 49

The setback at Puebla, though, changed the nature of the intervention so that it now became a matter of honour to march to Mexico City and ensure that security in France's future relations with Mexico would be obtained. But this did not change Napoleon's conviction that the form of government had to be decided by the people. He summarised the situation in the conclusion of his letter to General Forey:

Ainsi donc aujourd'hui notre honneur militaire engagé, l'exigence de notre politique, l'intérêt de notre industrie et de notre commerce, tout nous fait un devoir de marcher sur Mexico, d'y planter hardiment notre drapeau, d'y établir soit une monarchie, si elle n'est pas incompatible avec le sentiment national du pays, soit tout au moins un gouvernement qui promette quelque stabilité. 50

For diplomatic reasons, this letter was not made available to the French chambers or published in the Yellow Books (Archives Diplomatiques) until early in 1863, and then only in a heavily edited form. Deleted most notably was reference to the concern for Europe of the United States having control over Central America and the passage between the Atlantic and Pacific Oceans, and as a result being the only Power in the Americas. In its place was added the observation of how precarious the success of an industry was when it was dependent on only one market for its raw materials. This did not sound as antagonistic towards the United States as the original comment may have to the public and the opposition, but it may also have made the expedition appear to have been an expensive exercise for such limited reasons, even though those reasons were not published for a year.

Fleury commented that the expedition was ultimately compromised because Napoleon was unable to get enough support to have the funds needed for the campaign voted by the parliament, because they were unaware of his "elevated motives". But if Napoleon was determined to achieve these aims through the Mexican campaign why did he not place more importance on it? At exactly the time he expounded his aims in Mexico ${ }^{49}$ Napoleon to Forey 3 July 1862 , (draft dated 14 July). AN: 400 AP 62 , Archives Napoléon.
50 Ibid. 
to Forey, he replied to requests by two of his generals, obviously to send stronger command there, that he did not think the Mexican expedition was important enough to send a General to command the Engineers or one to command the Artillery. He did not say he only anticipated a short campaign, or that the war was not big enough to warrant sending generals to command these sections of the expeditionary forces, but he told both General Lebœuf, who asked to be sent with General Forey, and General Frossard a close aide-de-camp, that it was not important enough to do so. To General Frossard he wrote this note:

Mon cher Général, L'expédition du Mexique n'a pas assez d'importance pour y envoyer un Général du Génie, c'est l'unique raison qui m'empêche de satisfaire le désir que vous m'exprimez. ${ }^{51}$

If it was not so important that it needed a group of senior officers to command it, what did Napoleon really think of the campaign? It is obvious that the maintenance of European influence in Central America was essential to his vision, but these comments show he was not prepared to use excessive force to see that vision materialise. By the same token he had been led to underestimate the strength of Juarez and his support. As Ernest Louet, paymaster of the French forces in Mexico, observed, the intervention had been based on the premise that Juarez would be easily overthrown, and hardly anyone doubted the success of the expedition at the beginning. He rightly said, there were very few "wise spirits, more prudent, more reflective than others" who realised that Juarez had the advantage of being able to sustain himself and his supporters in some part of the huge country which was impossible to be occupied in its entirety by enemy forces. Juarez, he believed, would always be able to find some shelter to escape his enemies and wait for better times, and could feel secure in the support, direct or indirect, of his northern neighbours. ${ }^{52}$ But this was yet to be realised in Paris where it had been decided to pursue the war because France's honour had been engaged.

\footnotetext{
${ }^{51}$ Note from Napoleon to Frossard, 5 July 1862. AN: AB XIX 172. The remark to General Lebcuf is mentioned by Emile Ollivier in L'Empire libéral, Vol. 5, p. 411

52Paul Gaulot, L'Expédition du Mexique, Vol. 1, pp. 56-57.
} 
With the despatch of Forey to Mexico the campaign was about to move into another phase which Napoleon hoped would be better directed as a result of the precise instructions he had given, and the clarification of his aims. Because the honour of France had been engaged by the defeat at Puebla, it was now a different campaign. Yet despite all of Napoleon's efforts it was to demand far more resources and far more time than he possibly could have anticipated. The months ahead revealed even more problems with his representatives and the realisation that he had, indeed, been badly served. The hesitations of Maximilian when the crown was finally offered to him, at a time when opposition in France was building up and European issues were occupying him, gave rise to even more criticism of Napoleon. 


\section{Chaptex 6}

\section{但upltity Revealed}

Before Forey arrived in Mexico Napoleon and his Minister, Randon, were besieged with conflicting reports from Lorencez, Saligny and Almonte in the aftermath of the defeat at Puebla. Lorencez wrote that the financial measures taken by the other two were "deplorable", and there was not enough money to pay the Mexican troops adequately to stop them pillaging and giving the French army a bad reputation. ${ }^{1}$ Almonte in the meantime wrote to Napoleon that Lorencez and his assistant, General Douai, did not understand Mexican warfare and refused to listen to his advice which would have seen them defeat the army of General Zaragoza. There was no other army between Orizaba and Mexico City, Almonte claimed, and he had heard from the capital that there were no more forces to send against them, so if Lorencez listened to him, Juarez could be put down easily. ${ }^{2}$ Almonte's confidence in his knowledge of his country, and his belief that he understood the Emperor's politics, was a major cause of the problems that arose in how to conduct the campaign. He complained to Napoleon that if Lorencez had followed his advice they would have been in Mexico City within two months. His continued presence in Mexico would be more harmful than useful to the Emperor's politics, Almonte added, and "it would be prudent to recall him, if Your Majesty believes it advisable, as I do."3 It is doubtful that Napoleon had anticipated such presumptuous advice from Almonte when he sanctioned his departure for Mexico, but it is obvious that his and Saligny's criticisms of Lorencez to this point were accepted by him.

Lorencez, however, came to the conclusion that there was little support for the French in Mexico, that the Moderate Party did not exist, and that the Reactionary Party was reduced to nothing and was in any case "odious". Most of the Mexicans, he said,

\footnotetext{
${ }^{1}$ Lorencez to Napoleon, 23 June 1862. AN: 400AP 62, Archives Napoléon.

${ }^{2}$ Almonte to Napoleon, 24 June 1862. AN: 400AP 61, Archives Napoléon.

${ }^{3}$ Almonte to Napoleon, 25 September 1862. AN: 400AP 61, Archives Napoléon.
} 
were liberal in their thinking and he did not believe there was much support for a monarchy, which would only be achieved after years of occupation by the French. As for Almonte, Lorencez thought Saligny had been too enthusiastic about supporting him, in the belief that he was under the protection of the Emperor, and now Almonte was accepting the role of chef-suprême instead of helping form a provisional government. He told Marshal Randon that he believed nothing would be possible with Almonte and Saligny in Mexico. ${ }^{4}$

Saligny on the other hand wrote again to General Rollin saying that the Mexican army was practically non existent, in spite of claims to the contrary. He added that their only serious enemies were their own military commanders who were fighting their own war against the politics of the Emperor, against his representative and against Almonte. Saligny claimed that General Lorencez, General Douai and Colonel Valazé spoke of each other in insulting terms in front of the soldiers and this was disastrous for morale and had to come to an end. He awaited anxiously the arrival of General Forey whom he and Almonte believed could have defeated the Mexican army easily with the forces already in Mexico. 5

Lorencez continued to support his own position and wrote to Marshal Randon in appreciation of an article he had placed in the Moniteur de l'Armée on 6 August refuting the accusations made against him in a letter that had been published in the Patrie on 4 August. Lorencez rebutted the criticisms made in the letter and justified his tactics since his arrival in Mexico hoping the Emperor did not believe the lies that had been written in it. The letter had presumably suggested that he should not have attacked Puebla but instead have by-passed it as advised by Almonte, for Lorencez argued:

Si je m'étais retiré de devant Puebla sans combattre, l'armée que je commandais eût été conspuée par l'opinion publique, j'aurais été immédiatement mis en retrait d'emploi, rappelé et perdu de réputation. Toujours on $\mathrm{m}$ 'aurait reproché d'avoir fait manquer le but de l'expédition du Mexique, en n'osant pas attaquer un ennemi qui n'existait pas, des obstacles qui n'existaient pas. Car c'était une opinion profondément enraciné en

\footnotetext{
${ }^{4}$ Lorencez to Randon, 22 July 1862. AMG: ${ }^{7} 1$.

5 Saligny to Rollin, 9 August 1862. AN: 400AP 62, Archives Napoléon.
} 
France, qu'on ne devait rencontrer au Mexique aucune résistance. Il est vrai que personne n'aurait pu dire sur quoi cette opinion était fondée. Pour prouver que l'expédition du Mexique ne présenterait aucun difficulté, on citait toujours celle que fit en 1847 et 1848 le Général Scott, dont personne n'avait lu la relation, car si cette campagne eût été connue on se fut convaincu du contraire de ce qu' on voulait prouver. ${ }^{6}$

We have seen already that Napoleon accepted Saligny's view of the situation in this respect because it was supported by others who either wrote directly to Napoleon or whose private letters were shown to him, and these included diplomats from Belgium and Prussia.

This practice by the Emperor of using other agents, both civilian and military, to obtain information about the situation in Mexico was and is widely criticised. Émile Ollivier was one of those critics, commenting that it created problems by undermining the authority of his commanders, and that while sometimes the results of this procedure were beneficial, often discipline was impaired, and the commander was disgraced. ${ }^{7}$ It also raises the question of how Napoleon was influenced. Randon had criticised the validity of accepting a civilian's judgement of an officer but perhaps Napoleon thought the unsolicited opinions of those who wrote to him were more disinterested than those of his Minister. Without more information one can only speculate. Lorencez was one of those to suffer and he was bitter that he had been judged and admonished by the Emperor on the basis of reports from people such as Saligny and a civilian, Vicomte de Lapierre, an aide-de-camp to Almonte, whom he described as a "coward and a spy". He wrote to Randon in anger at the reprimand he had been sent at the command of the Emperor in July. ${ }^{8}$

Yet was Napoleon wrong to use other sources to obtain as clear a picture as possible of the situation? Egon Corti said that he was like "many crowned heads before and since" who accepted information "from unauthorised sources for preference, so as to serve as a check upon the responsible persons to whom he ostensibly gave his

\footnotetext{
${ }^{6}$ Lorencez to Randon, 25 September 1862. AMG: $\mathrm{G}^{7} 1$.

${ }^{7}$ Émile Ollivier, L'Empire libéral, Vol. 6, pp. 451-452.

${ }^{8}$ Lorencez to Randon, 25 August 1862. AMG: ${ }^{7} 1$. See previous chapter.
} 
"confidence'."9 Corti commented, however, that the views of these "unofficial" parties were not necessarily reliable because they themselves were free from any responsibility and therefore were likely to judge things differently than they would if they did have responsibility. Whether or not the information obtained by Napoleon by these methods was more accurate or any less biased, it must nonetheless have served to broaden his understanding of what was happening in Mexico, even though it took some time for him to appreciate the deception of his agent. It was not until the fall of Puebla that he found that the views of his commanding officer and those of another source, Captain Gallifet, who wrote numerous letters to the Emperor, coincided and led to his realisation that it was his Minister, Saligny, and Almonte who had been misrepresenting his intentions and acting in complete contradiction to his policy. ${ }^{10}$ This leaves another question, however, which is as difficult to explain, and that is why Saligny behaved as he did and whether he was deliberately treacherous. This issue will be discussed further below.

Almonte's confidence in the position he occupied in the favour of Napoleon grew, and he believed that he and Saligny were the real masters of the situation in Mexico. He wrote to Napoleon that on his arrival at Vera Cruz, Forey apparently had taken several political steps already that would have offended the friends of the intervention. Almonte said that if this were true and Forey had taken action without waiting for the advice of Saligny and himself, he was likely to commit the same errors as his predecessors. He hoped that what he had heard was only rumour and that when Forey arrived at Orizaba they would be able to help him understand the true political situation of the country. All Forey had to do, he said, was to follow the path that they had cleared for him. He continued:

Le parti conservateur est organisé et se trouve avec nous, et tout ce qu'il y a à faire pour ne pas le décourager, c'est de nous laisser marcher jusqu'à Mexico de la même manière que nous l'avons fait jusqu'ici. ${ }^{11}$

\footnotetext{
${ }^{9}$ Egon Corti, Maximilian and Charlotte, p. 221.

${ }^{10}$ Taston Auguste, Marquis de Gallifet had been a military aide-de-camp to Napoleon in 1860 which would explain his familiarity with him. He became a general in 1870, Governor of Paris in 1880, and in 1899 was briefly Minister of War.

${ }^{11}$ Almonte to Napoleon, 8 October 1862. AN: 400AP 61, Archives Napoléon.
} 
This report must have startled Napoleon because aligning themselves with any party, let alone the Conservatives, was in complete opposition to the instructions he had given to each of his commanders. If the Conservative Party came to power again there would be fears among the population that the religious properties that had been sold by Juarez would be seized by the clergy and previous inequities continued. In addition Napoleon would be accused of supporting in Mexico the supremacy of the Catholic church when in his own country he had introduced freedom of religious cults. Napoleon had already given Forey very specific instructions on what to do on arrival in the capital, and he was to impress his ideas even more in the ensuing months.

On his arrival at Orizaba Forey began appealing to the moderates of the different parties, much to Almonte's annoyance. Forey reported to Randon that many of them had begun to return to the various towns occupied by the French, while he had received reports of other towns that had turned against Juarez and organised counter-guerrillas. He wrote that an influential liberal from Cordova said there was a change of ideas within the Liberal Party and before long the Congress itself was likely to overturn the Juarez government. On the other hand a letter from Mexico City informed him that some important Mexicans wanted to demonstrate in favour of Juarez and call for the expulsion of French residents in Mexico. Saligny, he said, who is "well informed of Mexican affairs" believed there was nothing serious in the rumours, however, and that the government would not dare take such steps even though Forey had information that some expulsions had already been carried out. To reassure the Mexican people Forey issued a proclamation saying that with the help of the French army they could establish a better government which would be able to develop the country and put an end to the anarchy and suffering that they had endured for so long. ${ }^{12}$ He believed it had made a favourable impression and that it would not be long before the people began to forget their differences and rally to the French in order to establish "a government capable of ensuring the prosperity, no less than the greatness of Mexico."13 This would of course

\footnotetext{
${ }^{12}$ Proclamation of General Forey to the Mexican people, 3 November 1862, A.D., Vol. 10, 1863, p. 76.

13 Forey to Randon, 9 November 1862 (r. 16 December 1862). AMG: $\mathrm{G}^{7} 1$.
} 
necessitate reciprocal concessions on the part of the extreme parties, but Forey was confident of such an outcome. He even believed that the clergy would resign themselves to the loss of their property and be prepared to make some concessions. To ensure this, though, he had asked Padre Miranda, who had arrived at Orizaba, to give a written undertaking not to oppose the French conciliatory politics but to support it completely.

Forey was also determined to re-establish good relations between the army and the French legation. Although he took decisive steps in this direction, within a month he was to be aware that Almonte and Saligny were pursuing a path in opposition to the instructions he had received from the Emperor, and that he was to be faced with similar difficulties to those of his predecessors. He regretted that Almonte was associated with them and he wrote to Napoleon that despite appearances Almonte was "cunning and a rogue who was certainly the representative of the reactionaries that the sane part of the population did not want." More and more he was gathering representatives of the retrograde party around him, Forey added, and it would become more difficult to get these people to compromise with the moderates of other parties who were the only ones that could help them establish a stable and honest government.

Forey told Napoleon he had heard that his own position was going to be attacked by someone returning to France, so he assured him that he believed what he was doing was exactly what he had advised him to do, which was "to rally all the honest men regardless of their opinions; to favour none of the extreme parties, leaning more towards the side of sound liberty and real progress, according to our great principles of ' 89 , than towards the reactionary side." 14 Forey's proclamation, made on his arrival in Mexico, had similarly highlighted the progressive politics of his own country when he appealed to the Mexicans:

Souvenez-vous que partout où flotte son drapeau, en Amérique comme en Europe, il représente la cause des peuples et de la civilisation. ${ }^{15}$

\footnotetext{
${ }^{14}$ Forey to Napoleon, 27 November 1862. AN: 400AP 62, Archives Napoléon.

15 Proclamation of General Forey to the Mexican people, 3 November 1862. A.D., Vol. 10, 1863, p. 76.
} 
As the campaign progressed, these elements of Napoleon's politics in France since his election as President in 1848, were to be reiterated as the blueprint for Mexico's new administration, both in Napoleon's instructions to his commanders and in his advice to Maximilian. Civilisation, to Napoleon, encompassed the principles of "equality before the law, civil and religious liberty, an upright administration, an equitable judicial procedure" amongst others. ${ }^{16}$ There were those, however, who claimed that Juarez and his government also upheld these very principles of liberty and progress, but he had lost credibility, rightly or wrongly, with Napoleon and was not to be negotiated with.

But this task of rallying the honest men, and that of maintaining good relations with Saligny was to prove almost impossible for Forey. He told Napoleon that it was very obvious that Saligny was not happy with being subordinated to him, and that Almonte did not like the idea of relinquishing the title of chef-suprême. Saligny was alleged to have sent a Spanish general to San Andrès to spread propaganda in favour of Almonte, and that this general had declared that in spite of General Forey's proclamations Almonte should still be regarded as chef suprême of the country. When confronted, Saligny and Almonte denied the truth of this accusation, saying Saligny had given the Spanish general a purely personal mission to undertake for him, while Almonte produced a declaration that he had been going to publish, dated a week earlier, relinquishing the role and title of chef suprême because of the arrival of General Forey. ${ }^{17}$

Forey was sceptical of the sincerity of both these men based on his experience with them so far. To General Fleury, aide-de-camp to Napoleon, he wrote that Saligny did not deserve the Emperor's confidence because he was disloyal, and lacked the uprightness of character one would expect from a person in his position. He had been unable to get on with Admiral Jurien, who was "honour itself", and Forey was convinced his problems with Lorencez were not the fault of the latter. Forey himself was not going to give Saligny any opportunity to make him the third victim, knowing how

\footnotetext{
16 Napoleon to Maximilian, 2 October 1863. Qouted by Egon Corti, Maximilian and Charlotte, p. 390.

${ }^{17}$ Forey to Napoleon, 25 January 1863. AN: 400AP 62, Archives Napoléon.
} 
distressed the Emperor would be at another breakdown within the command. ${ }^{18}$ Support for Forey's criticisms of Saligny was given by Gallifet who condemned Saligny for his habit of denouncing both Jurien and Lorencez in front of the officers, particularly as the departure of Lorencez was regretted by the army who regarded him with affection in spite of the defeat at Puebla. Almonte, he said, was not well regarded either because of his "inactivity". 19

Although the actions of Saligny and Almonte disturbed him greatly and made his task extremely difficult, Forey's greatest concern was how he was going to get the people of Mexico to vote, by universal suffrage, on the form of government they wanted This issue of Napoleon's intentions regarding a vote by universal suffrage has given rise to perhaps even more debate than other aspects of the campaign. The difficulties, Forey wrote to Napoleon, were insurmountable and the nature of the Indians was such that they should not be consulted at all. In France, he said, it was easy, but in Mexico there was no centralisation, each province being independent of the capital in reality, if not legally; there was no regular administration or rapid means of communication; and the population consisted of one or two million Mexicans, and six or seven million Indians who had no bond with the government whose form mattered little to them. He continued with his description of the Indians:

d'une ignorance absolue, espèce de bêtes brutes vivant presque à l'état sauvage et chez qui n'existe même pas d'état civil, je me demande comment il sera possible de receuillir les votes; et d'un autre côté, à supposer que l'on ne tienne aucun comte de cette partie de la population qui est cependant la plus considérable de beaucoup et de beaucoup enfin la plus intéressante parce qu'elle est laborieuse, de mœurs douces et très facile à gouverner; l'autre partie se composant de la masse des mexicains qui tremblent devant quelques centaines de mille d'individus audacieux ne vivant que d'exactions, de rapines, de meurtres et qui dirigeront les votes des premiers par la terreur qu'ils inspirent, je me demande encore si la résultat de ce vote pourra être considéré comme l'expression de la volonté nationale. La difficulté sera grande, n'en doutez pas, Sire, enfin j'espère que vos conseils en cette circonstances ne me feront pas défaut 20

\footnotetext{
18 Forey to Fleury, 25 January 1863. AN: 400AP62, Archives Napoléon.

${ }^{19}$ Gallifet to Napoleon, 9 February 1863. AN: 400AP 62, Archives Napoléon.

${ }^{20}$ Forey to Napoleon, 11 January 1863. AN: 400AP 62, Archives Napoléon.
} 
To a certain extent Forey's assessment of the population of Mexico was correct. The Indians still formed the majority of the population but they had occupied a position of inferiority for centuries under the Spanish occupation. The Creoles, Spanish people born in Mexico, considered coloured races inferior and that the Indians were "by nature, lazy, drunken and stupid". If they appeared this way it was not because it was their nature. It was rather the result of oppression ever since the conquest by Cortez. They had not been educated by the Spanish and were mostly kept in farming and labouring positions before independence opened opportunities, at least for education. Juarez was one to benefit from this and qualified as a lawyer. But the new race, the mestizos, who were a result of Creole and Indian intermarriage, became the Mexicans, the revolutionaries who resented the Creoles and were not accepted as Indians either. ${ }^{21}$ The Indians had generally been excluded from involvement in the choice of government so Forey was correct in his realisation that this task would be new to them.

It was only in response to this letter that Napoleon suggested that if necessary Forey should conduct "a kind of universal suffrage, or even a vote of a Congress named by the traditional and usual revolutionary means used in Mexico".22 When commenting on this advice of Napoleon's, Ollivier failed to show that it was in response to the letter Forey had written in January, although he may not have known of it, and he added fuel to the arguments of later analysts that Napoleon had no intention of conducting a genuine vote by universal suffrage. Ollivier also commented on a later letter from Napoleon which suggested Forey consult the nation in the way he thought most suitable, and he claimed Napoleon was telling Forey to arrange matters to give him "something that resembled a vote of the nation".

This view was supported by Corti who said that Napoleon's instructions to Forey implied

it must appear as if the Mexicans were being allowed a free choice, while in reality the plan long since hatched in Paris was to be carried out in its

\footnotetext{
${ }^{21}$ Henry Banford Parkes, The History of Mexico (London, 1962, (c) 1960), pp. 98-102.

${ }^{22}$ Napoleon to Forey, 14 February 1863. Quoted by Émile Ollivier, L'Empire Libéral, Vol. 6, pp. 438-439
} 
entirety: namely, the monarchy and the Archduke Ferdinand Max!

Napoleon attached the greatest importance to 'keeping up appearances'.

The world must believe in all seriousness that it was far from being the

liberal Napoleon's intention to impose an alien domination upon the

Mexicans. And so everything must be skilfully led up to in a manner

befitting the Emperor's plans. ${ }^{23}$

To support his view Corti referred only to the content of Napoleon's letter of 14

February 1863, as had Ollivier, although he did not mention the date of the letter. He did not refer to Forey's letter of 11 January 1863 which had prompted this remark by

Napoleon, but it is quite possible he did not know of this letter, either. His source for

the former letter was Gaulot, but he did not refer to the two other letters quoted by Gaulot

at the same reference, which both said in similar terms:

La seule politique à suivre est de marcher sur Mexico, d'y installer un gouvernement des hommes les plus honorables que vous choisirez vousmême, et ensuite, de faire voter par le suffrage universel, le peuple mexicain, sur la forme du gouvernment à établir. ${ }^{24}$

Nor did Corti make mention of the following comments made by Gaulot, based on the notes of Ernest Louet, the chief paymaster in Mexico, to explain this apparent change in Napoleon's instructions, perhaps because Corti decided that Napoleon had intended all along to conduct "a kind of universal suffrage". Gaulot wrote, and is worth quoting at length:

Issu du suffrage universel, Napoleon III se montrait ici fidèle à son origine en recommandant d'en appeler au suffrage universel. S'il ajoutait un correctif en disant 'une espèce de suffrage universel', il y avait là, non point un abandon du principe, mais une concession faite à des impossibilités matérielles. Les registres de l'état civil étaient fort mal tenus au Mexique, par conséquent, des difficultés insurmontables s'opposaient à ce que l'on fabriquât une liste générale des électeurs. En outre, on n'occupait encore qu'une partie du pays. Mais l'Empereur répète sans cesse le mot de nation: c'était donc la nation qu'il fallait consulter et non point seulement quelques notabilités choisies uniquement dans la capitale.

\footnotetext{
${ }^{23}$ Egon Corti, Maximilian and Charlotte, p. 221. He uses as the basis for these assumptions the letters from Napoleon to Forey refered to by Paul Gaulot in Vol. 1, p. 132. The letters quoted on this page were dated 1 November 1862, 17 December 1862 and 14 February 1863, but it is only the content of the last of these that Corti has made use of without actually mentioning the date.

${ }^{24}$ Napoleon to Forey, 17 December 1862. Quoted by Paul Gaulot L'Expédition du Mexique, Vol. 1, p.132. Paul Gaulot authenticates his sources as original letters that were collected by Emest Louet from people such as Marshal Bazaine who had confidential letters from Napoleon, Randon and Maximilian among others. He also obtained material from Vienna, Brussels, Trieste and Miramar. These were placed in Gaulot's care when Louet died.
} 
De plus, la pensée de l'Empereur était bien claire: il ne voulait pas de précipitation, pas de vote 'escamoté' à quelques individualités, groupées sous un nom pompeux, et réunis à la hâte en quelques jours. Il tenait à ce qu'un gouvernement provisoire commençât par rendre au peuple mexicain l'apparence de son autonomie et de la liberté; puis, à l'abri de cet ordre de choses, on devait faire peu à peu pénétrer dans le pays entier ses intentions, c'est-à-dire son désir de voir la nation mexicaine recouvrer son indépendance sous un gouvernement qu'elle choisirait elle-même.

Opinions similar to Corti's, however, have been generally more widely shared by both contemporaries and historians, but as I will show, there is more to support Paul Gaulot's views than there is to support Corti.

While Forey was pondering these difficulties his delay in reaching Mexico City began to be questioned in Paris, although Napoleon himself was quite understanding of the problems caused by lack of supplies or equipment. Marshal Randon, however, was not so understanding and strongly criticised Forey who wrote to Napoleon that Randon did not seem to appreciate the difficulties that they were encountering. Forey was supported by Gallifet who wrote that he had many difficulties to surmount and that all sections of the army complained of the "parsimony" with which Saligny had estimated the equipment and provisions they would need. ${ }^{25}$ But he also wrote that the other officers were critical of Forey's slow progress towards Puebla although, he assured Napoleon, they still had confidence in him. While they recognised in principle that it was better not to attack the town until he had all he needed to do so, they disagreed with his prolonged stay at Orizaba, saying he could have made better use of the transport he did have and would have been able to get provisions along the way. Tactically, Gallifet said, it would have been better to move on to towns such as Amazoc which were closer to Puebla, to await the extra equipment. ${ }^{26}$

Napoleon was not concerned at these strategic delays, but when he heard Forey had stopped again a few days from Orizaba to wait a further five days for money to arrive to pay the soldiers, he was incensed. The paymaster had apparently been concerned

\footnotetext{
${ }^{25}$ Gallifet to Napoleon, 9 February 1863. AN: 400AP 62, Archives Napoléon.

${ }^{26}$ Gallifet to Napoleon, 21 February 1863. AN: 400AP 62, Archives Napoléon
} 
there was not enough money left to pay for essential services or to pay the Mexicans who were helping with the transport, and it was the fear of seeing them abandon the convoys that had made Forey decide to wait for the arrival of extra money from Havana. But Napoleon wrote:

J'ai reçu votre dernière lettre qui va jusqu'au 28 février. C'est la première, je l'avoue, qui m'ait fait éprouver une grande déception. Je conçois qu'un général d'armée se trouve entravé dans ses opérations par le défaut de vivier ou de munitions, mais retarder sa marche devant l'ennemi pour attendre un convoi d'argent, c'est ce qui me passe et que je ne puis admettre. J'espère que les premiers courriers qui m'arriveront m'apporteront des nouvelles qui me feront oublier ce fâcheux contre temps. ${ }^{27}$

The remainder of this letter was devoted to detailed instructions on what Forey was to do after his arrival in the capital, instructions that were to be modified by Forey under the influence of Almonte and Saligny. Forey was instructed to form a provisional government composed of the most commendable men, but to appoint their own $\mathrm{M}$. Budin as provisional administrator of finances so that they could maintain control of the financial resources of the country to help "introduce the politics of order and integrity." The provisional government could be assisted by a junta of notables composed as far as possible of men chosen by Forey from the "rich classes" of the country, Napoleon told him. While this provisional government was to "function nominally with independence" it was to remain in fact under Forey's command. This was to allow time for the people to become confident that France really intended to help them and did not intend to impose a government they did not want.

Napoleon outlined a number of tasks that the provisional government was to be directed to undertake, but the provisional government was in many respects to take action almost diametrically opposed to Napoleon's ideas. Their first task would be to disband the reactionary or other groups of soldiers and organise an auxiliary army of the best elements of the Mexican troops, the first step in Napoleon's plan to reduce French involvement. The people were to be assured that church and state property bought

\footnotetext{
${ }^{27}$ Napoleon to Forey, 14 April 1863. AN: 400AP 62, Archives Napoléon.
} 
legitimately would not be taken from those who had bought it, and while the Catholic religion would be protected, freedom of other religions would be established. But when the provisional government began courting the Conservative Party which was heavily influenced by the clergy, this became another promise of Napoleon's that was in danger of being broken.

This letter of Napoleon's is an important document which reveals not only Napoleon's ideas on the formation of the government but also his intentions to improve the administrative and social aspects of the country, which included developing the roads and railways and improving the cleanliness of the waterways. Forey was directed to deliver a manifesto to the people describing these proposed actions which were also intended to remove the exacting taxes and other burdens on the poorer classes. Napoleon concluded these instructions with the following direction:

Lorsque ses mesures et d'autres semblables auront pu être prises et qu'on aura répandu dans le pays mes intentions, et fait connaître le but de l'intervention, on pourra alors consulter la nation, de la manière que vous jugerez le plus convenable.

This latter instruction was referred to above and used by Ollivier to shed doubt on Napoleon's intentions relating to the system of voting. But, seen as a response to Forey's request for advice after he had described the difficulties he foresaw in this regard, it does not imply a reversal of Napoleon's intention to consult the nation on its choice of government. Nor does it reveal that he had never intended to consult the people.

When Puebla finally fell in May 1863 Napoleon wrote to Forey and congratulated him and the army on their achievement, revealing his obvious respect for Forey and his appreciation of the difficulties that had confronted him. He recognised that the enemy had been far more stubborn than he had been led to believe, and that as a result the army must have felt they had been misled about his intentions in Mexico. He concluded his letter as follows, to reassure them:

Je déplore amèrement la perte probable de tant de braves, mais j'ai la consolante pensée que leur mort n'a été inutile ni aux intérêts, ni à l'honneur 
de la France, ni à la civilisation. Notre but, vous le savez, n'est pas d'imposer aux Mexicains un gouvernement contre leur gré, ni de faire servir nos succès au triomphe d'un parti quelconque. Je désire que le Mexique renaisse à une vie nouvelle et que bientôt régenéré par un gouvernement fondé sur la volonté nationale, sur les principes d'ordre et de progrès, sur le respect du droit des gens, il reconnaisse par des relations amicales, devoir à la France son repos et sa prospérité. ${ }^{28}$

His optimism though was not to be rewarded by the events that were to occur after the occupation of Mexico City. But at the same time as he wrote this letter he ordered the recall of Saligny realising at last, apparently, that it was he who had misled him over the difficulty of the situation in Mexico.

In the meantime, Saligny and Almonte continued directing events in their conviction that they alone knew and understood Mexico and that they were fulfilling the Emperor's wishes. Almonte, in his confidence in his relationship with the Emperor, told him that if Forey followed his advice he could pursue Juarez, who had abandoned the capital in the face of the imminent arrival of the French, and within two months he and his followers would have left the republic. He then proceeded to say how he regretted that the direction of political affairs was no longer in Saligny's hands, and he offered Napoleon advice on the problems that would result from Forey's continued direction, and on how the campaign should henceforth be directed:

... tant qu'il sera subalterné au Général en Chef, la pensée de Votre Majesté restera exposée à être souvent contrariée à cause du manque d'intelligence du Général et du peu de connaissances qu'il a des affaires et des hommes de mon pauvre pays. Je crois, sire, que tout pourrait se remédier politique [sic] et militairement parlant, et Votre Majesté pourrait se rassurer sur la marche favorable des affaires de l'entreprise, si elle se décidait à nommer le général Bazaine, Général en Chef du Corps Expéditionnaire, et $M$. de Saligny, directeur exclusive de la politique. Votre Majesté pourrait accorder pour cela au Général Forey la recompense qu'elle jugerait convenable et il rentrerait en France en laissant les choses ici prendre leur marche naturelle, ${ }^{29}$

\footnotetext{
${ }^{28}$ Napoleon to Forey, 12 June 1863. AN: 400AP 42, Archives Napoléon. This letter arrived in Mexico at the end of July 1863

${ }^{29}$ Almonte to Napoleon, 2 June 1863. AN: 400AP 61, Archives Napoléon.
} 
There is no evidence of Napoleon's reaction to what seems very impertinent advice, but it is probable that it was not favourable, as might be judged from his reaction to Almonte's suggestion later that same month of a reward for Saligny.

Saligny and Almonte wasted no time in preventing Forey from using his own initiative after the occupation of Mexico City. Saligny wrote to advise him on the method to use to convoke a provisional government and of whom it should be composed, presenting him with a manifesto, already prepared for his signature, to advise the people of the procedure that was to be adopted. He suggested that the "triumphal march" of the army into the capital and their rapturous greeting by the people was sufficient proof of "the sentiments of the vast majority towards the liberators of Mexico". The perfect order which had persisted in the capital since the flight of the defeated government indicated without doubt that the people were ready, with France's help, to begin the regeneration of their country, therefore they could not afford to disappoint the people or fail to fulfil the benevolent thoughts of the Emperor, he added. With this in mind, he said:

je viens vous apporter la fruit de l'étude approfondie que j'ai faite sur la situation du pays, de ses besoins, et des mesures que me paraissent propres à remplir le but que la France se propose, c'est à dire la réorganisation des pouvoirs publics, afin que la nation rendue à elle-même, puisse dans toute son indépendance, et par l'organe de ses citoyens les plus intelligents et les plus considérables, faire connaître la forme définitive du gouvernement qui lui conviendra le mieux. ${ }^{30}$

It can be seen from this that Saligny proposed a limited suffrage and he proceeded to justify this proposal. He advised Forey that it was not possible to convoke a general congress to decide the important questions facing the country at the moment, because the state of the country would not permit the representatives of the large cities and distant provinces to respond to the appeal to them. Neither could Saligny consider including the Indian mass "in this important act of the Mexican nation". "This population," he said, "so worthy of interest in many respects, until now has been kept outside public affairs, so would not understand the gravity or the consequences of a vote". Having dismissed

\footnotetext{
${ }^{30}$ Saligny to Forey, 16 June 1863, reproduced in the manuscript, Journal de la Campagne du Mexique, de la Hayrie. AMG: MS 851.
} 
these sections of the population from the suffrage Saligny persuaded Forey that

representatives from Mexico City were sufficient to obtain the vote of the nation:

La capitale, où il n'est pas un seul état qui ne se trouve représenté par des citoyens illustres, compte près de 200,000 habitants. Elle renferme un nombre considérable d'intelligences, d'élite habitué à la vie publique et aux affaires politiques. C'est d'ailleurs dans la capitale qu'a pesé la plus lourdement le gouvernement qui vient de tomber. A cette grande population doit appartenir par conséquent, dans les circonstances actuelles, le soin de faire connaître le meilleur moyen de fermer l'ère des révolutions périodiques dont le Mexique est le théâtre, depuis près d'un demi-siècle. ${ }^{31}$

Having cleared the path for a limited suffrage, Saligny proposed to Forey that he decide that a junta composed of thirty five citizens "chosen from among the most honourable citizens" of Mexico City be charged with a list of powers which he proceeded to elaborate. Three Mexican citizens should be chosen to have executive power while a further 215 be elected to form an assembly of notables to decide on the "definitive form of the government".

This letter from Saligny was very obviously influenced by an undated lengthy note written by Almonte, which would seem to have been written after the taking of Puebla. In it he described in detail the system of limited suffrage that he claimed had been used by successive governments and which had been accepted by both the Mexican people and other governments. ${ }^{32}$ The similarities between this document and Saligny's letter to Forey are striking, and point to the influence that Almonte had. Whether or not Forey saw Almonte's note he accepted Saligny's advice and nominated the committee of thirty five notables. At the end of June he forwarded to Napoleon the list of notables who had been chosen in such a way that they would represent as far as possible the universal suffrage which, according to Forey, had been impractical for a long time but was especially so now when the defeated government still instilled fear in the honest part of the population. 33

\footnotetext{
31 Ibid

${ }^{32}$ Note signed by Almonte, undated and with no addressee. However, as it is among Almonte's letters to Napoleon in the Archives Napoléon in the Archives Nationales it is highly probable that it was included with one of his letters of advice to the Emperor. The heading states: "Considérations sur les mesures qu'il y aurait à prendre, dès l'occupation de Mexico, par l'armée française, pour établir dans le pays une autorité gouvernementale préparatoire." AN: 400AP 61, Archives Napoléon.

${ }^{33}$ Forey to Napoleon, 30 June 1863. AN: 400AP 62, Archives Napoléon.
} 
Napoleon was to be greatly disturbed by the next letters that arrived from Mexico. Before the Assembly met to vote on the form of government, Forey remarked to Napoleon that he was certain they would vote for a monarchy and he was ready to pronounce the name of the Archduke Maximilian. Almonte also pre-empted the work of the Assembly by writing to Napoleon, five or six days before the Assembly was to meet, that he would receive by the next steam boat its declaration for the monarchy and the Archduke. Having announced this fait accompli Almonte then told Napoleon how the venture should be directed from then on:

Pour achever l'œuvre, nous désirions que Votre Majesté nous laissa ici comme Commandant en Chef le Général Bazaine et comme directeur exclusive [sic] de la politique M. de Saligny; alors tout marchera à merveille.

Je vous prie, Sire, de ne pas oublier que Votre Majesté a offert indirectement à Saligny de le faire Senateur. Il est temps, je crois, Sire, de le recompenser. ${ }^{34}$

A remark in Napoleon's handwriting beside this last comment of Almonte's makes it quite clear that Almonte was being over presumptuous in his relations with the Emperor, who wrote: "erreur, ni directement ni indirectement". It is apparent from this that Napoleon had no intention of rewarding Saligny for his efforts in Mexico. However, in one respect Napoleon did do what Almonte suggested and that was to decide to put General Bazaine in charge of the expedition and recall Forey. Still, it is doubtful the decision to appoint Bazaine was the result of Almonte's advice for it was probably the most practical solution, given the decision to change the command was taken so quickly.

One of the most puzzling dilemmas of the Mexican campaign has been the place that Saligny seemed to occupy in relation to Napoleon. Although historians have acknowledged that perhaps he gave Napoleon misleading information most have decided that ultimately his determination to see a monarchy established in Mexico was the fixed intention of the Emperor also. These conclusions, however, have been based on a limited number of documents even though many of them that Corti, for example, used have actually shown that Napoleon insisted the people had to decide the form of

\footnotetext{
${ }^{34}$ Almonte to Napoleon, 26 June 1863. AN: 400AP 61, Archives Napoléon.
} 
government. Much of Corti's argument rested on a letter from Metternich to his Foreign Minister in Vienna in November 1861. He wrote that Jurien had been given secret instructions

d'amener le parti monarchique à rassembler une espèce de constituante formée par les représentants, non par les députés, de toutes les provinces du Mexique et de lui faire exprimer des vœux aux puissances alliées. ${ }^{35}$

Corti was the first to make use of this information, but others also have used Metternich's letter as the proof they needed to show that Napoleon was determined to impose a monarchy on Mexico. Metternich, however, had expressed surprise at Napoleon's suggestion of a limited suffrage to determine the wishes of the Mexican people but Napoleon said that selection by universal suffrage would not be appropriate for an Austrian Prince. However, as this is the only record that Napoleon entertained the idea of a limited suffrage it is difficult to know how much validity should be given to Metternich's report of his conversation with Napoleon.

Another aspect of the dilemma for historians has been that the opinions of Saligny were accepted by Napoleon over those of his commanders for more than a year, but the probable reasons for this have been explained above, perhaps as best they can be. However, when Puebla finally fell to the French in May 1863 Napoleon realised that it was Saligny's information that had led him to believe the campaign would not be difficult and Juarez would be easily overthrown. Forey's and Almonte's letters would have reached Paris at the end of July and Forey's actions under the guidance of Saligny and Almonte made Napoleon realise how his instructions had been entirely changed or misconstrued. The decision to recall Forey seems to have been taken after the receipt of these letters and the fact that instructions to Bazaine, who was to take over command, were sent on 17 August supports this assumption.

But it is not just an assumption, because the majority of the correspondence from Forey and Almonte, and some from Lorencez that I have referred to has not been used by

35 Metternich to Count Rechberg, 16 November 1861. Henry Salomon, "Le Prince Richard de Mettemich ", p. 525. 
historians of the Mexican expedition before. By using this new material I have shown that there is little doubt that Napoleon intended that the Mexican people should decide the form of government they wanted and that he wished this to be done by means of universal suffrage. I have also shown that the decision to modify this was done by Forey under the powerful influence of Almonte and Saligny. If Forey believed he was doing what the Emperor wanted there would be little reason for him to justify his actions as he did in his letter of 30 June 1863 , or to complain of the problems he foresaw in carrying out such a vote, as he did in that of 18 January. ${ }^{36}$ There would also be little reason for Napoleon to recall both Forey and Saligny if they were in fact carrying out his instructions satisfactorily.

This then raises the question of how and why Saligny believed he was doing what the Emperor wanted. Everything written by the Emperor refutes any claims by Saligny that he intended a monarchy be installed or that there was to be "a semblance of a universal vote" conducted. And there seemed to be nobody in Mexico, except Almonte, who accepted or supported Saligny's opinions. The news of his recall was greeted in Mexico with both delight and relief by the French army and the Mexicans, none of whom had any respect or liking for him. General du Barail described the arrival of this news as follows:

... de toutes les nouvelles apportées par le courrier de France, ce ne fut point la moins agréable à l'armée, qui considérait en M. de Saligny l'auteur de toutes les fautes commises, le bourreau de l'amiral Jurien de la Gravière et du général de Lorencez, le fauteur de la politique réactionnaire et cléricale, opposée au goût des Mexicains et même aux institutions politiques des Français, et enfin le principal obstacle à la pacification désirée. ${ }^{37}$

This is a stark contrast to Saligny's view of the role he played for he is reported to have been convinced that the Emperor and his government were looking for a pretext for a military occupation of the country and that he had done all he could to help realise that aim. To Emest Louet he said some time later:

\footnotetext{
${ }^{36}$ These documents, which included 36 letters from Forey, 29 from Almonte, 83 from Bazaine and a number from Lorencez, were found in AN: 400AP61-63, Archives Napoléon, which were not used as a source by previous historians of this campaign.

${ }^{37}$ Général du Barail, Mes Souvenirs, 1851-1864, 2 Vols (Paris 1898),.Vol. 2, p. 478. General du Barail was a Colonel in the expeditionary forces in Mexico.
} 
Mon seul mérite est d'avoir deviné l'intention de l'Empereur

d'intervenir au Mexique, et d'avoir rendu l'intervention nécessaire. ${ }^{38}$

If Saligny was correct in his assumption, then Napoleon would have had no reason to order his recall. Napoleon's decision to do this and to continue to press for the opinion of all the people regarding the form of government after Saligny's recall seems to deny any validity to this claim.

Was Saligny deliberately treacherous then, and if so, why? From his comment to Ernest Louet seen above, which was made some time after the Mexican campaign was concluded, it would appear that he was entirely convinced that he was doing what the Emperor wanted. This is difficult to accept because Saligny had arrived in Mexico in December 1860 with instructions to conciliate with the two governments claiming authority to help achieve a single, stable government. It is highly unlikely that at that time Napoleon would have advised him personally that he intended to intervene to impose a monarchy. There is also no record of any correspondence between Napoleon and Saligny, and all his instructions were conveyed by Thouvenel and have been seen to be far more circumspect than Saligny claimed. But most importantly, in his conversation with Louet, he said that he had "correctly guessed (deviné) the Emperor's intention to intervene in Mexico", which indicates he had no direct communication that this was so. It is only possible to speculate on the reason Saligny thought he was doing something to please the Emperor. Perhaps it was to gain recognition from the Emperor in a bid to enhance his nondescript diplomatic career. It would seem, though, that his unscrupulous behaviour and disagreeable character may have been the reason his career had foundered before, and once again he was to live in oblivion. After Maximilian's death Saligny wrote to the Emperor saying how he believed the intervention had been justified and he requested an audience with him. This was denied. ${ }^{39}$

\footnotetext{
${ }^{38}$ Paul Gaulot, L'Expédition du Mexique, Vol. 1, p. 30.

${ }^{39}$ Saligny to Napoleon (n.d.). AN: ABXIX 172.
} 
Whatever Saligny's motivation, his and Almonte's influence was bringing to fruition the plans they attributed to Napoleon. The predictions made by Almonte and Forey proved correct and all but two of the Assembly of Notables voted in favour of a monarchy and to offer the crown to Maximilian. They also decided to nominate a Regency of three to rule Mexico until Maximilian's arrival, the three being Almonte, a General Salas, and the Archbishop Labastida who was then in Rome but to be represented by the Bishop of Mexico City until his return. ${ }^{40}$ Forey wrote in support of the election of Maximilian saying that it was for the best, as the only way to end the era of revolutions was to have a foreign prince to rule the country, which, if he was not mistaken was the thinking of the Emperor. ${ }^{41}$

Forey had good reason to support the idea of a foreign prince as ruler because the difficulties that continued with the opposing factions, even after the election of the Regency, were far too testing for him and he declared to Drouyn de Lhays that the role of diplomat in such a country as Mexico was beyond him. ${ }^{42}$ Within a month he was writing to Randon expressing his eamest hope that Maximilian arrive quickly to take over the pacification of the country. There were, he said, only two parties, the Liberals and the Conservatives, neither one better than the other, and to speak to them of moderation, justice or conciliation was to waste one's time. He continued:

Ils ne comprennent pas ce langage parce qu'il n'existe pas le parti modéré, de parti vraiment national. Chacun ne veut le retour au pouvoir de ses partisans que pour pouvoir opprimer la faction opposée. Ainsi, cédant à de regrettables influences, la régence se laisse entrainer dans une voie réactionnaire que je ne puis tolérer, et décrète les mesures auxquelles je dois m'opposer. 43

It was the combination of all these difficulties that convinced Forey that a monarchy was the best solution for Mexico, with a foreigner unaligned with any of the factions to lead

\footnotetext{
40 Salas was the most senior of Mexican generals, aged seventy two, who had been an interim president of the Republic for a month in 1846. According to Paul Gaulot he brought to the government no other strength than his worthiness, and could offer noching but his signature. Paul Gaulot, L'Expédition du Mexique, Vol. 1, p. 138).

${ }^{41}$ Forey to Drouyn de Lhuys, the new Minister of Foreign Affairs, 25 July 1863. AN: 400AP 62, Archives Napoléon.

42 Ibid.

${ }^{43}$ Forey to Randon, 10 August 1863 . AMG: $\mathrm{G}^{7} 1$.
} 
it. He told Napoleon that it was only those who were opposed to the Regency who favoured a republic and they were by far in the minority. ${ }^{44}$

Napoleon in the meantime was determined to consult the people as a whole, and looked on the vote of the Regency as purely an indication of the will of the people. He had been following events with a cautious optimism which was reflected in his correspondence with Maximilian. After the fall of Puebla he advised Maximilian that there were "still many obstacles to be overcome", while at the news of Maximilian's proclamation as Emperor by the provisional government he wrote: "I am glad of this first result, I hope that the whole of Mexico will soon follow the example of the capital and summon Your Imperial Highness to regenerate her."45 Maximilian replied to this latter remark by expressing his admiration for the fact that Napoleon had not "abandoned [his] original design of calling, not only upon the notables of the capital, but upon the whole country, to declare themselves with regard to its destiny". ${ }^{46}$ In his next letter to Maximilian accompanying a copy of the resolution of the Assembly of Notables at Mexico City and Vera Cruz, Napoleon said: "I am happy to see that Your Imperial Highness's name is rallying to it a great number of adherents; however, in order that the will of the Mexicans should be more manifest, I should like an appeal made to the people to ratify the choice of the notables by their votes." 47 To this Maximilian replied:

Your intention, Sir, of appealing to the whole nation to ratify the act of these two great cities is an unequivocal proof that Your Majesty intends, in your exalted wisdom, to establish a firm and lasting structure in Mexico. The expression of the will of the nation will give the Government the conviction that the intention is to establish a strong moral force both at home and in foreign relations. ${ }^{48}$

In a later letter Maximilian expressed the fact that he disagreed entirely with Almonte's suggestion that the vote of the notables of Mexico City was an "expression of the desires of the nation: Your Majesty, like myself, has from the outset seen in it no more than a

\footnotetext{
44 Forey to Napoleon, 16 August 1863. AN: 400AP 62, Archives Napoléon.

45 Napoleon to Maximilian, 21 June 1863, and Telegram, Napoleon to Maximilian, 8 August 1863. Quoted by Egon Corti, Maximilian and Charlotte, pp. 376-377.

${ }^{46}$ Maximilian to Napoleon, 10 August 1863. Ibid. p. 378.

47 Napoleon to Maximilian, 15 August 1863. lbid. p. 379

${ }^{48}$ Maximilian to Napoleon, 26 August 1863. Ibid. p. 380.
} 
first result.[sic], in itself very happy, but which must be completed by the adhesion of the whole country, or, at least, of the large majority of provinces composing it". 49

Although Napoleon would have preferred that the choice of the desired form of government had been put directly to the people, he was now faced with a train of events he could do little to stop. What he could do was to ensure that the wishes of the Assembly were at least submitted to the people for ratification or rejection. Instructions in this vein were sent to the new commander, General Bazaine, by Drouyn de Lhuys well before the arrival of the above letter from Maximilian. They stated that the Assembly's role now, as a result of their own vote, was to recommend to the people the adoption of a monarchical institution and offer the name of a prince to their suffrage. He continued:

Il appartient maintenant au Gouvernement provisoire de recueillir ces suffrages de manière qu'il ne puisse planer aucun doute sur l'expression de la volonté du pays. Je n'ai pas à vous indiquer le mode à adopter pour que ce résultat indispensable soit complètement atteint: c'est dans les institutions et les habitudes locales qu'il faut le chercher. Soit que les municipalités doivent être appelées à se prononcer dans les diverses provinces à mesure qu'elles auront reconquis la disposition d'elles-mêmes, ou que les listes soient ouvertes par leurs soins pour recueillir les votes, le mode le meilleur sera celui qui assurera la plus large manifestation des vœux des populations dans les meilleurs conditions d'indépendance et de sincérité. L'Empereur, Général, recommande particulièrement ce point essentiel à toute votre attention. 50

From this there seems little doubt of Napoleon's sincerity in wanting as wide a consultation as possible, but he recognised that the means of achieving that was now out of his hands.

Was Napoleon naïve in his determination to obtain the will of the people as he had done in France to inaugurate his own empire? Perhaps he can be justly accused for not understanding the country, its traditions and culture well enough, but he nevertheless refused to dismiss out of hand a section of the population, notably the Indians, from being involved in the vote. Regardless of his commanders' opinions, he seemed to adhere to his belief that all people were equal, regardless of race. Although Saligny and

\footnotetext{
${ }^{49}$ Maximilian to Napoleon, 12 September 1863. Ibid. p.382.

${ }^{50}$ Drouyn de Lhuys to Bazaine, 17 August 1863. A.D., Vol. 12, 1863, p. 289.
} 
Almonte may have been correct in their descriptions of the traditional methods of choosing a government in Mexico, it was precisely these traditions that Napoleon hoped to change in order to bring to an end the decades of revolution and pronunciamentos that had brought Mexico to its present state of anarchy and poverty. This was why he was so disturbed by the action taken by the Assembly of Notables and its appointment of a Regency which began to take more decisions in opposition to his clearly expressed aims and ideals.

The reality of determining the voice of the people, however, was to be far more difficult than Napoleon had expected. The problems associated with conducting such a suffrage in this country of far flung provinces with appalling means of communication between them, were recorded in the memoirs of General du Barail. The French army was charged with the task of determining the wishes of the people and du Barail wrote cynically of the attempt to do this:

Nous allions faire une campagne électorale, dont le succès ne pouvait pas être douteux, car ces populations, habituées à voter aujourd'hui pour Pierre, demain pour Paul, auraient acclamé le diable ou le Grand Turc, si nous avions présenté leur candidature au bout de nos sabres et de nos bä̈onettes. Nous allions donc transporter à la fois des urnes et des canons, et faire le double office de soldats et de courtiers électoraux. ${ }^{51}$

Whatever du Barail's views of their orders, Napoleon was unlikely to commit the army to such a task if he were not genuine in his intentions.

This was not the only problem confronting the Emperor, as the relationship of the Regency with the clergy was becoming particularly alarming. In August Forey wrote to both Napoleon and Randon that he was hoping for the early arrival of Maximilian to pacify the country and to end the disastrous management by the Regency. Not only did they want to compel all dissidents to proclaim in writing their adhesion to the Provisional government under pain of arrest and imprisonment, but most importantly, Forey said, they refused to reassure the new owners of national and church properties, and this was leading those legitimate owners to mistrust Napoleon's intentions. Forey concluded: "If

${ }^{51}$ Général du Barail, Mes Souvenirs, Vol. 2, pp. 483-484. 
it places itself under clerical domination, as it seems to intend, it will be following a reactionary policy, and it will not rally round it moderate men who are truly but simply religious."52 Some of their early actions included refusing the Last Sacraments and a Christian burial to those who would not return property they had bought; issuing an ordinance forbidding work on Sundays; and decreeing that everyone had to go down on their knees when they encountered the Holy Sacrament, and to remain there until it had disappeared and the bells could no longer be heard. Forey said it was like a return to the Inquisition. ${ }^{53}$ Napoleon's reaction to this news is evident in a letter to Maximilian telling him of these latest developments:

I feel it my duty to communicate to Your Imperial Highness the enclosed extracts from a letter which I have just received from Marshal Forey. Unless a perfectly clear declaration is made with regard to the ratification of the sales of national property, I regard the establishment of a monarchy in Mexico as impossible. ${ }^{54}$

The issue of the position of the clergy was to be a problem that was to cause Maximilian difficulties also, partly because of the long history of their financial power and corruption, but also because Maximilian failed to discuss the position of the clergy with the Pope before his departure for Mexico. The immense riches that the Mexican clergy possessed had been accumulated from the time of Fernand Cortez, who had distributed a large part of the country's wealth to them. This wealth had been added to over generations by bequests and gifts from the highly religious, rich classes of Mexican society. Two effects of this accumulation of wealth were: many joined the clergy without any vocation whatsoever, but purely to enjoy an easily acquired material well being; and many then paid more attention to the administration of their wealth than to ministering to their people. 55

Although the process of obtaining the vote of the people and the establishment of a more reliable government was not yet complete, it was obvious that Napoleon was

\footnotetext{
${ }^{52}$ Forey to Napoleon, probably 20 August 1863 according to Émile Ollivier, L'Empire libéral, Vol 6, p. 448. A longer extract is quoted by Egon Corti, Maximilian and Charlotte, pp. 386-388, undated but appended to a letter from Napoleon to Maximilian, 25 September 1863.

53 Émile Ollivier, L'Empire libéral, Vol. 6, pp. 446-447.

${ }^{54}$ Napoleon to Maximilian, 25 September 1863. Quoted by Egon Corti, Maximilian and Charlotte, p. 385.

${ }^{55}$ Paul Gaulot, L'Expédition du Mexique, Vol. 2, pp. 19-23.
} 
already envisaging that the French involvement in Mexico would change when this had occurred. His instructions became directed more towards the development of the selfsufficiency of Mexico as soon as possible, and in this regard he instructed Bazaine to begin improving the strength and organisation of the Mexican army. He also advised that in Paris the government was discussing the financial measures necessary to develop the resources of the country and suggested that once the new government demonstrated some stability it would be easy to organise a loan. In the meantime he reported to Bazaine that he had read an engineer's reports on the mines of Sonora and that a company was being formed which would develop them at their own expense. They promised to give a portion of the produce to the French government, and he suggested the Mexican government could impose a tax on this, thus providing a ready source of income. To this end Bazaine was asked to obtain for France, from the provisional government, mining concessions for all the mines exploited in Sonora. As compensation for the Mexican government a reduction in the amount of reimbursement requested by France for the costs of the war would be negotiated later. ${ }^{56}$

In the meantime the prolonged campaign was gaining little popularity in France, and was to be debated in the Corps Législatif in January 1864. According to Fleury the basis of this unpopularity was that many in the Emperor's government doubted the likely success of the government that had been created in Mexico because it was far too reactionary and out of sympathy with French politics and with the more liberal sentiments of the Mexican people. ${ }^{57}$ What had begun as a seemingly powerful moral demonstration against a reprehensible government had turned into a war, which to the public and the Opposition had confusing aims and no foreseeable outcome. Mazade commented that the misdirection given to the campaign by Almonte, and the inaccurate information he had provided had done nothing to increase its popularity or to help the French cause, and what had been envisaged as a short campaign had already lasted two years. ${ }^{58}$

\footnotetext{
56 Napoleon to Bazaine, 16 December 1863. Ibid., Vol. 1, pp. 224-225.

57 Fleury to Bazaine, 12 December 1863. Ibid., Vol. 1, pp. 232-233.

${ }^{58}$ Charles de Mazade, “L'Expédition du Mexique et la Politique Francaise”, pp. 675- 706.
} 
Despite the problems with the Regency Napoleon believed that a stable government would soon be established in Mexico. However, he was to continue to be presented with conflicting reports on the state of the country and the amount of acceptance a monarchy would have. When finally he was given the results of the consultation of the people, dubious though they proved to be, he prepared for the eventual withdrawal of the French army by encouraging the development of Mexico's ability to support itself. Once again he was to be confronted with unexpected difficulties, not the least of which was Maximilian's indecision about giving up his Austrian inheritance to go to Mexico.

Napoleon was also concerned with a number of urgent problems in Europe in 1863 and 1864 which have been said to have been the reason for his apparent loss of interest in Mexico and for his anxiety for Maximilian to go there. Although these problems consumed much of Napoleon's attention they did not cause him to lose interest in Mexico, as he had already intended that France would not remain involved there after the new government was established. It will be seen, however, that these events in Europe provide the opportunity to place the Mexican campaign into the perspective of Napoleon's overall foreign policy, and show that his intentions in Mexico were consistent with that policy and with his vision for Europe and the world. 


\section{Chapter 7}

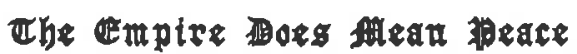

In 1864 Michel Chevalier commented, "the consolidation of political and social order" in Mexico was "subjected to causes which are independent of the will of France, and beyond her power to control .... The most profound of these causes are inherent to the present situation of the Catholic religion and to the attitude assumed by the hierarchy of the Roman Church in regard to the bases of modern civilization."' Bazaine found soon after his appointment as Commander-in-Chief that the clergy were indeed to be one of his greatest problems. He was armed with instructions to confirm the nationalisation of Church property, but the actions of the clergy led the people to think France intended to re-institute the retrograde policies of the Clerical party. In October he was reminded by a French resident of the damaging role played by the clergy in Mexico since the country had gained its independence from Spain, and of the power they were so reluctant to relinquish. The clergy, J.E. Schlœsing wrote, were responsible for the establishment and overturning of all the governments that had existed over the years. Their possession of one third of the country's wealth gave them enormous power and meant they could afford to buy the army for their own purposes, and exercise a more thought-destroying despotism than the previous colonial masters of Mexico. ${ }^{2}$ It was the corruption and despotism of the clergy that caused Mexicans to look towards France and aspire to a definitive revolution of their own, like that of 1789. Schlœsing said:

La nation s'était soustraite à la domination espagnole par sa guerre d'indépendance; elle a voulu se soustraire à la domination cléricale par un 89.

This had happened in 1856 and eventually the liberals had triumphed three years later, but now there was a fear that the clergy would regain its power. He continued:

\footnotetext{
${ }^{1}$ Michel Chevalier, Mexico, Ancient and Modern, Vol. 2, p. 264.

${ }^{2}$ Schlœesing to Bazaine, 14 October 1863. Quoted by Paul Gaulot, L'Expédition du Mexique, Vol. 1, p. 416.
} 
La tâche était ardue; il fallait, pour la mener à bien, une révolution véritablement populaire; aussi le pays s'est-il soulevé sur toure sa surface, les citoyens ont pris les armes, et le triomphe avait été assez décisif, assez complet, pour prévenir un 93; mais 93 suivrait infailliblement toute restauration. quelle qu'elle fût, de la domination cléricale. ${ }^{3}$

It was not to be long before Bazaine was to be confronted with an attempt by the Archbishop Labastida to regain that power the clergy had before the decrees issued by Juarez in 1861.

On his arrival in Mexico a few days after Bazaine received this letter, Labastida informed him that he was going to restore the power of the clergy and that the Emperor approved this proposal. At a meeting of the Regency on 24 October he told Bazaine that the French had only been accepted in the capital because of the influence of the clergy, and if Bazaine refused to work with him he could no longer count on the support of the clergy. But despite Labastida's opposition, and in accordance with his instructions, Bazaine managed to get the Regency to insert in the official journal a notice that all legitimate sales of national property would be confirmed. ${ }^{4}$ Although Almonte had supported this move by Bazaine he wrote to Napoleon that he thought Bazaine should take a more conciliatory approach with the clergy because they could still make use of the influence that they exercised in the country. ${ }^{5}$

But it was the apparent association of the French with the clergy that created many difficulties for Bazaine and his army, and the work of Saligny and Almonte in supporting the nomination of Labastida was mostly responsible. General du Barail wrote that when they were trying to clear some bandits out of the north of Mexico they encountered two French miners who gave them an account of how the Liberals felt about the French. They said:

Ne croyez pas ... un seul instant, que les libéraux soient hostiles aux Français et qu'ils dient envie de se battre avec eux. Ils n'ont qu'un plan: vous fatiguer par des marches continuelles et inutiles, et vous forcer à rentrer

\footnotetext{
${ }^{3}$ Ibid., pp. 416-417. Schlœsing was referring to the Reign of Terror that persisted throughout 1793 into 1794 in which any emergencies were dealt with by fanaticism, both internally and externaily, and human rights werevirtually suspended.

${ }^{4}$ Bazaine to Napoleon, 24 October 1863. Quoted by Émile Ollivier, L'Empire libéral, Vol. 6, pp. 454-455.

5 Almonte to Napoleon, 27 October 1863. AN: 400AP 61, Archives Napoléon.
} 
à Mexico. Leurs chefs considèrent la France comme la source du progrès et le flambeau de la civilisation; mais jamais ils n'accepteront le gouvernement réactionnaire et clérical que vous voulez leur imposer. ${ }^{6}$

They commented that Maximilian was already hated by the Liberals because they imagined that the priests would play a large role in his government. The French cause was seriously damaged then by the refusal of the Supreme Court to hear any of the cases referred to it for confirmation of the right to retain possession of legitimately bought church property. Public outcry demanded that the judges be dismissed for "upholding the pretensions of the archbishop and his clergy, which were as unjust as they were impolitic". ${ }^{7}$ The provisional government reminded the judges that they had to uphold the decrees of the previous Liberal government, but Labastida encouraged the judges to oppose this directive and then went even further. On 30 December he and his bishops served a document on the Regency which threatened excommunication of anyone who supported the nationalisation of church property. The judges then declared they would not execute the decrees and as a result were dismissed by the government. Labastida would not submit to the pressure of the two other Regents, Almonte and Salas, to leave this question to be resolved by the future Emperor, so they in turn rejected his proposal that the decrees of 1861 be overturned. In anger Labastida refused to attend any further meetings of the Regency.

Regardless of the steps taken by the Regency and Baraine, the issue of the influence that the clergy might exercise in the forthcoming government was to remain a concern. Michel Chevalier commented that the seriousness of this "embarrassment" could not be underrated. He said:

We have here to deal not merely with the clergy lands, nor with the opening of a chapel at Mexico, in which the Protestants may worship God in the form agreeable to their conscience: the question is a far wider one. In reality, the point to be settled is whether the new Government of Mexico shall adopt the mass of those liberal and progressive ideas to which all civilized States have successively rallied, or whether it shall run in the fated

${ }^{6}$ Général du Barail, Mes Souvenirs, Vol. 2, p. 496.

${ }^{7}$ Report from The Times correspondent in Mexico, 9 January 1864, published in The Times, 17 February 1864. 
track of those antiquated maxims, according to which all Liberty, religious, political, or economic is a curse. ${ }^{8}$

The only chance he saw for Maximilian to institute a progressive government was for him to appeal to the Holy See to order the Mexican clergy to co-operate with him in this endeavour. Maximilian, however, was to leave Europe without negotiating such support from Rome. Corti remarked that when Labastida had demanded of Maximilian, during discussions in Europe, a commitment to the restitution of Church property, "they had parted without any definitive pronouncement upon this highly important subject, for the Archduke was afraid it might be prejudicial to his candidature."9 The result was a problem that Maximilian never successfully resolved.

From November 1863 Napoleon was to be confronted by varying opinions on the state of the pacification of Mexico and whether or not France should continue its involvement there. Bazaine's optimistic accounts of the pacification of the country were supported by those of Almonte who claimed widespread support for the monarchy, and by the The Times correspondent in Mexico who wrote in similar vein. Other opinions almost diametrically opposed to their views abounded also, and received a voice through the French Opposition early in 1864. Although Napoleon was criticised, not least by Opposition politicians, for continuing with a hopeless situation, it can be seen that the information from his main sources was strong enough to negate, for him, the other opinions that reached Paris.

Unaware of the pending difficulties with the clergy in Mexico, he gave his address, Exposé de la situation de l'Empire, to the Corps législatif and the Senate. In discussing foreign affairs, a relatively brief mention was made of the Mexican campaign, but one of the issues referred to was that the decision of the notables had to be shown to be accepted by the majority of the people before Maximilian could be expected to go to Mexico. Napoleon advised his parliamentary bodies that the expedition had been undertaken to

\footnotetext{
${ }^{8}$ Michel Chevalier, Mexico Ancient and Modern, pp. xi-xii.

${ }^{9}$ Egon Corti, Maximilian and Charlotte, pp. 272-273.
} 
protect France's interests but it was hoped that the salvation of Mexico would be a possible consequence of the campaign. Although they were hoping in the near future to obtain guarantees from the new government there were still many questions to be settled, and "the resolution of the military situation could only prepare the way for later negotiations." 10

By December there was much impatience being expressed in Paris regarding the departure of Maximilian for Mexico, according to Prince Richard de Metternich. This was quite possibly instigated by reports from Almonte who wrote that support for the intervention and for the empire continued to arrive from all points of the country. In a letter to Napoleon he said that the Mexican army was already provisionally organised; all branches of the government administration were functioning well in the departments that had agreed to accept the Empire; and soon two thirds of the country would have voted in favour of the monarchy. Yet his confidence was somewhat belied by an ensuing comment that if Maximilian did not arrive soon it might be necessary to send a further two brigades to reassure the "timid people" who might begin to doubt Maximilian was coming, and that France would persevere in its enterprise. He added that the arrival of Maximilian would be equal to that of an army. ${ }^{11}$ It is by no means certain that his letter reassured Napoleon of the situation in Mexico.

Although pressing matters in Europe were said to have made Napoleon impatient to see Maximilian take over responsibility for Mexico, shortly after Almonte's letter would have reached Napoleon he had a conversation with Metternich in which he said that were he in Maximilian's place he would defer his departure until the situation was a little more advanced. Metternich remarked to Rechberg:

Cette assertion me parait importante, au milieu des bruits qui commencent à courir sur les impatiences et la mauvaise humeur de l'Empereur au sujet de l'Archiduc. ...

10 Exposé de la Situation de l'Empire présenté au Sénat et au Corps Législatif, November 1863 (Paris, 1863), Vol. 2, p. 117.

${ }^{11}$ Almonte to Napoleon, 27 October 1863. AN: 400AP 61, Archives Napoléon. 
L'Archiduc devrait peut-être s'assurer personnellement des intentions réelles de l'Empereur. ${ }^{12}$

He added, however, that the campaign was becoming more unpopular and yet he was confronted with many contradictions in that respect. In the Senate the address relative to affairs in Mexico was passed after the government assured the Senate that France had not declared war against Mexico just for the Archduke. Metternich reported that shortly after this session, however, someone had asked a government representative if Maximilian would be leaving soon and if France was going to provide him with any guarantees. The reply was apparently that he was to leave in two weeks and that he would not be given any guarantees. Metternich was naturally concerned and yet there is no evidence to support the claim that Maximilian might depart so soon. The issue of guarantees, however, did become important in the weeks before Maximilian finally departed in April 1864 and he spent some time in Paris with Napoleon in March to finalise them.

Contradictions in opinion as to the state of pacification of the country continued to make it difficult to know the real situation. The Times was read widely in Paris and Napoleon was encouraged at the support given by the Mexican correspondent of that newspaper to the claims of Bazaine. This correspondent wrote of the "cordial reception" accorded everywhere to the French and the ease with which they had occupied all of the largest cities, which proved that the claims in Europe that Mexico was essentially republican and supported Juarez were wrong. The rumours that had abounded that the Mexicans would "shed the last drop of their blood in defence of their much loved President and Constitution" were, he said, propagated by those who wished to keep the country in a state of anarchy to support their own contraband trade. He then proceeded to state that it was known that Santiago Vidauri, ruler of two of the Mexican States, was about to declare in favour of the intervention and by the end of December "the election of the Archduke will have been ratified by all the principal States and at least seven eighths of the population of the country. ${ }^{13}$

\footnotetext{
12 Metternich to Rechberg, 14 December 1863. H. Salomon, "Le Prince Richard de Mettemich", pp. 532-533. ${ }^{13}$ Report from Mexico, 16 December 1863, The Times, 20 January 1864.
} 
This report was referred to in the Moniteur two days later and used to support the government's policy in Mexico. The Moniteur claimed the report also helped to refute the extracts from a brochure on Mexico, printed in Opposition journals, which exaggerated "the difficulties of the expedition", denied "the advantageous results which may arise from it", and declared that "only a small portion of that country has declared in favour of France". The article in the Moniteur concluded by saying, "It is melancholy to think that in order to render justice to French foreign policy, there should be a necessity of seeking the truth in foreign journals, and not in those of France."14 The despatches of this correspondent in the following month gave even more glowing reports of the peaceful state of the country and the lack of resistance to the French occupation. He concluded in January that: "The military part of the expedition is now at an end, and an active police force is all that will be required for the future."15 In spite of these glowing reports from an independent source supporting Bazaine's accounts, it is interesting to observe an example of how Marshal Randon saw fit to edit Bazaine's reports at this time, although whether they were edited for Napoleon or for publication is difficult to know. The report is dated 5 January 1864 from Guadelajara and edited in Randon's handwriting:

La population semble est animée de bons sentiments parmi lesquels ta euriosité tient probablement le premier rang. 16

While varying opinions contimued to be expressed, and discussions with Maximilian about his departure proceeded, it was hard to deny that the situation in Mexico was appearing more favourable. The Paris correspondent of The Times reported that a confidential agent had arrived in Paris to treat with Napoleon in the name of Santiago Vidauri who had until recently supported Juarez. "He will assure the Emperor," he said, "that Vidauri had been for a long time sensible of the great benefit Mexico would derive from French intervention and the overthrow of the Juarez

\footnotetext{
${ }^{14}$ Summary of the article in the Moniteur printed in The Times, 22 January 1864. The brochure referred to is possibly one entitled, Solution de la question Mexicaine, by A. Malespine (Paris, 1864), a copy of which was found in AN: 223AP 16, Fonds Berryer.

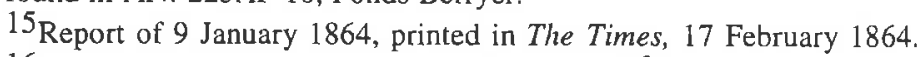

${ }^{16}$ Bazaine to Randon, 5 January 1864. AMG: $\mathrm{G}^{2} 1$
} 
Government." Juarez was said to have few, if any, followers now and Vidauri saw no further chance for him. The correspondent concluded that though Vidauri's "adhesion comes in somewhat late, it is not the less valued by the Emperor Napoleon, who will not be slow nor parsimonious in his estimate of it."17

Despite reports such as this, Napoleon was accused not only of concealing the true situation in Mexico, but also of having self-interested and imperialistic motives for being there, which had little foundation in fact. Public opinion was influenced both by varying reports on the state of things in Mexico, and by assertions, in the form of letters printed in newspapers, and articles in both French and foreign journals and newspapers. Napoleon's habit of not revealing all his ideas to the parliament or the public did not encourage support for the enterprise either, and the justification and criticism of this practice will be discussed shortly. Mazade remarked at the end of 1863 , however, that it was the unsupported assertions of individuals that provoked profound opposition to the politics of the government. As an example he quoted the public correspondence in Le Temps, of Hidalgo, one of the Mexicans intimately involved in promoting the intervention with European governments, with a Spanish friend. Hidalgo had said in one letter that if, as he expected, the Mexicans were in favour of a monarchy, there was no doubt that similar movements would follow in the other Spanish-American republics. As a result of such remarks France was suddenly transformed, Mazade said, into the promoter of such a movement and he concluded astutely:

C'est ainsi que le commentaire obscurcit notre œuvre réelle en donnant à notre politique une portée qui devient à notre insu une provocation à la méfiance contre nous, et qui dépasserait la limite de tous les intérêts de la France. 18

Nor is there evidence available to support the claim, taken up by some historians, that Napoleon intended to institute monarchies in other American countries.

\footnotetext{
${ }^{17}$ The Times, 2 April 1864.

${ }^{18}$ Charles de Mazade, "L'Expédition du Mexique et la Politique Française”, R.D.M., Vol. 48, 1 December 1863, p. 705 .
} 
Declarations on the Emperor's supposed motives were made also by foreign journalists such as Charles Mackay, an Englishman, who commented that the reason for the unpopularity of the venture within France was because it was "the work of Imperial ambition". However, he added that there were those who said "that Imperial ambition itself was but an instrument, and that the two proverbial agencies of immemorial mischief - the priest and the petticoat - are the true founders of the Empire of Mexico."19 It has been seen already that Napoleon was not influenced by the clergy and had no intention of restoring their power, but without access to information to the contrary many accepted claims such as those of Mackay. Similarly there has been much support for the idea that Napoleon was encouraged by the Empress Eugenie to intervene in Mexico, but the evidence in this respect is also far from conclusive.

Was Napoleon himself, however, responsible for the proliferation of motives that were ascribed to him by others? Count Fleury believed that if Napoleon's letter of instruction to General Forey of July 1862 had been published, the public would have been supportive of his "elevated motives", but he was prevented from doing so by concern he might compromise his relations with the United States. It was this concern, Fleury felt, that also prevented Napoleon from discussing frankly his "generous ideas" with his ministers and his friends and thereby convincing them of the possibility of the accomplishment of his great plans. ${ }^{20}$ And this secrecy led inevitably to conjecture and determined assertions about his motives, which he did not refute. The closest the world was to come to seeing his motives exposed was in the ideas expressed in his proposal of a European Congress in November 1863, but few were to recognise that his policy in relation to Mexico was consistent with the ideas expressed in that proposal.

Some understanding of his method of handling foreign affairs can perhaps be gained, though, from a letter to Prince Napoleon in response to some suggestions relating to the Polish situation earlier in 1863 . No notice of this comment appears to have

\footnotetext{
${ }^{19}$ Charles Mackay, "The French Conquest of Mexico", The Westminster and Foreign Quarterly Review. Vol. 80 , October 1863 , p. 316.

${ }^{20}$ Général Comte Fleury, Souvenirs, Vol 2, pp. 261-265.
} 
been taken by historians of the Mexican campaign, but it provides a significant insight into Napoleon's thinking, and a plausible explanation of his habit of secrecy. Napoleon said:

the very greatest prudence and the greatest skilfulness is required to reach a good result. ... I have to deal with powers who are very touchy, and the moment they have any reason to see ambitious views on my part they will reject any kind of alliance. On the other hand, if the Press determines to make me go faster than I think is wise, I shall be compelled to make declarations which will interfere with my policy. I want neither manifestations nor provocations, which always force one to make compromising declarations. ${ }^{21}$

As seen above, Mazade added support to Napoleon's comment on the impact of statements in the press on public opinion of government policy, and on the policy itself. When the suspicion with which Napoleon's intentions were regarded, particularly by England, is considered, as well as Fleury's comments about his concern to protect his relations with the United States, it is possible to see that his silence about his motives in Mexico were based on the same principles as those quoted above. It is not difficult to see some factors that forced Napoleon to move faster, or in a different direction, than he wanted in Mexico. One was in the precipitate action of the Mexican emigrants who approached Maximilian well before Napoleon was ready to proceed that far, and another was the action taken by Forey, and directed by Saligny and Almonte, of appointing a Regency and using the vote of the notables to declare Mexico was in favour of a monarchy.

Further insight into Napoleon's personality and style can be found in another letter to Prince Napoleon, this time in response to his urging that Napoleon should launch a coup in April 1849. It provides a clear statement of Napoleon's confidence in his own judgement and that he used his conscience and his own reasoning to decide what action should be taken.

I shall never submit to any attempt to influence me, and shall always make it my business to govern in the interests of the people, not of any party. I respect those whose ability and experience enable them to give me

\footnotetext{
21 Napoleon to Prince Napoleon, 22 January 1863. Quoted by Emest d'Hauterive, The Second Empire and its Downfall. The Correspondence of the Emperor Napoleon III and his cousin Prince Napoleon. Translated from the French by Herbert Wilson (London, 192-), pp.186-187.
} 
good advice ... . But I follow only the promptings of my mind and heart . . . . Nothing, nothing shall trouble the clear vision of my judgement or the strength of my resolution. I shall march straight forward with no moral scruples in the path of honour, with conscience my only guide. ${ }^{22}$

The fact that it was more than two years before Napoleon did launch a coup also shows that he was not in a hurry to realise his goals, but prepared to wait and make use of circumstances as they arose. This statement could also explain why Napoleon took so long to realise that he was being deceived about the situation in Mexico, and why he did not follow the advice of those around him.. It would seem he preferred to gather as much information as possible from a wide variety of sources before he made a decision, himself, on what was best to do. In the case of Mexico this practice prevented him sending a trusted aide, to assess the situation and give him accurate information, until late in 1866 . But in early 1862 there was no indication that it would be a difficult campaign.

While events in Mexico were marching slowly the issue of peace in Europe was being widely discussed, particularly in relation to the uprisings in Poland. It has been claimed by historians such as A. and $\mathrm{K}$. Hanna that this, as well as the European Congress proposed by Napoleon in November 1863, and the crisis in the Danish Duchies early in 1864, caused Napoleon to lose interest in Mexico and to wish to end France's involvement there as soon as possible. It has been seen already, however, that Napoleon's intention had long been to withdraw his troops as the new government became established in Mexico. In his instructions to Bazaine, Drouyn de Lhuys had emphasised the priority that was to be given to the reorganisation of the Mexican army because it was the desire of the government to limit, as quickly as circumstances allowed, the extent and duration of their occupation of Mexico. ${ }^{23}$

It can be shown that Napoleon's involvement in, and plans for Mexico were consistent with his motivation for proposing the convening of a congress to resolve the

\footnotetext{
${ }^{22}$ Napoleon to Prince Napoleon, 10 April 1849. Ibid., p. 53.

${ }^{23}$ Drouyn de Lhuys to Bazaine, 17 August 1863. A.D., Vol. 12, 1863, p. 290.
} 
problems between nations in Europe to maintain peace. His ideas in this respect, however, were the object of suspicion on the part of those he hoped to count as his greatest allies, England and Austria, whose scepticism of his intentions in Europe were reflected in their attitude to his involvement in Mexico. Napoleon was not the only one to recognise the strategic importance of a Polish nation in maintaining peace in Europe, or the balance of power, as Castlereagh had called it in 1814. It was natural then that he should want to see Russia restrained from destroying Poland in the face of the uprisings against Russian rule. When Russia and Prussia signed a Convention in February 1863 to co-operate in suppressing the Poles, Napoleon said the issue became an international one so he approached both England and Austria to advise Prussia not to be involved on Russia's part. He further proposed that the three Powers conclude an entente or protocol which would enhance their authority and guarantee solidarity in their approach to Russia to resolve the situation. But his proposal was accepted by neither England nor Austria, and Russia rejected the idea of any involvement in Poland by other Powers .

When Napoleon's attempts at a joint resolution of this important issue were rejected, he believed it was not appropriate for France to try to resolve the issue alone. The reasons he gave are entirely consistent with those behind his insistence that the expedition to Mexico had to be undertaken as a joint venture with England and Spain, and if possible with the concurrence of the United States. He said of the Polish situation:

Nous ne prétendons pas, toutefois, imposer nos solutions aux Puissances qui sont intéressées, autant ou même plus directement que nous, au règlement des difficultés pendantes. Dans une question essentiellement européennes, il n'est conforme ni à nos obligations ni à nos droits d'aller seuls au-devant d'une responsabilité qu'il appartient à tous de partager. ${ }^{24}$

The same principle was evident in Napoleon's instructions to Forey in July 1862 when he recognised that Mexico's position on the highway between the Atlantic and the Pacific was commercially significant to both Europe and the Americas, and therefore could not remain the province of a single nation.

${ }^{24}$ Exposé de la Situation de l'Empire, November 1863, Vol. 2, p.111. 
Napoleon was not considering abandoning Mexico to Maximilian because of the problems in Europe. It had always been his intention to see a new regime set up there that would be favourable to France and the rest of Europe, and when looked at in the light of his overall policy, that is revealed in his proposal for a European Congress, it can be seen that in fact Napoleon had no need to remain actively involved in Mexico once such a regime was established. In his address at the opening of the legislative session in November 1863 he said that "France's distant expeditions, such as those in CochinChina and Mexico ... were not the result of a premeditated plan: force of circumstances had brought them about". But he asked how France could develop its external commerce if it gave up the idea of any influence in the Americas. While they had encountered an unexpected resistance in Mexico, their efforts would not have been wasted and they would be compensated for their sacrifices "when the destiny of the country, which will owe its regeneration to France, was handed over to a Prince whose ideas and policies make him worthy of such a noble mission." 25

The idea of a community of nations gathering to discuss and try to resolve issues that affected them all was not a new idea for Napoleon. Apart from the communal action against Mexico, Napoleon had proposed on previous occasions the idea of a congress to try and resolve the Italian and Roman problems, in 1848 and 1860, but on each occasion the idea was rejected. The suggestion of a congress in 1863 was precipitated by the failure of his attempts to resolve the Polish situation. In presenting his idea to the legislative assembly in November 1863 , he asked rhetorically if the only avenues now open to them were either to go to war or to remain silent. Not wanting to accept eicher of these alternatives, he thought the Polish cause should be submitted to a European tribunal along with all other questions disturbing Europe. In expounding his ideas he revealed how far ahead of his time he was for many of his contemporary leaders. In his letter to the sovereigns of Europe he wrote:

Toutes les fois que de profondes secousses ont ébranlé les bases et déplacé les limites des Etats, il est survenu des transactions solennelles, pour

25 Address at the opening of the Legislative Session, 5 November 1863. A.D., Vol. 12, 1863, pp. 163-164. 
coordonner les éléments nouveaux et consacrer en les revisant, les transformations accomplies. Tel a été l'objet du traité de Westphalie, au dixseptième siècle, et des négociations de Vienne en 1815. C'est sur ce dernier fondement que repose aujourd'hui l'édifice politique de l'Europe; et cependant... . il s'écroule de toutes parts.

Si l'on considère attentivement la situation des divers pays, il est impossible de ne pas reconnaître que, presque sur tous les points, les Traités de Vienne sont détruits, modifiés, méconnus ou menacés. De là, des devoirs sans règle, des droits sans titre et des prétensions sans frein. Péril d'autant plus redoutable que les perfectionnements amenés par la civilisation, qui a lié les peuples entre eux par la solidarité des intérêts matériels, rendraient la guerre plus destructives encore.

C'est là un sujet de graves méditations. N'attendons pas pour prendre un parti que des événements soudains, irréstibles, troublent notre jugement et nous entraînent, malgré nous, dans des directions contraires. Je viens donc proposer à Votre Majesté de régler le présent et s'assurer l'avenir dans un Congrès. ${ }^{26}$

Napoleon's proposal was met either without any, or with only minor reservations on the part of Portugal, Hanover, Italy, Prussia, Bavaria and the German Confederation. The only proviso imposed by Tsar Alexander of Russia was that Napoleon outline the questions he thought should be discussed at the Congress. The Emperor Franz-Josef of Austria expanded on this idea, saying that specifying the questions in advance and having agreement on the direction intended would help avoid any unforeseen obstacles. His decision about involvement would be made after his Ambassador, Metternich, had discussions with Napoleon. His idea was expanded to Metternich by Rechberg who said:

Pour apporter à un Congrès notre loyal concours, nous devons connaître quel sera le programme exact de ses délibérations, et être assurés que ce programme remplit toutes les conditions requises pour préparer l'élaboration d'une œuvre de paix et de conciliation. ${ }^{27}$

Austria's reply was very similar to England's, and they both focused on the point that Napoleon had made about the Treaties of Vienna being menaced or modified, and showed that they were both afraid that Napoleon intended to propose some rearrangement of Europe himself as a consequence. I believe this could not be further from the truth, but Cowley's immediate reaction, and the later replies of both England

${ }^{26}$ Napoleon to European Sovereigns, 4 November 1864. A.D., Vol. 12, 1863, pp. 188-189.

${ }^{27}$ Rechberg to Mettemich, 17 November 1863. A.D., Vol 13, 1864, pp. 59-60. 
and Austria show that this fear was real on their parts. Cowley's initial comment to Russell was that he considered the proposal "mischievous" and "dangerous ... for the Continental Powers. The position of Austria is terrible. Acquiescence implies the loss of Gallicia and perhaps Venetia. Refusal may induce the Emperor, aided by the Italians, to try if he cannot reach (?) Poland thru [sic] Austria."28 There is no evidence that this observation is anything other than supposition on Cowley's part, however, and Russell responded that he thought a congress was "practicable but that they must soon arrive at the question of war or no war. Is it easier to solve that question in a Congress, or by common diplomatic means? That question requires much and long deliberation." 29 It is interesting to speculate, however, on the influence of Cowley's remark on the forthcoming responses of England and Austria.

Rechberg asked Metternich to determine in what respects Napoleon thought the Treaties of Vienna were no longer effective because Franz-Josef believed they still formed "the basis of public law in Europe". Russell wrote to Cowley that his government believed "the main provisions of the Treaty of 1815 are still in full force" and that the balance of power in Europe still rested on its foundations. He added:

If instead of saying that the Treaty of Vienna has ceased to exist or that it is destroyed, we inquire whether certain portions of it have been modified, disregarded or menaced, other questions occur. Some of the modifications which have taken place have received the sanction of all the Great Powers, and now form part of the public law of Europe.

Is it proposed to give those changes a more general and solemn sanction? Is such a work necessary? Will it contribute to the peace of Europe? ${ }^{30}$

It is no coincidence that these replies have similarities because Bloomfield, British Ambassador to Vienna, reported on 12 November that Austria was concerned that it be in agreement with England about the Congress and wanted to make sure that their written replies agreed but were not word for word..$^{31}$

\footnotetext{
${ }^{28}$ Cowley to Russell, 5 November 1863. PRO: PRO30/22/59, Russell Papers.

${ }^{29}$ Russell to Cowley, despatch in cypher, 7 November 1863. PRO: FO27/1482.

30 Russell to Cowley, 12 November 1863. PRO: FO27/1482.

${ }^{31}$ Bloomfield to Russell, 12 November 1863. PRO: PRO30/22/42, Russell Papers.
} 
As far as those parts of the Treaty of Vienna that were currently being "menaced" were concerned, Russell wanted to know what Napoleon's proposals were, and, if they were agreed by a majority of the Powers, would they be enforced by arms? England's main concern was that specific issues should be addressed by the Congress, for they would feel more apprehension than confidence from the meeting of a Congress of Sovereigns and Ministers without fixed objects ranging over the map of Europe and exciting hopes and aspirations which they might find themselves unable either to ratify or to quiet.

Drouyn de Lhuys replied that Napoleon had deliberately addressed all the Courts simultaneously without any preconceived ideas about ententes with any of them, in order to show his sincere impartiality and be able to approach the discussions free from any obligations. As the newest Sovereign, Drouyn de Lhuys said, Napoleon did not believe he had the right to assume the role of arbitrator or determine in advance the programme for the Congress. He proceeded, however, to outline some of the areas for concern in Europe such as: the Polish uprising; the pending dispute over the Danish Duchies; the unresolved conflict between Italy and Austria; the continued occupation of Rome; and most importantly, the excessive armaments maintained by all countries because of the mistrust harboured between them. Suggesting that these were probably the main issues everyone would want to discuss, he added:

Lord Russell n'attend pas, assurément, que nous indiquons ici le mode de solution applicable à chacun de ces problèmes, ni le genre de sanction que pourraient comporter les décisions du Congrès. C'est aux Puissances qui y seraient représentées qu'appartiendrait le droit de prononcer sur ces divers points. Nous ajouterons seulement que ce serait, à nos yeux, une illusion que de poursuivre ces solutions à travers le dédale de correspondances diplomatiques et de négociations séparées, et que, loin d'aboutir à la guerre, la voie proposée est la seule qui puisse conduire à une pacification durable. 32

At no time had Napoleon made any suggestion that any nation should be asked to cede territory, but England was convinced that this might be Napoleon's fundamental aim, and pointed out all the difficulties that would prevent a congress from resolving such demands. Russell also doubted any benefit would be gained from convening a 32 Drouyn de Lhuys to Marquis de Cadore, Chargé d'Affaires in London, 23 November 1863. A.D., Vol. 13,
1864 , p. 48. 
large number of representatives, which included those from nations totally unaffected by many of the current issues, expressing "opinions and wishes" that could not be enforced. Not being able to see any "beneficial consequences" likely to arise from the proposed congress the English Government declared itself unable to accept the invitation of Napoleon, and thereby dealt France a severe blow.

Despite the rejection by England, Napoleon received great support for his idea from other countries, notably Denmark, and from within his own country. The Senate voted unanimously in favour of the proposal made by Napoleon, and speaking on behalf of the entire country the President of the Senate said:

Elle a donc applaudi avec transport à votre proposition d'un Congrès: prévoyante idée qui offre à notre patrie des satisfactions exemptes d'ambitions; à l'Europe, des garanties de paix et le désarmement; à la civilisation une libre et vaste carrière pour ses développements. Puissent les souverains, guidés par leur haute raison et par les lumières du siècle, s'unir à Notre Majesté pour une tâche qui, allant au-devant les luttes au lieu d'en attendre l'explosion, réglera les prétentions et mettra le droit des gouvernements en harmonie avec les vœux légitimes des peuples. ${ }^{33}$

Napoleon was delighted with the address of the Senate and the support his idea received, and despite his disappointment at England's rejection of it, he later said that "I could not at heart find fault with her course, for I knew that she always prefers to settle her own affairs alone, in the best way for her own interests." 34 Political writer, Thornton Hunt, who was connected with one of the major English newspapers, had discussions with Napoleon when he was in exile in England after the fall of the Empire, and was completely impressed with the benefits that could have resulted if the Congress had gone ahead. He had found several English politicians who at the time had not understood the implications of Napoleon's proposal but later saw them in a very favourable light.

Napoleon had shared some of his ideas on how he saw an International Council working, and Hunt had wanted him to develop them further. Napoleon died on 9 January 1873 before he could approach him again, but what Hunt reported of his

${ }^{33}$ Address by the Senate, presented to Napoleon 21 December 1863. A.D., Vol. 13, 1864, pp. 81-82.

${ }^{34}$ Comte Fleury, (ed.) Memoirs of the Empress Eugenie, 2 Vols. (New York, 1920), Vol. 2, pp. 147-148. 
conversations with him to Count de la Chapelle, a friend of Napoleon in exile, is inspiring. Napoleon had suggested an International Council might meet every few years and the benefits would be that its deliberations could clear up differences, because "it would impose on the contesting parties the weight of international opinion, and thus settle the dispute for years." If a quarrel arose again before the Council was due to meet, other nations would advise those involved to have patience and wait for the question to be brought before it. This latter point may have been idealistic, but the final comments made by Napoleon illustrate how broad was his view of the world, and how much his interests were outward looking:

... the minutes of this International council would serve as bases for a code of international laws. This would be an important innovation, for, properly speaking, international laws do not exist, and we have at present no other guide than the works of learned jurisconsults, the statutes of various nations, and theory.

... to these anticipated results of the International Council there will also have to be added this important fact: it would not be long before the Congress would found an international parliament, which would serve, not only for sanctioning fresh laws, but also for amending those old laws which have been rendered obsolete by the ever-increasing progress of our times. ${ }^{35}$

Napoleon's optimism may have been tested by the decades it took for some of his ideas to come to fruition.

Chapelle said that the Emperor had intended to develop his thoughts further and had commissioned him to prepare them for him. He described Napoleon's idea as "that admirable system which will be no doubt adopted when governments are wiser, and when they give to the interests of the peoples under them a higher place than to their own personalities." 36 Hunt commented that when an International Council did eventuate he hoped mankind would remember that Napoleon "was the founder of this court of legislation and of judicial appeal for nations". ${ }^{37}$ And these ideas do not seem so Utopian when the establishment of the League, and later United Nations are considered, as well

\footnotetext{
${ }^{35}$ Count de la Chapelle, Posthumous Works and Unpublished Autographs of Napoleon III in Exile (London, 1873), pp. 253-254. Count de la Chapelle had lived abroad for eighteen years before Napoleon was exiled to London, and became a friend and confidant of Napoleon until his death in 1873.

36 Ibid.

37 Ibid., pp. 254-256.
} 
as the relatively recent European Parliament. The name of Napoleon III, however, is remembered by very few when the origin of these organisations is discussed.

Can a parallel really be drawn between this grand proposal of Napoleon's and his involvement in Mexico? My research shows that it can. Napoleon's concern for better relations among all nations, in his proposal of a congress to resolve the problems that were facing Europe, and to ensure a future peace, is difficult to dispute. Why then should his intentions have been any different in Mexico, when they were based on the same principle - a community of nations working together to resolve a situation for the benefit of all nations, with the aim of ensuring prosperity and stability? This comparison has not been considered previously, but there are some obvious parallels to be drawn which help explain Napoleon's involvement in Mexico. William Echard is one of very few historians to have studied seriously Napoleon's proposals for congresses and concluded that he was a true Europeanist. ${ }^{38}$ This conclusion can be expanded to show that Napoleon's wider foreign policy was consistent with his European policy exposed so fully in November 1863. This is possible because Napoleon's correspondence shows clearly that he had no intention of claiming territory for France, or exclusive control of commerce in the Americas, and that his troops were to be withdrawn immediately a stable government was established. The most important parallel with his congress proposal is his stated belief that he was acting to ensure benefits for all nations, including Mexico.

If all of the correspondence between Napoleon and his commanders had been considered, and his intentions accepted as they were openly stated, many of the controversies surrounding the intervention may have been avoided. Many historians, however, have been as suspicious of Napoleon's intentions as England was, and remain convinced that he was determined to ensure France regained its supremacy in Europe and as a world power. It was England that doubted Napoleon's motives and thwarted his hopes for a united Europe and a combined approach to one of the world's problems,

38 William E. Echard, Napoleon III and the Concert of Europe. 
Mexico. Napoleon's cause was not helped either by English journalists such as Charles

Mackay who wrote in October 1863:

No impartial man who studies the history of the expedition can entertain the slightest doubt that the Emperor Napoleon designed from the very beginning the dispute between the Allies, and the withdrawal of England and Spain. . . . He got rid of [England's] cooperation just at the point when it ceased to be a convenience and would have become an embarrassment. The period had come when France must either retreat or openly assume the policy of invasion and conquest. The dispute between the Allies, deliberately provoked and rendered necessary by France, afforded a decent opportunity for the French intervention to emerge into the light, and assume its true character. ${ }^{39}$

Just why Napoleon should resort to such an elaborate exercise if he all along intended to act alone is not explained. This assessment can have been based only on limited access to official documents, and quite probably mostly on conjecture, but it would no doubt have influenced some sections of the British public.

In France the Corps législatif showed that it was not in favour of a prolonged involvement in Mexico, although its members intimated that they were prepared to support the government if protection of France's honour necessitated an extension of time. These sentiments were made evident in the report of the Commissions of the Budget on the supplementary credits of 1863 in which they said:

Dans les prévisions actuelles, le Gouvernement espère que la fin de 1864 marquera le terme de l'expédition. Nous sommes unanimes à conseiller de mettre un terme à l'expédition du Mexique, non pas à tout prix, Dieu nous en garde! mais aussi promptement que l'honneur et l'intérêt de la France le permettront. L'expression de ce vœu répond au sentiment général du pays. ${ }^{40}$

It will be recalled that Napoleon's instructions to Bazaine in August had stressed that the government was anxious to limit the duration of their involvement, and that Bazaine had to undertake the immediate development of the Mexican army with that view in mind, so this report was congruent with Napoleon's own thoughts at this time. But in January 1864, an amendment to the Emperor's address to the Corps législatif, "that France

\footnotetext{
${ }^{39}$ Charles Mackay, "The French Conquest of Mexico", The Westminster and Foreign Quarterly Review, Vol. 80, October 1863, pp. 335-336.

40 Larrabure, "Rapport sur les crédits supplémentaires de 1863". Quoted by Émile Ollivier, L'Empire libéral, Vol. 6, p. 460.
} 
should withdraw from Mexico", was defeated soundly by 201 votes to 47 . The results of the vote, however, do not indicate the intensity of the discussion. The debate was opened by the Vice President of the Council of State, M. Chaix d'Est-Ange, who admitted that France may only occupy one tenth of the country of Mexico but 5.5 million of the 7.7 million Mexicans had declared in favour of the intervention. He recognised that the Assembly was not favourable to distant expeditions which were said to cause uneasiness in the country, but asked if that was a good enough reason not to undertake them. France's industries had had setbacks recently which meant they had to be more active against foreign competition and increase their markets, which could only be achieved through such expeditions.

He also referred to the expedition against Mexico in 1838 by the July Monarchy which only resulted in the seizure of the port of St Jean d'Ulloa because they did not have enough landing troops. The Mexicans easily defeated them and expelled all the French from the country and closed their markets to France. The honour of France was severely damaged by this and other ill prepared expeditions to Montevideo and Morocco in 1844, so the Emperor was not prepared to leave Mexico this time until France's honour was avenged. This argument is supported by an article which Napoleon had written in an Opposition Journal, Le Progrès du Pas de Calais, in the early 1840s in which he criticised these ineffective undertakings of the government which so damaged the honour of France. When quoting this article in January 1864, the Paris correspondent of The Times commented that "the Prince who wrote it will not imitate the Government he denounced, or return from Mexico until he has established order and good government on a solid basis. By doing so he will be entitled to the gratitude of France." 41

The Opposition arguments were put forward by MM. Favre, Thiers and Berryer and were based on criticisms of how the campaign had been managed so far, and the

\footnotetext{
41 The Times, 30 January 1864. This debate was reported in great detail in The Times during the last week of January 1864.
} 
likelihood of a prolonged period in Mexico. Favre declared that the claims France had on the Mexican government were only a pretext for enthroning Maximilian, and that they only really controlled that part of the country their soldiers occupied, a view which had its support from correspondents in Mexico. He also questioned the influence of the Mexican emigrants on France's involvement and demanded to know whether France had fulfilled the conditions demanded by Maximilian. He stated that it was not true that all of the great cities of Mexico were in their favour and that therefore much more fighting and money would be required. Thiers declared that having reached Mexico City, France's honour was satisfied, and they should have treated with Juarez and retained the custom ports for revenue and saved France 14 or 15 million francs per month. He believed it would be impossible for Mexico to support a monarchy and France would have to continue to do so for many years. So far France had not pledged its honour to Maximilian, but the moment he left for Mexico under France's guarantee, they would be bound to him. Berryer added that the United States would not accept a monarchy in Mexico, and perhaps in time Spain and England would be jealous of France's influence there and problems among the three nations would arise.

It would seem Berryer's opinion regarding Mexico was consistent with the sentiments expressed in a brochure, written in 1864 by A. Malespine, entitled "Solution de la question mexicaine", which was found amongst his papers. Malespine suggested that in order to find out what the people wanted there should be an armistice of three months during which time a vote should be held, under the supervision of delegates for both the provisional government and Juarez, to decide if they wanted a monarchy or to maintain the Republic and the Constitution of 1857. If the French and Juarez each agreed to accept the decision of the people then whichever government was chosen would have the support of the people and the Clerical party would lose its influence. He concluded by asking, would it not be more sensible to treat with Juarez and avoid further bloodshed by putting the choice to the people, and by so doing avoid the prospect of conflict with 
the United States. ${ }^{42}$ This appears to be a very sound suggestion, but given the decision of the three allied governments not to negotiate with Juarez it was unlikely that it would gain support from the French government at this time.

Eugène Rouher, who was appointed Minister of State after the death of Billault, concluded the argument for the government and it would seem that his address had a strong influence on the vote that followed. Rouher was a lawyer and a Bonapartist and long-time friend of Napoleon, having been appointed Minister of Justice in the Second Republic. He had been an influential adviser to Napoleon since he first came to power, and the position he presently occupied as defender of government policy was one of considerable importance in the Corps législatif. He dismissed the idea of treating with Juarez because it had been agreed by the allied governments before their departure that his government had been discredited. Although there is perhaps merit in the argument that Juarez's regime, supported by the allies, would have made a strong and stable government, enough information to this effect was not given to Napoleon to reverse his decision not to treat with Juarez.

One of the government's strongest arguments for remaining in Mexico was for the protection of its maritime and commercial interests in that part of the world, particularly the West Indies. Although their commerce with Mexico only amounted to about 20 million francs at present, that with other states of South America had almost doubled in ten years, from 268 million in 1852 to 572 million francs in 1862 . The government could not say how long they would need to stay to protect their interests but it wished to leave as soon as possible. Rouher concluded his address with an emotional statement:

si quelqu'un prend la plume de l'historien, il dira: Celui-là fut un homme de génie qui, à travers les résistances, les obstacles et les défaillances, eut le courage d'ouvrir des sources de prospérités nouvelles à la nation dont il était le chef. (Applaudissements.) Celui-là fut l'apôtre d'une politique hardie, mais prévoyante et sage, qui reconnut que l'équilibre européen n'est plus comme aujourd'hui sur les Alpes, les Pyrénées, ou le Pont-Euxin, mais qu'il embrasse le monde entier, et que de si grands intérêts doivent être l'objet de la sollicitude de la France, si loin qu'il faille aller les protéger par

\footnotetext{
${ }^{42}$ A Malespine, Solution de la question mexicaine, (Brochure, Paris, 1864). AN: 223AP 16, Fonds Berryer.
} 
le drapeau français. Oui, cette page sera glorieuse! (Applaudissements prolongés. $)^{43}$

While recognising that Rouher was a staunch supporter of Napoleon, although extremely conservative in his views on liberal reforms, this is still a further illustration of how the Mexican campaign can be seen to be consistent with Napoleon's proposal for a congress, and with his overall policy. For the first time his world vision was described, and there is little reason to doubt the authenticity of Napoleon's policy as described by Rouher.

Ollivier commented that after this rousing reception the Assembly did not want to hear the response of Favre, even though it was always the custom to allow someone to respond after a minister spoke. Thiers called out, "You do not want to hear the truth!", but the motion was defeated by 201 votes to 47 . Despite this result, Ollivier claimed that in fact "at the bottom of their heart" three quarters of the Assembly disapproved the government's politics in relatio to Mexico. The correspondent for The Times remarked that some had obviously been persuaded by the eloquence of Rouher because there were many who voted against the amendment who had expressed rather different opinions previously. His own opinion was that regardless of the truth or otherwise of the Opposition's arguments, the fact was "that the French Army cannot be withdrawn before it shall have founded order in a country whose normal condition has long been the most frightful disorder." 44 It is interesting to speculate on why Ollivier believed that despite their vote such a large number really disagreed with the policy relating to Mexico. It is just as possible that they were persuaded to support it, not just because of Rouher's eloquence, but because they now had a better insight into Napoleon's policy and were therefore willing to support it. It may also have been the result of a word passed by Morny to one of the "Five", on the suggestion of Napoleon. According to Baron d'Ambès, Napoleon thought the Opposition was justified in criticising the government for its involvement in Mexico, but as he wanted to withdraw as soon as possible he said

\footnotetext{
${ }^{43}$ Quoted by Émile Ollivier, L'Empire libéral, Vol. 6, pp. 464-465.

${ }^{44}$ The Times, 30 January 1864.
} 
it would be helpful if Favre's amendment was withdrawn. Morny was called on to help and he said to Favre's colleague:

You know ... that we too want to get out of that wasp's nest? But we don't want, as you may fancy, to look as if we are yielding to the Opposition. If it makes things too warm for us, we shall have to stand our ground. Would it not be more patriotic in you to help us, instead of fighting us, under the circumstances?

D'Ambès commented:

The words were repeated. The amendment was withdrawn. Morny is a 'cute hand'. 45

If $\mathrm{d}$ 'Ambès was correct, and he says he was present at the discussion between Napoleon and Morny, obviously nothing was said to the four other members of the "Five".

Napoleon was not insensitive to the presence of opposition to involvement in Mexico. Therefore he continued in the direction that Rouher had outlined in his address, which was to reduce France's commitment as quickly as possible. He had done what he had set out to do and prepared the way for the establishment of a stable government, laid the groundwork for the development of the country and its resources, and ensured that European access to American markets would be maintained by preventing the southward encroachment of the United States. His negotiations with Maximilian during the ensuing weeks illustrate his commitment to fulfilling his aim of reducing France's involvement at an early date. They also illustrate that he had not lost interest in Mexico because of the rejection of his Congress.

When the dubious results of the plebiscite reached Europe, Maximilian gave his commitment to accept the throne of Mexico, subject to certain conditions that were negotiated with Napoleon. Once he had done this, Napoleon was anxious that he take up his position as quickly as possible so France's commitment could be reduced. But the Emperor has been criticised for pressuring Maximilian, and accused of wanting him to take responsibility for a situation which he knew was out of hand, and in which he no

\footnotetext{
${ }^{45}$ Baron d'Ambès, Intimate Memoirs, pp. 280-281.
} 
longer wanted to be involved. A. and K. Hanna said that Napoleon wanted to wipe his hands of Mexico in the wake of the rejection of his European Congress so he could refocus his attention in Europe. To do this, they said, he had to encourage Maximilian to go there as soon as possible. To the contrary, it will be seen that Napoleon's intentions relating to involvement in Mexico were always consistent with his policy and view of the world, and events in Europe did not dramatically change that view. But once Maximilian agreed to go, which he did in the knowledge of difficulties he would encounter, he had a duty to fulfil his commitment, and his brother, Emperor Franz-Josef, was of the same opinion as Napoleon in this respect. Corti, among others, showed that Maximilian was perhaps naively excited at the idea of being Emperor, particularly for the sake of his young wife, but nonetheless he made the decision to accept the throne and the fate that awaited him.

In his discussions with the Archduke, Napoleon had guaranteed material support for the new Empire in the form of French troops who would be gradually withdrawn as the Mexican army and the foreign forces were developed. After their withdrawal he would leave the Foreign Legion of six thousand men for six to eight years. He added that

the Archduke might rest assured that he had every interest in not leaving his work unfinished, and that the French troops would not be withdrawn so long as any danger to the stability of the Government remained; but Ferdinand Maximilian must realize that, in view of the opposition of public opinion in France and of the Corps Législatif, the Emperor could not promise in advance to leave the troops in Mexico for a definite period. ${ }^{46}$

Maximilian had responded that he was prepared to accept the throne of Mexico if Napoleon increased the Foreign Legion to eight thousand men and accepted his proposals for repayment of Mexico's debt to France. In March final negotiations were carried out in Paris and a loan floated for the new empire, after which Maximilian returned to Austria to prepare to leave for Mexico.

\footnotetext{
${ }^{46}$ Egon Corti, Maximilian and Charlotte, pp. 305-306.
} 
Until the moment was almost upon him, Maximilian said he was prepared to accept the crown of Mexico, as long as certain conditions were fulfilled, the most important being the vote of the people. During the debate in the Corps législatif in January it was claimed that 5.5 million of 7.7 million Mexicans had voted in favour of the Empire, but Émile Ollivier challenged the validity of those votes. He said reports received showed that in each town or village, if the army found notables prepared to accept municipal functions they would install them and make them sign an agreement with the vote of the notables in Mexico city. If no Mexican notables were found, the local administration was given to the French military, who then gathered any important persons they could find and told them if they did not vote for the empire they would be driven from Mexico. Another method was to write the total of the population of an area and count that as the number of adherents to the monarchy. ${ }^{47}$ Although Ollivier does not cite his source for this information, in view of General du Barail's comments seen above, it is quite possible that individuals in the army may have conducted the vote in such a manner, but it was not at the bidding of Napoleon.

Bazaine did, however, write to Napoleon admitting that the votes "were not the result of universal suffrage", adding:

Mais ce n'est pas moins l'expression de la grande majorité des États délivrés, car l'élément indien qui habite les campagnes suit toujours l'élément mexicain qui habite les centres principaux. La masse indienne n'a jamais été sincèrement consulté par aucun parti, et le prétexte en est simple: on les regarde comme des gens sans raison. Pour les amener genta de razon, il faudrait changer par un coup de baguette l'organisation sociale du pays. Comment établir des listes électorales quand ici l'état civil n'existe pas? Tout en étant convaincu que les actes d'adhésion représentent l'opinion des gens de raison du Mexique, et que l'Archiduc peut sans remords s'appuyer sur cette manifestation, je n'en ai pas moins fait préparer un plébiscite et n'ai point le moindre doute sur le vote. ${ }^{48}$

Napoleon was not happy that the vote reflected the wishes of only the majority of the States that had been liberated, and he instructed that a proper plebiscite was to be held. There have been many examples cited to show Napoleon was adamant the people had to

47Émile Ollivier, L'Empire libéral, Vol. 6, pp. 455-457.

${ }^{48}$ Bazaine to Napoleon, 24 March 1864. Ibid., pp.574-578. This date may be wrong, as Napoleon is supposed to have ordered a proper plebiscite after receiving this letter, and this was to be held at the end of March 1864. 
make this choice, and Pierre de la Gorce showed that the sovereignty of the people was the first article in Napoleon's political creed. He wrote:

Le peuple peut déléguer l'autorité, mais il garde un droit supérieur, celui de ressaisir et de reprendre ce qu'il a donné. Telle est la doctrine développé dès 1832 dans les Rêveries. Ce que Bonaparte proclame à vingt-quatre ans, il le redira en ses jours de prospérité; et cette reconnaissance du droit populaire sera comme l'hommage du souverain qui gouverne à un souverain plus auguste encore. 49

Again there is no reason to believe Napoleon would suggest for Mexico a system totally opposed to that he believed in for France. In view of a recent resurgence of opposition by Juarez's army, however, Bazaine decided that he would leave it to Maximilian when he arrived to decide if he wanted to accept the situation, or have it confirmed by a vote by universal suffrage. 50

When this questionable result reached Europe, Maximilian had accepted it and negotiated guarantees from France which were satisfactory to him. Apart from the problem with his own family, which arose after his departure from Paris, there was then no reason for him not to be prepared to undertake the commitment he had made. He is reported as saying, however, that he would have jumped for joy if someone had come to tell him that everything had fallen through, but that Charlotte was the one who would have been disappointed. Paul Gaulot who reported this added:

Ce prince, épris d'art, de littérature, de poésie, poète même à ses heures, avait été séduit un instant par l'éclat d'un trône, par ce rêve d'empire qui le mettait, dans sa pensée, l'égal de son frère aîné et de Napoléon III, sinon comme puissance, du moins comme prestige extérieure, mais son âme n'avait point la sécheresse des politiques ni l'énergie des ambitieux. Son rêve l'éblouissait; la réalité l'effrayait. ${ }^{51}$

When Maximilian returned to Vienna from Paris both Napoleon and the Emperor Franz-Josef were forced to remind him of his duty and of upholding both his own and their honour when he suddenly began to hesitate over his decision to go to Mexico. They in turn were to be accused of putting undue pressure on the Archduke. But having

\footnotetext{
${ }^{49}$ Pierre de la Gorce, Napoléon III el sa Politique (Paris, 1933), pp.27-28.

50 Montholon, the new French Minister in Mexico, to Drouyn de Lhuys, 28 April 1864. Quoted by Émile Ollivier, L'Empire libéral, Vol. 6, p. 578.

${ }^{51}$ Paul Gaulot, L'Expédition du Mexique, Vol. 1, p. 297.
} 
assured his own country that France would not be committed in Mexico indefinitely, Napoleon was suddenly confronted with the possibility that Maximilian would not go and new negotiations might have to be undertaken. Maximilian had been asked by Franz-Josef to sign an agreement not to make any claim on the Austrian throne for himself or the sons he might have. Maximilian was mortified and declared that he would no longer go to Mexico. On hearing this Napoleon wrote:

By the treaty concluded between us, and mutually binding upon us, by the assurances given to Mexico, by the pledges exchanged with the subscribers of the loan, Your Imperial Highness has entered into engagements which you are no longer free to break. What, indeed would you think of me if, once Your Imperial Highness had arrived in Mexico, I were to say that I can no longer fulfil the conditions to which I have set my signature?

.... It is absolutely necessary in your own interests and those of your family that matters should be settled, for the honour of the house of Habsburg is at stake. 52

Napoleon sent this letter with his close aide-de-camp, General Frossard, to impress on Maximilian the gravity of the situation.

This dilemma of Maximilian's is interesting because Frossard learned from FranzJosef on his arrival in Vienna, that Maximilian had known before he went to Paris that he would have to renounce any claim to the Austrian throne. However, Franz-Josef blamed himself for Maximilian's hesitations now because he said he should have discussed having the renunciation in writing before the Archduke had gone to Paris. It was having to put the undertaking in writing that concerned Maximilian, for the sake of the sons he might have. Frossard reported this conversation to Napoleon, saying that he had remarked to Franz-Josef that he could see that this issue was a pressing question of honour for the Archduke, but the Austrian Emperor had responded:

Oui, une question d'honneur pour nous tous; il faut que cela s'accomplisse; j'y fais tous mes efforts; mais aussi il faut que mon frère se soumette aux conséquences de la nouvelle situation, en ce qui regarde notre propre pays. ${ }^{53}$

\footnotetext{
52 Napoleon to Maximilian, 28 March 1864. Quoted by Egon Corti, Maximilian and Charlotte, pp. 399-400.

53 Frossard to Napoleon, 1-5 April 1864. AN: 400AP 62, Archives Napoléon.
} 
When approached by Frossard Maximilian claimed he had not been given all the details before he went to Paris, and his honour as an Archduke, a husband and son made him act as he did. Frossard reminded him that beyond his own private honour there was his political honour owed to Napoleon, France and the world. Maximilian said he recognised this, as did his wife, but he could not help being anxious about the future for his wife, and the children he hoped to have in Mexico. As far as the Archduchess was concerned, Frossard commented to Napoleon that she seemed as upset as the Archduke, but all the same she was very decided about becoming the Empress of Mexico and unconcerned about her eventual rights to the crown of Austria.

Napoleon was becoming more anxious, and before he received this account from Frossard he sent him a telegraph saying:

Une décision prompte est indispensable. La nouvelle de l'indécision fera naître des complications au Mexique. Déjà, en Angleterre, la Bourse fait des difficultés pour le nouvel emprunt. Toutes ces questions de famille auraient dû être réglées d'avance. On ne peut, sans grand inconvénient, laisser un peuple en suspens, vis-à-vis de grandes difficultés et l'escorte dans les Terres-Chaudes en proie aux atteints de la fièvre jaune. ${ }^{54}$

Meanwhile Frossard learned that all the difficulties emanated from the repeated and firm advice of King Leopold of Belgium, the father of Princess Charlotte. He had earlier impressed on Maximilian the need to have in writing Napoleon's commitment to the gradual withdrawal of French troops so that if things went badly Napoleon could not suddenly withdraw them. ${ }^{55}$ Maximilian showed Frossard a letter in which Leopold had told him not to give in over his claim to the Austrian throne, but to treat tactfully the Mexican deputies, who were waiting to receive his official acceptance, while the issue was being resolved. The obstinacy of this influence seemed very offensive to both Napoleon and Franz-Josef, Frossard told Maximilian, and he added to Napoleon that he felt the Prince was entirely dominated by his father-in-law. Frossard then expressed his personal opinion of Maximilian which should have perhaps sounded a waming to

\footnotetext{
${ }^{54}$ Napoleon to Frossard (Telegraph), 5 April 1864. Quoted by Émile Ollivier, L'Empire libéral, Vol. 6, p. 585.

${ }^{55}$ Leopold to Maximilian, 4 February 1864. Quoted by Egon Corti, Maximilian and Charlotte, p. 317.
} 
Napoleon, but previous impressions had been so different and it was really too late to consider alternatives. Frossard said:

Avec une intelligence distinguée et un esprit cultivé, il n'a pas assez de caractère, et si j'osais le dire, de fermeté d'âme. Sa pensée est tout à des éventualités chimériques; il tourne trop vers l'Europe ses regards d'avenir, et ne me semble pas avoir assez de confiance dans la grande entreprise qu'il va faire. ${ }^{56}$

Count Fleury also was concerned about Maximilian and said he had told Napoleon he had heard that Maximilian was "very fickle in character" and that he focused more on trivialities than important issues. For example, even though he was not yet emperor he had spent a year deciding on the uniforms for his court and the livery for his household. ${ }^{57}$ Napoleon's own impressions, however, seem to have been favourable.

Try as he might, Frossard said he had been unable to get the Archduke to fix a day for his official acceptance, and he had to write to him at Miramar, his home, to announce the arrival of a M. Herbet who was bringing the treaties which needed to have his signature. Frossard told Maximilian that he knew quite well that he had decided to accept and it was not possible to defer any longer the written assurance that was awaited by both Napoleon and Mexico. Maximilian replied with a friendly note but indicated only vaguely either the following Saturday or Sunday to receive the Mexican deputation. When he received the above telegraph from Napoleon, Frossard showed it to Maximilian and impressed the problem of the troops waiting longer in the unhealthy zone to escort him to Mexico City. Maximilian replied that he was waiting for Charlotte to return from Vienna, but he agreed to accept the deputation on the Saturday and leave for Rome and Mexico on the Sunday. Maximilian finally gave his formal commitment to the Mexican deputies and signed a Convention with France on the appointed day, but his departure was delayed several days because he took himself to his room suffering a mysterious illness brought on, it was surmised, by his anxiety. This did not augur well for the

\footnotetext{
${ }^{56}$ Frossard to Napoleon, 7 April 1864. AN: 400AP 62, Archives Napoléon.

${ }^{57}$ Général Comte Fleury, Souvenirs du Général Comte Fleury, Vol. 2, pp. 265-267
} 
future, but of course nobody was to know at this point just how inept Maximilian was to prove to be, although many had expressed their doubts about his capabilities.

Napoleon has been condemned for putting pressure on Maximilian, and accused of wanting only to serve his own interests, but it is difficult to support that condemnation. Napoleon has been shown to have been the most cautious of all the interested parties about imposing a monarchy, and the most anxious to ensure that it was the will of the people. He did not exert any pressure on Maximilian until after he had concluded lengthy negotiations with him in Paris, during which Maximilian had obtained from the Emperor all that he wanted, especially in relation to payment of the indemnity of Mexico to France, the number of French troops to remain in Mexico, and other concessions that Metternich had thought would be impossible. ${ }^{58}$ But there is another question to be considered, and that is whether Maximilian should be completely exonerated while Napoleon is condemned. Once the Archduke left Paris it was accepted by Napoleon that he was committed to go, and certainly his negotiations had never revealed the possibility of his reneging. Napoleon's anxiety was therefore understandable. Ollivier, however, sympathised with the unfortunate Prince whom he believed to be subjected to undue pressure by the two Emperors, the Mexican envoys and "a wife consumed with ambition, who was not going to let an imperial crown fall from her head."59

Arguments that Napoleon wanted to finish with Mexico because of the crises that were looming in Europe can only be partially substantiated. Most of the issues had been on-going for some time, except for the Danish-German question which only became urgent with the death of the Danish king in the previous November. A. and K. Hanna said that the rejection of Napoleon's Congress had caused him to try to "get the Mexican Empire on its feet as quickly as possible so that the onus would be shifted to the shoulders of the new ruler." If the new Emperor was successful in gaining control over most of Mexico and having his Empire accepted by the United States, they said,

\footnotetext{
${ }^{58}$ Metternich to Rechberg, 14 March 1864. H. Salomon, "Le Prince Richard de Metternich", p. 534-535.

${ }^{59}$ Émile Ollivier, L'Empire libéral, Vol. 6, p. 586.
} 
Napoleon could withdraw his troops and turn his attention to Europe. ${ }^{60}$ Yet the rejection of his Congress could equally be claimed as a reason for maintaining his interest elsewhere, not freeing himself of it. There were many who believed Napoleon lost interest in everything when his Congress was rejected, but although he was badly affected by it his absence from active involvement in politics was only momentary. It will be seen that his interest in Mexico continued but his efforts after Maximilian's departure were directed towards encouraging the development of Mexico's resources and army so he could reduce France's involvement as he always intended.

The English, however, were the most cruel of Napoleon's critics, for many of them, led by their Prime Minister, Palmerston, were never able to rid themselves of the fear of France that had been generated by the first Napoleon. No matter what Napoleon III did, including initiating the Commercial Treaty with England in 1860, he was never able to convince them that their fears were unfounded. It will be seen in the next chapter that this fear of Napoleon's intentions towards England and Europe formed the basis for England's policy towards France and for rejection of Napoleon's proposals for congresses. One English journalist echoed this fear when he said of the Mexican campaign:

The enterprise ... has successfully engaged the thoughts of the French people during a period when the Emperor found it advisable to remain at peace in Europe. France is still in a condition in which the stimulus of military action abroad is requisite to keep her quiescent at home. The Emperor's Mexican idea has served this purpose as well as others. And Europe has been thankful that the French have been amused otherwise than at her expense. 61

Writing this shortly after the arrival of Maximilian in Mexico, Patterson commented that now that France's direct action in Mexico was coming to an end and there was unrest in Europe, the Continental Powers should be wary of what his intentions might now be in Europe.

60 A.J. and K.A. Hanna, Napoleon III and Mexico, pp.110-111.

${ }^{61}$ R.H. Patterson, "The Napoleonic Idea in Mexico", Blackwood's Magazine, Vol. 96, July 1864, p. 83. 
But Napoleon did not need to control Mexico, as he did not need to control Europe, to fulfil what has been called la grande pensée de l'empire, because the vision that he had was based on the concept of a world free of trade barriers, and where borders did not really matter if nations could resolve their difficulties at a conference table instead of with arms. Mexico was an opportunity seized upon at an appropriate time on the path to fulfilment of that vision which was developed from his interpretation of the intentions of his uncle Napoleon I, and which he called "Napoleonic Ideas". These ideas became, essentially, his foreign policy. 


\section{CUbapter 8}

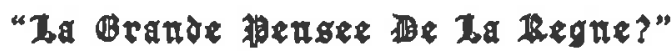

In the memory of many, contemporaries, historians and lay observers, the most significant thing about the French intervention in Mexico was that it was an overwhelming failure. The question is, do we simply consider the reasons for it being a failure, or is it valid to analyse the intentions of the man who has been given the credit by some for a great idea, and the blame by most for its failure and the death of Maximilian? I do not believe that Napoleon should be dismissed as just a man of great ideas who was totally impractical, or even inept, as some would have, but that those ideas and the reasons they did not come to fruition should be examined as closely as the events themselves that contributed to the failure of the venture. Napoleon himself gave support to such a premise in the preface to his History of Julius Casar when he wrote:

It is not a minute analysis of the Roman organisation which will enable us to understand the duration of so great an empire, but the profound examination of the spirit of its institutions; no more is it the detailed recital of the most trivial actions of a superior man which will reveal the secret of his ascendancy, but the attentive investigation of the elevated motives of his conduct. ${ }^{1}$

The extent to which Napoleon likened himself to Cæsar, if at all, is not certain, but the principle he proclaimed here can be just as appropriately applied to his own empire.

The campaign was called la grande pensée de fa règne by Eugène Rouher and the term has been used, often derisively, by historians when discussing its failure. Many of them have oversimplified the concept and claimed that Napoleon was obsessed with the idea of imposing a Latin Catholic bloc in the Americas, and yet there are more arguments to refute this view of Napoleon's idea than there are to support it. To understand this, and consider the validity of the various arguments, the venture needs to be placed within the overall context of Napoleon's foreign policy. Many have argued that he did not have

\footnotetext{
${ }^{1}$ Napoleon III, History of Julius Casar, 2 Vols. (London, 1865), Vol. 1, p.xii.
} 
a policy, but it can be shown that he was in fact faithful to the ideas expressed in his youth in Des Idées napoléoniennes, his interpretation of the intentions of the first Napoleon regarding government and foreign relations, as well as in Rêveries politiques and other political writings. These ideas formed the basis of Napoleon III's foreign policy and his actions in Mexico must be looked at in the context of these ideas, and not in isolation. It can then be seen that Mexico was indeed part of an overall vision, but not in the narrow sense given it by historians such as Christian Schefer and A. and K. Hanna.

An integral part of Napoleon's policy was a firm alliance with England, and the sincerity of his endeavours in this direction can be seen in numerous instances throughout the $1850 \mathrm{~s}$ and $1860 \mathrm{~s}$. There is more than enough evidence to refute any claims that he was looking for an opportunity to invade England or to dominate Europe, yet the senior politicians in England always remained suspicious of his intentions in both these directions. It was this suspicion that was behind England's rejection of Napoleon's proposals for congresses to resolve the problems of Europe, and England's influence with other govemments meant none of them eventuated. Mexico was a further opportunity to cement France's alliance with England, but misunderstood and disbelieved regarding Europe, there was little chance that Napoleon would gain support from England to extend his ideas beyend Europe.

In the final analysis, although history has condemned Napoleon over the Mexican campaign, it will be seen that his intentions need to be considered carefully and that he does not deserve to be labelled as "a knave or a fool" because he failed. Events of the last eighty years, and more especially of the last twenty, have shown that his ideas were not so Utopian, just far beyond the nationally focused vision of the majority of his contemporaries. As Baron d'Ambès, a close friend, said, "on every hand he met with opposition, selfishness, the lust of battle. The day of arbitration was not yet come. He 
anticipated it."2 His intentions, however, were in the hands of others, and in the case of Mexico, at a great distance from France, and at the mercy of their interpretations and actions. In 1864 these others included Maximilian and Bazaine.

Maximilian arrived in Mexico in May 1864, but after only two months the Mexican people had begun to be disillusioned by his inactivity. To their consternation he left the capital to explore the country before he had established a ministry and without having issued any decrees. The financial measures he had undertaken were only expedients, more often than not ill advised, and the most fundamental issue of the nationalised property of the clergy had been the subject of a series of regulations, each more impractical than the others, according to notes made by General Castelnau who was sent by Napoleon to assess the situation in late 1866 . He wrote:

Pour avoir gaspillé un temps précieux, accumulé des fautes sans nombre, passé à côté du programme que lui traçaient les conditions mêmes de son avènement, l'empire, dès les premiers jours de l'année 1865, se trouva irréparablement condamné. Maximilian, si bien accueilli à son entrée dans Mexico, le 12 juin précédent, était arrivé, dans un délai paradoxalement bref, à la plus complète impopularité. Le sentiment public à cet égard se traduisait tout haut par un jeu de mots cruellement expressif. 'Ce n'est pas un empereur que nous a envoyé la France, disait-on parmi le peuple, c'est un empireur.' 3

Castelnau's comments about lack of decisive action in the early months were supported by the correspondent of The Times who reported in October 1864 that many were concerned about Maximilian's absence from the capital and were "beginning to complain of a want of more decided action." He did suggest, however, that these feelings may be a result of having seen so many leaders before Maximilian furiously signing decrees in their early days because of the constant fear that they would very shortly be ousted by another revolution. He felt the people would soon appreciate Maximilian's decision to get to know the country and the people and their resources before making decisions, and

\footnotetext{
${ }^{2}$ Baron d'A mbès, Intimate Memoirs of Napoleon III: Personal Reminiscences of the Man and Emperor, 2 Vols. Edited and translated by A.R. Allinson (London, n.d.), Vol. 2, p. 184.

${ }^{3}$ Louis Sonolet, "L'Agonie de l'Empire du Mexique: D'après des lettres et des notes inédites du Général Castelnau", La Revue de Paris, Vol. 34, 1 August 1927, p. 594.
} 
that when he realised the Mexican commissioners he had left in charge in his absence had achieved nothing he would take action. ${ }^{4}$

The early news from Mexico had indicated that the prosperity of the country, at least in those areas controlled by the French, was improving. The Paris correspondent of The Times reported that the receipts at the Vera Cruz custom house had increased every month but one since the beginning of the year, although he added that the reports regarding the amount of opposition still to be suppressed in the country were contradictory. ${ }^{5}$ Bazaine did not help in this respect as he reported the continued successes of the French army without advising that the disbanded fragments of Juarez's supporters always reformed and came back into the battle somewhere else. ${ }^{6}$ On the other hand, a report, dated 24 July 1864, from a correspondent of the New York Herald, claimed that armed opposition to Juarez was increasing daily and far outnumbered those still supporting him. ${ }^{7}$

In the light of such optimistic reports, and unaware of Maximilian's inactivity, Napoleon wrote to Bazaine in August emphasising the need to develop the indigenous army so the French could leave as soon as possible. It had been assumed that Maximilian would have encouraged this task and begun managing the resources of Mexico so that France could gradually withdraw both its military and financial aid. In November 1864 he wrote to Maximilian impressing the need for his government to establish its credit in the light of bonds issued in Paris for a new loan which would provide a considerable sum for him by early 1865 . He added that it was necessary for Maximilian to have a sound bank well established in Mexico as leading bankers in Paris and London had agreed to "place themselves at the head of this establishment." $\mathrm{He}$ continued with some cautionary advice which seemed to recognise that Maximilian might

\footnotetext{
${ }^{4}$ The Times correspondent, 11 October 1864. Printed in The Times, 19 November 1864.

${ }^{5}$ The Times, 7 July 1864.

${ }^{6}$ Egon Corti, Maximilian and Charlotte, p. 439.

${ }^{7}$ Although this report was not printed in The Times until 11 October 1864, it would still have been encouraging news in Paris.
} 
be feeling some unease in his new position, but he had no way of knowing how indecisive Maximilian was to prove to be. He said:

... I venture to say that in labouring to find a new empire it is impossible to arrive at perfection all at once; the measures that one takes always offer certain advantages accompanied by certain disadvantages; the cleverness of the sovereign consists in seeing whether the former outweigh the latter. ${ }^{8}$

Napoleon's advice about developing the resources of Sonora and other areas of Mexico was incomprehensibly rejected by Maximilian. A. and K. Hanna commented on this action by saying:

The importance of this rejection lies in the insight it affords into the Austrian's own thinking on Mexico. He had just underwritten a staggering debt for his unknown realm whose chief difficulty had been financial confusion and bankruptcy. At the same time he denied what at the moment seemed the quickest means of discovering new wealth. ${ }^{9}$

While Napoleon had every reason to hope that the new empire would soon begin to be independent, the reports that ardixed in Paris in 1865 began to present a very confusing picture. By mid 1865, both Napoleon and Marshal Randon were greatly concerned at the lack of progress in the development of Mexico's resources, and particularly that Maximilian's government seemed to think that the French government would continue to support the country indefinitely. On the other hand, while Bazaine's military reports indicated that the pacification of the country was proceeding very well, he still requested that more troops be sent, in anticipation of the losses that would occur in the next few months due to both sickness and battle. Randon pencilled a succinct "non" on Bazaine's request of 22 April, and a more lengthy comment that there was no intention of sending reinforcements, on his request of 27 May. Firstly because it was intended to leave Mexico as soon as possible, but no doubt also because he saw no need for them in view of the favourable military reports. Randon was compelled, however, to raise with Bazaine the contradictory impressions that his political and military reports and personal letters conveyed. The political reports seemed to say that there was no chance

\footnotetext{
${ }^{8}$ Napoleon to Maximilian, 16 November 1864. Quoted by Egon Corti, Maximilian and Charlotte, pp. 853854.

${ }^{9}$ A.J. and K.A. Hanna, Napoleon III and Mexico, pp. 126-127.
} 
of regenerating the country under the empire, while his other reports and letters showed great progress being made, at least as far as control of the country was concerned.

Randon said both he and the Emperor were moved to wonder if they were written or influenced by the same person, but for whatever reason, they chose at this time to accept the more optimistic outlook. ${ }^{10}$

That optimism was soon to dissipate, however, in the light of the negative views of officers returned from Mexico, and also expressed in personal letters from Mexico. When advised of these Bazaine wrote to Randon that he had told his men to be very reserved in what they had to say or write, but that Randon should know how much the spirit of criticism was inherent in the French nature and how little the French liked to have their natural vivacity suppressed. He concluded that their negative opinions could not be considered valid because they were only formed on their own limited contact with Mexicans and foweraers and they could not have an overall picture of the real situation. His current view was that Paris needed to be patient and realise that the empire could not be expected to be self sufficient in such a short time, even if much of the blame was due to lack of firmness and practicality on the part of Maximilian. He assured Randon that things would progress quickly after a rail link was forged between Vera Cruz and Mexico City, although he had never expressed such conditions before. ${ }^{11}$

What course was now open to Napoleon when both he and his government had anticipated being able to begin withdrawing from Mexico? Certainly the chambers would not sanction an increase in the budget for Mexico after their reserved passing of the supplementary budget in November 1863, and Napoleon was reminded in August 1865 of the feelings of the chambers and of the people, by one of his Ministers without portfolio, and long-time friend, Magne. Magne remarked that while it was accepted that France's intentions in Mexico had been noble, it was now up to the new government there to free the country from anarchy. Neither the people nor the majority of the Corps

\footnotetext{
10 Randon to Bazaine, 28 June 1865. Quoted by Paul Gaulot, L'Expédition du Mexique, Vol. 2, pp. 137-138.

${ }^{11}$ Bazaine to Randon, 27 July 1865 . AMG: $\mathrm{G}^{7} 2$.
} 
législatif would sanction sending more troops to Mexico, nor vote more money for the expedition. He believed that if there was a universal feeling about the situation it was that their first setbacks had been gloriously avenged, their honour was safe and their interests satisfied, so there was no need to prolong their occupation. Two other issues added to the desirability of leaving as soon as possible, and they were the possibility of conflict with the United States, and the state of things in Europe, particularly in Spain and Germany. ${ }^{12}$

These observations, however, only added to Napoleon's firm desire to withdraw from Mexico, they did not influence him to make that decision. He wrote in determined fashion to Maximilian in August 1865 that it was imperative that he develop a strong government that would be accepted by America, and "should cause no embarrassment to France, who is making so many sacrifices for Mexico." 13 Maximilian had apparently applied himself industriously to an incessant study of the urgent reforms needed, had signed numerous decrees and submitted countless projects to a close study, but little had been achieved. ${ }^{14}$ Napoleon's patience was overstretched by a report from Bazaine at the end of October which showed that things were not going well. Napoleon told Bazaine that France could no longer remain in such a situation of uncertainty with its prolonged demands on their finances, and he had to make an "energetic resolution". His impatience was obvious in his following words:

Il faut que l'Empereur Maximilien comprenne que nous ne pouvons rester indéfiniment au Mexique, et qu'au lieu de bâtir des théâtres et les palais, il est essentiel de mettre de l'ordre dans les finances et sur les grandes routes. Qu'il sache bien qu'il sera beaucoup plus facile d'abandonner un gouvernement qui n'a rien fait pour pouvoir vivre que de le soutenir malgré lui. 15

In pursuance of these comments, Napoleon advised his two chambers in January 1866 that as Mexico was now governed by "a regular power which was ready to fulfil its

\footnotetext{
12Magne to Napoleon, 12 August 1865. AN: 400AP 62, Archives Napoléon

${ }^{13}$ Napoleon to Maximilian, (no precise date given) quoted by Joan Haslip, Imperial Adventurer, (London, 1974, (c) 1971), p. 314.

${ }^{14}$ Comte Émile de Kératry, “Le Mexique et les Chances de Salut du Nouvel Empire”, R.D.M., Vol. 65, 15 September 1866, p. 451.

15 Napoleon to Bazaine, 29 November 1865. Quoted by Paul Gaulot, L'Expédition du Mexique, Vol. 2, pp. 210-211.
} 
commitments, and respect foreigners and their property in Mexico", he would soon be able to advise the date by which the expeditionary forces would be withdrawn - after necessary arrangements were concluded with Maximilian. ${ }^{16}$ He naturally did not confide his concern about the slow development of the self sufficiency of the Empire.

The situation in Mexico was beyond Napoleon's control at such a distance, and he was not to succeed in effecting the withdrawal until after he had sent one of his most trusted generals, General Castelnau, to Mexico in September 1866 to give him a thorough assessment of the situation of the Mexican Empire. In the meantime he was bombarded with confusing reports from Bazaine which were boringly repetitive, occasionally adding how much better all would be when the railway was completed, or pressing the need to augment the number of troops in case of increased threat from American filibusters in the north, or from the United States themselves. ${ }^{17}$ There were also contradictory reports from Maximilian and Bazaine each of whom blamed the other for the lack of progress in Mexico. While Bazaine complained of Maximilian's lack of activity he in turn was accused of using available funds and materials to support the French army instead of organising a Mexican army. Napoleon was not moved by Bazaine's requests for more troops and when the Empress Charlotte came to Paris in August 1866 in a desperate bid to get Napoleon to continue his support of the Empire, Napoleon could only tell her that they had done their best for Maximilian and could do no more, except to help him to leave. ${ }^{18}$

Castelnau was instructed to determine if the imperial government could sustain itself after the departure of the French, and if it could not he was to encourage Maximilian to abdicate. At the same time he was concerned for the fate of Mexico and did not wish to see the country abandoned once more to anarchy. If this seemed likely Castelnau was

\footnotetext{
${ }^{16}$ Napoleon to the chambers, January 1866. Exposé de la Situation de l'Empire Présentée au Sénat et au Corps Législatif, January 1866, Vol. 4, p. 227.

17 Bazaine to Randon, 28 January 1866. AMG: $\mathrm{G}^{7} 3$.

${ }^{18}$ Comte Fleury, (ed.), Memoirs, Vol. 2, pp. 120-121.
} 
to propose that Bazaine remain for a short time as dictator while the people decided the leader and kind of government they wanted. He added:

Mon seul but, mon seul vœux est de ne pas voir se perdre les germes de civilisation qu'a pu semer dans ce pays, auquel tant d'intérêts nous rattachent et que j'ai voulu, à un jour donné, sauver de son propre désordre, la présence pendant cinq années du drapeau et de l'esprit français. ${ }^{19}$

While Napoleon's instructions to Castelnau show disappointment in what had transpired in Mexico, they also remind us that his aims had been, and were still, humanitarian. If they had been purely self-seeking there would have been no need for him to reiterate this to Castelnau.

Maximilian, though, proved to be just as indecisive about abdicating as he had been about all his actions in Mexico. In November Castelnau reported that he was ready to leave Mexico, but in the ensuing weeks many of Maximilian's associates, including Bazaine, who apparently had personal interests he wished to maintain in the country. tried to convince him that the Empire still had some chance of surviving. After receiving Castelnau's letter of 9 December detailing Maximilian's vacillations and all the intrigues to persuade him to remain in Mexico, Napoleon sent a cable to Castelnau saying:

Reçu dépêche du 9 décembre. Ne forcez pas l'Empereur d'abdiquer mais ne retardez pas le départ des troupes. Repatriez tous ceux qui ne voudront pas rester. La plupart des navires sont partis. ${ }^{20}$

Bazaine had reportedly told Maximilian that if he decided to remain in power Napoleon would continue to support him with troops. ${ }^{21}$ However, he later said that he had only told Maximilian that the Foreign legion and those French soldiers put at the disposition of the Mexican government would remain, and that he was authorised to say this until a telegraphic despatch from Napoleon, dated 13 December ordered him to repatriate the

\footnotetext{
${ }^{19}$ Napoleon to Castelnau, 15 September 1866. Quoted by Louis Sonolet, “L'Agonie de l'Empire du Mexique”, pp. 600-601.

20 Napoleon to Castelnau, 10 January 1867. Transatlantic cable. AN: 400AP 42.

${ }^{21}$ Letters provided to Castelnau testifying to Bazaine's actions, dated 3 and 5 December 1866 . Quoted by Louis Sonolet, "L'Agonie de l'Empire du Mexique", pp. 869-870.
} 
Foreign Legion and all French soldiers. ${ }^{22}$ Despite his denials Bazaine did continue to press Maximilian to stay.

In the meantime Maximilian advised Castelnau that he did not wish to maintain his crown and was ready to set it aside but wanted to do it honourably for himself and usefully for the country. Because he had been called by the country to be its Emperor it was up to the people to decide whether he should leave. He had decided to convoke a national congress and propose an armistice which would allow all the parties to come together to decide the destiny of the country. He would abide by their decision whatever it might be. Castelnau advised him that this might have been a reasonable suggestion a year ago, but now when his own ministry considered the empire "a noble and chimerical Utopia", and the republicans were in control of most of the country the only thing to do was to abdicate, and spare himself and the country from the disaster that would ensue such an action that Maximilian proposed. Maximilian was unmoved by Castelnau's pleas, however, even when shown a declaration signed by himself, Dano the French Minister and Bazaine suggesting this was the only step to take. Instead he showed them a despatch dated the previous day from Bazaine urging him to keep the crown for the empire was the only solution for Mexico, and he would do all he could to support it. While Castelnau was astounded at Bazaine's duplicity Maximilian said he had been subjected to it for a long time and believed Bazaine was influenced by his Mexican wife and her family. Regardless, he was committed to his decision to convene a congress and asked Castelnau if he might ask the United States to mediate by urging Juarez to be involved in the congress. ${ }^{23}$

No longer able to help him the French troops began leaving Mexico City on 5 February 1867, while Maximilian remained to try and salvage his Empire. Maximilian had made his decision, urged on by the Conservatives who knew once he left they would be mercilessly persecuted by Juarez. However, unknown to his generals, who managed

\footnotetext{
22 Bazaine to Randon, 10 January 1867. AN: 320AP 2, Bazaine.

${ }^{23}$ Castelnau to Napoleon, 28 December 1866. Quoted by Louis Sonolet, "L'Agonie de l'Empire du Mexique", pp. 879-882.
} 
to win some small battles against the Liberals, Maximilian intended to negotiate with Juarez to bring about peace under a government that might be arranged between the two of them. But Juarez refused to negotiate and Maximilian continued to fight until May when he decided perhaps it would be better if he tried to leave the country. But his plans were thwarted by one of his most trusted generals who betrayed his plans to the Liberals who demanded his unconditional surrender. A request to Juarez that he be allowed to leave the country was refused and he and two of his generals were subjected to a courtmartial which sentenced all three to death. At no time would Juarez meet Maximilian, and on 19 June 1867 he was executed by firing squad. ${ }^{24}$ Thus was brought to an end what many had called the dream of the Emperor Napoleon, who was then to be accused of being responsible for the fate of Maximilian and his Empire.

In the immediate aftermath of the collapse of the Mexican Empire there were many claims that the greatest contributing factor to its downfall was the conclusion of the American Civil War, and Napoleon's fear of a war with the United States. The American press particularly, liked to convey the idea that Napoleon had decided to withdraw from Mexico after their Foreign Secretary, Seward had put pressure on France by writing to Napoleon's Minister in Washington, in December 1865. General J.

Watson Webb, American Ambassador in Brazil, however, had had discussions in Paris with Napoleon in November that year, and knew that he had decided to withdraw from Mexico well before Seward had written to Montholon on 5 December. In April 1866 he wrote a letter to Napoleon in which he accused Seward of unjustly giving the impression that he had influenced the French with his letter to Montholon, when he had known the day before he wrote it that Webb had already told the President of Napoleon's decision. ${ }^{25}$ But even before this Napoleon had advised Drouyn de Lhuys to write to Montholon in Washington in response to a despatch received from him in October 1866.

\footnotetext{
${ }^{24}$ Egon Corti, Maximilian and Charlotte, pp. $765 \mathrm{ff}$.

${ }^{25}$ Webb to Napoleon, 27 April 1866. AN: ABXIX 172.
} 
This was to be in the form of an official despatch "qui prouve que nous avons pris nos résolutions à l'égard du Mexique sans y être amené par une pression des états unis, et par conséquent avant l'arrivée du Général de Castelnau." He was to tell Montholon that the Emperor had intended to withdraw the French troops in three convoys, the last leaving in November 1867, but the news from Mexico was so bad that he did not want to leave a small number of troops exposed and isolated at such a great distance from France. And this was why he had sent Castelnau to tell Maximilian that if he wished to remain in Mexico he could no longer count on the support of France. ${ }^{26}$

The argument that it was pressure from the United States and fear of war that forced Napoleon to withdraw is really not that strongly supported. Correspondence from Bigelow, the American Ambassador in Paris, after a discussion with Drouyn de Lhuys in October 1865 also shows that France had decided to withdraw, but was hoping that the United States would be prepared to recognise Maximilian's government. A. and K. Hanna used this discussion to support their argument that Napoleon was looking for an excuse to get out of Mexico. They suggest that Bigelow's comment to Drouyn de Lhuys that if the French troops did withdraw the United States might have to recognise the Empire, gave France the opening to withdraw while saving their prestige. ${ }^{27}$ It is true that Napoleon wished to avoid antagonising the United States, but it was the realisation that Maximilian was expecting the financial and military support of France to continue indefinitely that had most influence on Napoleon. He would not be able to, and did not want to have to, justify continued expenditure in Mexico when he had not intended a prolonged occupation in the first place. When Maximilian decided to stay in Mexico at the beginning of 1867 Napoleon had no choice, for France's sake, but to withdraw his troops and leave Maximilian to do the best he could alone.

Other contemporary views also give an important impression of the reasons for the failure of the Empire. After Maximilian's execution, the French Minister in Mexico,

\footnotetext{
26 Napoleon to Drouyn de Lhuys, 19 October 1866. AN: 400AP 42, Archives Napoléon.

${ }^{27}$ A.J. and K.A. Hanna, Napoleon III and Mexico, p. 153.
} 
Alphonse Dano, wrote to the Foreign Ministry that opposition from the newly united States of America perhaps had most impact on the future of the Mexican Empire. But apart from that, the most serious obstacle to the success of the Empire was Maximilian himself, who "reasoned well and acted entirely to the contrary", not having the common sense to realise he could not live by traditional Habsburg protocol in Mexico. 28 Castelnau's first despatch from Mexico summarised the feelings of everyone associated with Maximilian, including those who had been close to him, and supported the comments of Dano. It said in part:

Ce malheureux prince est condamné sans appel, sa cause est perdue sans rémission et n'est pas discutable. C'est qu'en effet son incapacité absolu qui, dès les premiers jours de son règne, avait alarmé les hommes clairvoyants, est devenue aujourd'hui évidente pour tous. C'est que ses irrésolutions, ses maladresses, ses contradictions, ses dissipations, son inertie surtout lui ont enlevé successivement jusqu'au dernier de ses adhérents. Et pourtant chacun s'accorde à reconnaître que, si difficiles que fussent les circonstances dans lesquelles il a pris le pouvoir, il avait en mains plus de moyens qu'il n'en fallait pour les maîtriser. ${ }^{29}$

General du Barail on the other hand saw the initial cause in the unlimited powers assumed by the Regency which tried to introduce laws that had already been rejected in France, thus severely damaging the credibility of Napoleon's intentions in Mexico. If it were not for their actions, particularly those of Labastida, the various factions may have been reconciled happily under Maximilian and the United States "would probably have resigned themselves to the fait accompli, du Barail believed. ${ }^{30}$

But the Regency and Maximilian only played in the final acts of what was a disastrous venture, and it was events prior to this that determined the inevitable outcome. One contributing factor, the tyranny of distance, was a substantial cause of many of the problems witnessed above. We have already seen how the delays in communication meant many decisions were made in Mexico without the counsel of the government or Napoleon, and there was little that could be done in the aftermath of an action already

\footnotetext{
${ }^{28}$ Dano to Moustier, 1 September 1867. Quoted by A.J. and K.A. Hanna, ibid, p. 304.

${ }^{29}$ Castelnau to Napoleon, 28 October 1866 . Quoted by Louis Sonolet, "L'Agonie de l'Empire du Mexique", pp. 606-607.

${ }^{30}$ Général du Barail, Mes Souvenirs, Vol. 2, pp. 487-488.
} 
taken. The problems of conducting a campaign from a distance had been analysed by Prince Napoleon, cousin of Napoleon III, during the Crimean war when he offered some pertinent advice to his cousin. Admittedly there was a difference between the two campaigns, particularly as the Mexican campaign was not anticipated as a long one, and was not initially expected to be a war of any account, but the following words of Prince Napoleon were just as appropriate to this campaign:

When a war is carried on at such a distance it is not only at an enormous cost in men and money, but, further, the Government is not in a position to direct it owing to the time required for the interchange of communications. From this fact arises the necessity of entrusting the Commander-in-chief with extraordinary powers, which is always dangerous, and of leaving to him the absolute direction of events. ${ }^{31}$

Prince Napoleon went on to comment how difficult it was to find someone worthy and capable of exercising effectively such a responsibility, and the problems caused by the people chosen for that command in Mexico have been well illustrated.

The significance of the roles played by others in this campaign, however, has been played down by both contemporary critics and historians, but the new material I have used, particularly in Chapter 6, shows that much has been missed in this regard. I have shown that Jurien admitted taking decisions opposed to his instructions and accepted responsibility for doing so. I have also demonstrated how much initiative was taken by Saligny and Almonte in directing the actions of Forey. When the Regency was appointed as a result of all their actions, the situation in Mexico was beyond Napoleon's control and events put in train that led to the tragic conclusion of the venture. Should Napoleon perhaps be blamed for having made the wrong choice of personnel? But then how was he to know that his commanders, proven leaders, would interpret his seemingly clear intentions according to their own views? In Chapter 7 it was seen also that independent reports from Mexico, such as those of The Times correspondent, indicated that all was going well for the French. This would have encouraged Napoleon to believe that once

\footnotetext{
${ }^{31}$ Prince Jerome Napoleon to Napoleon, April 1855. Quoted by Ernest d'Hauterive, The Second Empire and its Downfall, p. 78.
} 
Maximilian was in Mexico he need have no qualms about withdrawing his army in the agreed time.

Napoleon could not have anticipated the contrary actions of his envoys but it has been remarked that once Napoleon gave instructions to an agent, in whatever capacity, he was not always aware that his intentions were not being carried out as he wanted.

Mazade, who had observed the government for more than fifteen years, was in correspondence with the Empress Eugénie and wrote to her in 1865 when she was acting Regent, offering advice to the Emperor on the cause of some of his problems and how they might be overcome. He believed many of the Emperor's projects were compromised because of the people who were meant to direct their operation. Many often imposed their own ideas in the implementation of Napoleon's plans and he was not always aware that they were not carried out as he intended. Mazade said:

Forcément, involontairement peut-être, insensiblement, ceux qui exécuten substituent leurs idées, leurs intérêts leurs préoccupations à la pensée de celui qui croit avoir pourvu à tout par une direction générale ou par un ordre. L'Empereur se fait-il par hasard l'illusion que tout ce qu'il dit se fait, que ce qui est de son intérêt, c'est à dire de l'intérêt public, prédomine? Ce serait une singulière méprise. Il faut bien qu'il sache qu'il trouve quelquefois ses ennemis les plus dangereux, d'autant plus dangereux qu'ils sont involontaires, dans les agents eux-mêmes, qui le plus naivement, le plus consciencieusement du monde cherchent avant tout à faire prévaloir leurs vues propres, à se faire une influence, à soigner leur position..$^{32}$

This tendency to put their own mark "involuntarily perhaps" on the interpretation of their instructions has been well illustrated in the Mexican campaign. But what has perhaps been overlooked is the fact that once Napoleon realised that his plans had gone astray, he took firm control to try and ensure that his representatives were very clear about his intentions and that they carried them out. He was not successful in achieving this, but the volume of correspondence between himself and Forey, Almonte and Maximilian shows conclusively that his ideas relating to Mexico were unchanged from his first clear exposé in his letter to Flahault in October 1861. Those who have not studied this correspondence, or who have dismissed it, have tended instead to criticise

32 Mazade to Eugenie, 17 July 1865. AN: ABXIX 174. 
Napoleon for being deceived for so long by Saligny or to assert he and his colleagues were carrying out the "secret" instructions of their Emperor.

While we know now that the venture failed as a result of a series of events which were in many respects beyond the control of Napoleon, it has also been said that it was because he not only lost interest in Mexico after the rejection of his congress proposal, but that his deteriorating health reduced his interest in, and mental ability to cope with, affairs of state. The fact that he spent much of his time writing his History of Julius Casar has been used to support these claims also, and his occupation with it did give rise to much speculation both within and outside France about his health and political intentions. Émile Ollivier remarked:

Comme on ne pouvait se résigner à interpréter aucune de ses actions naturellement et sans y supposer une trame, on vit dans ce témoignage pacifique une habilité inquiétante qui dissimulait des projets belliquex. ${ }^{33}$

He added that it was not "political indolence", as some believed, that led Napoleon to write this history, but that he needed something else to focus on after more than ten years of total responsibility for leading the people of France. He was indeed affected by the rejection of his congress proposal, but after some weeks of appearing angry and morose he has been shown by Echard to have recovered and become actively concerned again about the Schleswig-Holstein question. ${ }^{34}$ His political correspondence, his speeches, his personal letters in these later years, and his writings in exile after the fall of his own empire also show his mind was just as keen as ever, despite continued reports of his deteriorating health and loss of ability to manage affairs of state.

It is difficult to envisage Napoleon himself calling the Mexican campaign "la grande pensée de lex rêgne" when, compared to other foreign matters, particularly those relating to Europe, it occupied relatively little of his time. This can be gathered partly from the comparatively short references to Mexico in Napoleon's annual addresses to the parliamentary chambers, while the reports on the situations in Italy and Poland, for

${ }^{33}$ Émile Ollivier, L'Empire libéral, Vol. 5, pp.76-77.

${ }^{34}$ William E. Echard, Napoleon III and the Concert of Europe, pp. 206-207. 
example, are quite lengthy. The idea of seeing a stable government established in Mexico was indeed part of a "grand idea", but not in the sense seen by many historians and even some of Napoleon's contemporaries. Some believed he was obsessed with the idea of a canal, but if that were so why is there no mention of it in correspondence relating to the development of Mexican resources? The importance of Europe maintaining access to Central America has been discussed, but it has been shown that Napoleon was not the only one concerned about this. His intention to leave Mexico as soon as a government was established also belies an obsession with constructing and controlling a canal in the region.

Another view of "la grande pensée", the imposing of a Latin Catholic bloc and the extension of monarchies into South America, is too simplistic and not supported by the facts. Why would Napoleon insist on the involvement of England in the enterprise if his idea was to strengthen the Latin culture and suppress the influence of the Anglo-Saxons to the north? It has already been seen that he was not prepared to support the clergy in Mexico, and his commanders had instructions to provide places of worship for the Protestant faithful. There is also little evidence to support claims by Perkins and A. and K. Hanna that he intended to substitute monarchies for the republics in South America, other than in the publication of Hidalgo's letters referred to by Mazade. ${ }^{35}$

Others who have analysed the Mexican venture in terms of "la grande pensée" have said that its failure was inevitable because if the ineptitude of Napoleon. Principal among such critics was Schefer, who blames him for not having enough information about either the natural resources of Mexico or its political traditions. The enterprise was based solely on distant hopes and unverified assertions which became for Napoleon "articles of faith", according to Schefer. He supported this assertion with a scathing analysis of Napoleon's intellectual abilities:

Napoléon III a été souvent qualifié de visionnaire; il l'est réellement, dans toute la force du terme, et au point de ne plus savoir lui-même s'il constate ou s'il imagine. Il est radicalement incapable de séparer le rêve de la réalité.

${ }^{35}$ See A.J. and K.A. Hanna,Napoleon III and Mexico, pp. xiii-xiv and 303. 
Les hypothèses qu'il a forgées deviennent pour lui des vérités démontrées et les fictions qu'il évoque lui masquent les obstacles. Des doutes ne l'effleurent donc que rarement. Le succès final lui paraît toujours certain. Et il ne songe pas un instant que ses soldats s'aventurent peut-être au Mexique, à la poursuite d'un mirage. ${ }^{36}$

Schefer admitted that much of the information Napoleon received was wrong or deliberately misleading, but he was culpable for not verifying it. Yet the information given him by Saligny was confirmed initially by opinions from Wyke, and later by those of the Belgian and Prussian envoys and the correspondent in Mexico of The Times. Schefer went even further in his criticism of Napoleon adding that if he seemed to be hesitating about a decision it was not because he was considering and reflecting on what he was told, because he hardly knew how to reflect. He continued in similar vein:

Critiquer ou approfondir, pour prendre ensuite une décision raisonnée, exige un travail qui lui répugnait, car son intelligence nébuleuse et désordonnée était, par surcroît, d'une indolence extrême. S'informer méthodiquement des affaires mexicaines, prescrire des enquêtes et confronter leur résultats eût été besogne dépassant ses forces. 37

These conclusions are extremely harsh and Schefer provided nothing to support them, although he probably drew on the writings of contemporary critics and opponents of Napoleon.

There are others, however, who give a far different view of the personality and abilities of this apparently enigmatic man. Ernest d'Hauterive who published the letters of Napoleon III and Prince Napoleon, said he

wore the appearance of irresolution, because he concealed his will.

Extremely good hearted, of a kindness of disposition exaggerated in the head of a State, and of a patience which nothing could wear down, he knew how to wait; and, because he was master of himself, concealed his impressions, reflected at great length, and did not yield to first impulses, he was accused of indecision. ${ }^{38}$

Napoleon himself commented to his friend d'Ambès that people often gave him advice on what to do and "I take note and I reflect, and consequently, I never come to any

\footnotetext{
${ }^{36}$ C. Schefer, La Grande Pensée, pp. 253-254.

37 Ibid., pp. 260-261.

${ }^{38}$ Emest d'Hauterive, The Second Empire and its Downfall, p. 10.
} 
sudden determination. That is the whole art of politics." 39 Count Fleury in his memoirs said that Napoleon was always willing to listen to the advice of others and even change his mind on the basis of that advice, but unfortunately many of his Ministers and aidesde-camp were too timid to give advice when it may have prevented him committing an error ${ }^{40}$ Émile Ollivier also confirmed Napoleon's habit of carefully considering all sides of the situation before deciding to act:

Avant de s'engager il pesait lentement, mûrement le pour et le contre, embrassait les divers aspects de la situation, parfois passait, pour un instant, avant de se fixer, d'un parti à l'autre: c'est ce que les historiens 'qui n'ont jamais mis le nez aux conseils' ont appelé ses hésitations. ${ }^{41}$

The inability of many of his acquaintances and foreign diplomats to come to terms with Napoleon's reflective nature, demonstrated by his silences and lack of positive response to their ideas, and partly a result of his years as a conspirator, led to inevitable conjecture about his ideas and intentions. In particular his foreign policy has been seen as inconsistent and often decided on a whim.

Some understanding of the apparently contradictory nature of Napoleon's policy and behaviour can, however, be gained by studying not only Des Idées napoléoniennes, but many of the writings of the young Louis Napoleon. It is in them that Napoleon's "great idea" is apparent, and one can speculate on how well it would have served the world if it had been allowed to succeed. Stuart Campbell remarked:

Historians have attributed the seemingly mysterious and contradictory policies of the Second Empire to the unpredictable character of its Emperor. The fact is that few pretenders have so thoroughly advertised their plans before taking power, and Napoleon III remained amazingly true to the proposals of Louis Napoleon. ${ }^{42}$

Accepting this is essential to realising what Napoleon was trying to achieve. In writing Des Idées napolóniennes, Louis Napoleon was interpreting what he saw as the policy of the Emperor Napoleon, and he wished to see it brought to fruition. This policy was

\footnotetext{
${ }^{39}$ Baron D'Ambès, Intimate Memoirs, Vol. 1, pp. 399-400.

${ }^{40}$ Comte Fleury, Souvenirs, pp.52-53.

41 Émile Ollivier, L'Empire libéral, Vol. 3, pp. 77-78.

${ }^{42}$ Stuart L. Campbell, The Second Empire Revisited, (New Jersey, 1978), P.2.
} 
fundamentally the founding of "a solid European association by basing his system upon complete nationalities and upon general interests fairly satisfied". This would have resulted in a European code and court of appeals, uniform coins, weights and measures, and eventually national interests would have given way to European interests and, Louis Napoleon added,

l'humanité eût été satisfaite; car la Providence n'a pu vouloir qu'une nation ne fût heureuse qu'aux dépens des autres, et qu'il n'y eût en Europe que des vainqueurs et des vaincus, et non des membres réconciliés d'une même et grande famille. ${ }^{43}$

Ollivier defined the policy of Napoleon III himself as "that of nationalities", and while he did not refer to Des Idées napoléoniennes when he did so, he showed that it embraced the principles of the 1848 Revolution. He referred to a pre-1848 speech of Thiers calling for the union of Italy; another by Cavaignac in May 1849 calling on the Minister to safeguard the independence and liberty of the people; and the order of the day of 24 May 1848 proclaiming "the future politics of France: close ties with Germany, reconstitution of an independent Poland, enfranchisement of Italy."44 Napoleon III's efforts to convene European congresses are testimony to his intention to implement both his uncle's policy and those principles of 1848 described above, but his writing on a canal in Nicaragua illustrates how he saw that policy extended to encompass the world. It was seen in the Introduction that Napoleon believed prosperity could be achieved only by removing all the barriers that separate people. Improved communications and commerce were now the ways to bring nations closer together, and an essential element in bringing about unity was the lowering of trade barriers. It was this belief that was behind his conclusion of a commercial treaty with England and, despite the work done by Chevalier in concluding the detail, both Rouher and Cobden were adamant that the idea was entirely Napoleon's.

These ideas were also reflected in many of Napoleon III's speeches, writings and discussions during his reign, and they remained remarkably consistent. In his address to

\footnotetext{
${ }^{43}$ Napoleon III, "Des Idées napoléoniennes", p. 158.

${ }^{44}$ Émile Ollivier, "Napoléon III: Son dessin international", p. 50.
} 
the Legislative Body in 1854 he declared that "the era of conquests is over, and cannot return; for it is not by extending her territorial boundaries that a nation in our days can be honoured and powerful; it is by placing itself in the lead of generous ideas, by causing everywhere the rule of law and justice to prevail." 45 Yet if extending territorial boundaries was not necessary to achieve greatness, one might be tempted to ask why Napoleon wanted to obtain Nice and Savoy and the Rhineland for France. I believe the answer lies in an observation made in 1860 to the French Ambassador to Austria on his departure from Paris. Napoleon remarked that if France were able to obtain her "natural" borders, for example the Alps, this would mean it could spend less on defence and devote more money to commercial developments as England did. He had observed that England's commercial superiority was a result of her isolation and therefore there was not as much need to spend money on defence. Every year France lost a large portion of her male population to conscription when they could be used productively at home to improve France's commercial situation. ${ }^{46}$ To our eyes perhaps a legitimate argument, but to the statesmen of the mid-nineteenth century Napoleon's motives would always be suspect. Although Nice and Savoy were annexed to France in 1860 by peaceful means, England and the rest of Europe were convinced that Napoleon would ultimately claim the Rhineland for France too, despite his protestations that he would never act against the will of the people in those lands.

Napoleon's comments were supported by his Minister, Persigny in the same year, and many years later by Ollivier in an article on Napoleon's foreign policy. Persigny said to the Conseil général de la Loire:

Dans l'état actuel des sciences militaires, un fleuve comme le Rhin n'est pas une frontière stratégique. Ce n'est donc pas pour un avantage illusoire que la France irait s'exposer à une nouvelle guerre européenne. 47

\footnotetext{
45 Discours at the opening of the legislative session. I February 1859. AN: 400AP 54, Archives Napoléon. ${ }^{46}$ Lord Augustus Loftus to Russell, 19 April 1860. PRO: FO519/198. Cowley Papers.

${ }^{47}$ Persigny to Conseil général de la Loire, 27 August 1860 . Recounted by Émile Ollivier, L'Empire libéral, Vol. 5, pp. 66-67.
} 
Ollivier also dismissed the idea of Napoleon wanting to extend France's frontiers as totally incompatible with his policy. He wrote:

L'Empereur, sous la pression de l'opinion publique et quoique cela lui fût personnellement indifférent, eût peut-être souhaitee, sans toucher aux provinces rhénanes, une rectification de frontières vers le Palatinat. Mais comme toute combinaison de ce genre dépendait du libre assentiment des populations et qu'il savait cet assentiment impossible, il n'a jamais rien sacrifié à cette convoitise mesquine . . .48

Although there is little evidence to support the claims of his opponents, England remained constantly alert for any signs of French aggrandisement.

As shown in the Introduction Napoleon did want to overturn the Treaties of 1815 , but not in an effort to make France once again Master of Europe. He saw instead a Europe united to improve social, industrial and commercial conditions for everyone, rather than divided over territorial squabbles and rivalries. Echard showed that it is only by accepting this philosophy of Napoleon's that his foreign policy can be understood. His contemporaries, however, preferred to classify his "ideas" as the dreams of a romantic because they seemed too esoteric or grandiose to be achieved. Prévost-Paradol saw them as the dreams of a "mediocre visionary", while Napoleon's unrelenting critic Zola said he had "more imagination and reverie than judgement. He tried to live the life dreamt of by the prisoner of Ham." 49 But their greatest criticism was that he did not ever outline a comprehensive foreign policy with clearly stated objectives, which left his opponents and his fellow sovereigns apprehensive about what he might be intending to do. Instead he preferred not to be bound by a fixed programme but to follow his uncle's philosophy of adjusting his system according to events and circumstances. His proposals for European congresses were rejected on similar grounds. He refused to propose a definite programme of issues to be resolved by the congress to avoid preconceived ideas about an outcome, but this led England and Austria particularly to be anxious about his intentions for Europe. And of course his ideas were threatening to the likes of an ambitious Bismarck.

\footnotetext{
${ }^{48}$ Émile Ollivier, "Napoleeon III: Son dessin international", p. 53.

${ }^{49}$ Alain Plessis, The Rise and Fall of the Second Empire , pp. 8-9.
} 
In reviewing his foreign policy in 1859 Napoleon said what he had consistently tried to do was to reassure Europe regarding France's intentions; return France to its rightful place as a Power in Europe; closely secure their alliance with England and confirm his relationship with other Continental Powers. Of these, he placed most emphasis on the alliance with England which he considered so useful to world peace. He believed that his desire for a secure alliance with England was reciprocated by the Queen and men of State in England, but though this was outwardly England's desire, he was not to know the very real fear that was maintained in England of an invasion by France. 50

There was also a fundamental difference between England's and Napoleon's views of how to maintain peace in Europe. While England was concerned only with preventing the growth of one strong Power, especially France, and maintaining what they termed a "balance of power", Napoleon saw equilibrium among the nations of Europe as being the basis of lasting peace. For him equilibrium meant a small number of equally strong nations, rather than a few strong nations and many smaller ones which could be easily oppressed by their more powerful neighbours. This was why he became so involved in the issue of the unification of Italy and supported the moves for unification of Germany. For England, however, memories and fears of the first Napoleon were not to be easily erased, nor were their concerns to be allayed over the unification of Italy and of Germany, from which they feared Napoleon would demand territorial concessions to increase France's power and pose a threat to England.

Unaware of these anxieties Napoleon was determined to achieve a strong alliance with England and this was the basis of his decision to become involved in the Crimea in 1854, in China in 1860 to protect Catholic Missionaries and England's opium trade, and, I am convinced, in Mexico in 1861. But England, particularly in the person of Lord Palmerston, was to remain suspicious of France and convinced that Napoleon III, like

\footnotetext{
${ }^{50}$ Discours de l'Empereur à l'ouverture de la Session Legislatif de 1859, le 7 février 1859. AN: 400AP 54, Archives Napoléon.
} 
his uncle, was bent on invading England, regardless of any evidence to the contrary. Although English politicians, with a notable exception in Richard Cobden, harboured these fears, there were those in England who did believe in Napoleon's desire for a firm alliance. Support was expressed in particular in The Times, after the death of Napoleon in 1873:

there is no doubt that against the half-smothered animosities of French Chauvinism nothing availed us so much as the Emperor's stout determination, not only not to be driven into hostilities, but to strengthen the bonds of amity with us at any price. ... the conclusion of the Commercial Treaty and the abolition of passports in favour of English travellers must be traced to his sole initiative. $5 !$

In his address of 1 March 1860 Napoleon asked the Corps législatif to change the laws which had posed insurmountable barriers to trade by keeping tariffs high and thereby excluding many foreign products from their markets. Other countries had reciprocated, making the selling of French goods difficult also, so Napoleon announced that to help overcome these problems he had instigated a commercial treaty with England which could only strengthen the alliance between the two nations. His belief in free trade is also illustrated in a conversation between the English writer, Nassau Senior, and a member of the Corps législatif who said that he did not believe the Emperor wanted war, for it would damage his commercial policy which was so important to him. At a dinner he had heard Napoleon explain that "protectionism is the sacrifice of the future to the present, and of the many to the few, and ... that free trade was the best preservative of peace." 52

Although the commercial treaty was successfully concluded, Lord Palmerston was to prove the greatest obstacle to the realisation of Napoleon's vision of a united Europe, a strong ailiance with England and a world free of protectionism. Richard Cobden, the eminent British Member of Parliament who spent eighteen months in France negotiating the commercial treaty, was fulsome in his praise of Napoleon, and convinced of his

\footnotetext{
${ }^{51}$ The Times, 10 January 1873.

52 Conversation between Nassau Senior and Kergolay, 8 September 1860 . Naussau William Senior. Conversations, Vol. 1, pp. 16-17.
} 
peaceable intentions towards England. In a speech to his constituents in June 1861

Cobden asked them how they could possibly believe the rumours that had been rife about an invasion of England by France when France had been prepared to subvert its commercial system totally to achieve this treaty with England. He said;

I ask you ... is there no presumptive evidence calculated to make you pause before you believe as probable or true what certain Admirals . . . say as to the French Government and the French meditating to attack or invade this country, when you find that Government engaged in this most difficult task, the subversion of their commercial system, by throwing open the markets of that country to the manufactures of England and opening the markets of England to the productions of France? I say, is there not something in this fact to make you pause before you believe on the mere ipse dixit of some not over-wise Admiral, who has never given one fact to prove what he says, that it is the design of the French Emperor to come and invade your shores without cause of quarrel or without grievance assigned? But I don't ask you to rely upon probability of things in this matter. I speak to you of facts facts which have come within my own knowledge - facts which I, perhaps better than any man in the world, have had the opportunity of knowing and investigating. ${ }^{53}$

He went on to provide facts and figures to show that France's navy was by no means superior in terms of the number of ships or men that they had, but that the French had used their budgets far more wisely than England and employed the new technology of iron-clad ships far more efficiently than they had. Consequently they had these new ships before England, which led to the rumours that they were now superior and intending to invade England. In fact France's navy was about half the size of England's at this time in the number of both men and vessels.

In 1861 and 1862 Cobden found many opportunities to expose the attitude of the English Government towards France. But he laid the blame for the paranoia about an invasion at the feet of Lord Palmerston, who had been a child in the Napoleonic era and had never been able to rid himself of this distrust of France, and of a Bonaparte in particular. Cobden could show that there was no shred of evidence to support Palmerston's claims, nor to justify his plan's to construct fortifications to withstand an attack from France. He believed that Palmerston's ploy was to distract the country from

\footnotetext{
${ }^{53}$ Cobden to his constituents in Rochdale, 26 June 1861. Bright and Rogers (eds), Speeches on Questions of Public Policy by Richard Cobden, M.P., (London, 1878),.pp. 425-434.
} 
the financial mismanagement of his government in foreign affairs, for why else would he continue to support an alliance with France and undertake overseas campaigns with her if he really believed France an enemy? ${ }^{54}$ But Palmerston found evidence in all quarters to start new rumours. In December 1861 he was convinced that Napoleon intended to make war in Europe in the summer of 1862 . This time not only Cobden, but also Cowley was certain there was no truth in the rumour. ${ }^{55}$ However, Palmerston's agitation kept suspicion of Napoleon constantly high.

Despite these setbacks, Napoleon showed even in 1866 and later, that he had not altered his views on how peace and prosperity could be maintained. In May 1866 he proposed to England that France, England and Russia meet to discuss the issues of Venetia, the Danish Duchies and the reform of Federal Germany. Once again England, in the person of Lord Clarendon, assumed that the idea would be to force the offending countries to take certain action. In this case, Prussia would either be prevented from annexing the Duchies, or alternatively allowed to do so, and Austria made to cede Venetia to Italy, he told Cowley, and "the British Government could not be a party to such transactions."56 After the rejection of this congress Napoleon expressed to Drouyn de Lhuys what he had hoped to achieve in the congress, showing there had been no intention of changing anything by force:

Nous aurions, en ce qui nous concerne, désiré, pour les Etats Secondaires de la Confédération une union plus intime, une organisation plus puissante, un rôle plus important; pour la Prusse plus d'homogenéité et de force dans le nord; pour l'Autriche le maintien de sa grande position en Allemagne. Nous aurions voulu en outre, que, moyennant une compensation équitable, l'Autriche put ceder la Vénétie à l'Italie; car si, de concert avec la Prusse et sans se préoccuper du traité de 1852, elle a fait au Danemark une guerre au nom de la nationalité allemande, il me paraissait juste qu'elle reconnut en Italy le même principe, en complêtant l'indépendance de la peninsule.

\footnotetext{
${ }^{54}$ Speeches by Richard Cobden to his constituants in Rochdale 26 June 1861, and 29 October 1862, and to the House of Commons, 1 August 1862. Ibid., pp. 440-441.

${ }^{55}$ Cowley to Russell, 7 January 1862. PRO: F.O. 519/229 Cowley Papers, (copies), and Cowley to Russell, 9 January 1862. PRO: PRO30/22/57, Russell Papers.

${ }^{56}$ Lord Clarendon reporting to Cowley a conversation with the French ambassador, 9 or 10 May 1866.

Colonel the Hon. F.A. Wellesley, (ed.), The Paris Embassy During the Second Empire (London, 1928), p. 303
} 
Telles sont les idées qui, dans l'intérêt du repos de l'Europe, nous aurions essayé de faire prévaloir. Aujourd'hui, il est à craindre que le sort des armes seul en décide. ${ }^{57}$

English statesmen could never see that his ideas were aimed at the peaceable solution of long term problems, which ultimately were resolved, for better or worse, by force of arms as Napoleon had feared.

These views, expressed to Drouyn de Lhuys, were to be given to his ambassadors, along with his current policy, which was to remain neutral. France's two interests, he said, were conserving the equilibrium in Europe and maintaining the work they had contributed to in Italy. If war did break out he had been assured by the courts involved that none of the issues affecting France would be resolved without their agreement. He concluded:

Restons donc dans une neutralité attentive et, forts de notre désintéressement, animés du désir sincère de voir les peuples de l'Europe oublier leurs querelles et s'unir dans un but de civilisation, de liberté et de progrès, demeurons confiants dans notre droit et calmes dans notre force.

Napoleon's policy, however, was not understood by the majority of his own countrymen either, and his Minister of the Interior, Lavalette, temporarily responsible for Foreign Affairs, revealed their uncertainties in an open letter to Napoleon in August 1866, written the day after he had a lengthy discussion with him. Public opinion, he said, fluctuated between hopes of territorial aggrandisement, fears of the expansion of Prussia, regrets at the powerlessness of Austria and doubts about the future of Italy. To end this state of uncertainty Lavalette suggested that the Emperor explain his policy and the country would be behind him. He then said, "Selon moi, il y a une politique aussi généreuse que vraie à soutenir et à exposer." He continued with a lengthy exposé, in his own words, of how he saw that policy.

The country must realise, he said, that Napoleon's policy had only ever redressed injustices and not satisfied ambitions, because there was no advantage in having weaker

\footnotetext{
57 Napoleon to Drouyn de Lhuys, 11 June 1866. AN: 400AP 42, Archives Napoléon.
} 
neighbours. Their neighbours were no longer necessarily rivals, and France's relations with England showed that the interests that brought them together were greater than the differences that divided them. The advantages that France might gain from a small increase in its territory, he said, could not compensate for the reproach that a liberal Europe would make against them. The independence of Italy had finally been achieved, not for the glory of France, but for Europe as a whole. Similarly, now that Prussia's role in the German Federation had changed, France and Prussia would be closer. The Rhine would no longer be the field of battle for rival ambitions, but the link between reconstituted nationalities. He foresaw a strong accord between Prussia, Italy and France which would become the instrument and the guarantee of the progress and civilisation of Europe, and he asked if this extension of France's influence was not preferable to gaining some small amount of territory. He could not foresee that Bismarck's ambitions were more base than Napoleon's as he concluded:

À d'autres époques, la puissance nationale s'est constituée par la guerre. C'est par la paix et l'alliance avec les nationalités que nous la maintiendrons aujourd'hui. La paix qui nous permettra de répandre partout nos principes et nos produits ne vaut-elle pas mieux pour la France que la guerre qui nous donnerait, à titre de peuples conquis, ceux qui veulent être des peuples alliés. ${ }^{58}$

Apparently in response to Lavalette's prompting, Napoleon drafted a letter to his Ministers in the European capitals exposing his view of the future of Europe in the light of the recent Austro-Prussian conflict, and the advantages of the movement towards larger national states. This letter was published as being written by Lavalette in Moniteur on 17 September 1866. Europe knew, he wrote, that the greatness of a nation no longer depended on the weakness of its neighbours and that true equilibrium could only exist when the wishes of all the European nations were satisfied. He added:

le Gouvernement impérial a depuis longtemps appliqué ses principes en matière d'extension de territoire. Il comprend, il a compris les annexions commandées par une nécessité absolue, réunissant à la patrie des populations ayant les mêmes mœurs, le même esprit national que nous et il a demandé au libre consentement de la Savoie et du comté de Nice le rétablissement de nos frontières naturelles. La France ne peut désirer que les agrandissements territoriaux qui n'altéreraient pas sa puissante cohésion;

\footnotetext{
${ }^{58}$ Lavalette to Napoleon, 14 August 1866. AN: ABXIX 174.
} 
mais elle doit toujours travailler à son agrandissement moral ou politique, en faisant servir son influence aux grands intérêts de la civilisation.

Son rôle est de cimenter l'accord entre toutes les puissances qui veulent à la fois maintenir le principe d'autorité et favoriser le progrès. Cette alliance enlèvera à la révolution le prestige du patronage dont elle prétend couvrir la cause de la liberté des peuples et conservera aux grands États éclairés la sage direction du mouvement démocratique qui se manifeste partout en Europe. 59

Napoleon's agents were advised to present these ideas in their discussions with the governments to which they were accredited. They were, however, neither understood nor supported by governments who only saw him as seeking to increase his own power in Europe, and as Albert Guérard said, while to him "the doctrine of nationalities ... was the very condition of permanent peace ... it was bound to disturb the status quo." He commented further that Napoleon's ideals should not be regarded as too Utopian because they were "essentially the same as Woodrow Wilson's principle of selfdetermination." 60

Echard has shown that historians have failed to understand Napoleon's foreign policy because they assumed that his conference policy was really intended to achieve territorial growth for France. In addition some, such as Albert Pingaud, decided that Napoleon's efforts to conclude alliances with Britain, Russia, Austria and Prussia at varying times during his reign meant he could not decide with whom to have an alliance. ${ }^{61}$ Others then concluded that because he approached so many different courts he did not in fact ever have a policy. Echard's study, however, reveals that Napoleon believed the only way his congress idea could be successful was if there were general understandings between some of the major powers before such a congress took place, and this was why he was prepared to approach different courts regardless of the relationships between individual Powers. ${ }^{62}$

\footnotetext{
${ }^{59}$ Notes by Napoleon on foreign relations, no date. AN: 400AP 54, Archives Napoléon. Reproduced as a letter of instruction from Lavalette to the Emperor's diplomatic agents and printed in Moniteur, 17 September 1866. 60 Albert Guérard, "Cæsarian Democracy", pp. 57-58.

${ }^{61}$ Albert Pingaud, "La Politique Extérieure du Second Empire”, Revue Historique, Vol. 156, November/December 1927, pp. 41-68.

${ }^{62}$ William Echard, Napoleon III and the Concert of Europe, pp. 183-184.
} 
Napoleon's foreign policy was neither indeterminate nor vacillating, and his exposé of his policy in his addresses, and more particularly in his letters and notes in 1866 , confirm that he in fact remained faithful to the ideas expressed in his youth. He was just far too advanced in his view of the world for his more conservative contemporaries. If his views regarding Europe were to be subject to suspicion by other nations, the idea of extending his policy beyond Europe could only be considered by them as self seeking. Yet Mazade, whose incisive articles show his merit as a keen and unbiased observer, said his fifteen years of watching the progress made in France convinced him of Napoleon's selfless motivation. ${ }^{63}$ His desire to bring stability and development to nations consumed by anarchy was often expressed in his addresses to the chambers and supported by the observations of Ministers such as Rouher and Lavalette. Pierre de la Gorce commented that Napoleon's first concern was always for civilisation and humanity, which, I believe, was the basis of his reign. La Gorce said:

Bien que très zélé pour servir ses sujets, il ne dit pas: France d'abord, mais d'abord la civilisation et l'humanité. Cette tendance, à la fois magnifique et dangereuse, inspira toutes ses entreprises: en lui, une conception tout internationale de ce qui était, de ce qu'il croyait le bien. ${ }^{64}$

He supported Lavalette's views by showing that after all the conflicts Napoleon was involved in he never sought any compensation for France but was concerned only for the freedom or betterment of other peoples.

How then could his policy be seen to be any different in Mexico, and where does Mexico fit in that policy? Napoleon's overwhelming concern was for peace and unity within Europe, but his ideal, seen in his interpretation of the policy of Napoleon I, was to see that peace and unity encompass the whole world. As Rouher said, he was a man who had the courage to take a risk to open up new avenues for prosperity for his country and to recognise that European equilibrium now embraced the entire world. It has been seen that Napoleon believed free trade was the basis of peace between nations, and that protectionism was the sacrifice of the many to the few, and this was why Rouher called

\footnotetext{
63 Mazade to Eugenie, 17 July 1865. AN: ABXIX 174.

${ }^{64}$ Pierre de la Gorce, Napoléon III et Sa Politique, pp. 37-39.
} 
the Mexican venture "la grande pensée de la règne”. Napoleon's aim in Mexico therefore, was just as he had stated it to Forey, to maintain for Europe, not just for France, access to the markets of the Americas which Europe had every reason to suspect the United States wished to monopolise for themselves. Just as trade barriers in Europe caused problems to peace and commerce, the total control of American markets by the United States could affect the commercial development of Europe and possibly pose a threat of war. General du Barail said that Napoleon could see that if a huge republic developed on the other side of the Atlantic, free from the rivalries that gripped Europe, it could put all its energies into an economic struggle in which Europe would be the loser. Writing in 1898 du Barail could say:

Aujourd'hui, cette lutte a commencé, et beaucoup de bons esprits sont effrayés des échecs que nous avons déjà subis. L'Europe, morcelée et hérisée de baïonnettes, se trouve dans un état d'infériorité fatal en face de l'Amérique. 65

Twenty five years after Napoleon's death his endeavours began, at last, to seem less chimerical than they had in his lifetime.

If, however, Napoleon's interest was mainly in seeing the unity and prosperity of Europe, and issues in Europe were consuming most of his time and energy, why did he decide to become involved in Mexico? Could it not be that the problems in Mexico presented an opportunity whereby he could fulfil another ambition which was consistent with his view of the world? He could firstly help to bring peace and prosperity to a country ruined by anarchy and in danger of being absorbed by the United States, and secondly he could pursue his aim of reducing protectionism in world trade. These intentions were far beyond the narrow idea of creating a Latin-Catholic bloc or of extending monarchies throughout republican America, of which he has been accused. As William Smith said, to accept this is to misunderstand the mission that Napoleon believed France had:

To him the vision was one of a world which would be based upon national groupings, so balanced as not to be competitive, held together by a common

${ }^{65}$ Général du Barail, Mes Souvenirs, Vol. 2, pp. 290-291. 
desire to promote trade, prosperity and international peace. His war would be one of words his battlefields the green baize of the tables, where met the congresses of the Powers. Whole armies of words would march at his command and his opponents could not but be overcome by logic and common sense. They would, he always felt, understand his dream It was a reasonable assumption in that most of his contemporaries had in their youth waded, as he had, through the flood waters of romanticism and had not emerged bone dry. 66

But if they had been consumed by the same ideas in their youth, many of his contemporaries, especially the English ones, had relinquished their youthful ideals, perhaps because they had become more concerned with remaining in power. Richard Cobden made a remark to this effect about Lord Russell when he told the House of Commons that foreign governments felt that the Foreign Office had no power, because the power rested in the House, "and foreign Governments more than suspect that your Foreign Minister is often playing a game with them from time to time merely to suit his policy and his prospects in this House." 67 It was this that had prevented Russell from being frank with parliament about Napoleon's ideas for Mexico in 1861, after telling Napoleon's ambassador that he agreed with them. This resulted in confusing messages being given to Napoleon which had considerable impact on the course of the intervention.

If Mexico was seen as an opportunity to achieve world unity, it might be asked why Napoleon was ready to abandon the project in 1866 instead of pursuing it to its conclusion. But once again he was demonstrating the flexibility of his policy and showing that he was not obsessed with his vision and determined to fulfil it regardless of the cost. He may have been disappointed, but that is not to say he would not look for another opportunity in the future; his unflagging belief in the benefits of a European Congress and his repeated attempts to convene one demonstrate that he was not so easily disillusioned. It also reminds us of his one criticism of his uncle, that he fell because he tried to accomplish in ten years the work of several centuries. Napoleon III had much

\footnotetext{
66 W.H.C. Smith, Napoleon III, pp. 169-170.

${ }^{67}$ Richard Cobden in House of Commons debate, 5 July 1864. Quoted by Kenneth Bourne, The Foreign Policy of Victorian England, pp. 378-379.
} 
more patience than that and was prepared wait and take advantage of opportunities as they arose. All that remains is to determine whether Napoleon III should be condemned for the failure of his expedition or given due credit for a grand vision of the world. 


\section{Tomelugton}

Historic sense forbids us to judge results by motive, or real consequences by the ideals and intentions of the actor who produced them.

\section{Viscount Morley 1}

There may indeed be merit in these words, for the truth is we can never know in retrospect whether, in other circumstances, the ideals of "the actor" may have been fulfilled. There is no reason why the intentions of Napoleon III should be considered any differently in this respect when projects such as the Mexican venture and his attempts to achieve European unity ended in failure. But when it can be seen that to a certain extent Napoleon's vision has been achieved, albeit more than a century after his death, perhaps his intentions require greater evaluation. The majority of European nations today have finally accepted that it is in their interests to co-operate as a united body, and a European Parliament has been convened to consider matters that concern Europe as a whole. And although there may still be difficulties experienced between countries as far as tariff barriers are concerned, it has been recognised fairly generally that free trade provides a sound foundation for peace.

Had the Mexican venture succeeded, it would no doubt have been hailed by all as "la grande pensée de,la règne", but failure should not prevent recognition of the value of an idea. Napoleon was reminded, some time after Mexico, of a saying of La Rochefoucauld:

As most people consider only the appearance of things, their judgements are based solely on results, so that a design of a plan seems to them well formed or well carried through only when the result is good. ${ }^{2}$

\footnotetext{
${ }^{1}$ Quoted in his frontispiece by Harold Nicolson, The Congress of Vienna; A Study in Allied Unity 1812.1822 (London, 1946).

${ }^{2}$ Comte Fleury (ed.), Memoirs, Vol. 2, pp.105-106.
} 
There was a vast difference between Napoleon's intentions to develop Mexico and save it from the devastating effects of anarchy, and those of various American diplomats to annex regions of Mexico, particularly those richest in natural resources, as payment for their debts. In such a comparison Napoleon must be recognised as having selfless and humanitarian motives. Had the government of Maximilian been able to sustain itself and quell the resistance of Juarez who received much unofficial, and some official, support from the United States, Napoleon would have been praised for bringing stability and prosperity to the nation. If European influence had been maintained in Central America the United States almost certainly would have been unable to introduce a policy of protectionism, which began to have an effect on Europe in the decades before the First World War.

There can be no doubt, when in the late twentieth century we see some of Napoleon's ideas have come to fruition, that he was a visionary, but unfortunately out of step with his contemporary statesmen. The main difference between Napoleon III and them was that he was not a traditionalist, and Albert Guérard said:

his distinction among rulers is that he anticipated and tried to shape the future; his genuine greatness is that, in many important fields he proved a true prophet, and that the solutions for which he worked are still our hope today. .. . But if failure must be admitted as an indictment, it need not be accepted as an all-embracing and conclusive condemnation. A man may fail, as Saint-Louis, Napoleon I, Lafayette, and Woodrow Wilson did fail, without being branded as a knave or a fool. ${ }^{3}$

But because his contemporaries could not accept what Napoleon was trying to achieve, and could not rid themselves of their conviction that he was looking for compensation for France in Europe and the New World, he was branded by many at least as a "knave", if not also a "fool".

The idea of having a flexible foreign policy was totally incomprehensible to other foreign leaders and as a result they saw Napoleon as indecisive and vacillatory and therefore dangerous, because he was unpredictable. Cowley was at times one of his

\footnotetext{
${ }^{3}$ Albert Guérard, "Cæsarian Democracy", Napoleon III: Buffoon, Modern Dictator or Sphinx? Edited by Samuel M. Osgood (Boston, 1963), p. 65.
} 
greatest critics, and early in 1862 he wrote to Russell saying how indecisive and indolent he thought the Emperor was, yet he unwittingly showed that Napoleon had proven he was not a threat to Europe. He wrote to Russell at the time Palmerston thought Napoleon was considering war in Europe, commenting on the idea some had that Napoleon had assumed the throne with fixed ideas of the subjugation of Europe.

He has certain ideas and desires floating in his mind, which turn up as circumstances seem favorable, but a man of less decision of character, of more indolent disposition, or more inclined to wait upon events instead of creating them, I never came across. Her Majesty's Government will recollect the difficulty they experienced in first inducing him to send a few thousand men to Gallipoli. Would this have been so had he meditated the downfall of Russia? All must remember the uncertainty, hesitation and irresolution which preceded the Italian campaign, and which were alone put an end to by the insanity of Austria in declaring war on Sardinia. Would this have been so, had the destruction of Austria been part of a fixed plan, and would not a pretext for attacking Germany have been found before this, were Germany doomed in the Imperial mind? ${ }^{4}$

Despite all the examples that showed Napoleon was not looking for the aggrandisement of France, or the subjugation of Europe, suspicion remained high. Ollivier said that this unsupported suspicion was "one of the fatal consequences of the imperial restoration" and the English and European cabinets were unable to believe Napoleon III did not have the same ambitions as his uncle. 5

Perhaps much of the reason his intentions were not understood or accepted was because he expected that they would be, without his having to justify or explain himself. When he wrote Des Idées napoléoniennes he concluded his description of the system Napoleon I had intended to introduce by saying: "Il n'est plus besoin maintenant de refaire le systême de l'Empereur, il se refera de lui-même; souverains et peuples, tous aideront à le rétablir, parce que chacun y verra une garantie d'ordre, de paix et de prospérité" 6 Perhaps he expected the companions of his youth would retain the ideals they had all shared at that time. But the truth was that lack of understanding fostered rumour, conjecture and suspicion of Napoleon's intentions. His Minister, Lavalette, had

\footnotetext{
${ }^{4}$ Cowley to Russell, 9 January 1862. PRO: PRO 30/22/57, Russell Papers.

5Émile Ollivier, "Napoléon III: Son dessin international", p. 57.

${ }^{6}$ Napoleon III, "Des Idées napoléoniennes", p. 171.
} 
pointed out the problems of not explaining his policy, and had suggested the Emperor publish a summary of his foreign policy so the nation would be persuaded to support him. This they could not fail to do once they realised the Emperor's admirable intent. However, Napoleon's tendency to reflect and keep his own counsel, as described by d'Ambès and Fleury above, in Chapter 8 , led all but those who were very close to him to think he was shallow and incapable of informed action. His friend in exile, Count de la Chapelle, said of him,

He was a great philosopher and a great thinker, who liked to meditate in silence on the ideas which gushed forth from his powerful brain, so as to cause them to see the light when he thought that the proper hour was come; but, until that time arrived, he wrapped himself in a cloak of taciturnity, and at the least questioning retired within himself. ${ }^{7}$

Chapelle also remarked that all Napoleon's actions, both as Emperor and in exile, always had as their motive "the happiness and greatness of France."

Recriminations against Napoleon, however, were strong among the French, and immediately after his death the French press poured forth much bitter criticism of the man who had led them for over twenty years, many conveniently remembering only the failures of the later years and ignoring the achievements of the early years of the reign. Le Temps was almost vitriolic, claiming Napoleon alone was responsible for the ruin of the later years and the troubles that had continued after the defeat of 1870 . He had led France into the abyss thereby demonstrating that Bonapartism had only ever led to the invasion and dismemberment of France. The author added:

Insensible à sa chute et aux malheurs de la France, affligé peut-être de la voir se relever sans lui, Napoléon III est mort sans doute plein de chimères et d'espérances. Il ne faut pas douter que ces chimères ne tâchent de lui survivre. Mais cela n'importe pas. Ce qui importe, c'est que la France soit à jamais guérie de la folie bonapartiste, et elle a, certes, payé sa guérison assez cher pour se garder de toute rechute. ${ }^{8}$

There were other opinions, however, and in newspapers such as La Presse, Moniteur Universel, La France, and Paris-Journal a deliberate attempt was made to

\footnotetext{
${ }^{7}$ Count de la Chapelle, Posthumous Works, pp.5-6.

${ }^{8}$ Le Temps, 10 January 1873.
} 
remind the French people that the Empire had not experienced only disasters. La France commented:

ni les fautes extérieures et intérieures de l'Empire . . . ni les faiblesses des derniers jours contre lesquelles l'opinion publique s'est déchaînée ne doivent nous faire oublier que le règne de Napoléon III a été marqué par un développement de prospérité matérielle dont nous ressentons encore les effets; que la France, après les guerres de Crimée et d'Italie, avait recouvré sa prépondérance en Europe. ${ }^{9}$

In similar vein Paris-Journal wrote:

Pour nous, le règne de l'empereur Napoléon III est un des plus féconds en grands résultats que l'histoire de notre pays aura à enregister; il comptera, malgré les malheurs de la fin, parmi les plus prospères.

L'ordre maintenu à l'intérieur, le progrès dans les institutions constitutionnelles, le développement de la richesse nationale sous l'influence d'une législation économique libérale, constituent un ensemble qui a sa grandeur. ${ }^{10}$

And the Moniteur Universel criticised the radicals and their press who focused their condemnation of Napoleon on the coup d'État, forgetting their own actions in 1848 and 1870 which were much more revolutionary, and in some cases violent. It then added:

L'empereur n'eut pas toutes les qualités d'un souverain, mais il en eut plusieurs et il serait absurde de supposer qu'il dut uniquement au hasard les succès qui marquèrent la première partie de son règne. Peut-être voulait-il faire trop de choses, mais il en fit inconstestablement beaucoup d'utiles. $\grave{A}$ l'intérieur. il favorisa avec suite et intelligence les progrès de l'agriculture, de l'industrie et du commerce; à l'extérieur, si sa politique ne fut pas toujours conforme à nos traditions, elle ne manqua pas d'éclat. ${ }^{11}$

Although there were many comments in the French press relating to the death of Napoleon, and some commentary on his reign, they in fact occupied very little space in the various papers. In contrast the English press, particularly The Times, devoted pages to a résumé of his reign, and accounts of his illness and the details of the operations that attempted to disintegrate the bladder stones that finally caused his death. Although critical of some aspects of his reign and of his ability to startle his neighbours with his

\footnotetext{
${ }^{9}$ La France, reported in La Presse, 12 january 1873.

10 Paris-Journal, ibid.

$11_{\text {Moniteur Universel, ibid. }}$
} 
seemingly erratic foreign policy, The Times was fulsome in its praise of his person, and said in part:

Napoleon III had the qualities which win personal affection, respect and admiration. He had genuine love and friendship; he was loyal to his friends, true to all who worked with him, had his full share of personal courage, and was most grateful to all who had ever done him even a small service. It is not too much to say that he had the kindest recollection of everybody who had shown him even a passing civility in the course of his varied fortunes.

He had a true love for his country even though he could not but identify her fortunes with his own. All his schemes for her domestic improvement, for the emancipation of her trade and industry, and the extension of commerce by new and unheard of channels were magnificent. ${ }^{12}$

It also passed comment on the reaction of the French press, whom, it said, seemed to want to put the blame for all France's problems on the shoulders of one man, and to condemn him for his failures while conveniently forgetting his successes. They seemed to forget that France was at the present time in a state of political turmoil, which was perhaps more worrying than some of the years under Napoleon:

Not one of the many factions into which France has divided herself is at all in a condition to boast either of what it has done since the downfall of the Emperor, of its present position, or of its prospects. A third year has come upon this sea of troubles, and finds them all engaged in a vain attempt to agree upon the mere outlines of the Constitution that is to be. ${ }^{13}$

Napoleon was dead, and he had left behind him a number of failures from the last years of his reign, not the least of them being the disastrous defeat of the Empire at the hands of Bismarck in 1870, but also the failure of the Mexican venture, which some believed contributed to the later defeat. Although this itself might require a lengthy study, Marshal Randon provided a report which showed that the Mexican campaign had not by any means left the supplies of military equipment seriously depleted or left the army in a position that it could not meet any sudden military necessity. When recounting this episode Count de la Chapelle agreed Randon might have been correct in respect of military equipment, but he commented that "he was deceiving himself with fatal

\footnotetext{
${ }^{12}$ Quoted by Count de la Chapelle, Posthumous Works, pp. 267-268.

${ }^{13}$ The Times, 13 January 1873.
} 
delusions" when he claimed that "the army was ready to undertake a great war."14 This debate, however, belongs more appropriately perhaps to a study of the war of 1870 , and must include Napoleon's battles with his Ministers regarding the reorganisation of the army.

Napoleon himself was prepared to comment on why he believed there were so many setbacks during the last years of his reign. He said to Count Fleury one day:

I have been represented as false and without any fixed principles, promising one thing to-day and doing another thing to-morrow; in a word, it has been held that I was actuated only by vulgar ambition. . . . From the very start, in 1852 , the aim of the Tuileries was to increase the prestige of France and secure a better general situation throughout Europe. So long as my authority was respected and strong, the country remained prosperous and calm, and external affairs gave no cause for alarm. During the existence of the moderate and prudent system, which our critics have called 'the personal government of the Emperor', France enjoyed peace and security. Disaster came only when the so-called parliamentary system was adopted and when responsibility centred in the ministers. Yet public censure has passed them over. ...15

He naturally encountered the problems of most visionaries who try to have their ideas implemented by others who do not see things in the same way, and who therefore perhaps unwittingly sabotage their plans. Charles de Mazade could see this, and Napoleon learned, as many do, that there can be drawbacks to democratic government. Although democracy was always his aim, it did not sit as comfortably with him as he would have liked.

But it was his own decision to make his government more liberal, although James McMillan remarked that the reforms "can still be seen as a response to one of the Empire's more serious weaknesses; namely, its failure to win over completely the old Orleanist elites, upon whose goodwill the regime depended so much for its smooth functioning." He, along with others, holds that Morny and Walewski persuaded Napoleon to introduce reforms before he was forced to do so. ${ }^{16}$ Ollivier, however, maintained he was not pressured to do so, but that he had achieved, essentially, many of

\footnotetext{
${ }^{14}$ Count de la Chapelle, Posthumous Works, pp. $116 \mathrm{ff}$.

${ }^{15}$ Count Fleury (ed.), Memoirs, Vol. 2, pp. 139-140.

16 James McMillan, Napoleon III, p. 65.
} 
the things he had set out to do which required personal leadership, and, like Moses he was weary from carrying the load alone. Therefore he had no reason not be liberal or to refuse the nation a more active part in its affairs. It was at this time, when discussion of the address and the right to propose amendments was given to the Corps législatif, that Ollivier decided to help the Emperor establish a government of liberty. He commented on Napoleon's decision:

Elle n'était pas l'expédient suprême d'un pouvoir agonisant, essayant de se sauver, par la lâcheté des concessions, d'une chute que ces concessions accélèrent; elle était opérée en pleine puissance par un pouvoir formidable établi sur le roc, dont personne ne pouvait prévoir l'ébranlement. ${ }^{17}$

Nor could Napoleon have foreseen how difficult it was to be for him to control a "liberal empire".

It has been remarked that unfortunately the freedom of expression granted to the opposition just happened to coincide with the military defeats of the later years of the Empire, and that the denunciation of the Mexican expedition by Favre was echoed in parts of the press that were always hostile to the Empire. Some pamphlets at the time gave to the expedition and to its consequences simplistic explanations which were really a reflection of political faction fighting. ${ }^{18}$ The freedom of the press granted in these later years led to an influx of new papers in the hands of long repressed opponents of the Empire, who unleashed their vitriol against the government, attacking the entire reign and in particular the "criminal" coup d'État. 19 The result was an inability to see anything but failure attached to the whole period of the Second Empire, as has been seen in the reactions of some of the French press after Napoleon's death.

But despite his defeat and failures, it is impossible to deny the personal qualities he had of kindness and gentleness and a refusal to blame others who were equally or more responsible for the final disaster. As a person the English admired him greatly, and more

\footnotetext{
17Émile Ollivier, L'Empire libéral, Vol. 5, pp. 89-90.

${ }^{18}$ Pierre Guiral, Émile Témime, "L'Historiographie du Second Empire", Revue d'Histoire Moderne et Contemporaine, Vol. 21, January-March 1974, p. 12.

${ }^{19}$ Alain Plessis, The Rise and Fall of the Second Empire, pp. 164ff.
} 
than twenty thousand people visited Chislehurst, the place of his death, in the days before his funeral. A journalist with The Times commented that Napoleon had every reason to feel bitter after his defeat, and his illness was so bad he had every reason to be deeply depressed, but

he not only preserved his apparent serenity, but displayed invariably that dignified courtesy which denotes a man too stable to be easily shaken. ... beset by a mortal malady which would have made most men irritable and captious, the Emperor has shown himself invariably calm and strong. Nothing perhaps, is so admirable in the life of this remarkable man as the silence he has consistently preserved with regard to those whose ill-advised counsels, incapacity and self-interested falsehoods contributed so largely to his ruin. 20

A French journalist with Liberté also wrote of Napoleon's valuable qualities, concluding with a well-known epithet:

L'empereur possède au plus haut degré deux qualités souveraines: la bonté et la douceur. S'il n'en eût pas été essentiellement doué, nous eussions eu, le lendemain du 2 décembre 1851, le despotisme et le despote, tandis que nous avons eu la tyrannie sans avoir le tyran. . . .

Nul n'a des intentions meilleures. Nul n'a des tendances plus justes. Nul n'a plus profondément le sentiment qui correspond aux inspirations des masses, aussi existe-t-il entre elles et lui un courant sympathique qui a résisté à des épreuves sous lesquelles eût succombé tout autre prince régnant.

$\mathrm{Au}$ temps où l'on décernent aux souverains des surnoms, on l'eût surnommé Napoléon le Bien-intentionné. ${ }^{21}$

Should these opinions of Napoleon be dismissed in the light of the words of Viscount Morley quoted above? The fact is that they cannot be, for although he failed to achieve his plans in the 1860 s we are confronted today with the realisation of some of them by others who have seen the necessity of following his pioneering role. That he was genuine in his intentions is difficult to doubt, for foremost among Napoleon's characteristics were those of sincerity and concern for others. In all his correspondence that I have read, both official and personal, including to family, friends and others entirely unknown to him, it is that quality of sincerity that is striking. He may be accused

\footnotetext{
${ }^{20}$ The Times, 10 January 1873.

${ }^{21}$ Émile de Girardin, Extract from a comment in Liberté, reproduced in La Presse, 12 January 1873. Emphasis given.
} 
of making errors of judgement relating to the situation in Mexico and to his

representatives, but his stated motives cannot be considered anything but genuine. When discussing a book about to be published on Napoleon III by a noted historian, his widow Eugenie said to her personal friend and secretary, Augustin Filon, "Tell him that if he does not admit that sincerity was the Emperor's greatest virtue he will have failed to understand him." Filon added, "And it must be clearly understood that sincerity was in the eyes of the Empress, the first of all the virtues, without which the others could not exist." 22

My research has revealed that Napoleon III has been considered in a very narrow way by historians. His correspondence with Maximilian, Forey and Bazaine, however, has shown that he was not blindly obsessed with achieving a goal, but was sensitive to the difficulties that arose and was prepared to abandon or modify his plans if it were warranted. This research has found also that Napoleon was neither indolent nor inept. His instructions were clear and precise, and he expressed anger and disappointment with his envoys when faced with their independent actions, which he immediately tried to redress. The way in which this campaign at least, was conducted, refutes also the claims that Napoleon failed to follow through the implementation of his policy after issuing instructions. One might then ask why the intervention in Mexico has been seen previously in such a negative light, but perhaps, as with many other aspects of Napoleon's reign, it has been clouded by "the appearance of things". William Smith recognised that one of the tragedies of the Empire was that the brilliant court life that was developed to help improve the prestige of France with other older European monarchies, gave a false impression of both Napoleon and Eugenie. ${ }^{23}$ It served to give those who saw only this aspect of Napoleon the impression that he was frivolous and inept. In a similar way, consideration of the Mexican venture has been clouded, firstly by too much attention to anecdotal evidence which said there were secret instructions and also that Napoleon wished to establish a Latin Catholic bloc in the Americas, and secondly by the

\footnotetext{
22 Augustin Filon, Recollections of the Empress Eugénie (London, 1920), p.26.

${ }^{23}$ William H. C. Smith, Napoleon III: The Pursuit of Prestige, p. 38
} 
unquestioning following of the ideas of early historians of the venture, such as Corti. Corti's conclusions about Napoleon's intentions have been shown to be wrong and he has been seen to have misinterpreted some of the evidence he did have. Perhaps this indicates a need to re-examine the way in which other aspects of Napoleon III's reign have been regarded.

Because he was misunderstood and before his time, it was almost inevitable that it should be a more traditional and ambitious politician who ensured that Napoleon's view of the world was unfulfilled for a hundred years. It was instead "Bismarck who, carried forward by romantic enthusiasm and the unmatched discipline of a nation at the height of its powers whom he was able to galvanise into action, reached his deliberately restricted objectives and so clothed the tattered Europe of Napoleon MI in his own kind of tunic." 24 It was left to others who were also far-sighted, decades after his death and after two devastating world wars, to begin the slow process of fulfilling Napoleon's vision, at least in part. Napoleon III was not so unrealistic after all, as one hundred and twenty five years after his death the following appeared in the press:

Poland's former president, Lech Walesa, told the Cambridge Union that his ambition was to be the first president of a united Europe. 25

\footnotetext{
${ }^{24}$ Emile Lousse, "The True Place of Napoleon III in the History of Europe", Napoleon III and Europe. Edited by Jacques de Launay (Brussels, 1965), p. 147.

${ }^{25}$ Reported in The Advertiser, Adelaide, South Australia, 20 May 1996.
} 


\section{稆ibliography}

\section{ARCHIVAL SOURCES}

\section{London}

\section{Public Record Office}

Foreign Office Records to 1878

\section{General Correspondence}

France: FO 27/1377 - 1382, 1397 - 1400, 1412, 1419, 1431, 1482 - 1483, 1497 - 1498. Mexico: FO 50/327 - 328, 334, 353 - 354, 363, 364, 365. Spain: FO 72/934, 940 $-941,1002,1009-1012,1022,1028-1029$.

Supplement to General Correspondence

Mexico: FO 97/278 - 279. Spain: FO 97/397

Embassy Archives

France: FO 146/1009 - 1010, 1014. Spain: FO 185/380 - 381, 385 - 387, 392. Mexico: FO 204/153 - 154, 156, 159 - 160, 163.

Private Collections

Cowley Papers: FO 519/196 - 200, 207, 229, 268, 272, 300 - 301.

Russell Papers: PRO 30/22/29, 41 - 42, 56 - 57, 59, 62, 70 - 71, 74 - 76, 86, 95, 105, 115

Bloomfield Papers: FO 356/32..

\section{$\underline{\text { Paris }}$}

\section{Archives du Ministère des Affaires Étrangères}

Correspondance Politique

Angleterre: Vols 711, 719 - 721. Espagne: Vols 852, 859. Mexique: Vols 54 - 55, 5859.

\section{Papiers d'Agents - Archives Privées}

PA-AP 009 Barrot, Vols 15 - 17. PA-AP 242 Gramont, Vol. 3. PA-AP 233

Thouvenel, Vols 3,8,10,17.

Memoirs et Documents

Angleterre, Vol. 127. Mexique, Vol. 10. 
Service Historique de l'Armée de Terre (Chateau de Vincennes)

Archives du Ministère de la Guerre

Expédition du Mexique (1862-1867)

$G^{7} 1$ - 3 Correspondence du général en chef avec le Ministre (1862-1867)

G7 99 État-Major général : correspondance avec le Ministre, instructions de l'Empereur, correspondance générale (1862-1867)

Manuscripts

MR 851 Joumal de la Campagne du Mexique de la Hayrie

Archives Nationales

Archives Privées

107AP 14 Archives Gallifet; 223AP 16 Fonds Berryer; 249AP 5 Archives Randon; 320AP 2 Papiers Bazaine; 400AP 41 - 44, 52, 54, 61 - 63, 68 Archives Napoléon.

Dossiers du Cabinet de Napoléon III (papiers trouvés aux Tuileries en septembre 1870)

ABXIX 171 - 172 Documents relatifs à la guerre du Mexique. ABXIX 170, 173 - 175 Documents relatifs à tous les événements du règne de Napoléon III.

Fonds de la Marine

Campagnes

$\mathrm{BB}^{4}$ 799, 807, 810, 812 Expédition du Mexique 1861-1865. BB ${ }^{4}$ 1810, 1812, 1813, $1814,1817 \mathrm{bis}$ Papiers de l'Amiral Jurien de la Gravière

\section{PRINTED SOURCES}

Archives Diplomatiques : Recueil de Diplomatie et d'Histoire, 1862-1867 Kraus Reprint, (Paris, 1969).

British Documents on Foreign Affairs: Reports and Papers from the Foreign Office Confidential Print. Part 1, Series F. Europe 1848-1914: Vol. 9 France 1847-1878, Vol. 26 Spain 1846-1896. Edited by Kenneth Bourne and D. Cameron Watts

British and Foreign State Papers (Blue Books), Vols. 51-54, 1860-1864.

Exposé de la Situation de l'Empire présenté au Senat et au Corps Legislatif January 1863 (Vol. 1); November 1863 (Vol.2); (Paris, 1863); January 1866 (Vol.4), (Paris, 1866).

The Papers of Queen Victoria on Foreign Affairs. Part 5, France and Belgium, 18481900. Edited by Kenneth Bourne (Bethesda MD, 1990).

Parliamentary Debates, Third Series, Vols. 161-162, 165-168.

Parliamentary Papers, Parts 1-3 Correspondence relating to Affairs in Mexico, Presented to both Houses of Parliament by command of Her Majesty 1862 (London, 1862). 
Parliamentary Papers, Correspondence respecting the Congress Proposed to be held at Paris. Presented to both Houses of Parliament by Command of Her Majesty 1864.

\section{SECONDARY SOURCES}

Agulhon, Maurice The Republican Experiment 1848-1852. Translated by Janet Lloyd (Cambridge, 1989). Originally published in French as: 1848 ou l'Apprentissage de la République 1848-1852 (Paris, 1973).

d'Ambes, Baron Intimate Memoirs of Napoleon III: Personal Reminiscences of the Man and the Emperor, 2 Vols. edited and translated by A.R. Allinson (London, n.d.).

du Barail, Général Mes Souvenirs, 1851-1864, 2 Vols. (Paris, 1898).

Barker, Nancy Nichols Distaff Diplomacy. The Empress Eugénie and the Foreign Policy of the Second Empire (Austin, 1967).

Bismarck, Otto Prince von Bismarck the Man and the Statesman being the Reflections and Reminiscences of Otto Prince von Bismarck. Translated from the German under the supervision of A.J. Butler (London, 1898).

Black, Shirley Napoleon III and the French Intervention in Mexico: A Quest for Silver. Ph.D Dissertation, University of Oklahoma, 1974.

Blanchard, Marcel "Napoleon III: Aims, Achievements and Failures", Napoleon III: Buffoon, Modern Dictator or Sphinx? Edited by Samuel M. Osgood (Boston, 1963).

Blasio, José Luis Maximilian Emperor of Mexico: Memoirs of his Private Secretary José Luis Blasio. Translated from the original Spanish and edited by Robert Hammond Murray (Yale University Press, 1934).

Blayau,Noël Billault, ministre de Napoléon III d'après ses Papiers Personnels 1805 1863 (Paris, n.d.).

Blumberg, Arnold "French Government Justification for the Mexican Expedition, 18611867: A Study of Subtle Changes in the Management of Public Opinion Through Propaganda", Proceedings of Western Society for French History, Vol. 2, 1974, pp 292-301.

Bock, Carl H. Prelude to Tragedy: The Negotiation and Breakdown of the Tripartite Convention of London, October 311861 (Philadelphia,1966).

Bourne, Kenneth Britain and the Balance of Power in North America 1815-1908 (London, 1967).

The Foreign Policy of Victorian England 1830-1902. (London, 1970).

"The Clayton-Bulwer Treaty and the Decline of British Opposition to the Territorial Expansion of the United States, 1857-1860." Journal of Modern History Vol. 33, September 1961, pp. 287-291.

Bright, John and Rogers, James E. Thorold (eds) Speeches on Questions of Public Policy by Richard Cobden, M.P. (London,1878). 
Bury, J.P.T. Napoleon III and the Second French Empire (London,1975 (C) 1964).

Callcott, Wilfred Hardy Church and State in Mexico, 1822-1857 (New York, 1965 (C) 1926).

Campbell, Stuart L. The Second Empire Revisited: A Study in French Historiography (New Jersey, 1978).

Carr, Raymond Spain 1808-1939 (Oxford, 1975 (C) 1966).

Case, Lynn M. Edouard Thouvenel et la Diplomatie du Second Empire. Traduction française par Guillaume de Bertier de Sauvaigny (Paris, 1976).

(ed.) French Opinion on the United States and Mexico 1860-1867 (Archon Books, United States, 1969 (C) 1936).

Cavendish, Francis W.H. Society, Politics and Diplomacy 1820-1864: Passages from the Journal of Francis W.H. Cavendish (London,1913).

Chapelle, Count de la _Posthumous Works and Unpublished Autographs of Napoleon III in Exile (London, 1873).

Chevalier, Michel Mexico, Ancient and Modern.. Translated under the Author's superintendence by Thomas Alpass (London, 1864).

"L'Expédition du Mexique", La Revue des Deux Mondes, Vol. 38, 1 April, pp. 513-561, and 15 April 1862, pp. 879-918.

Cobden, Richard The Political Writings of Richard Cobden (London,1878).

Conway, Moncure D. "America, France and England", The Fortnightly Review, Vol 3, January 1866, pp 449-450

Corti, Egon Cæsar Count Maximilian and Charlotte of Mexico. Translated from the German by Catherine Alison Phillips (Archon Books U.S. 1968 (c) 1928).

Dabbs, Jack Autrey The French Army in Mexico 1861-1867 (The Hague, 1963).

Dawson, Daniel The Mexican Adventure (London, 1935).

Descola, Jean “L'Expédition du Mexique a Commencé aux Tuileries”, La Revue des Deux Mondes, No. 23, 1 December 1966, pp 341-359.

Dunaway, C.A. "Reasons for the Withdrawal of the French from Mexico", Annual Report of the American Historical Association 1902, Vol. 1, pp 315-328 (Washington, 1903).

Echard, William E. Napoleon III and the Concert of Europe (Baton Rouge, 1983).

d'Eudeville, Jean "L'Avènement du Second Empire et les Traités de 1815", Revue de Paris, Vol. 43 No. 17, 1 September 1936, pp. 96-110.

Ferrell, Robert H. Foundations of American Diplomacy 1775-1872 (Columbia, S.C. 1969).

Filon, Augustin Recollections of the Empress Eugénie (London,1920). 
Fleury, Général Comte Souvenirs du Général Cte Fleury, Vol. 2 (1859-1867)

(ed.) Memoirs of the Empress Eugénie, 2 Vols (New York, 1920).

Gaulot, Paul L'expédition du Mexique (1861-1867):D'après les documents et souvenirs de Ernest Louet, Payeur en Chef du Corps Epéditionnaire, 2 Vols (Paris, 1906).

Gérard,Alice Le Second Empire: innovation et réaction (Paris, 1973).

Girard,Louis Napoléon III (Paris, 1986)

Goetzmann, William H. When the Eagle Screamed: The Romantic Horizon in American Diplomacy 1800-1860 (New York, 1966).

Gorce, Pierre de la Napoléon III et Sa Politique (Paris, 1933).

Guedalla, Philip (ed.) Gladstone and Palmerston, being the Correspondence of Lord Palmerston with Mr. Gladstone 1851-1865 (London, 1928).

Palmerston (London,1950 @ 1926).

Guérard, Albert "Cæsarian Democracy" Napoleon III: Buffoon, Modern Dictator or Sphinx? Edited by Samuel M. Osgood (Boston, 1963).

"A Forerunner of Woodrow Wilson", Napoleon III: Buffoon, Modern Dictator or Sphinx? Edited by Samuel M. Osgood (Boston, 1963).

Guiral, Pierre and Témime, Émile "L'Historiographie du Second Empire", Revue d'Histoire Modeme et Contemporaine, Vol. 21, January-March 1974, pp. 1-17.

Hanna, A.J. and K.A. Napoleon III and Mexico: American Triumph over Monarchy (Chapel Hill,1971).

Haslip, Joan Imperial Adventurer: Emperor Maximilian of Mexico and his Empress (London, 1974 (C) 1971).

d'Hauterive, Ernest The Second Empire and its Downfall: The Correspondence of the Emperor Napoleon III and His Cousin Prince Napoleon. Translated from the French by Herbert Wilson (London, n.d.).

Hearnshaw, F.J.C. "The European Revolution and After; 1848-1854", The Cambridge History of British Foreign Policy, Vol. 2, 1815-1866, pp. 287-358.

Henry, Paul "Napoléon III et les Balkans", Napoléon III et l'Europe. Edited by Jacques de Launay (Brussels, 1965).

Hobson, J.A. Richard Cobden: The International Man (London, 1919).

Hoskins, Halford L. "French Views of the Monroe Doctrine and the Mexican Expedition", The Hispanic American Historical Review, Vol.4, 1921, pp. 677689.

Isser, Natalie The Second Empire and the Press: A Study of government Inspired Brochures and French Foreign Policy in Their Propaganda Milieu (The Hague, 1974).

Journal des Débats (Paris) 1861-1862, 1873. 
Kératry, Cte. Émile de "Le Mexique et les Chances de Salut du Nouvel Empire", Revue des Deux Mondes, Vol. 65, 15 September 1866, pp.442-461.

Lally, Frank Edward French Opposition to the Mexican Policy of the Second Empire (Baltimore, 1931).

Launay, Jacques de (ed.) Napoléon III et l'Europe (Brussels, 1965).

Lecaillon, Jean-François Napoléon III et le Mexique: Les illusions d'un grand dessein (Paris, 1994).

Lollié, Frédéric Rêve d'Empereur: le destin et l'âme de Napoléon III (Paris,1913)

Lousse, Emile "The True Place of Napoleon III in the History if Europe", Napoléon III et l'Europe. Edited by Jacques de Launay, (Brussels, 1965).

Mackay, Charles "The French Conquest of Mexico", The Westminster and Foreign Quarterly Review, Vol. 80, October 1863, pp. 313-344. pp. 232-244

McMillan, James F. Napoleon III (New York, 1991).

McPhee, Peter A Social History of France 1780-1880 (London, 1992).

Malmesbury, Earl of Memoirs of an Ex-Minister: An Autobiography (London, 1885).

Martin, Sir Theodore The Life of His Royal Highness the Prince Consort, Vol. 5, Third Edition (London, 1880).

Mazade, Charles de "L'Expédition du Mexique", La Revue des Deux Mondes, Vol. 37, 1 February 1862, pp.761-770.

"L'Expédition du Mexique", La Revue des Deux Mondes, Vol. 39, 15 May 1862, pp. 497-500.

"La Guerre du Mexique et les Puissances Européennes", La Revue des Deux Mondes, Vol. 40, 1 August 1862, pp. 733-761.

"La Question du Mexique dans le Parlement Espagnol", La Revue des Deux Mondes, Vol. 43, 15 January 1863, pp.505-512.

"Crise Ministérielle en Espagne", La Revue des Deux Mondes, Vol. 43, 15 February 1863, pp.1004-1008.

"La Paix Durable et les Publications Politiques", La Revue des Deux Mondes, Vol. 68, 15 December 1863, pp. 996-1005.

"L'Expédition du Mexique et la Politique Française", La Revue des Deux Mondes, Vol. 68, 1 December 1863, pp. 675-706.

"Le Général Prim", La Revue des Deux Mondes, Vol. 61, 15 January 1866, pp.540-544.

Mérimée, Prosper Lettres à Une Inconnue, Vol. 2 (Paris, 1893). 
Lettres à M. Pannizzi 1850-1870, 2 Vols. (Paris, 1881).

Metternich, Princesse Pauline de Souvenirs de la Princesse Pauline de Metternich (18591871) (Paris, 1922).

Motley, John Lothrop The Correspondence of John Lothrop Motley. Edited by George William Curtis, 2 Vols. (London, 1889).

Napoleon III Napoleonic Ideas Des Idées Napoléoniennes, par le Prince NapoléonLouis Bonaparte. Edited by Brison D Gooch (London, 1967).

Euvres de Napoléon III, 5 Vols. (Paris, 1869).

The Political and Historical Works of Louis Napoleon Bonaparte, President of the French Republic (London, 1852). Reprint NY, 1972.

History ofJulius Casar, 2 Vols. (Paris, 1865).

Nicolson, Harold T. The Congress of Vienna: A Study in Allied Unity : 1812-1822 (London, 1946).

O'Connor, Richard The Cactus Throne: The Tragedy of Maximilian and Carlotta (London, 1971).

Ollivier, Émile L'Empire Libéral, Vol. 3, Vol. 5, Vol. 6, Vol. 7, Vol. 9 (Paris, 1898. 1900, 1902, 1903,1904).

Journal 1846-1869, Vol. 2 (1861-1869). Text choisie et annoté par Theodore Zeldin et Anne Troisier de Diaz (Paris, 1961).

"Napoléon III: Son dessein international", La Revue des Deux Mondes, Vol. 146, 1 March 1898, pp. 49-84.

Osgood, Samuel M. (ed.) Napoleon III: Buffoon, Modern Dictator or Sphinx? (Boston, 1963)

Palm. Franklin Charles England and Napoleon III: A Study of the Rise of a Utopian Dictator (Durham N.C. 1948).

Palmerston, Viscount Opinions and Policy of the Right Honourable Viscount Palmerston as Minister, Diplomatist and Statesman, during more than forty years of public life (London, 1852) Reprint NY, 1972.

Parkes, Henry Bamford A History of Mexico (London, 1962 (C) 1960).

Patterson, R.H. “The Napoleonic Idea in Mexico", Blackwood's Edinburgh Magazine, Vol. 96, July, 1864, pp.72-83.

Persigny, Duc de Mémoires du Duc de Persigny (Paris, 1896)

Phelan, John Leddy "Pan-Latinism, French Intervention in Mexico (1861-1867) and the Genesis of the Idea of Latin America", Conciencia y Autenticidad Históricas (Mexico, 1968), pp. 279-298.

Pingaud, Albert "La Politique Extérieure du Second Empire", Revue Historique, Vol. 156, November/December 1927, pp. 41-68. 
Plessis, Alain The Rise and Fall of the Second Empire 1852-1871. Translated by Jonathon Mandelbaum (Cambridge, 1987).

Poulet-Malassis, A. Papiers Secrets et Correspondence du Second Empire, 2 Vols. (Paris, 1871).

Poulton,Gary M. Great Britain and the Intervention in Mexico, 1861-1865. Miami University Ph.D. 1976. Xerox University Microfilms, Ann Arbor (Michigan, 1982).

Reid, Rachel R. "The Franco-Italian War, Syria and Poland 1859-1863”, The Cambridge History of British Foreign Policy, Vol. 2, 1815-1866 (Cambridge, 1923), pp. 430-464.

Reinach, Joseph "Napoléon III et la Paix", Revue Historique, Vol. 36, January to April 1921, pp161-219.

Renouvin, Pierre Histoire Diplomatique 1815-1914: Cours de 1928-1929 (Paris,1929)

"Napoleon III, Bismarck, and Cavour", Napoleon III: Buffoon, Modern Dictator or Sphinx? Edited by Samuel M. Osgood (Boston,1963).

Reuter, Paul H. Jr. "United States-French Relations Regarding French Intervention in Mexico : From the Tripartite Treaty to Querétaro", The Southern Quarterly, Vol. 6 No. 4, July 1968 , pp. 469-489.

Richards, Edward W "Louis Napoleon and Central America", The Journal of Modern History Vol. 34 No. 2, June 1962, pp. 178-184.

Ridley, Jasper Maximilian and Juárez (London, 1993).

Robertson, William Spence "The Tri-Partite Treaty of London", The Hispanic American Historical Review, Vol. 20, No. 2, May 1940, pp. 167-189.

Roeder, Ralph Juarez and His Mexico, 2 Vols. (New York, 1947).

Russell, John Earl Recollections and Suggestions 1813-1873 (London, 1875).

Salomon, Henry L'Ambassade de Richard de Metternich à Paris (Paris, 1931).

"Le Prince Richard de Metternich et Sa Correspondance Pendant Son Ambassade à Paris (1859-1871), La Revue de Paris, NO 31 Vol. 1, 1924, pp. 507-541 and pp. 762-804.

Schefer, Christian La Grande Pensée de Napoléon III: Les Origines de l'Expédition du Mexique (1858-1862) (Paris,1939).

Schnerb, Robert Rouher et le Second Empire (Paris, 1949).

Senior, Nassau William Conversations with Distinguished Persons During the Second Empire, 2 Vols. Edited by M.C.M. Simpson (London, 1880).

Silberschmidt, Max The United States and Europe: Rivals and Partners (London, 1972).

Smith, William H.C. Napoleon III (London, 1972). Napoleon III: The Pursuit of Prestige (London, 1991). 
Sonolet,Louis "L'Agonie de l'Empire du Mexique d'après des lettres et des notes inédites du Général Castelnau", La Revue de Paris, Vol. 34, 1 August 1927, pp. 590-625 and pp. 862-898.

Le Temps (Paris), 1861-1867

Thompson, J.M. Louis Napoleon and the Second Empire (Oxford, 1965 (C) 1954).

Thouvenel, L. Le Secret de l'Empereur: Correspondance Confidentielle et Inédite Échangée entre M. Thouvenel, le Duc de Gramont, et le Général Comte de Flahault 1860-1863, 2 Vols. (Paris, 1889).

The Times (London), 1858-1864.

Tremenheere, J.H. "The Empire of Mexico", The Quarterly Review, Vol. 115, April 1864 , pp. 348-381.

Viel-Castel, Count Horace de Memoirs of Count Horace de Viel-Castel, 2 Vols. Translated and edited by Charles Bousfiels (London,1888).

Wellesley, Colonel the Hon. F.A. (ed.) The Paris Embassy During the Second Empire (London, 1928).

Whately, Archbishop Historic Doubts relative to Napoleon Buonaparte. Eleventh edition (London, 1852).

Williams, Roger L. "A Tragedy of Good Intentions", History Today, Vol. 4, No. 4, April 1954, pp. 219-226.

Zeldin, Theodore “The Myth of Napoleon III”, History Today, Vol. 8, 1958, pp. 103109. 


\section{Index of 12 ameg}

Almonte, General Juan. Mexican representative in Paris of Miramon Government.

Barail, General du. A Colonel in the Expeditionary force in Mexico.

Barrot, Odillon. French Minister in Madrid

Bazaine, General Achille François. Commander of Expeditionary forces from September 1863 until February 1867.

Bigelow, John. United States Ambassador to Paris 1865-1866.

Billault, Adolphe. Minister without portfolio 1861-1863.

Buchanan, Sir George. British Ambassador in Madrid

Castelnau, General Eduard de. Aidede-camp to Napoleon He was sent to Mexico by Napoleon in September 1866 to assess the situation of Maximilian's government and advise him to abdicate if he thought it necessary.

Challié, Captain de. Commander of the French frigate, La Foudre, and head of the French naval station near Mexico.

Chasseloup-Laubat, French Minister for Marine and Colonies.

Chevalier, Michel. Economic adviser to Napoleon and writer on American affairs.

Cobden, Richard. Eminent British politician who negotiated the Commercial Treaty between England and France in 1860.

Collantes, Calderon. Spanish Minister of Foreign Affairs.
Comonfort, Ignacio. Mexican President 1857-1858. Firstly a Liberal then a Conservative.

Corwin, Thomas. United States Ambassador to Mexico.

Cowley, Henry Richard Charles Wellesley. British Ambassador Paris 1852-1867.

Crampton, Sir John. British Ambassador in Madrid.

Degollado, General Santos. Officer in Juarez's army.

Doblado, General Manuel. Appointed Juarez's Chief Minister December 1861.

Douai, General Felix Charles. Second in command to General de Lorencez.

Drouyn de Lhuys, Edouard. Minister for Foreign Affairs from late 1862 .

Dunlop, Commodore Hugh. Joint British representative in Mexico with Sir Charles Wyke.

Estrada, Gutierrez de. Former Mexican Minister for Foreign Affairs, exiled in Europe since 1840, and leader of the delegation pressing for the establishment of a monarchy in Mexico.

Favre, Jules. One of Napoleon III's stongest opponents.

Flahault, Comte Auguste. French Ambassador to London 1861-

Fleury, General Émile Comte. Aidede-camp to Napoleon.

Forey, General Elie Frédéric. Commander of Expeditionary forces July 1862 to September 1863 . 
Frossard, General, Aide-de-camp to Napoleon who was sent to Vienna to encourage Maximilian to fulfil his commitment to go to Mexico.

Fuente, Juan Antonio de la. Mexican Minister in Paris for Juarez's government.

Gabriac, Comte de, French Minister in Mexico 1854-1860.

Gallifet, Captain Gaston-Auguste, marquis de. An officer in the army in Mexico who wrote to Napoleon privately about events in Mexico, having been a military aide-de-camp to Napoleon in 1860.

Gramont, Antoine Alfred, duc de. French Ambassador to Austria.

Guzman, Don Leon. Mexican Foreign Minister mid 1861.

Hammond, British Under Secretary of State for Foreign Affairs.

Hidalgo, José Manuel One of Mexican delegates exiled in Europe who claimed there was wide support in Mexico for a monarchy.

Isturiz, Spanish Ambassador in London 1861-

Juarez, Pablo Benito. Liberal President in Vera Cruz 1858-1860. President of Mexico from January 1861 after defeating Miramon.

Jurien de la Gravière, Admiral. Commander of the French expedition from November 1861 until the arrival of General de Lorencez.

Labastida, Archbishop Pelagio A. de. Archbishop of Mexico and a member of the Regency chosen to rule until the arrival of Maximilian.

Lavalette, Marquis de. French Minister for the Interior.

Lorencez, General Charles Ferdinand de. Commander of French Ex- peditionary Forces in Mexico March 1862 to October 1862.

Marquez, General. A Conservative who had continued to wage a guerrilla war against Juarez.

Mathew, George. Secretary of British Legation in Mexico City.

Mazade, Charles de. Lawyer and political observer of foreign policy and writer in journals such as $L a$ Presse and Revue des Deux Mondes.

Metternich, Prince Richard de, Austrian Ambassador to France.

Miramon, Miguel. President in Mexico City after Zuloaga 1860 January 1861 (Conservative Party).

Miranda, Padre Francisco. Representative of the Conservative Party.

Mon, Alesandro. Spanish Ambassador in Paris.

Montholon, French representative in Washington.

Le Noury, Vice-Admiral de la Roncière. From the Ministry of Marine and Colonies.

O’Donnell, Marshal. Spanish Prime Minister.

Ollivier, Emile. Formerly an Opposition member who later became Napoleon's Prime Minister.

Oseguera, Andrés. Mexican representative in Paris 1861.

Otway, British Minister in Mexico City prior to 1861 .

Pacheco, Joaquin Francisco. Spanish Minister in Mexico City.

Palmerston, Lord. British Prime Minister 1859-1865. 
Persigny, Victor Fialin, duc de. Minister in London 1860-1861, then Minister of the Interior.

Prim, General Don Juan Comte de Reus. Commander of Spanish contingent of allied expedition.

Randon, Marshal Jacques. Minister for War.

Rechberg, Count Johann Bernhard von. Austrian Foreign Minister.

Rollin, General. Adjutant-General of the Palace.

Rouher, Eugène. French Minister of State.

Russell, Lord John. British Minister of Foreign Affairs.

Saligny, Dubois de. French Minister in Mexico 1860-1863.

Santa Anna, Antonio Lopez de. President of Mexico for short periods from 1833 . Initially Liberal, he later became a Conservative.

Serrano, General Francisco. Spanish Captain-general in Havana.

Seward, William H. United States Foreign Secretary.

Thomasset, Captain. The French delegate who went to Mexico City to see Juarez in January 1862.

Thouvenel, Edouard. French Foreign Minister 1860-1862.

Valazé, Colonel. A member of the Expeditionary force in Mexico.

Wagner, Baron. Prussian Minister in Mexico.

Webb, General J. Watson. United States Ambassador to Brazil who was a friend of Napoleon III and had conversations with him in Paris in 1865 relating to the situation in Mexico.
Wyke, Sir Charles Lennox. British Minister in Mexico 1861-1862.

Zamacona, Manuel. Mexican Minister for Foreign Affairs from July 1861.

Zarco, Francisco. Mexican Minister for Foreign Affairs early 1861.

Zuloaga, Felix. President of Mexico 1858-1860 (Clerical-Conservative Party). 